\title{
А.С. ЖУЛЕВА
}

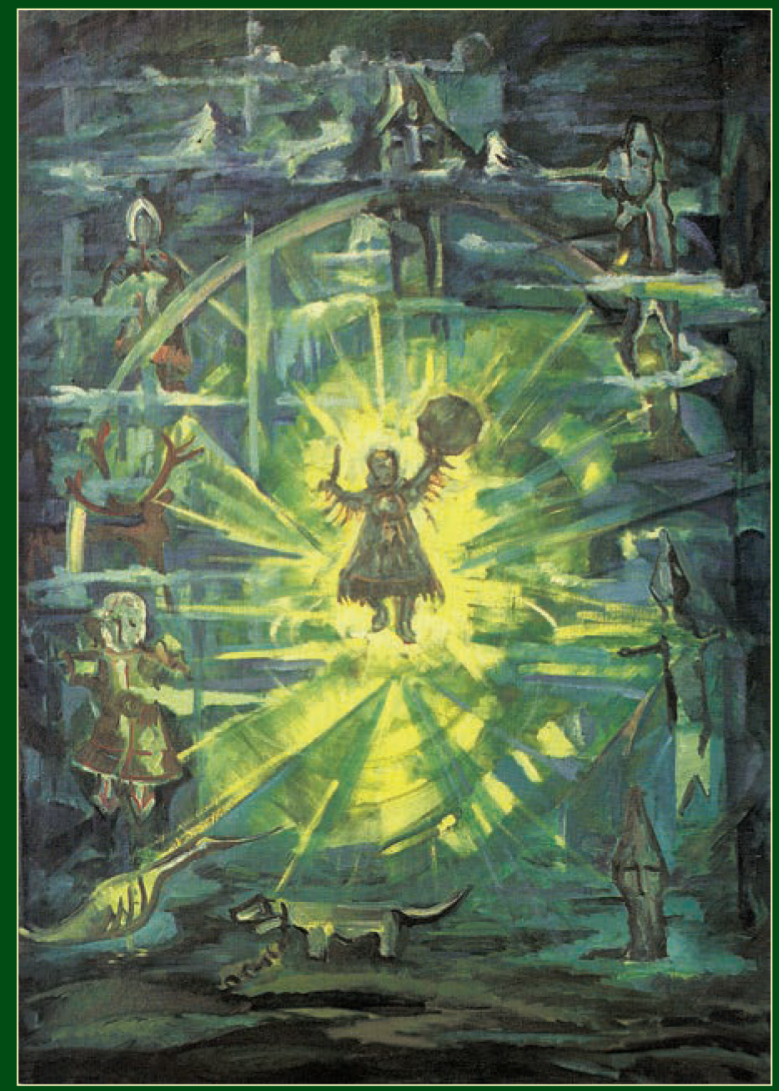

МИФОПОЭТИЧЕСКАЯ МОДЕЛЬ МИРА В НЕНЕЦКОЙ ЛИТЕРАТУРЕ 
Институт мировой литературы им. А.М. Горького РОССИЙСКАЯ АКАДЕМИЯ НАУК

\author{
А.С. Жулева
}

\title{
Мифопоэтическая модель мира в ненецкой литературе
}


ББК 83.3

Рецензенты:

доктор филологических наук А.И.Чагин

доктор филологических наук В.А.Бигуаа

А.С. Жулева. Мифопоэтическая модель мира в ненецкой литературе. М.: ИМЛИ РАН, 2019. - 328 с. - DOI: 10.22455/978-5-9208-0539-3

В книге представлен новый взгляд на мифологический пласт, заложенный в основу творческих кодов, художественного мира создателей уникальной ненецкой литературы в XX и в начале XXI веков.

В процессе построения мифопоэтической модели мира в ненецкой литературе осуществлена экспликация символов метафизических представлений народа о свойствах бытия и познания. Выявлено, как обладающие трансцендентной силой возвращения и воздействия первообразы, а также рожденные на их основе мифы и первичные представления о космосе, пространстве и времени, логосе, числах, о животном мире и окружающей природе реализуют свои значения в виде элементов текста: сюжетов, образов, мифологем и бинарных оппозиций.

Монография рассчитана на читателей, интересующихся литературой и культурой народов Севера, специалистов-филологов, студентов.

На обложке фотография картины «Духи Земли» ненецкого художника Леонида Лара. 


\section{ВВЕДЕНИЕ}

Мифопоэтическая модель мира вбирает в себя и мир как человека и природу в их взаимодействии, и модель мира как сокращённое отображение всей суммы представлений о мире внутри данной традиции и реализацию этой модели мира в различных семиотических воплощениях мифопоэтического сознания. Мифология является отражением триединой реальности, в которой пребывает человек: физической, метафизической и трансцендентной. Как исторический неосознанно-художественный тип мировоззрения мифология транслирует из древности в современность конкретно-чувственные образы и ассоциации, перцепции, отличающиеся своеобычной загадочной логикой. Мифологический материал для народов-мифотворцев был и формой самовыражения, и формой мышления, и формой жизни.

Мифы, воплотившие в символических формах процесс познания мира, обеспечили подлинное первоединство, «синтез мира и духа» (Гёте), обладают непреходящей силой и оказали изначально влияние на образный мир устного народного творчества, а позднее - на литературу; так в процессе развития постепенно установилась триада: миф - фольклор - литература.

Литература ненцев ${ }^{1}$ (устаревшие названия их «самоеды», «самоядь», «юраки») возникла вслед за письменностью в начале $\mathrm{XX}$ века. Свое активное развитие она получила во второй половине того же века и продолжает свою эволюцию в XXI. Литература ненцев самобытна и многожанрова - от рассказов до романов, от небольших стихотворений до поэм. Для создания характеристики мифопоэтической картины мира рассмотрены произведения разных периодов, в том числе плоды трудов зачинателей Тыко Вылки и Николая Вылки, Ивана Ного, а также их последователей (преемников): рассказы и романы, стихи Василия Ледкова, поэзия Леонида Лапцуя, Ивана Юганпелика, Алек- 
сея Пичкова, Прокопия Явтысыя, проза и поэзия Любови Ненянг, Юрия Вэллы, повести Анны Неркаги. Некоторые произведения были написаны и изданы на ненецком языке, другие - в переводе или в авторизованном переводе на русский язык, значительная часть написана и издана на русском языке, иные переведены и изданы на английском, финском, немецком и других языках.

Эстетические и нравственные искания авторов и героев, композиционные особенности произведений, содержание и поэтика произведений ненецких литераторов тесно связаны с мифологическими представлениями о мире, которые переплетаются с современностью. Мифологемы и бинарные оппозиции первозданного мира, рождающегося и развивающегося циклически, являются важнейшими составляющими их художественного мира. Первообразы и мифы знакомы литераторам чаще всего не из книг, не из чужой, а из своей собственной памяти, жизненного опыта, из своей «ночной» души, сновидений. Как форма синкретичного мышления ненцев, первообразы наполняются в литературе новым содержанием. Однако, как можно убедиться на основе текстологического анализа произведений, сохраняется не всегда понятная представителям современной дискурсивной культуры эмпатия, составляющая основу жизнедеятельности людей своеобычной культуры, в которой человек является не выделенной составной частью. «Выделенных» миров поначалу вообще нет. Мир един. И все, что населяет этот мир (вместе с самим человеком), - не отдельные выделенные (или альтернативные) миры, а сам этот мир. Все в нем равновелико человеку, и человек равновелик миру»².

С помощью мифов и обрядов, танцев, поддерживающих повествование действием, утверждались система ценностей и нормы поведения, что способствовало преодолению хаоса и создавало иллюзию возможности преодолеть стихийные силы природы. Миф как символ обладает действенной энергией, и в фольклоре и литературе народа становится, в зависимости от способа соотношения с другими смысловыми выразительными или вещественными формами, схемой, аллегорией, понимание которых зачастую осложнено, требует исторических и этнологических знаний.

Одна из задач проведенного исследования - раскрыть смысловую глубину связи трансцендентного с жизненным миром. Трансцендентное в жизненном опыте ненецких авторов и героев присутствует как эксплицитно, так и имплицитно, осуществляет себя чаще всего не опознаваясь в качестве такового, реализуясь 
то в роли имманентных мифологических персонажей, то в камланиях и заклинаниях шаманов, то в традиционных обрядах, ритуалах, а главное - в процессе коллективного и индивидуального взаимодействия с окружающей природой.

Не менее актуален и значим осуществлявшийся поиск решения других задач:

- выявить единое мировоззренческое основание, воплотившееся в поэтической концепции мира и человека, общее для писателей разных поколений, разных этапов формирования и развития ненецкой литературы;

- раскрыть знаковый характер восприятия и переживания собственной жизни авторов в биографической повседневности, историко-политической реальности, а также их героев в реалиях и фантазиях.

Поставленные задачи, направленные на формирование представлений о мифопоэтической модели мира в ненецкой литературе, определили концепт, в котором существенная роль отведена пространственно-временным представлениям и первообразам, Логосу, числовым кодам, зооморфным образам и шаманским верованиям.

Исследования мифа, его роли в фольклоре и литературе, формировании художественного сознания как зарубежных ученых (Дж. Фрэзер, К. Юнг, Н. Фрай, Ф. Шеллинг, М. Элиаде, К. ЛевиСтрос, Л. Леви-Брюль, Р. Барт), так и российских (В. Я. Пропп, Е. М. Мелетинский, В. М. Гацак, Г. Д. Гачев, А. И. Алиева и др.) способствовали определению истоков мифопоэтики литературы ненцев. Значительна роль в методологическом обосновании представленной мифопоэтической модели мира народа Севера работ литературоведов (М. М. Бахтин, Вяч. Иванов, А. В. Михайлов, В. В. Полонский, К. К. Султанов, Ю. Б. Борев, А. Ф. Кофман и др.). Труды фольклористов, этнологов, историков, созданные в разные годы и даже столетия, изучавших быт, традиции, верования, устное народное творчество северян (А. М. Кастрен, Т. В. Лехтисало, А. П. Окладников, В. Г. Богораз-Тан, Л. В. Беликов, М. Г. Воскобойников, Е. Д. Прокофьева, Л. В. Хомич, 3. Н. Куприянова и др.), позволили глубже раскрыть семантику мифологем, образов и сюжетов, специфику художественного вымысла авторов. В процессе исследования проанализированы также работы североведов А. В. Пошатаевой, Б. Л. Комановского, Ю. Г. Хазанкович, О. К. Лагуновой. Ообое внимание уделено исследованиям ненецких ученых А. П. Пырерки, Е. Т. Пушкаревой, Е. Г. Сусой, материалам художника и фольклориста Л. А. Лара. 
При определении методологии исследования мифологического мировосприятия, отраженного в ненецкой литературе, был реализован комплексный подход, соединяющий мифопоэтические и жанрово-системные приемы анализа содержательных аспектов произведения и интерпретации, историко-генетический, компаративистский, герменевтический и биографический методы. Применение комплексного подхода, использование мифопоэтических и жанрово-системных приемов анализа художественного произведения в сочетании с герменевтическим, биографическим, компаративистским методами продиктовано необходимостью осмысления ненецкой литературы в контексте истории развития духа, мышления, художественного сознания, культуры, а также актуальностью, значимостью для раскрытия темы, для эффективного поиска ответа на вопрос о сходстве и различии в мировидении с другими народами циркумполярного (арктического) региона, находящимися в едином историко-литературном пространстве. Актуальными представляются в процессе использования приемов компаративистики идеи Н. Фрая об изначальной связи поэтических ритмов с природным циклом «через синхронизацию организма с природными ритмами».

Представить (восстановить) мифопоэтическую модель мира ненцев на основании художественных произведений невозможно без привлечения разнообразных источников - мифов, фольклора и эпоса, языковых данных, сведений по этнографии и этнологии, истории народа, а также материалов о традиционных представлениях в сознании современного человека.

Мифопоэтическое художественное сознание, именуемое некоторыми исследователями (например, Г. Гачевым) бессознательно-художественным, в письменной литературе ненцев развивалось стадиально, постепенно изменялся характер использования мифологического, фольклорного материала, который поновому трансформировался, вписывался в сюжет, в рождающуюся действительность вымысла, материализовался в сферу отношений, переносился во внутренний мир героев. В связи с этим, было существенно обозначить подходы к таинственной проблеме преобразования мифологической парадигмы по мере исторического развития ненцев, отражения ее в фольклоре, в эпических песнях сюдбабц и ярабц, а потом и в творческом сознании создателей письменной ненецкой литературы, выявить, как трансформируется смысловая составляющая мифа в образах, мотивах и сюжетах. 
Мифы, мифические песни, мифические сказки, этиологические сказки, насыщенные мифопоэтикой героические песни легли в основу письменных творений ненцев. Исследуя жанровый генезис, Е. М. Мелетинский писал о постепенно установившейся в процессе развития триаде: миф - фольклор - литература, подчеркивал важность разграничения мифа и сказки в архаической культуре, поскольку «первобытные» сказки еще сами не отпочковались от мифов и мифологизированных «быличек», обосновал критерии разграничения, отмечая, что «сказка обычно трактуется как чисто художественное, а в мифе неразличимы элементы бессознательно-поэтические, зачатки религиозных и донаучных представлений, часто имеются следы сходные с ритуалами» ${ }^{3}$. Руководствуясь установками Е. М. Мелетинского, при рассмотрении проблемы разграничения мифа и сказки в фольклоре ненцев Е. Т. Пушкарева отметила отсутствие отдельных названий для мифа и сказки или нечеткое именование текстов лаханако или хэбидя лаханако и сделала вывод, что это явление свидетельствует - «сказка еще не отделилась от мифа» ${ }^{4}$.

Произведения ненецких авторов наполнены фантастическими мифологическими образами. Фантастический дискурс как вид художественного дискурса отражает модели реальности, связанные с мифическими и сказочными образами, мотивами, сюжетами. Устремленность воображения ненецких авторов в запредельный мир мифов, легенд, эпических песен-сюдбабц и ярабц может иметь и метафизическое обоснование. По словам Юнга, писатель - это реагирующий объект (а не субъект), а художественное произведение есть некое живое существо, которое пользуется автором как своим рупором. На вопрос, предложенный психологом: «Я мыслю или мне мыслится?»- не может дать точный ответ ни один творец, тем более из числа тех, для кого мифологический образ мышления его народа близок, присущ в той или иной степени и самим писателям и поэтам. Если опереться на гипостазийный подход, то можно предположить бессознательное воздействие животворящей силы мифа на их творческий процесс.

Созданию лирических стихотворений во многом способствовал как героический эпос, так и личные песни как возможность подняться над собой, преодолеть свою непосредственную субъективность, увидев себя со стороны. Эпос и лирика имеют право называться объективированным воспроизведением душевных переживаний, учитывая, что человек возможен как таковой бла- 
годаря абсолютно «Иному» (Ясперс), который и может оценить происходящее.

Мироосмысление и самоопределение человека, обеспечивающие самоидентификацию и преемственность национальной картины мира, тесно связаны с онтологией сотворения мира. Возникшее в древности антропоморфное моделирование космического пространства, неодушевлённых объектов в образных системах, в бытовых сферах определяется философами как необходимость уйти от первоначальной целостности и нерасчлененности человеческой деятельности и, возможно, было порождено грезами, воображением еще до всякой культуры. Фантазией наполнены, например, мысли французского философа Г. Башляра о том, как мифы, «выходя из земли, разверзали озера для того, чтобы земля, очами озер, гляделась в небо. Предопределенные безднами вздымались вершины. Мифы сразу же находили человеческие голоса, обретали человеческий голос, грезящий о мире своих грез. Человек выражал землю, небо, воду. Человек был словом этого макроантропоса - чудовищного тела земли. В космических грезах земли мир был телом человека, смотрел глазами человека, дышал грудью человека, говорил голосом человека» ${ }^{5}$.

Понять мифологический мир ненецких поэтов и прозаиков непросто не только из-за отсутствия знаний мифологии народа, но еще и потому, что творцы чаще всего не просто пересказывают миф, а трансформируют его или дают лишь один определенный штрих. Метафоры приобретают особое звучание, содержание мифов стилизуется или на их основе создаются новые мифы.

Предваряя определение архетипов, Юнг выразительно представил значимость мифологии: «Мифология, подобно отсеченной голове Орфея, продолжает петь даже после смерти, и пение ее доносится издалека. В то время, когда мифология была неотъемлемой частью жизни народа, ее не просто исполняли как некий вид музыки, ею жили. Мифологический материал для народов-мифотворцев был и формой самовыражения, и формой мышления, и формой жизни» ${ }^{6}$.

Существуют различные предположения о причинах укорененности мифологических представлений в национальном подсознании. Возможно, сила воздействия мифа, знаков-вымыслов, значения которых были отражением окружающего мира и сакрализовали его, а также выполняли разные функции, в том числе устанавливали нормы поведения, скрывается в его коммуникативной природе, беспредельной «суггестивной силе слова» 
(Р. Барт), в изначальной авторитарности. По мнению ученого, «игра в знаки» (сознательная мистификация) завораживала, становилась «джокером всякого дискурса» ${ }^{7}$.

Миф, как и мифологизированное «историческое» предание, совмещает в себе два аспекта - диахронический (рассказ о прошлом) и синхронический (средство объяснения настоящего, а иногда и будущего). Эта неразрывная двуединая связь диахронии и синхронии - неотъемлемая черта мифопоэтической модели мира.

Постижение истоков бинарных оппозиций и мифологем в произведениях ненецких авторов предопределило обращение к размышлениям философов и этнологов о «неприрученных мыслях» (Леви-Строс). Исследователь структурной антропологии Леви-Строс определял миф и порождающее его первобытное мышление как логический инструмент противоречий, необходимый для ликвидации или смягчения существовавших разрывов в понимании бытия, поскольку, по его мнению, изначально человек воспринимал окружающий мир как комплекс противоположностей, противоречий, требовавших своего познавательного и мировоззренческого разрешения.

Выражая мироощущение и миропонимание человека, миф затрагивает все волнующие человека коренные вопросы мироздания, метафизическую и онтологическую связь с природой и животным миром. Мир мифа эмоционален и драматичен. Эстетика мифа - имагинативное бытие. Возможно, сила его воздействия на формирование художественного сознания кроется в существовании единого для мифов и литературного творчества неопределимого синкретичного закона имагинации, воображения.

В первой главе рассмотрены важные аспекты художественного мира - пространство, время и хронотоп (греч. chronos время, topos - место), обозначающий существенную взаимосвязь временных и пространственных отношений, художественно освоенных в литературе. Обоснован раздельный подход к пространственным и временным категориям в произведениях, определенный спецификой как самой темы, связанной с мифологией, традициями, ритуалами, так и с особенностями традиционного художественного мышления ненецких авторов и героев. Уделено также внимание определению значимости хронотопа в развитии сюжетов, мотивов, создании образов.

В числе основополагающих в содержании главы стали философские исследования О. Шпенглера, определявшего значимость 
художественного пространства не только для индивидуального восприятия, но и для культуры в целом и для всех видов искусства, существующих в рамках конкретной культуры, выводы историка Л. Н. Гумилева о том, что реальное регионально-географическое пространство откладывает неизбежный отпечаток на ментальность этноса, формируя психологический облик его представителей, этнокультурные и онтологические характеристики, мысли, идеи о пространственно-временном континууме М. Бахтина. Нашли отражение результаты исследований о художественном пространстве текста Р. Барта, В. Н. Топорова, Ю. М. Лотмана, Ю. Б. Борева.

Для создания одной из составляющих модели мифопоэтической картины мира - пространственных представлений - акцентировано внимание как на космизме в ненецкой литературе, в том числе на трансформации мифологем и концепта круга; на характеристике тундры, ее простора как самовластного и покоряемого топоса, так и на выявлении роли звуков как части природного пространства и ориентира в нем; на значимости профанных и сакральных пространств быта ненцев - стойбище и чуме; на определении гендерной специфики художественного пространства.

Ненецкие писатели и поэты в своих произведениях проецируют внутренние, рожденные в глубине сознания и души традиционные мифологические формы и образы пространства в поэтику художественного пространства, помогая читателю проникнуть на уровень подсознательного, в психологию персонажей, а также самих авторов.

Процесс освоения ненецкими прозаиками и поэтами категорий художественного времени и вечности, формы хронотопа детерминирован мифологией, этнической культурной традицией, спецификой зарождения и истории этой северной литературы.

Поскольку художественное сознание ненецких авторов вырастало из бессознательного мифопоэтического мышления, в нем проявляются представления не только об упорядоченном, линеарном историческом времени, но и о циклическом, мифическом времени.

Миф не относится к определенному времени. Это - постоянно повторяющаяся история, вечно существующее «возобновляющееся» происшествие, как и те ритуальные празднества, с которыми связан миф. Основанием мифа является повторение - «пульсация». Время связывается с физическим телом. Особенно ярко это проявляется в своеобычном хронотопе шаманизма. 
Столкновение мифологического и линеарного представлений о времени, традиционного и нового осознания пространства в произведениях определило фабулу многих произведений, в частности повестей Анны Неркаги. Так, конфликт между главными героями повести «Анико из рода Ного» обостряется столкновением двух типов мировосприятия, двух хронотопов. Анико живет в современном, типичном для жителей города ритме, где время определяется общепринятым метрическим измерением. Оно насыщено разнообразными событиями, связанными с занятиями в институте, с работой, развлечениями. По утверждению повествователя, мысли о том, что можно будет съездить к родителям и «получить прощение за то, что в жизни по-прежнему много суеты и мало времени для любви», посещают ее редко, но, появившись, успокаивают, снимая ответственность перед родителями. Отец героини оленевод Себеруй и жители ее родового стойбища живут по законам мифического циклического времени, меняя два раза в год место проживания, чтобы обеспечить себя пропитанием, продолжить жизнь рода.

Как ненецкие, так и хантыйские, чукотские авторы наделяют героев особой чувствительностью к «колебаниям времени», отмечают, что каждое время у них имело свою окраску - темную или светлую. Отсчет времени обычно начинался с какого-либо значительного события. Прошлое для героев - это не обилие цифр вроде тысячелетий или веков, а конкретные события, деяния определенных людей, предков, прожитая ими жизнь.

Вторая глава посвящена золотому звену в цепи, соединяющей времена, - художественно развернутым в ненецкой литературе символическим первообразам (архетипам) восприятия окружающего мира и себя в нем как ненцами, так и другими народами Севера. Существенно обращение к истокам - стадиальному развитию первобытного мышления, о двух стадиях которого - тотемистической и космической - писали в начале $\mathrm{XX}$ века академик Н. Я. Марр и французский философ и этнолог Л. Леви-Брюль.

Сконцентрированное внимание к первообразам, идеям, которые стали из незримого порождения сознания видимыми образами, образцами поведения, - путь не только к открытию новых смыслов в художественных текстах, но и к постижению мировидения героев, к прояснению поступков и поведения их. Вычленение архетипов из имеющихся в произведениях символов, мотивов, мифологем позволило раскрыть не только фольклорно- 
мифологическую основу, но и историко-культурный контекст, индивидуальное своеобразие творцов.

В литературе ненцев «коренные понятия человечества» как составляющая мифов, мифов-сказок актуализированы на уровне сюжетно-композиционных сближений, явных или скрытых цитат, реминисценций, аллюзий, сознательных вариаций и других форм влияния.

Мифологизированное мышление северных народов хотя и было коллективно-бессознательным, но, судя по фольклору и литературе, обладало логической гибкостью и метафорическим богатством. Только обобщения, классификация и анализ могли породить такие своеобразные знаковые системы родства, связи с природой. Бинарные оппозиции в классификациях и обобщениях северян - свидетельство богатства логических возможностей их сознания, метафорических трансформаций.

Постигая с помощью расшифровки (скорее - разгадывания) символики первообразов северян, мы погружаемся в особый мировоззренческий мир, наполненный специфическими символами, жизнеутверждающими образами. Общие для всех культур оппозиции: свет и тьма, добро и зло, радость и горе, поддержка и равнодушие, красота и уродство и другие пронизывают их восприятие космоса, земных стихий, в то же время наполнены специфическим для бытия северян особенностями.

Логос - первообраз и первоисточник, создающий гармонию мира и активно участвующий в творческом литературном процессе. Среди мифологических и фольклорных первообразов, нашедших свое отражение в ненецкой литературе, выделены - слово-песня, слово-сказка. Вездесущая Песня-Мынико (слово-песня) в поэме Лапцуя «Тёр» появилась раньше других действующих лиц, став для них невидимой героиней. В главе нашла отражение попытка найти подходы к раскрытию творящей природы слова, Логоса, его роли в переходе сознания от хаоса к космосу, в формировании первообразов и художественного сознания.

Глава «Зооморфные мифологические образы» содержит материал о зооморфной семантике в литературе ненцев, направленный на выявление зооморфных мифологем, определение роли зоонимов в развитии сюжетов, мотивов, создании образов, наряду с другими художественными приемами, что также дает возможность реконструкции древних представлений народа об устройстве мира. Раскодирование же зооморфных образов в литературе возможно лишь в контексте с данными, накопленными не 
только мифологией и фольклором, но и этнографией, археологией и другими науками. Так, известный археолог и этнограф А. П. Окладников, исследовавший древнюю культуру народов европейского и азиатского Северо-Востока, в работе «Утро искусства» писал о широком распространении олицетворения стихии природы, неба и земли в виде живых существ, о наделении их сознанием, чувствами и волей, предполагал, что были эти «живые олицетворения стихий природы, даже самой Вселенной, скорее всего, зооморфные». Развивая мысль о возникновении зоопатрических культов, В. Н. Топоров предположил, что именно животные могли использоваться как модель жизни человеческого общества и природы в целом (прежде всего в аспекте плодородия и цикличности), поскольку служили для человека в течение длительного времени «некоей наглядной парадигмой». Он утверждал, что в мифологическом сознании животные выступают как один из вариантов мифологического кода. Символические образы животных в ненецкой народной традиции связаны как с видовыми особенностями животных, так и со специфическим характером жизнедеятельности народа. Используя и обновляя мифические и сказочные образы, мотивы, сюжеты в сочетании с жизненным материалом истории и современности, поэты и прозаики расширили познавательное поле ненецкой культуры. Выявление же коннотативных значений культурных кодов в их произведениях позволяет обнаружить специфику мировидения народа, а также раскрыть (приоткрыть) суть авторской программы самовыражения.

Составить представление о числе как коде культуры ненцев в процессе комментария мифов, эпоса, фольклора и литературы в контексте духовно-национальных воззрений - задача не из легких, но в ходе исследования сделана попытка приблизиться к ее решению.

Для того чтобы установить, какой тайный смысл вложил тот или иной автор в свою игру цифр, в главе «Число как код мировидения ненцев» осуществлен поиск следов мифопоэтической концепции числа, его «качественных» свойств, рассмотрен символизм чисел в мировоззренческих установках ненцев и других народов, в первую очередь, народов Севера. Выделена роль финского исследователя Матиаса Александра Кастрена, впервые выдвинувшего предположение о существовании в древности у всех самодийских народов, к которым относятся и ненцы, семиричной системы счета. Число семь как завершающее семиричную 
систему счета ненцев, судя по мифологии, фольклору и литературе, обладает особой значимостью, наделено высокой степенью сакральности. Появление же современной десятичной системы счета у ненцев этнолог Л. В. Хомич связывает с развитием торговли и обмена с русскими, утверждая, что до этого была еще и девятиричная система отсчета. Потому, по ее мнению, число десять по-ненецки называется «луца ю» - русский десяток.

При рассматривании числа как фактора, обусловливающего своеобразие восприятия окружающего, фактора осмысления мира, в главе мы наиболее тщательно эксплицировали некоторые первые числа, входящие в семиричную систему счета: 1, 2, 3, 4, 7. Основное внимание направлено на то, какой смысл сознательно или бессознательно вкладывали ненцы в числовые обозначения, кроме количественного обозначения, в мифах и фольклоре, как трансформировали традиционную нумерологию писатели.

Тесно переплетающийся с мифологией шаманизм - религиозное верование у ненцев и других северных народов, - являющийся частью мировидения авторов и героев, рассмотрен в главе «Мифопоэтика и мир шаманов». По мнению Мирче Элиаде, арктические народы, в отличие от многих других, хотя и ощутили влияние извне, не утратили после этого собственной структуры шаманизма и сохранили термин шаманизм «в строгом смысле». Художественная семантика произведений ненецких поэтов и прозаиков пронизана шаманизмом как особой системой мировоззрения, включающей в себя элементы рационального, иррационального и образного познания мира. Шаманизм нашел свое яркое отражение в формировании художественного сознания ненецких литераторов.

В пьесе драматурга Ивана Ного «Шаман», в поэме «Тёр» и стихах Леонида Лапцуя, в поэзии Прокопия Явтысыя, Алексея Пичкова, Ивана Юганпелика, в стихах Василия Ледкова и в его дилогии «Месяц Малой Темноты», в повестях Анны Неркаги «Анико из рода Ного», «Илир», «Белый ягель», «Молчащий», в стихах и прозе Любови Ненянг, в произведениях других авторов представлены как шаманские образы, так и мировоззренческие установки героев и нарраторов, возникшие под влиянием идей шаманизма.

В процессе анализа уделено внимание развитию и отражению культа духа политеизма, жертвоприношениям как мистическому освоению мира, а также семиотике камлания, подготовке и посвящению в шаманы. 
В шестой главе представлен материал о двух творцах мифа Нового времени. С опорой на биографический метод определена значимость для освоения мифопоэтики произведений обращения к биографиям и автобиографиям создателей. Согласно концепции М. М. Бахтина, произведения становятся самовыражением «я» автора, его поступков, которыми писатель со-бытийствует с окружающим миром, вступает с ним в диалог. На примере жизни и творчества двух поэтов - Леонида Лапцуя и Юрия Вэллы (Айваседы) сделана попытка раскрыть своеобразие их художественного восприятия мира, «ролевого «жизнетворчества», ставилась задача выявить возможное сходство поэтических миров двух поэтов, имевших общие мифологические истоки. В главе «Творцы мифа нового времени» превалирует убеждение, что индивидуальные мифы личностей обеспечивают жизнеспособность как литературного процесса, так и культуры в целом, становятся важным звеном в их развитии и обновляемости. Оба поэта были носителями мифологического сознания, тонкими знатоками этнокультуры, постоянно обращались к памятникам народного творчества. В кабинете музея-квартиры Лапцуя, автора более двадцати книг на ненецком и русском языках, немало фольклорного материала, собранного и обработанного им (напечатанного на страницах газет, журналов, сборников) и ещё не представленного читателям. Поэтические мотивы, сюжеты, образы ненецкого устного народного творчества в произведениях Лапцуя получили свое развитие в описании как прошлого этноса, так и современности, эволюционировали в содержании произведений. Творчество Лапцуя пропитано мифопоэтикой - унаследованными схемами, концепт-образами, как и произведения Юрия Вэллы. Представитель лесных ненцев Вэлла (Айваседа) создал два музея, две школы, постоянно собирал фольклор, материал для топонимического словаря под рабочим названием «Река Аган с притоками», который был издан в Ханты-Мансийске в 2010 и 2012 годах. Юрий Вэлла писал на ненецком, хантыйском и русском языках. Общественная деятельность Айваседы была постоянно направлена на сохранение экологии, возрождение культурных ценностей как своего народа, так и народов-соседей ханты. Владевший хантыйским языком, собиравший фольклор не только ненцев, но и хантов, Вэлла обрабатывал его художественно и помещал в книги как на хантыйском, так и на русском языках. Для Вэллы в большей степени, чем для Лапцуя, была свойст- 
венна мифологизация национального образа жизни, поскольку «пришли другие времена», появились иные возможности.

Явленный литературой ненцев и другими литературами народов Севера образносозидающий мир традиционных воззрений убедительное свидетельство влияния мифологических представлений на формирование эстетических и этических законов бытия, на развитие художественного сознания.

${ }^{1}$ Ненцы - устаревшее название самоеды, юраки. По итогам переписи 2010 г. их около 45 тыс. человек. Проживают в Ненецком округе Архангельской области, в Ямало-Ненецком округе Тюменской области и в Таймырском (бывшем Долгано-Ненецком) округе Красноярского края.

${ }^{2}$ Андреев Д. Роза мира. Метафилософия истории. М., 1991. С. 86.

${ }^{3}$ Мелетинский Е. М. Миф и сказка // Фольклор и этнография. Л.: Наука, 1970. C. 139.

${ }^{4}$ Пушкарева Е. Т. К проблеме разграничения мифа и сказки в фольклоре ненцев // Фольклор и этнография народов Севера. Межвузовский сборник научных трудов. Л., 1986. С. 54.

${ }^{5}$ Башляр Г. Вода и грезы. Опыт о воображении материи / Пер. с франц. M., 1998.

${ }^{6}$ Юнг К. Г. Душа и миф. Шесть архетипов / Пер. с. англ. Киев, 1996. С. 3.

${ }^{7}$ Барт Р. Избранные работы: Семиотика. Поэтика / Пер. с фр. М., 1989. C. 73. 


\section{Глава 1}

\section{ПРОСТРАНСТВО И ВРЕМЯ}

Мифопоэтическая модель мира, тесно связанная с преобразованием хаоса в космос, с пространственно-временным континуумом, предполагает выявление и описание издревле существовавших у ненцев представлений о нем, трансформированных в мифах, фольклоре, эпосе, литературе, которые отразились на формировании авторской картины мира. Эти самобытные укорененные представления насыщали произведения художественнозримыми образами, участвовали в развитии мотивов, ситуаций, в композиционном построении. Хронотоп, обозначающий существенную взаимосвязь временных и пространственных отношений, художественно освоенных в литературе, нашел свое должное место в работе. Однако, особенности развития ненецкой литературы, специфика раскрытия темы, связанной с мифологией, традициями, ритуалами, определили использование раздельного подхода в описании художественного пространства и времени, выделение на первое место пространства. Немаловажную роль в выборе и обосновании подхода сыграли идеи Ю. Б. Борева об особенностях художественного мышления в древности. Характеризуя художественный процесс на основании параметра пространство и время, исследователь в «Эстетике» ${ }^{1}$ предложил свой тип деления, раскрыл, как искусство на разных стадиях развития сосредоточивало внимание на тех или иных аспектах художественного мира - на пространстве, на времени или на времени-

пространстве. Так, древнее искусство, по его мнению, мыслило преимущественно пространством, поскольку главной его темой и проблемой был миропорядок. Человека занимали вопросы космогонии, происхождения Вселенной, богов, духов, покровительствующих разным сферам жизни и деятельности. Мыслить же пространством и временем в их единстве начинает лишь ис- 
кусство, сформировавшееся в XIX и XX вв. Следует отметить, что именно на рубеже этих веков математик Герман Минковский, физик Эйнштейн, биолог А. Ухтомский предложили рассматривать пространство и время в единстве: Минковский называл время-пространство или пространство-время, Эйнштейн назвал это соединение пространственно-временным континуумом, Ухтомский - хронотопом. М. Бахтин, ссылаясь на «Трансцендентальную эстетику» И. Канта и на доклад А. А. Ухтомского 1925 г., обосновал возможность осваивать взаимосвязь временных и пространственных отношений в литературоведении, назвав ее хронотопом (дословный перевод времяпространство). Он писал в работе «Формы времени и хронотопа в романе»: «Приметы времени раскрываются в пространстве, и пространство осмысливается и измеряется временем. Этим пересечением рядов и слиянием примет характеризуется художественный хронотоп» ${ }^{2}$. Исследователь на примере анализа античного романа определил, что хронотоп играет важную роль в жанрообразовании и характеризует жанр, определяет свойства героя, а также художественное единство самого произведения и его отношение к реальной действительности. Он предполагал возможность использования хронотопа в литературоведении, хотя сам на практике уделял больше внимания времени, чем пространству.

Рассматривая мифологический аспект пространственно-временной картины мира в литературе ненцев, остановимся в первую очередь на традиционных пространственных ориентирах, символах.

\section{Лики пространства}

Философско-эстетическая категория пространство - важнейшая составляющая художественного мира писателя и его произведений. Многоликое пространство - видимое и недоступное визуальному восприятию, физическое и трансцендентное, концептуальное и ассоциативное - «является частью реального пространства и организовано как некоторое единство именно в нем» ${ }^{3}$. По словам Ю. М. Лотмана, «в художественной модели мира "пространство" подчас метафорически принимает на себя выражение совсем не пространственных отношений в моделирующей структуре мира. Таким образом, художественное пространство представляет собой модель мира данного автора, выраженную на языке его пространственных представлений». 
Он утверждал также, что «язык пространственных представлений» в литературном творчестве «принадлежит к первичным и основным». В статусе важной категории поэтики пространство выступает в литературе и как текстопорождающий механизм, и как смысловое образование, имеющее символическую природу.

Ненецкие писатели и поэты в своих произведениях проецируют внутренние, рожденные в глубине сознания и души традиционные мифологические формы и образы пространства в поэтику художественного пространства, помогая читателю проникнуть на уровень подсознательного, в психологию персонажей, а также самих авторов. В связи с этим, исследуемая своеобычная литература северного народа позволяет реконструировать этнографические субстраты, с одной стороны, а с другой - способствует постижению онтологических и феноменологических основ, связей, реминисценций культуры, раскрывает специфику материальной и духовной жизни ненцев, ценности, определяющие поведение и характер, их миропонимание.

Обосновывая исторические корни общности духовной культуры народов Севера, А. В. Пошатаева писала о тесной связи художественных форм их духовной культуры с материальной, о единении с природой, которое расширяло диапазон поэтического восприятия жизни. В своей книге «Литературы народов Севера» $(1988)^{4}$ Алла Владимировна анализировала истоки, стадии формирования самобытных литератур, отмечала, что в произведениях нашли отражение художественно-пространственное видение и конкретизация его в устнопоэтических структурах, созданных фольклорно-мифологическим сознанием. Разрабатывая концепцию художественного пространства, автор этого термина О. Шпенглер в «Закате Европы» ${ }^{5}$ подчеркивал важность пространства и для индивидуального восприятия и для культуры в целом. Мифы, традиции, архетипы опираются на своеобычные пространственные представления этноса и делают культуру отличающейся от любой другой.

Пространственная ориентация часто манифестируется в трех типах: реальное пространство, концептуальное пространство (культурное, социальное, религиозное и т. д.), пространство ассоциативного фона события - ассоциативное. В художественных текстах порой наиболее значимо пространство отношений - метафизическое.

Реальное пространство, представленное в ненецкой литератуpe, раскинулось географически широко, по местам проживания 
ненцев. Это тундра и тайга, Баренцево и Карское моря, многочисленные озера и реки, в их числе Печора, Обь и Енисей, мелкие и крупные острова, среди которых Новая Земля, полуострова Ямал и Таймыр. В этом многоликом и жестком северном пространстве раскрываются формы природного бытия и человеческого обитания. Именно оно наполняется реальным жизненным смыслом и получает существенное отношение к герою и его судьбе.

Художественное пространство является преобразованным пространством действительности, имеющим эстетический смысл и содержание, поэтому и актуальны вопросы определения пространства, явленного в тексте, способов его описания. Пространственные характеристики в литературе ненцев играют существенную роль в структурно-содержательной организации произведений. Пространство в произведениях выступает в разных ипостасях:

a) средство композиционного построения; б) прием организации действий и поступков героев; в) для характеристики действующих лиц; г) для художественного представления о реальной действительности; д) для понимания специфики мировидения ненцев.

Анализируя поэтику художественного пространства отдельных произведений ненцев, остановимся

- на некоторых теоретических предпосылках, различных подходах к постижению пространственных концепт и мифологем;

- на космизме в ненецкой литературе, в том числе на трансформации мифологемы мирового древа и концепта круга;

- на характеристике тундры, ее простора как самовластного и покоряемого топоса;

- на выявлении роли звуков как части природного пространства и ориентира в нем;

- на значимости профанных и сакральных пространств быта ненцев - стойбище и чуме;

- на определении гендерной специфики художественного пространства литературы ненцев.

\section{Художественный текст и художественное пространство}

Рассуждая о литературоведческом объекте «художественный текст», его восприятии, философ и литературовед Роберт Барт выделял символичность и считал, что текст - это произведение, понятое, воспринятое и принятое во всей полноте своей символической природы. Логика, регулирующая текст, по его мнению, 
основана не на понимании, «что значит» произведение, а на выработке ассоциаций, взаимосцеплений, переносов, где находит себе выход символическая энергия. Присущая тексту смысловая множественность вызвана прежде всего «пространственной многолинейностью означающих», из которых он соткан (В. Н. Топоров). Пространство, соотносимое с миром художественного произведения, интерпретируется по-разному. В. Топоров, анализируя соотношение пространства и текста, определил «два логических полюса этого соотношения: текст пространственен (т. е. он обладает признаком пространственности, размещается в “реальном пространстве", как это свойственно большинству сообщений, составляющих основной фонд человеческой культуры) и пространство есть текст (т. е. пространство как таковое может быть понято как сообщение)» ${ }^{6}$.

В своих исследованиях В. Топоров опирался на философские исследования О. Шпенглера, который, размышляя над проблемами пространства искусства, изложил в книге «Закат Европы» концепцию художественного пространства, определяющую значимость пространства не только для индивидуального восприятия, но и для культуры в целом и для всех видов искусства, существующих в рамках конкретной культуры. Пространство, или способ протяженности, является, по его мнению, тем «прасимволом» той или иной культуры, из которого можно вывести весь язык ее форм, отличающий ее от всякой иной.

Художественное пространство проявляется (прорывается), по Шпенглеру, из недр культуры, обусловливается ею как органическое целое, а не является придуманной кем-то конструкцией, введенной в определенное время в оборот. Такое, подчиненное символике культуры пространство изначально лишь ощущается, но не находит выражения в понятиях. В его создании существенную роль играют все компоненты художественного произведения. Широко истолковывая понятие художественного пространства, Шпенглер распространяет его не только на изобразительные искусства, но и на все виды искусства и говорит о пространстве музыки, литературы и т. д. Отсутствие вечных законов искусства означает, по его мнению, что нет никаких, сохраняющихся во все времена и для всех культур принципов создания художественного пространства.

Особое значение для постижения культур Шпенглер придавал раскрытию «прасимволов» пространства в мифах и культах. Анализируя художественное пространство в литературе ненцев, 
мы делаем попытку раскодировать символы или, по Шпенглеру, «прасимволы» мифологических представлений ненцев, отразившиеся в текстах.

В своих поздних работах Ю. М. Лотман рассматривал текст как особую семиотическую структуру. В отличие от ранних работ, где он в основном обращал внимание на структурные элементы текста, в книге «Внутри мыслящих миров» ученый определил текст как открытое пространство смыслопорождения. Текст, так же как язык, кроме функции передачи информации, обладает еще креативной функцией и памятью. Тексту свойственны те же функции, что определяют интеллектуальную способность. Это коммуникативная функция, или функция передачи информации; креативная функция, или функция создания новой информации, обладающей определенной степенью непредсказуемости и памятью.

Как утверждал Ю. Лотман, текст не только генератор новых смыслов, но и конденсатор культурной памяти. Текст обладает способностью сохранять память о своих предшествующих контекстах. Без этого знание о культурах предшествующих эпох было бы невозможно. Если бы текст оставался в сознании воспринимающего только самим собой, то прошлое представлялось бы нам мозаикой несвязных отрывков. Сумма контекстов, в которых данный текст приобретает осмысленность, и которые определяющим образом как бы инкорпорированы в нем, может быть названа памятью текста. К числу сохраненных в памяти ненецких текстов можно отнести, в первую очередь, богатое фольклорное наследие. Именно из него черпают литераторы мифологические символы, дающие простор для многообразных интерпретаций, поскольку они уже имеют художественную природу.

Художественное пространство, создаваемое ненецкими авторами, решает кроме создания поэтических образов, передачи смысловой множественности текста, завуалированную и важную задачу - преодолеть культурную отдаленность, дистанцию, отделяющую многонациональных читателей от малопонятного, «чуждого» им текста, поставить его на один с ним уровень и, таким образом, включить смысл этого текста в нынешнее понимание, каким обладает читатель.

Художественное пространство текста в значительной степени этнично, национально. В книге «Этносфера: история людей и история природы» Л. Н. Гумилев ${ }^{7}$ убедительно доказывает, что реальное регионально-географическое пространство откладыва- 
ет неизбежный отпечаток на ментальность этноса, формируя психологический облик его представителей, этнокультурные и онтологические характеристики.

Как месторазвитие тундра и тайга отразились на ментальности ненцев, на их мироощущении, т. е. на их подсознательной реакции на окружающую реальность, о чем можно судить, в частности, по архетипам и их трансформации как в фольклоре, так и в литературе - вопросы эти остаются, в основном, без ответов.

Своеобычностью художественного пространства в литературе ненцев является его мифопоэтика, в которой отражены образы, модели, созданные сознанием на основе бытия - тундры и лесотундры, определивших образ жизни кочевого народа.

\section{О мифопоэтике пространства}

В большинстве художественных текстов ненецких поэтов и прозаиков проявляется подлинно мифопоэтическое пространство, значительно отличающееся от «технизированных», порой заштампованных образов пространства. Это можно сказать, присвоенное себе, обжитое, одухотворенное пространство. Кроме того, оно «населено» фольклорными мотивами и сюжетами, мифологическими и фольклорными персонажами.

Ненецкая литература позволяет подойти к пониманию мифологического мышления, магической культуры, которая в той или иной степени соприкасается в пространстве и времени со многими культурами мира.

Мифология представляет собой своеобразную, исторически первую форму мировоззрения. Она воспринимается как грандиозная, облеченная в фантастическую форму система взглядов и представлений, универсально объясняющих мир и регламентирующих поведение людей в этом мире. Хотя некоторые исследователи мифологического мышления (А. Ф. Лосев, М. И. СтеблинКаменский, Ф. Х. Кессиди) и отрицают наличие у мифа объяснительной, и, следовательно, мировоззренческой функции. «Для мифического сознания как такового миф вовсе не есть ни сказочное бытие, ни даже просто трансцендентное. Это самое реальное и живое, самое непосредственное и даже чувственное бытие», - писал А. Ф. Лосев ${ }^{8}$. Он считал, что для мифического сознания «все явленно и чувственно ощутимо» и соблюдается полное равновесие между «внутренним» и «внешним», идеей и образом, «идеальным» и «реальным» представлениями. 
Шпенглер своеобразно и высоко оценивал мифологические представления: «Сегодня мы безнадежно не в силах понять, что миф - не эстетически удобная игра воображения, но кусок телеснейшей реальности, пронизывающий всю бодрственность человека и глубочайше потрясающий его существование. Эти существа всегда вокруг. Их замечали, не видя. В них верили такой верой, которая отбрасывает мысль о доказательстве» ${ }^{9}$.

«Мифологическое мышление осознает окружающий его мир прежде всего пространственно, это понятное и понятое пространство», - утверждает Д. Н. Замятин ${ }^{10}$, исследуя принципы формирования образов географического пространства на основе гештальт-психологии Л. М. Веккера.

Герои ненецких фольклорных и литературных произведений постоянно «путешествуют» в соответствии со своими мифологическими пространственными представлениями по трем мирам: среднему, верхнему и нижнему.

В исследовании Е. Т. Пушкаревой «Миф-сказка в фольклоре ненцев: историческая типология и этническая специфика» на основе анализа мифа-сказки сделано своеобразное подтверждение этнолога Л. В. Хомич и фольклориста 3. Н. Куприяновой о трехчастном делении пространства: «...система пространственных представлений в ненецкой мифологии состоит из двух систем “горизонтальной” и “вертикальной”. "Горизонтальная” часть состоит из земли людей, т. е. освоенной территории и земли различных чудовищ, земли неосвоенной. "Вертикальная" состоит из среднего мира - земли, небожителей и подземного мира - обиталища различного рода хтонических существ» ${ }^{11}$.

Мифологическое восприятие пространства ненецкими авторами и героями проявляется в соответствии с теми принципами, которые в литературах и этнологии народов Севера при объяснении взаимоотношений человека и природы обозначены анимизмом. В процессе анализа удалось выявить проявление и других древнейших проторелигиозных представлений ненцев. Так, отзвуки антропоморфизма ${ }^{12}$ в литературе ненцев также отразились во всей полноте звучания. Герои ненецких произведений постоянно стремятся наделить предметы реальности человеческими свойствами, в первую очередь, для того, чтобы понять и освоить их. Не менее ярко проявляется в восприятии окружающего мира у ненцев и «закон сопричастности». Сопричастностью французский ученый Леви-Брюль назвал особое, мистическое единство вещей. Находящиеся в единстве вещи, явления 
«сопричастны» одной духовной силе, которая управляет ими. Bсе происходящее с одной вещью воздействует и на сопричастные с нею другие вещи. Герой, принадлежащий какому-либо роду, чувствует себя сопричастным с ним, с тотемом рода, он как бы живет с ними одной жизнью. Сопричастность друг другу определялась на основании самых различных и порой часто совершенно случайных обстоятельств. Логическое средство установления сопричастности - аналогия, сходство по каким-либо признакам. Обнаружив сопричастность, человек не сомневался, что может воздействовать на людей и животных, манипулируя их изображениями на рисунках или скульптурными изображениями.

Ненецкие поэты и писатели представили в своих произведениях восприятие пространства как одушевленной сущности с определенной структурой. В пространстве раскрываются формы природного бытия и человеческого обитания, отражено и «очеловечение» вселенского пространства. Так, в повести «Илир» Анна Неркаги сконструировала выразительную модель освоения ненцами окружающего пространства, «очеловечения» его на примере развивающихся отношений между оленеводом Мерчей и скалой. Возвращаясь с охоты, оленевод присел отдохнуть у отвесной скалы, неожиданно за спиной послышался рев и появился огромный медведь, приготовившийся к прыжку. Мерча закрыл глаза и простился с жизнью. Сильные эмоции страха и оцепенение охватили мужчину, когда он, открыв глаза, увидел, что перед ним лежит зверь, убитый камнем с отвесной скалы. Благодарный скале за помощь, он простоял на коленях всю светлую летнюю ночь. С появлением солнца Мерча поднялся, посмотрел на скалу и увидел, «что спасшая его скала похожа на сидящего с опущенной головой человека. В этой каменной фигуре угадывались скрытая сила и мощь». В благодарность мужчина весной осуществил жертвоприношение - «десять десятков вольных красавцев оленей», а потом ежегодно приносил в дар спасшей его скале менаруя, лучшего оленя. «Он будто сроднился со спасшей его скалой: советовался с ней, жаловался на невзгоды, делился радостью. Никто в стойбище не понимал такого странного братства человека и камня. Может, это и было святое единение ненца с Землей, о котором говорится в древних преданиях?»

Представленное в повести единение, братство со скалой — яркий пример мифологического восприятия, фетишизма окружающей природы ненцами, своеобразное обоснование того, как и почему человек, бессильный перед неотвратимой бедой, признал за 
скалой силу и мощь, одушевил ее. Неркаги художественно описала процесс субъективного упорядочения трансцендентальной формы познания мира ненцами - окружающего пространства.

В повести мифы компенсируют бессилие и оленевода Мерчи, и мальчика Илира перед жизненными трудностями, опасностями и несчастьями: вера в чудо, в помощь непонятных, но могущественных сил, исходящих от скал, пробуждает у героев жизненные надежды, поднимает дух, способствует развитию самовнушения, помогает справляться с тягостными невзгодами. Именно вера в миф в определенной степени избавляет доведенного до крайней степени отчаяния Илира от психического напряжения, миф о «живых» скалах-великанах открывает простор для его иррациональной фантазии.

В повести Анны Неркаги «Илир» представлены горы как сакральные символы человеческих взаимоотношений. Это некогда окаменевшие от злобы маленьких людей добрые и сильные великаны. Великаны жили в окружении тепла и света незаходящего солнца, красоты жилищ, поскольку их чумы были покрыты цветами и травами, усыпаны ягодами. Вечерами они собирались вокруг никогда не засыпающего очага, благодарили солнце за тепло, землю - за прочность и богатство, приносили им щедрые дары. Доброта великанов была безгранична, они не умели злиться и плакать, они всегда улыбались красивыми и щедрыми улыбками. «Слабого они поднимали, а взгрустнувшего веселили». В изложенной А. Неркаги ненецкой легенде просматривается ностальгия человека по потерянному мифическому раю. Картина идеального человечества, пребывающего в блаженстве и наслаждающегося жизнью, нарисованная в легенде, совпадает с намеками на некую, весьма отдаленную эпоху, когда люди не знали ни страха, ни забот, ни смерти, ни страданий, которые, кстати, содержатся в мифах разных народов. Вечная идиллия в ненецкой легенде была прервана нападением на одного из великанов «маленьких юрких человечков со злыми лицами», которые убили его. Было совершено невиданное злодеяние, непростительный грех. Великаны, прижавшись друг к другу плечами и усадив детей на колени, по совету старейшего, стали горевать и думать, как оживить сородича и победить маленьких людей. От тяжести мыслей головы их склонились на грудь, волосы поседели, тела затвердели. Жилища до самых верхушек заросли дикой и сорной травой, а Великий очаг постепенно угас. Отсутствие любви и заботы, горе и тяжелые думы погубили добрых и весе- 
лых великанов, они окаменели и превратились в скалы. Однако их милосердные сердца, спрятанные в расщелинах, прикрытые пушистым ягелем, остались живыми, и они стали помогать нуждающимся в поддержке добрым людям. Великаны при жизни осуществляли связь с небом, поскольку доставали до него рукой, и по утрам обтирались прохладными чистыми облаками. Эта способность мифических великанов в сознании ненцев была перенесена на высокие горы, скалы и даже просто камни. Об этом свидетельствует отношение к ним героев, и, соответственно, вера в сакральность гор и камней А. Неркаги, автора повести. Поверил в силу гор Илир - сирота, уподобленный жестокосердным хозяином собаке. Благодаря этой вере он превратился в гордого, сильного, независимого человека. Дорога к горам для Илира была трудна и опасна, на грани жизни и смерти, испытания, которым он подвергался, были сродни ритуалам инициации. Бесчеловечные унижения, которым подвергался мальчик, сделали его жизнь невыносимой, и только вера в сакральность гор спасла его. Отождествление скал, среди которых герой пас оленей, со скалами небесными, о которых он слышал легенду, превратила безнадежную жизнь мальчика в осмысленную. Сакральное стало более действенным и реальным, чем мирское.

В мифическом сознании ненецких героев душа является порождением внешнего мира и живет в нем, поэтому для них важно примириться с этим миром, найти точки соприкосновения, овладеть способностями, которые приносили бы радость жизни, например, научиться летать, как птицы, быть стойкими, как горы. Один из способов приближения - тайное, скрытое от окружающих общение с пространством. В повести «Белый ягель» о своих уединенных сокровенных разговорах с горами старый Пэтко не только признается, но и передает как завещание молодому соседу по стойбищу Алешке, не дождавшись приезда дочери. Он обращается с просьбой поехать к сердцу Великих гор — к Пэ-Сюмб, где «лицом к восходу стоят на неприступных скалах хозяева гор, покрытые божественными одеждами - Белым ягелем, чистым, как седины», где еще в начале своей жизни поставил он дорогого ему идола «в тени теней, глубоко за спинами Великих». Воспринимая горы как сакральное место, а идола как покровителя рода, герой ездил к ним в важные для его жизни моменты. Передавая эстафету, старик просит молодого человека поехать в священное для него место в первый раз сразу же после его кончины: «Разведи огонь, угости и говори с ним, как сейчас со мной». 
В повести «Илир», а также в «Анико из рода Ного», «Белый ягель», «Молчащий» Анна Неркаги стремится предъявить с помощью включенных в текст мифов и легенд отрешенность героев от эмпирического протекания событий, описать сознание, в котором аллегория предстает как выразительное бытие, стремление установить смысловые отношения с окружающим.

\section{Космология художественного пространства}

Космизм в ненецкой литературе - отражение глубинного мифопоэтического сознания, поиск авторами и героями себя в бескрайнем мире. Космические мироощущения наполнены сопричастностью к энергетике космических тел. У поэтов и писателей они будят воображение, рождают вдохновенные образы. Космология организует мир героев.

Космическое пространство, небесные светила являлись у ненцев предметом культа, обращение к ним влияло на быт, жизненный уклад, на судьбу и успех/неудачу.

\footnotetext{
Когда над сопкой небеса ясны

Род кочевой глядел в лицо созвездий, Ища в них знаки тайные предвестий, Чтоб угадать нрав будущей весны Чтоб разглядеть незримый след судьбы, Чтоб угадать грядущие невзгоды...
}

(П. Явтысый. «Когда над сопкой...»)

Стихотворение написано в девяностые годы, время смены социальной парадигмы. В так называемое «осевое» время, период перемен, в разных обществах обычно возникают критические уровни интерпретации сложившейся культуры. Обостренное самосознание личности порождает обращение к накопленному опыту восприятия мира. «Письмена небесных звезд», которые отторгались под напором пропаганды атеизма, постепенно стали проявляться в сознании ненцев в конце XX века, хотя, по мнению поэта Прокопия Явтысыя, «к их прочтенью души не созрели».

Эволюция сознания ненцев - зарождения, постижения себя и своего внутреннего мира в древности - осуществлялась в тесной связи с представлениями о творении Вселенной. В ненецкой мифологии мир до начала всего представлен как царство воды. Нум (высшее божество, с которым олицетворяется небо) отправил гагару в глубь. Нырнув, она принесла в клюве ком глины. 
Эта частица тверди стала расти и превратилась в землю, на которой постепенно появились горы и реки, животные и люди. «От иных самоедов я слышал, что и земля, и море, и вся природа тоже Нум», - писал в конце XIX века лингвист, фольклорист А. Кастрен в записках о путешествии к самоедам в 1842 году $^{13}$. По мнению других исследователей, в частности этнографа Л. В. Хомич, Нум, «существо бестелесное, не имеющее никакого образа» был не только творцом Земли, но и всего сущего. «Однако, сотворив всё это, Нум устранился от дальнейшего вмешательства в земные дела, предоставив это духам - тадебцё» ${ }^{14}$.

Это утверждение этнологов о невмешательстве Нума в земные дела опровергается, по крайней мере, по-особому трактуется в ненецкой литературе. Герои произведений ненецких поэтов и писателей нередко обращаются к Нуму, творцу и защитнику, а порой и обидчику. Так, героиня рассказа Л. Ненянг «Таймырская быль» объясняет свое нынешнее зависимое положение безропотной батрачки вмешательством в ее жизнь Нума: «В молодости и Неле, и Хаке были жизнерадостными, трудолюбивыми. Нелегко они добывали свое счастье, но вместе лучше, чем теперь, когда Хаке нет рядом. Его давно забрал Нум - дух Неба».

Для ненецких авторов и героев, в том числе лирических, Bселенная одухотворена, тесно связана с их жизнью, смоделирована согласно версиям «культурной памяти».

Я здесь родился.

Здесь впервые

Взглянуло небо на меня.

(В. Ледков. «Скала»)

Глядя в ночное небо, лирический герой другого стихотворения Ледкова «Ночь» представил удивительную сказочную картину, как он поделился тайными мыслями с небом, а выкатившаяся луна рассказала их глубоким снегам, бросая на землю «звенящие кольца».

Присутствуют в фольклоре и в литературе ненцев разные миры, не только верхний (небесный), срединный (земной) и нижний (подземный), но еще и «разные небеса». О существовании в мифологии ненцев «разных небес» писала и этнограф Л. В. Хомич: «Над нашей землей якобы находится семь небес. Они как одно целое передвигаются над землей с прикрепленными к ним луной и солнцем. Солнце и луна временами не бывают видны с земли, потому что небосвод сдвигается в ту или иную сторону. 
Небо имеет выпуклую форму и краями упирается в землю, как опрокинутая чаша.

На небесах тоже живут люди (нув, хасава - небесные люди), обладающие оленями. Когда на нижнем небе тает снег, он стекает в виде дождя на нашу землю. Звезды - озера на той земле, которая служит нам небосводом. Они передвигаются вместе с этой “верхней” землей.

Земля - плоская, немного взгорбленная посередине, где имеются горы, с которых в разные стороны текут реки, в том числе и Обь. Земля окружена морем.

Под нашей землей есть еще семь земель. На первой из них живут сиртя (в восточных говорах сихиртя), для них небом служит наша земля. Солнце и луна - одни для всех миров; они светят для сиртя сквозь воду и нашу землю» ${ }^{15}$.

Вселенная, ее пространство предстают и в фольклоре, и в литературе ненцев как структурированная реальность, с которой человек связан таинственными, изменчивыми порой, фатальными узами. Отражается в этой реальности жизнь как некое состояние между солнцем (теплом) и темнотой (холодом).

Солнце - самое воспеваемое ненцами светило, поскольку с появлением его после полярной ночи связывают и начало жизни, и начало года.

А год, как водится, с весны

Берет свое начало.

Спина крутой морской волны

Его сперва качает,

Чтоб вырос он большим, большим

Для всех своих свершений,

Чтоб плыли в тундре аргиши

И множились олени.

\section{(А. Пичков. «В кругу родныхх))}

Весну ждут с нетерпением, она несет с собой «радостный рассвет», новые пути, «врачует» тяжелые воспоминания. По мнению лирического героя стихотворения Ледкова «Вода зиме сказала», весной изменяются и отношения с верхним миром, который становится более благосклонным к человеку:

Мне небо улыбнется из воды

И солнышко присядет на торосах.

* Сиртя, сихиртя - люди, которые, согласно легендам, жили в тундре до прихода ненцев и ушли потом жить под землю. 
Весенний шум речного ледохода, голубые краски весны пробуждают жизнь в тундре, активизируют людей: «и чей-то веселый свадебный поезд / тронется прямо навстречу заре» (В. Ледков. «Ивовое море»).

«Рожденье солнца - первый крик весны», тундра просыпается, березка «пьет этот солнечный свет, / что спрятан в земле, Как источник рожденья». Поэт отогревается душой, поскольку весной «в душе ни метелей, ни холода нет. - Есть мир и земля / в настроеньи весеннем».

Я понял — с весны

Начинается год.

Весною я сам обновляюсь, Не скрою.

(А. Пичков. «Ручей, как парнишка...»)

Таинственный феномен природы - ее вечное замирание и возрождение - тревожит мысль ненецких поэтов, притягивает особое внимание к началу творения - весне, споспешествует творческому вдохновению и любви.

Когда снега в просторах тундры тают,

Рождая ощущенье новизны, -

Слова любви на крыльях птиц взлетают

В звенящую безбрежность синевы!

Слова любви - стихами прорастают

Сквозь теплый снег,

Сквозь ягель и сквозь сны.

И образ твой бессчетно повторяют

Цветы, как символ солнечной весны.

(Явтысый. «Когда снега...»)

Путь природы к весне - это ожидание света, солнечного тепла. Категория художественного пространства ненецкими поэтами и писателями часто строится на использовании семантики света. Пронизанные солнцем пейзажи значимы эстетически и этически.

В стихотворении А. Пичкова «Через снег и пургу...» лирический герой связывает пробуждение природы с деятельностью человека, с его активностью:

Раньше всех нам свиданье весна

За далекой горой назначает,

Нам, идущим сквозь грозы и бури вперед.

Я иду там, где желтое солнце пылает,

Там, где зори уже из огней

Собирают большой хоровод. 
Солнце в ненецком фольклоре и литературе - символ добра и надежд, источник жизненных сил для людей и всего окружающего мира. Появление его весной приносит пробуждение энергии, освобождение от депрессивного зимнего замирания эмоций.

Освободясь от суетного гнета,

Решительно прогнав тоску и грусть,

Я за крыло дня вешнего держусь,

На тундру глядя с птичьего полета.

(П. Явтысый. «Освободясь от суетного гнета...»)

Л. Ненянг в сюжет рассказа «Таймырская быль» включает одну из легенд о солнце, чтобы вселить надежду на чудо девочке Сатте и раскрыть тайные мысли матери-рассказчицы, попавшей в тяжелое зависимое положение батрачки после смерти мужа. В легенде храбрый богатырь Сатако семь дней и семь ночей сражается до последних сил с темными и злыми духами и великаном Сюдбю Вэсэем, чтобы освободить спрятанное под землей солнце. Обессилев, богатырь падает и засыпает надолго, а проснувшись, видит долгожданное и выстраданное в сражениях солнце. «Радужные лучи солнца ласкали его лицо, щекотали усы. В теле он чувствовал силу и здоровье, голова была ясной. И солнце, огромное, яркое, обливает землю горячими лучами. Сатако понял, что люди пришли ему на помощь и отвоевали солнце у Сюдбю Вэсэяя. Теперь на землю пришло счастье...».

Солнечный круговорот переплетен в мифопоэтическом сознании ненцев с постоянным циклическим зарождением и замиранием природы и жизни. Отразился он на создании поэтической модели мира и у прозаиков, и у поэтов.

Мыслью поэта о сотворении мира наполнено стихотворение П. Явтысыя «Первый день весны...», в котором он отсчитывает дни прихода весны как дни божественного творения мира. Каждый из шести дней дарит новизну видения солнца, тундры, птиц, зверей, дороги и в конце дарит встречу с любимой. «Так для нас двоих / Мир был создан снова».

Подсознательные идеи - рождения жизни, движения в пространстве, твердой опоры существования и другие - стали основой архетипов как понятий разума и души. Душа, по К. Юнгу, - отражение Вселенной. И архетипы, составляющие ее содержимое в своей первоначальной форме - простые природные образы. Это образы моря, неба, земли, огня, которые были символами сразу же, как человек начал выделять их из обще- 
го пейзажа и оформлять свой взгляд на мир при помощи этих внешних ориентиров. Позднее осознание природных явлений и их роли в жизни человека привело к созданию мифов ${ }^{16}$.

Мифологические представления о мире удивительно подобны в разных культурах мира. Используя сравнение разных мифов и обрядов для интерпретации смысла этих представлений, Дж. Фрэзер писал: «Исследования в области древнейшей истории человечества обнаружили, что при множестве поверхностных различий первые философские системы, выработанные человеческим разумом, сходны в своих существенных чертах» ${ }^{17}$. Синхронность психического восприятия событий на разных концах земли, в культурах никогда не пересекавшихся между собой народов, наводит психологов, философов, астрологов на мысль о влиянии космических ритмов на коллективные подсознательные процессы.

Коллективное подсознательное, по Юнгу, - это существование некоего коллективного базового пласта души, из которого возникают продукты фантазии, мифологические типы. Переплетаясь с индивидуальными фантазиями личного характера, которые восходят к лично-пережитому, полузабытому или вытесненному, коллективное бессознательное «автохтонно» возрождает неосознаваемый ранее материал.

Мифология и литература многих народов отражают негативное восприятие ночи как символа тьмы, таящего в себе угрозу. Уход солнца, наступление полярной ночи приносит ненцам тревогу за выживание и страх, поскольку ночь и темнота сковывающе действуют на волю и жизнедеятельность людей, пробуждают активность духов зла. И в это время ненцы обращаются к Луне как источнику света.

В стихотворении Л. Лапцуя «Великое кочевье» предстает зимний темный период, когда наступает Месяц Большой Темноты, и «Дни трепещут в лапах тьмы когтистой, / Как куропатка, истекая кровью, / На плечи тьма тяжеловесно давит», тогда глаза кочевника «Глядят прищурясь в сторону востока. / И ждут восхода бронзовой луны». Лунный свет зимой животворящ, освещает путь оленеводу во тьме полярной ночи.

Лети, лети, аргиш кустоголовый, Под лунным светом тундра серебрится. И лунный луч - хорей для всех созвездий, Как будто для упряжек в небесах.

(Л. Лапиуй. «Великое кочевье») 
Антропоморфизм помог поэту создать образ лунного луча, ставшего хореем, представить небесные созвездия в виде упряжек.

Во время пурги кочевники с нетерпением ждут проблеска луны, которая осветит путь, поддержит и поможет, ведь она непрестанно наблюдает за их жизнью:

А в небе луна, что не раз выручала,

Любви помогала, в тумане вела,

Глядит с высоты на просторы Ямала -

На тропы зверей и людские дела.

\section{(Л. Лапиуй. «При луне»)}

Темные пятна на луне воспринимались ненцами как силуэты мужчины и собаки, что подтверждают и сказки. Леонид Лапцуй использовал этот образ, чтобы выразительнее возвысить главного героя рассказа «Палочки с зарубками», подчеркнуть профессионализм оленевода: «Лишь мужчина, живущий на луне вместе со своей собакой, всю жизнь не может собрать своих оленейзвезд. Атена всегда соберет свое стадо».

В темную полярную ночь звезды для ненцев и ориентиры в пространстве, и источники дружеского участия в судьбе:

\section{Не звезды это \\ Блестят вдали, \\ Осколки света, \\ Добра, любви.}

(В. Ледков. «Гони оленей...»)

Полярная звезда Нгэрм нумгы в полярную ночь наряду с луной - успокаивающий, живительный источник света. В стихотворении «В небе светится...» А. Пичкова звучит подтверждение: «Вновь меня ласкает взглядом / Моя Полярная звезда...», «Как и прежде светла Нгэрм нумгы. / Ночь темна, но светла дорога». Однако отношение к Полярной звезде у ненцев дуалистическое. Ей приписывали и негативное отношение к людям.

Северное сияние - это большой костер на небе, который разводят добрые духи. Сполохи северного сияния назвал Л. Лапцуй «радугой жизни». Под этим названием вышла одна из его книг.

Разнообразен характер взаимоотношений со сторонами света у ненецких авторов и их героев. Разделение направлений на четыре стороны света связано с идеей видимого кругового движения Солнца. Восток (левая сторона) - начало движения солнечного диска, юг (верх) - движение вперед, запад (правая сторона) - 
продолжение движения, север (низ) - окончание движения. Стороны света распределены по своему влиянию на человека как позитивные и негативные. Восток связывается с положительным началом, со всем чистым и животворным. Утренняя заря воспевается поэтами как предвестница солнца и добра. Так, лирический герой стихотворения П. Явтысыя «В стремительном беге» встречает восторженной песней утреннюю зарю, которая венцом покрывает сопку и делает ее «царицей». Запад был опасен для ненца, это был мир злых существ, уносящих солнце. Вечерняя заря, связанная с заходом солнца, в отличие от утренней, овеяна негативом. «В костре заката чтобы не сгореть, / я тороплюсь от крыльев отцепиться», - рассказывает лирический герой стихотворения П. Явтысыя «Освободясь от суетного гнева...», который мысленно поднялся в весеннее небо на высоту птичьего полета. Север - сторона холода, зла и олицетворяется часто с Нижним миром, поэтому и являются образы: «Надвигается тьма, / Стужа злая» (В. Ледков), «И белого Севера черная дочь / Владычит наследно полярная ночь» (Л. Лапцуй). Стороной доброго начала и тепла является юг. Он олицетворяется с Верхним миром, с летом. Эстетика летнего пейзажа наполнена радостью и покоем.

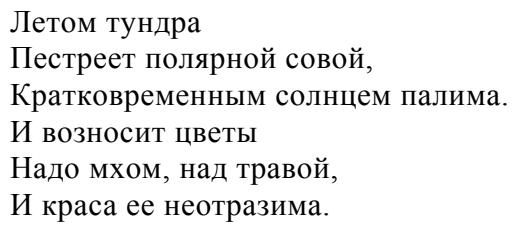

(Л. Лапиуй. «Летом в тундре»)

Сознательно или бессознательно, но в литературе ненцев реактуализируется мифообраз Древа Жизни. Реальный пейзаж тундры, представленный как в ненецком эпосе, так и в литературе, почти не содержит описаний деревьев, но присутствует «ветвистое дерево» или коряга, которые оказываются спасительным транспортом для героев, оказавшихся на оторванной от берега льдине. Так, герой эпической песни «Безоленный человек» в поисках удачи отправился «в неизвестном направлении» и оказался на льдине. Покорившись судьбе, он пребывал в постоянном состоянии сна, и «сквозь сон» мужчина услышал слова о лодке, пришедшей для его спасения, но, проснувшись, ни лодки, ни людей он не увидел и снова уснул. После второго предупреждения он стал внимательно всматриваться и, хотя лодки не нашел, увидел ветвистое дерево и понял, что оно и есть его лодка. С трудом прыгнув на 
него, мужчина лег среди корней и приплыл на нем к берегу. Спасительными оказались больше корни дерева, чем его ветви.

Главный герой поэмы-сказки Лапцуя «Тёр» тоже оказался на быстро тающей льдине и был на краю смерти. Во сне он услышал голос волшебного бубна: «Вон лодка твоя по теченью плывет! /Лови и ложись посредине». Проснувшись, Тёр не увидел обещанной лодки, но вскоре обратил внимание на «замшелую, в крепких сучках по бокам» корягу. «И к Тёру как новые силы пришли! / Согнувши колена и спину, / К той черной коряге - частице земли / Он на десять прыгнул аршинов. / На мху, между сильных корявых сучков / Залег поудобней в середке. / Весенним дыханьем травы и цветов / Запахла волшебная лодка. Пригрелся в ней Тёр, словно птенчик в гнезде, / Нежданному счастью не веря...»

Спасительное дерево в поэме-сказке - символ Древа Жизни. Семантически нагруженной частью дерева является корень. В сказках ненцев он даже живет своей особой отдельной жизнью: коряга спасает героев, оказавшихся на льдине. Мифообраз корня - обретение героем почвы, укоренение человека в своем миpe, спасение. В автохтонном ${ }^{*}$ мире человек находит поддержку, цель, прорастает корнями.

\section{Концепт круга в мироощущении героев}

Для осознания себя человеку необходимо в качестве психологической опоры представлять себе некий пространственный предел, в который он себя помещает. Он как бы замыкает пространство вокруг себя и идеализирует его. С участием концепта «круг» формировались опорные мифолого-поэтические, космологические представления у ненцев, как и у всего человечества. В древнейшей картине мироздания круг - это образ Солнца; суточное и годовое движение Земли осознаются как движения по кругу; происходят круговороты дня и ночи, времен года, лунных фаз, круговороты жизни природы. Границы пространства постепенно выходят за пределы чувственного восприятия, они расширяются в процессе деятельности. Они также расширяются за счет памяти и воображения. Представляя пространство, герои рисуют себе мысленным взором не только стойбище и чум, но и часть земли в пределах видимого горизонта, и вселенную.

Автохтоны - первоначальное, исконное население страны, аборигены. Автохтонный - возникший на месте современного местонахождения. 
У ненцев значения, связанные с отображением круговых и вращательных движений, образуют пеструю область многочисленных сакральных представлений, которые давно и с полной естественностью укоренились во всех тематических областях обыденного сознания. В качестве оберега ненцы использовали, например, окружение своего пространства кругами, которые делали или с помощью ремней или просто обходили, создавая непреодолимое препятствие для злых духов. Круг использовали не только в качестве оберега, но и заговора. В поэме «Тёр» главный герой использует круг в качестве заговора врагов. Вспомнив совет Трехкосой, он «по-хозяйски приказал / Головному другу, / Чтобы тропку проторил / Без узды по кругу». Так была опоясана «рать врага, как петлей аркана». Тёр создал с помощью заговора препятствие для врагов, чтобы они не смогли покинуть очерченный круг.

Магия в своем возникновении стремилась не только к познанию мира, она как бы выражала протест человека против ига природы и стремилась победить ее самовластие. Издревле использовались не только бурные телодвижения и непонятные слова, но и напряженные усилия воли, ритуальные действия, запреты. Круг - своеобразный знак. Чаще всего круг - это остановка, замыкание. Он обозначает, что внутри его сакральное пространство, в нем возможно совершение обрядов, но противопоказана любая борьба, запрещено сражение. Сражаться, что есть мочи, бежать вперед, пока остается пространство открытым, может и человек, и зверь. Но как только смыкается круг, сопротивление словно по мановению волшебной палочки прекращается. Так ведут себя олени, песцы и даже волки. В героических сказаниях ненцев так вели себя и войска, окруженные врагами. Они сразу превращались в обреченных на гибель. Когда аргиш (своеобразный поезд из оленьих упряжек) движется, он вытягивается в струну, когда останавливается, то изгибается полукругом. Отпечаток круга оставляет на земле чум. Все обряды сопровождаются круговыми движениями.

Однако круг может стать и символом любви, и безутешного горя при потере любимой, и знаком бесконечного движения. В основу стихотворения «Олень и луна» Л. Ненянг положена легенда об олене, потерявшем во время пурги свою подругу, который ищет ее в течение семи дней в «мятущейся мгле», трубит и даже от горя роняет слезу. Когда же в полночь утихла круговерть, «И тропою светил луна поднялась, / сквозь туман заблистала», олень, устремив взгляд на серебряный свет, увидел не 
луну, а подругу. «С тех пор и бежит за луною он вслед / Как заведенный, / по кругу - по кругу».

В стихотворении представлена и специфика движения оленей, которые часто стараются двигаться по кругу. Автор как бы нацеливает на восприятие природы как живого организма, в котором много таинственного и взаимосвязанного. Человек в его вселенском модусе - лишь звено круговорота, поэтому в его эпосе герои нередко, как в литературе, равновелики, будь то человек, животное, насекомое, природный объект большой либо малой величины.

Веревочный загон для оленей у ненцев, как и других народов Севера, сделан в форме круга. Добрым знаком служит, если все или почти все ездовые олени входят в загон. Это означает, что они согласны надеть узду и нести упряжку. Если олень убегает от аркана, никто не сделает попытки поймать его больше трех раз.

Используя концепт «круг», ненецкие поэты создают выразительные образы оленеводов, отличающихся находчивостью и мужеством в борьбе с обидчиками-врагами, умением жить в единстве с природой.

\section{Тундра - самовластный и покоряемый, реальный и сакральный топос}

Основной топос в произведениях ненцев - тундра. Персонажи помещены в ее пространство. Она имеет онтологическую прочность, не нуждаясь в гносеологии, усилиях человека. Тундра присутствует латентно, проявляясь в разнообразных концепциях, но превалирует близость ее человеку. Она способна распознавать врагов и друзей, это некий сакральный топос, в котором заключена информация, понять ее могут только избранные.

В поэме-сказке Л. Лапцуя «Тёр» постоянно присутствует одушевленный, сакральный образ Тундры. Она то одобряет поступки героя, то сердится на недостойное поведение (герой проявил слабость и открыл тайну своих помощников врагам, а те продали их в чужеземную страну), то испытывает его на стойкость и выдержку, насылая тьму, «необычной силы ветер», пургу или дождь. Когда же тьма, вызывающая страх, постепенно «уползает волчьей тенью», герой понимает, что испытание закончилось, и он может исполнять задуманное. Свою устремленность к подвигам во имя всего живого в тундре Тёр объясняет тем, что выполнял «волю тундры». 
Архетип тундры-матери, который возрождают ненецкие поэты, может быть связан с истоками человеческой истории, когда представление о возникновении мира не отделялось от природного процесса рождения. Образ матери, рождающей людей и все силы природы, - самый древний мифологический образ. Великая Праматерь стала культом, которому поклонялись, поскольку процесс рождения жизни был перенесен от рождения человека и природы на Вселенную. Мать-земля, мать-тундра, ассоциировалась в сознании ненцев с прочностью и надежностью, с той хтонической мощью, которую она передает своим потомкам.

Образ матери-тундры являлся для Л. Лапцуя действенной, активизирующей силой, способствовавшей созданию глубоких по мысли, национально-специфических произведений. Вымышленная Женщина-Тундра, «Ямала добрая душа», постоянно волновала и помогала поэту в его творчестве. Стихию поэт воспринимает как обиду тундры на какие-то неправедные поступки. «В большой обиде на меня родная тундра», - предположил Тёр, когда на него «смертным каменным обвалом» обрушилась ледяная пурга. Однако, когда утром тьма ненастная уползла «волчьей тенью» и появилось солнце, герой, «нежным взглядом даль окинув», пришел к пониманию иного отношения тундры к нему: перед дорогой «в канун разлуки испытала тундра сына».

Устремляются в бескрайние просторы тундры за поддержкой и подпиткой, чтобы набраться силы, мудрости, доброты лирические герои стихотворений и поэм не только Л. Лапцуя, но и В. Ледкова, П. Явтысыя, А. Пичкова.

В стихотворении В. Ледкова «Ну, садись на нарты, пассажир мой!» герой предлагает укрепиться во время поездки в тундру и запастись дружбой и песнями жителю города, давно покинувшему бескрайние просторы. Причина такого совета - зов Тундры-Матери, оставшейся без заботливых, согревавших ее рук, сердец, тел. Лирическому герою она постоянно является во снах: «Но во снах - бескрайняя, живая, /Тундра мне является всегда». Архетип Матери-Тундры, являющийся во снах, жизнеспособен, активизирует мысли, побуждает к призыву действовать.

Эмоциональное взаимодействие с Матерью-Тундрой порой соответствует отношениям матери и сына. Так, В. Ледков высоко оценивает роль Матери-Тундры в его мужании и росте, определяя ее заботу метафорой: «Я, словно клюквинка-кровинка, / Взращен тобою на корню» (стихотворение «Нить раскаленная заката...»). В ответ на былую заботу он, как благодарный сын, 
утешает ее в сложное время: «Спи, тундра. / Я тебе, усталой, / Наворожу цветные сны»; обещает расправиться с трудностями: «Не бойся туч! / Я их лавину / Рукой сыновней разгоню».

В. Ледков чувствует свою ответственность за сохранность природы в тундре, кается за своё невнимание к ней: «Перед этой землей на колени я готов как пред матерью встать» (стихотворение «Словно звездное небо...»).

Успокаивающее воздействие общения с тундрой, ее своеобразную дидактическую значимость описывает П. Явтысый в стихотворении «Пепел чумовища»: «Тундра меня научила смывать/ снегом нетронутым мрачные думы». В. Ледков в стихотворении «Куда меня только судьба не бросает!» одухотворяет родную землю, приписывая ей роль матери: «Вновь тундра простила меня и пригрела...», «Без тундры я мал, как снежинка зимой».

Не только лирические герои поэтических произведений, но и герои прозы, по-ненецки сдержанные в проявлении эмоций, в сложные жизненные моменты обращаются к тундре, к окружающей природе. Ламдо Сядей, герой романа Ледкова «Люди Большой Медведицы» о своих сомнениях в правильности своего поступка рассказывает не людям, а обращается к тундре. «Уже намечались первые робкие следы желтоногой осени. Словно токующая куропатка, он вскакивал на кочки и озирался вокруг. Может, он пытался разглядеть на земле свое неведомо куда утраченное счастье? Земля отвечала ему трубным реханьем оленьих самцов, как всегда в эту пору дерущихся из-за важенок... Как чувствовал себя теперь Ламдо Сядэй, озирающий с высоты тундровой кочки подвластный ему кусочек мира? Может, и до него долетело это первое дуновение свежего осеннего ветерка? Нет. И на этом огромном просторе ему было тесно и душно. Душа кричала на крик, сама не ведая о чем. Нужна была хоть какая-то разрядка». Взволнованный своими мыслями оленевод оттого, что не находил выхода, становился все агрессивнее: «Ненависть к окружающим его людям росла и росла». Но активное общение с природой, глубокое проникновение в нее, попытка увидеть мир глазами куропатки изменили настроение героя, и хоть сомнения продолжали бередить душу, они стали приглушенными, и агрессия затихла.

Приглашает В. Ледков читателя в необъятные тундровые просторы, чтобы раскрыть неповторимость и новизну для новичка жизни и природы, при этом словно просит прощения за то, что покинул ее:

Я и сам успешно обживаю Шумные большие города. 
Но во снах - бескрайняя, живая,

Тундра мне является всегда.

(«Ну, садись на нарты, пассажир мой!»)

Вызывая архетип матери-тундры, олицетворяя природу, П. Явтысый сравнивает себя с родником. Это сравнение свидетельствует о синкретичности его сознания, неразделимой связи с природой. «Кипящий в безбрежности тундры» родник целеустремленно сметает на пути все преграды, несет свежесть вод для усталых путников и оленей, поэт же наполняет свежестью чувств человеческие души. В творческой фантазии Явтысый приписывает роднику свойства доброжелательного человека:

$$
\begin{aligned}
& \text { Чтоб аргиш свой } \\
& \text { до цели } \\
& \text { довел проводник - } \\
& \text { со студеным глотком } \\
& \text { отдадут мои воды: } \\
& \text { силу отчего края } \\
& \text { и мудрость народа... }
\end{aligned}
$$

Традиционная для ненецкого глаза и слуха поэтика пространства насыщена знаковой образностью. Это не «описание» природы и не ее «переживание», не фрагментарная «картина» мира, а его онтологическое присутствие. Данность мира, осмысленная как целостное существование и даже как неделимость его существования.

\section{Простор как жсизнеутверждающий, формирующий личность концепт}

Простор, простирание - одна из отличительных черт тундры. Она несет с собой свободу, открытость для человеческого поселения и обитания, и вместе с ними немало проблем, связанных с обживанием, укоренением, покорением стихий, с поиском ключей для раскрытия тайн окружающей природы. Мифологема тайны органически присуща художественному образу тундры. Ощущение скрытых в ней таинств порождает, в первую очередь, беспредельность пространства.

Над тундрой вьюга носится со свистом,

Как будто бы она холмы Ямала

Строгает яро лезвием каленым,

И нет ей ни начала, ни конца.

\section{(Л. Лапиуй. «Великое кочевье»)}


В этом стихотворении Лапцуя, как и во многих других, в стихах Явтысыя, Ледкова, Пичкова поэтический образ тундры наполнен описанием стихий, ситуаций, в которых проявляется мужественный характер ненцев. В стихотворении «Ветра» П. Явтысый пишет об умении своего лирического героя-ненца противостоять жестоким ветрам и темноте полярной ночи, взятом от предков:

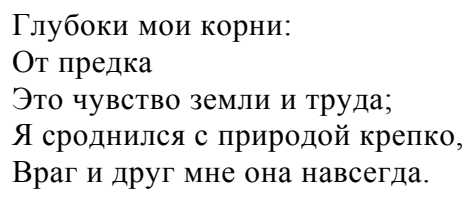

Привлекателен и манящ простор тундры. «Тундра - снежные дали без края», пишет А. Пичков, родившийся в стойбище, но позднее живший в городе Нарьян-Маре. Он постоянно жил с образом «снежной дали без края», сомневался, что ностальгия покинет его: «без тундры, наверно, вдалеке прожить не смогу». Тундра своей бескрайностью и обилием озер, рек и скал на берегах Карского и Баренцева морей притягивает автора и его лирического героя:
А сердце зовет
К берестяным чумам,
Где солнце плывет
По краю ущелья.
Как по кромке ножа.

\section{(А. Пичков. «Все думын..»)}

Зимней порой, когда «нить раскаленная заката», перегорев, обрывается, тундра не просто погружается в полярную ночь, а подобно уставшей матери засыпает: «Заснуло темных сопок стадо, / озера дремою полны». Поэты, как добрые сыновья ее, поют колыбельные песни, в которых обещают заботиться о ее просторах, предрекают радужное будущее:

\footnotetext{
Твои моря - они бездонны.

А сколько прячет твой простор

Мест и бесследных,

И бездомных,

Не прирученных до сих пор!

Чудесно.

Мы и их освоим!

Ну а пока ночная синь

Тебя окутала покоем,

Ты спи и набирайся сил.
}

(В. Ледков. «Кольбельная») 
Бескрайние просторы поэтами соединены с обилием в тундре оленей. Олени - основа жизнедеятельности персонажей. Умело правит оленями и знает дорогу ясовей - проводник, сидящий на первой упряжке, когда движется аргиш - своеобразный поезд из нескольких нарт во время перекочевки.

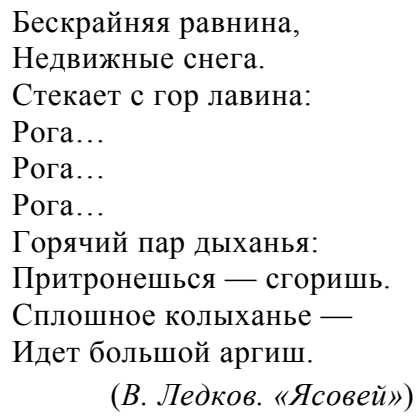

Для кочевника важны даль и ширь, поскольку он находится в постоянном движении. Простор для ненца - это высвобождение от замкнутости обитания в своих стойбищах, открытость, позволяющая надеяться на необычные происшествия в дороге, способные внести новизну в бытие.

Концепт дороги - один из ведущих в литературе ненцев.

Радуют А. Пичкова, побуждают к творчеству поездки по тундре в любое время года.

\begin{abstract}
А дороги - синие прожилки
На руках обветренной земли.

Как меня вы взяли, закружили -

Прямо к сердцу тундры привели.
\end{abstract}

(А. Пичков. «А дороги...»)

Свой жизненный путь герои романа В. Ледкова «Люди Большой Медведицы» сравнивают с дорогой, представляя себя путниками. «Бывает, что события нахлынут нежданно-негаданно, и человек оказывается в положении путника, упустившего из рук вожжу. Упряжка тогда резко свернет в сторону и понесет нарты совсем не туда, куда ехать надо. Рано или поздно человек ухватит ту пляшущую вожжу и снова возьмет управление в свои руки, снова дружно да ладно побежит упряжка».

Перемещаясь в пространстве, герои зачастую обращаются в глубь времен, поскольку мифологема первозданного мира, рож- 
дающегося и развивающегося циклически, постоянно связана с темой прошлого.

\author{
Упряжка белая рванула \\ Во весь опор - \\ И в этот миг \\ В снегу кочевье потонуло, \\ Но, полный молодого гула, \\ Мир детства предо мной возник.
}

(П. Явтысый. «Стихи о матери»)

Простор тундры создает ощущение своеобразной широты в душе, имеется в виду пространственное противопоставление «ширина-узость», отражается на настроении и самочувствии, самоощущении героев. Так, усилилось чувство тоски и одиночества у Игната, героя рассказа В. Ледкова «Чум», поселившегося в «каменном» поселке, оттого, что «грызла душу тоска по простору», и стал ощущать он себя «пустой щепкой, плывущей по воле волн», а в тундре был «частью самой жизни, пусть даже самой маленькой ее частью». В ответ на вопрос девушек, не скучает ли он «по олешкам», старик отвечает: «Как мне не скучать-то? Гнездо-то мое - тундра. Простор...» Просторы тундры он, словно птица, считает своим гнездом. Оленевод долго сопротивлялся переселению его в поселок, не хотел покидать тундру, объясняя: «В ней с первого же шага чувствуешь, что ты не существуешь. А живешь. И мало того: на просторе видишь себя хозяином земли». Когда оленеводу по возрасту пришлось оставить кочевую жизнь, душа его как будто сузилась, «на сердце старика словно олень наступил».

Постоянное кочевье и оседлая жизнь для ненецких героев два противоположных образа жизни, и приобщение к оседлому образу жизни - конфликт не только социальный, но и душевный. Кочевая жизнь приобщает к просторам, к ощущению свободы, к радости движения и дороги, к ощущению постоянного покорения пространства. И хотя многие из героев романа В. Ледкова «Месяц Малой Темноты» (вторая часть носит название «Люди Большой Медведицы») понимают преимущества оседлой жизни, им преодолеть себя сложно. Умудренный жизненным опытом, переборовший себя когда-то и переселившийся в поселок Ядна Як объясняет причины: «...сразу всем привыкнуть к оседлости нелегко, по себе помню. Ведь у каждого из нас свой ветер в голове. Одному, может, и ничего: оглядится и потихоньку да поедет по новой полознице. А другой - душу свою намотает, а к новой жизни так и не приноровится...» Герой по- 
стоянно вспоминает свои первые ощущения от нового жилья: «После чума в деревянном доме и душно было, и голова болела». Он связывает переход от кочевой жизни к оседлой с изменениями душевными: «У каждого тундровика свои думы, привычки, заботы. Придет такой в поселок жить, оглянется, а все родное и близкое в тундре осталось».

Герой романа «Люди Большой Медведицы» оленевод Вавля беспокоится за будущее тундры, не хочет, чтобы молодежь покидала стойбища. Его сын стал интересоваться машинами, не желает быть оленеводом. Мысленно Вавля пытается убедить сына приобщаться к оленеводству, но вслух он уже не идет против течения новой жизни. Согласен с ним и автор, передавая мысли оленевода: «То ли дело тундра! Вавля чувствовал себя в ней будто рыба в воде. Он знал каждый изгиб любой тундровой речушки, мог разговаривать с ветрами, травами, небом. Он хотел, чтобы и его сын стал хозяином тундрового простора, умелым оленеводом и удачливым охотником».

Существует и негативное воздействие безраздельного простора. Он рождает порой чувство одиночества и незащищенности. Так, героиня романа В. Ледкова «Месяц Малой Темноты» убеждает себя расстаться с просторами тундры и своим большим оленьим стадом выразительными словами: «Один человек - что снежинка на ветру, ее и заметить некому. Да и силы никакой в ней нет. Без людей даже богач из богачей ничего не значит. А изотрет снежинку ветер - никто не скажет: была она или нет». Опасность для человека таит простор и в появлении миражей. Во время длительной поездки по тундре на оленьей упряжке восприятие реального пространства у героев порой сменяется миражами. В повести Ледкова «Синева в аркане» миражи видит не только главный герой, но и его спутница, т. е. миражи способны загипнотизировать сразу несколько человек. Сначала герой «в темноте от ощущения пустоты и безмолвия видел уродливые лица, дворцы в огнях и разную чушь». Потом услышала звон в ушах и девушка: «Скачут огненные черти. Скалят зубы какие-то рожи... гримасничают». Избавиться от миража помогает героям огонь. От костра приходит ощущение реальности, темной земли и неба.

\section{Топографическая память и освоение пространства}

В ненецкой литературе нашла отражение специфическая топографическая память этноса. Герои до мельчайших подробно- 
стей сохраняют облик местности, по которой они прошли, что позволяет им с уверенностью находить дорогу. Лирический герой в стихотворении А. Пичкова полон уверенности сам и успокаивает других: «Не тревожься, / Я здесь и без карты / Знаю каждый изгиб земли» (А. Пичков. «Чтоб тепло мне было...»).

Топографическая память ненцев подобна памяти других российских северных народов, а также североамериканских индейцев и австралийских аборигенов. Такое необычное развитие памяти, притом конкретной памяти, до мельчайших подробностей воспроизводящей чувственные впечатления, Леви-Брюль называл «чутьем места». «Это не какое-то социальное чувство, а чувство места, достигшее высокой степени совершенства (т. е. ставшее такой формой памяти). Тот, кто приобрел это чутье, никогда не заблудится» ${ }^{18}$. Автор изложил свое представление об особенностях топографической памяти у людей, сохранивших ее: «...пралогическое мышление вообще абстрагирует совсем не так, как наше. Условие нашего абстрагирования - логическая однородность понятий, позволяющая их комбинировать, но однородность тесно связана с одним пространством... пра-логическое мышление, напротив, представляет себе разные области пространства как качественно различные, определенные своими мистическими сопричастностями с теми или иными группами существ и предметов, то абстрагирование в том его виде, в каком мы его обычно понимаем, оказывается весьма трудным для пра-логического мышления, и мы на его месте непременно найдем мистическое абстрагирование, подчиненное закону партиципации» ${ }^{19}$. Освоенное пространство тундры Тёр из одноименной поэмы Лапцуя знает и помнит в подробностях, он близок ему, со-причастен, уверен в поддержке его. Оказавшись за пределами тундры, герой теряет эту помощь.

Одушевление пространства ненцами способствовало пониманию и запоминанию местности. Стихотворение Прокопия Явтысыя «Печора» - диалог с полноводной рекой, точнее монолог героя и предполагаемые им «ответы» реки, наполненные верой в ее связь с человеком. Вопрос о том, как река набирается силы, ординарен, как и мнение, что её поддерживают «дождей кипенье, прошлогодний звон снегов». Полноводная река получает свое богатство от окружающей природы:

Столько речек вобрала ты, Столько рыбьих, птичьих стай, Всем на свете ты богата. И богатства через край. 
Своеобразие стихотворения в том, что герой в диалоге с рекой высказывает надежду - она в ответ на доброту окружающей природы не будет грозной с человеком, поделится внутренней силой, вынесет его на берег в трудный момент. Сложным же для ненцев, в первую очередь, является то, что хотя они и живут или кочуют вблизи рек, озер, морей, они исстари боятся воды, не умеют плавать. Поэтому с водой обычно разговаривали благожелательно, относились к ней почтительно, задабривали водных духов. Описывая традиции ненцев Таймыра, Л. Ненянг писала: «Весной, когда люди после ледохода впервые сталкивали лодки на воду, особенно, когда им приходилось на ней переплывать такую махину, как Енисей (недаром же ненцы Таймыра именуют его не рекой, а морем - “ям"), самый старший в лодке говорил: “Махар лата нгэея!” (Пусть широкой будет твоя спина) Зачем это? Дабы не утонуть!» ${ }^{20}$.

Восприятие природы ненцами близко мироощущению - в прошлом - русского крестьянина, о чем, отталкиваясь от идей Платона и пытаясь понять жизнь древнего человека, его мировосприятие, утверждал Павел Флоренский:

«Вся природа одушевлена, вся - жива - в целом и в частях. Все связано тайными узами между собою, все дышит вместе друг с другом. Враждебные и благотворные воздействия идут со всех сторон. Ничто не бездейственно: но, однако, все действия и взаимо-действия вещей - существ - душ имеют в основе род телепатии, изнутри-действующе, симпатическое сродство. Энергии вещей втекают в другие вещи, - и каждая живет во всех, все - в каждой...Все вещи взирают друг на друга, тысячекратно отражают друг друга. Все вещи - центры исходящих тайных сил» ${ }^{21}$.

Многие герои произведений ненецких авторов - оленеводы, охотники, рыбаки - в силу особого мистического восприятия природы, близости к ней, к огромным пространствам обладают рядом психофизиологических особенностей, в числе которых уверенная пространственная ориентация, образное мышление, позволяющее быстро моделировать разнообразные варианты развития той или иной ситуации. Особой зоркостью и знанием пути-дороги во время кочевья отличается ясовей - проводник, указывающий дорогу аргишу - своеобразному санному поезду из нескольких нартовых оленьих или собачьих упряжек. Ясовею посвящен ряд стихотворений ненецких поэтов, его называют «вершителем чуда», умеющим ориентироваться в «бескрайней равнине» («Ясовей» В. Ледкова). 
Умение читать следы зверей, знания о повадках животных, привычных местах их обитания помогают выживанию героев в суровых условиях. Важен и эмоциональный мир. Герои таинственным образом проникают в психологию животных, угадывают их характер, охотники порой «перевоплощаются» в преследуемого зверя. Опыт поколений, запечатленный в устном народном творчестве, также помогает ненецким героям в отношениях с природой. Здесь и сцены охоты, и приметы погоды, и умение беречь окружающий природный мир. Одна из заповедей - не брать у природы лишнего, того, что не потребуется сегодня и в ближайшее время.

Неосвоенное, незнакомое пространство обживалось ненцами непросто. Выразительна картина освоения новой территории в рассказе «Про цингу». В нем Тыко Вылка, художник и «Президент Новой Земли», как называли его ненцы за организованное на острове общество ненецких жителей, приехавших с материка, с Большой Земли, описывает драму первых переселенцев. Природа острова с его скалистыми берегами не была им знакома и близка. Ненцы и ижемцы (коми) на новом месте использовали свой прежний опыт, надеялись на приметы и традиционные установки. Однако не запаслись мясом морского зверя, поскольку бездумно старались исполнить запрет церкви (священники-миссионеры обратили многих ненцев и коми в христианскую веру). Они не ели мясо морского зайца, и потому цинга погубила переселенцев. Остались в живых лишь ненецкая старушка с внучкой, потому что тайком ели мороженое мясо морского зайца. И хотя еженощно к ним приходила цинга в образе страшного существа, Некона и Некоци сумели дождаться светлых дней и случайно проезжавших мимо охотников. Спасший их человек на собачьей упряжке из-за приближающейся пурги решил оставить бабушку и внучку временно в снежном доме, чтобы после пурги приехать за ними на большей упряжке. Он сделал домик из снега, накрыл его сверху шкурами, оставил им еды. Возвратился безымянный «добрый человек через четыре дня и отвез их в большое становище».

В рассказе Тыко Вылки цинга «подкрадывалась» к героиням каждую полночь в облике тени - чудовища без туловища. Для спасения от болезни женщины использовали поверья двух религий - шаманизма и христианства. Сначала они сделали крест и отгоняли им цингу, но та возвращалась. Тогда они вспомнили древние установки шаманской веры о том, что цинга боится крови и свежего мяса, растопили в котелке кровь из мороженой нерпы, брызнули ею в лицо чудовищу и изгнали болезнь. С по- 
мощью древнего ритуала, активизировавшего силы, героини рассказа «Цинга» сумели выжить.

Освоение нового пространства, новых территорий, судя по рассказу Тыко Вылки, давалось нелегко. Для этого была необходима смекалка и находчивость, трудолюбие и активность, умение найти выход из сложной ситуации. В описанной ситуации у большей части переселенцев не нашлось лидера, не хватило здравомыслия, сообразного обстоятельствам. Помешала и привязанность к непродуманно измененным установкам.

В знакомом пространстве тундры ненцы поражают европейцев знанием местности. Будучи подростком Леонид Лапцуй «держал карту в голове», и его взяли в геологическую партию в качестве проводника. Позднее он написал ряд поэм и стихотворений о покорителях северного пространства - геологах и нефтяниках.

Поэма «Сполохи Севера» сюжетно выстроена Леонидом Лапцуем на противопоставлении традиционного и нового (индустриального) отношения к тундре. Пожилые ненцы осуждают появление разведчиков недр в их краях.

«Дыханием подземных духов» издревле считали ненцы газ, поскольку подземный мир - место обитания «злых духов древнего Ямала», которых тревожить нельзя.

Где видано,

Чтоб ненец тундру

Железом острым ковырял?

Однако к приехавшим в тундру геологам коренные жители относятся по традиционным законам гостеприимства и помощи людям, попавшим в беду. Так, командира отряда геологов Волжина, застигнутого пургой и замерзающего, спасли Вэрья и его сын Папаля, оленеводы и охотники. Они запрягли лучших оленей и отвезли русского геолога к врачам. Вылечившись, влюбленный в свое дело Волжин навещал спасших его ненцев и зародил у Папали желание стать разведчиком недр. Вэрья сердился и не отпускал будущего наследника оленеводческого дела, но упрямый юноша уехал учиться. Вернувшись, молодой человек увидел, что тундра «Взаперти хранит сокровища земные, / но он сумеет их найти!» Однако тундра встретила нового специалиста неласково, настороженно:

Его подняли знаний крылья.

И как бы с ярусов крутых

Смотрел он, 

Как аргиши плыли
В безбрежных далях снеговых.
Седым морщинистым простором
Крупою снежною пыля,
Перед его пытливым взором
Угрюмо хмурилась земля.

Еще более недружелюбно, даже враждебно встретили первого ненецкого геолога, которому Волжин доверил отряд специалистов, старые оленеводы. Они стали убеждать Вэрью, что «духи, выйдя на свободу, теперь погубят край отцов», «сын преступил закон отцов». От этих страшных предсказаний и угроз Вэрья то впадал в ярость и даже ударил однажды сына, «сломав березовый хорей», то плакал и умолял, вставал на колени перед Папалей. Он жаловался, что его обходят стороной «друзья былые», угрожал сыну:

\footnotetext{
Все ненцы проклянут навек!

Я думал:

В тундру как хозяин, а не безбожником придешь.

Своими видеть мне глазами

Твои дела -

Что в сердце нож!
}

Папаля же неистово трудился, верил в свою удачу, был вознагражден находками газовых и нефтяных месторождений. Он развил свое потомственное умение видеть и понимать тундру и перед ним открылись недра:

Он словно видел под землею, где стынет газовый туман, где нефть колышется глубоко рекою, сжатой мерзлотой...

Старики, «ловкие, как лисы», открыли на Папалю охоту. Их желание расправиться с нарушившим закон предков, было весьма кровожадным, это было решение принести жертву-искупление за нарушение обычаев:

Они за грех перед богами

Раздеть хотели донага,

Связав, поставить под ветрами

Ученого тундровика. 
Примирение с отцом и его друзьями наступило лишь тогда, когда в стойбища геологи привезли газ и свет, сделали быт оленеводов более комфортным, облегчили кочевую и начинающуюся оседлую жизнь. Цивилизация изменила прежние представления о тундре, и теперь «раскрывали тайны недра / седой, завьюженной земли».

\author{
Уже во многих чумах края \\ Горел, светя и грея, газ, \\ Уклад тундровиков меняя. \\ Открылся новой жизни пласт.
}

У ненецких поэтов и прозаиков эйфория приобщения к комфорту вскоре сменилась волнением за экологию тундры. Они стали взывать к возрождению существовавших у ненцев традиций бережного отношения к природе. В поэзии появилось осуждение немилосердного, порой безжалостного отношения нефтяников к озерам и рекам. Так, Любовь Ненянг в стихотворении «Губы шепчут “Алыкёль!..”” предупреждает: «изумрудная вода почернеет» и озеро превратится в нефтяную лужу. Юрий Вэлла в стихотворении «Здесь была сосна...» порицает бездумное уничтожение нефтедобытчиками редких в тундре деревьев а также беззаботное обращение с водоемами: нефть заливает их, и потому там «не плещется рыба» и «даже водоросли не растут».

\title{
Пейзаэс как реальное и метафизическое пространство
}

В число особенностей поэтических пейзажных зарисовок у ненцев входит их необычное восприятие, непосредственное отражение реальной действительности органами чувств. Перцептивные впечатления об окружающем мире, рождающие достоверные образы, крепко связаны с интерпретацией, составленной из свойств и отношений, которые приписываются образу на основании опыта, знаний, логики и др. Это - гипотезы о скрытых свойствах и потенциальных возможностях образа.

Снег падает,

Доверчив, нежен, звонок,

Он дымом стойбищ и дорог

пропах.

И ластится,

Ручной, как олененок,

И незаметно

Тает на губах.

(П. Явтысый. «Первый снег») 
Для лирического героя стих. А. Пичкова «Закружился белый листопад...» наступление зимы связано с исчезновением прежних путей, поскольку «снежное большое одеяло / покрывает ниточки дорог», определено необходимостью «в бездорожье отправляясь в путь» найти жизненно значимые, верные тропинки, чтобы «Старые по-новому торить, / Прежние на время позабыть».

Своей красотой и пульсирующей тайной тундра манит лирических героев. Зов пространства обретает неодолимую притягательность, пробуждает энергию, дает силы.

Я только здесь и оживаю,

Твоим, земля, живу теплом.

(А. Пичков. «Летят олени»)

Мотив «свой» как антитеза понятию «чужой» ярко звучит при описании восприятия Тёром необычных таёжных мест. Эмоциями «чужака» проникнут пейзаж тайги в поэме-сказке Лапцуя «Тёр». Тайга представляется герою сонным видением. Эстетика таежного края в восприятии «чужака» наполнена не только удивлением, но и восхищением. Метафоры, эпитеты выразительны и несут заряд бодрости и радости. Это и «дремучий лес немеряный», и сомкнувшиеся «кедры стенами, / Верхами в небо самое, - / Видать, их солнце ясное / Лучами заарканило». Стволы древних кедров «тверды, как бивни мамонта», «в живой росе, как звездочки, / Цветов сияют венчики».

В рассказе Любови Ненянг «Таймырская быль» описание природы полуострова представлено автором в соответствии с настроением и душевным состоянием главной героини. Неле вместе с маленькой дочкой Саттой живет в стойбище у богатого дяди, выполняя непосильную работу хаби, батрачки, потому что потеряла мужа во время чумы. Жизнь кажется ей не просто безрадостной, а «без надежды и просвета». Потому и все вокруг уныло и печально: груженные доверху дровами нарты скрипят, «воз дров норовит развалиться и поломать нарту». На окружающий пейзаж женщина смотрит печальными глазами. В природе все одухотворено связями, близкими к человеческим. «Редкий, чахлый листвяжник весь укрыт мохнатыми шапками снега. Холодно деревцам. Вон как беспокойно покачиваются ветки, шалый ветер не щадит их. А эти три дерева, чтобы защититься прижались друг к другу. Наверно, это семья. А может, друзья верные. Кругом снег. Мягкий и рыхлый, жесткий и колючий, ровный и бугристый, чистый, искрящийся снег». 
Когда Неле заболела, утешителем для нее стал Я-Небя - Дух земли-матери. «Я-Небя ласкала ее, жалела, грела. С нею женщине было уютно и по-особому безмятежно, словно ничего не тревожило. Зато просыпаться было горько. Часами Неле лежала с закрытыми глазами, бессильная, ко всему безразличная».

Выздоровление Неле связано с возрождением природы. Оно «...наступило в разгар весны, когда в небе уже веселились караваны гусей, когда тундра дышала свежей молодостью майского ветра». Выздоровление изменило и восприятие природы лета. «Неле стоит на пригорке, и свежий ветерок бодрит и веселит ее. Кругом тундра, тундра родная, близкая. Сотни озер... разбросаны вокруг, как лужицы после дождя». И зима с изменением жизни - выздоровлением и тайным отъездом из ненавистного дядиного стойбища в поселок - не кажется героине холодной и сердитой: «Искрится дорога, щедро улыбается солнце, олени все убыстряют шаг. На душе у Неле легко и свободно...»

\section{Звуки - часть природного пространства и ориентиры}

Художественное пространство произведений ненецких поэтов и прозаиков наполнено описанием звуков разнообразной силы и воздействия, которые имеют природно-феноменологические формы. Это и вибрирующий звон оленьих рогов, полноголосое пение и понятные лишь избранным «разговоры» птиц, хоркание оленей, многозвучный - от рокочущего и грозного до мягкого - шум моря, реки или ветра, многозначный скрип. Невидимые и неосязаемые звуки для героев как реальны, так и таинственны, наполнены мистикой, воздействуют на их психику и на принятие решений в определенной ситуации, а порой и на судьбу. Звуки являются предвестниками неожиданных событий в жизни человека.

В повести А. Неркаги «Илир» смутное мистическое воздействие звука в пространстве чума приобрело зловещую определенность, и в конце концов звук околдовал героиню Едэйне и довел ее до безрассудного поведения. Этим грозным звуком стал скрип Харбцо. Накануне свадьбы Едэйне услышала в чуме скрип. Мать объяснила ей, что это тревожное предупреждение о каких-то грядущих событиях. Искать место, откуда исходит скрип, не надо, потому что он может довести человека до безумия. И рассказала дочери легенду об охотнике, который пришел однажды домой без добычи, сильно сердился на неудачу и вдруг услышал скрип, будто бы приглашающий к разговору. Охотник долго не 
мог уснуть из-за повторяющегося скрипа, и рассердившись, схватил топор, стал рубить землю и шесты в том месте, где скрипело. Но скрип, утихнув, повторился вновь в другой стороне, а потом стал передвигаться по всему чуму. Рассерженный хозяин махал топором и гонялся за скрипом. Утром же оказалось, что он зарубил жену и детей. Харбцо «отнял у него ум». Эта легенда и услышанный скрип врезались в память Едэйне. Находясь под их воздействием, девушка, когда потеряла жениха и родителей, стала по ночам звать Харбцо, чтобы он помог ей избавиться от тяжелых мыслей, лишив разума. Дождавшись скрипа, она с топором в руках стала метаться по чуму, рубить шесты и хохотать. Утром к Едэйне вернулось обычное сознание, но она решила поддерживать созданный имидж сумасшедшей и долгие годы жила с этим имиджем, облегчавшим ее сиротское существование. Скрип кардинально повлиял на судьбу героини.

Скрип воспринимается другим героем повести «Илир» как звук, предупреждающий о недоброжелательном отношении кого-то из окружающих людей. Хозяин стойбища Майма, разгневанный поведением пастухов, навсегда уезжающих из его стойбища в колхоз, услышал тягучий скрип полозьев их аргиша. Он сразу же представил - «заслоняясь этим скрипом, как ладонью, кто-то из пастухов смеялся над ним».

Особая значимость для эмоциональной памяти героевненцев - способность звуков повлиять на их поступки - раскрыты в повести Л. Ненянг «Звон оленьих рогов». Сюжет повести построен на дихотомии «свое»- «чужое» пространство, в ней оленевод Ламдо Яптунэ с трудом приобщается к необычному для него городскому пространству. Звуки и запахи родной тундры постоянно тревожат душу молодого мужчины, разжигают сомнения в правильности выбора, «зовут и манят» в оленеводческое стойбище. Слияние с окружающим пространством, с главными для обеспечения выживания человека в тундре животными - оленями, звоном их рогов и стуком копыт произошло еще в детстве и постоянно тревожит душу повзрослевшего героя в новом пространственном мире. Повесть начинается с красочного описания открытия мира, постижения окружающего пространства мальчиком Ламдо, его детского удивления и завороженности красотой звона оленьих рогов: «Сияло солнце. Сверкали снега. Но, опустив голову, потом снова открыв глаза, мальчик не увидел уже ни снегов, ни солнца: густой лес рогов покачивался перед ним, походя на тальники, затопленные веш- 
ними водами и чуткие даже к самым тихим ветрам. Рога, покачиваясь, задевая друг друга, звучали. И сквозь этот звук, не похожий ни на какой иной, прорывался еще один, более трепетный, будто рождавшийся не где-то там, в мире, но словно поднимавшийся в самой мальчишеской душе, звеневший в ней, перестук оленьих копыт.

\section{Олени, олени, олени...}

Они заполнили все пространство вокруг. Их живая масса колыхалась, медленно двигалась, жила. И мальчик, сам того не замечая, раскинув руки, поводя ими сверху вниз медленно и плавно, как бы слился с этим движением, неторопливым и нечетким, как жизнь неохватного глазом потока. Он жил этим движением. Был частицей его».

Эти звуки периодически возвращаются и к повзрослевшему Ламдо. В сознании происходит сравнение с новым пространственным окружением, с его тонами, появляется негативное восприятие нового. Выйдя на берег реки в городском порту, Ламдо видит «серо-свинцовую хлябь Енисея», слышит его «тяжкий гул». В спокойное расположение духа героя приводят лишь воспоминания о стойбище, звуки тундры, звон оленьих рогов. «...Там слышится звон тонкой кости - рога задевают рога. И звон этот вечен, как вечен простор нескончаемой тундры. И сквозь этот звон, воздушно-трепетный, прорывается звук еще более высокий, похожий на биение сердца, на ток крови, идущий легкими толчками по жилам - перестук оленьих копыт.

Олени. Олени... Свист полоза по морозно-крупчатому снегу и миг, когда уже и свист, и само скольжение настолько невесомо, неслышно, что кажется: между полозьями и заснеженной землей - воздушная река».

Звуки, впитанные в детстве, глубоко запали в душу героя, они как бы стали родственными ему по крови. Их магическая сила вновь и вновь зовет его к оленеводам. И Ламдо в конце повести не без влияния этих зовущих звуков, а также упорного стремления отца вернуть к себе сына, а также под воздействием идей переустройства кочевой жизни оленеводов возвращается в родное стойбище.

Звуки в произведениях порой подчеркивают трагизм положения героев, их напряженное душевное состояние. Угонщики оленей привязали Егора Явтысыя (В. Ледков. «Месяц Малой Темноты») к нартам и оставили на краю обрыва. Обреченный на 
гибель пастух долго слышал «крики, свист, колкий треск оленьих ног». Позднее, когда стало невыносимо от тундрового гнуса и мошкары, ухудшилось физическое состояние, усилилась опасность гибели героя, звуки в пространстве стали для него неразличимы. Писатель использует описание их для контраста, усиления трагизма ситуации: «В ясном небе разливалось щебетанье птиц. Оглушенный своим несчастьем, Егор не слышал их песен».

Этот же прием описания многозвучного пространства как фона душевных переживаний героя, во время которых герой не воспринимает звуки, использовал Ледков в повести и при выборе решения и сомнений другого героя, хозяина стойбища Тэси: «Жадно понюхав снег, упряжные тут же принялись долбить его копытами. Поскрипывая, скользили по снегу нарты, позванивали туго натянутые промерзшие постромки. Воздух пропах душистой землей, ягелем и пряным багульником. Но Тэси было не до звуков и запахов. Он решал задачу: ехать или не ехать в Пэ-Яха? Главное, узнать, где сейчас Пета. Сам он сквозь землю не провалится, а вот отправить его туда, пожалуй, нужно. Другим будет неповадно уходить...»

Состояние влюбленности героя в девушку В. Ледков в повести «Синева в аркане», близкой к развернутому очерку, передает идиллическим восприятием пространства, его звуков: «Олени бежали, закинув рога над упругими спинами. Нет, не бежали олени - летели! Летели, как выстреленные из лука! И... то ли пересохшая земля звенела от копьев и полозьев, то ли олени трубили, наполняя резвой, как стремительный бег, музыкой простор».

Огромный безмолвный простор тундры наполняется у поэтов многоголосьем. Звуки подчеркивают и дополняют ширь пространства и эпическую всеохватность жизни. Пространство среда обитания настроений, чувств поэта - активизировано стозвучием. Л. Лапцуй предлагает читателю обратить внимание на способность ветра оживить безмолвное пространство:

Ты прислушайся. Ты слышишь: ветер шарит

Отмороженными лапами по двери.

Он потом уйдет, заохает, как странник, Пробежит по всем дорогам без разбора И закат зажжет холодными кострами, И в ложбины сядет сумрачно и немо, Звуки канут в тишину, как в воду камень. 
В поэме Л. Лапцуя «Сполохи Севера» лирический герой, скользя на нартах во время поземки, слышит звуки-«разговоры» окружающего:

\author{
Скрипят упругие полозья. \\ Откликнувшись на этот звук, \\ Подобно бубну, на морозе \\ Сугробы забубнили вдруг.
}

В этот диалог вступают и «над рогами оленей поднятый хорей», и куропатки, «сильнее хрусткая поземка запела тонкою струной».

В. Ледков в стихотворении «Ночь» заполняет тишину звуками лунных колец, спускающихся на землю и общающихся со снегом. «Звон лунных колец умолк», раскрыв доверенные небу тайны, и вновь тихо поплыла луна «лебеденком меж островов».

А. Пичков радуется своему состоянию влюбленности, и звуки помогают выразить это взволнованное состояние: «Мне шум волны, как музыка, звучит / И песня чайки - как привет любимой...» (А. Пичков. Мне шум волны, как музыка, звучит...)

Пространство тундры живописно, но порой наполнено буйством стихий, угрожающих человеку.

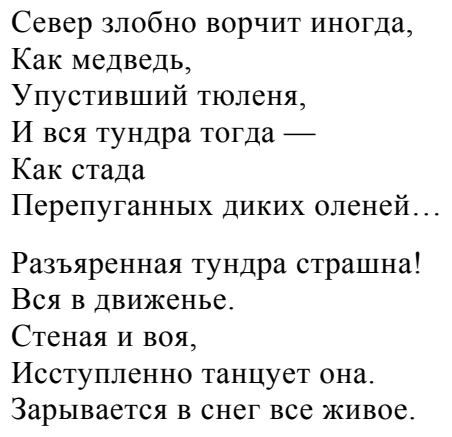

Трагедию рыбака в стихотворении Л. Ненянг «Лиственница и валун» предваряет картина внезапно нагрянувшего шторма, принесшего с собой устрашающие звуки:

И три дня и три ночи скакали

Злые волны под вой штормовой!

Прямо к небу вздымался прибой,

Разрушая прибрежные скалы. 
Поэты вслушиваются в окружающее пространство, пытаясь понять смысл, по крайней мере, трепет смысла звуков, привлекая для их раскодирования представления и опыт предков.

По приметам прадедов моих
Я скажу, какое будет лето,
И зачем внезапно ветер стих,
И о ком гагара плачет где-то.

(Л. Ненянг. «Знаю я, о чем молчит река...»)

Смысловое содержание звуков, издаваемых птицами, а также обитателями морей и рек, тундровых просторов, кажется доступным творцам литературы ненцев. Они постоянно манифестируют это читателю:

Поглядите - с птичьей песнею дружу я, На тюлений свист умею отзываться.

(Л. Лапиуй. «Аргиш»)

«Мне понятны птичьи разговоры», - утверждает в своих стихах А. Пичков.

Птицы ведут «разговоры», порой предполагаемые и угадываемые П. Явтысыем. Лебедь белая «печальным кликом» ищет когото или что-то, постоянно возвращаясь к берегу реки Неруты, и вдруг «ответным зовом / где-то хоркнули олени. / Лебедь белая, / услышав, / вдаль на зов тот унеслась» (П. Явтысый. «Лебедь белая»). Поэт слышит и распознает «скорбный крик» гагары, когда та остается «в гнезде без пары».

У ненцев активна локализация звука, связь его с местом. Нередко в фольклоре и литературе к числу специфических особенностей героев отнесена ориентация их в пространстве по звукам, умение слышать их на далеком расстоянии и распознавать, где находятся люди и животные, чем они заняты в данный момент.

Ориентация в пространстве по звукам, свойственная ненецким оленеводам, стала судьбоносной для одного из героев романа В. Ледкова «Месяц Малой Темноты». Оленевод Пета, чтобы определить для себя в темноте и звенящей тишине ночи направление движения, узнать, что происходит вокруг, нащупав ногами кочку, ложится и прислушивается. Он слышит не только звон рогов дерущихся оленей, треск их копыт, звон бубенцов, но и звук отдаленного выстрела, который он воспринимает как зов на помощь. Верный традициям жителей тундры Пета устремляется к нуждающемуся в поддержке пастуху, который не может самостоя- 
тельно вытащить тонущих в болоте оленей. Эта случайная встреча становится определяющей в его дальнейшем жизненном пути.

В поэме Ивана Юганпелика «Девушка Сихирти» ярко выражена вера автора и лирической героини не только в одухотворенность пространства, но и в его возможность и стремление «запомнить» уходящего в иной мир человека, чтобы «рассказать» о человеческой судьбе грядущим поколениям. Замерзающая у подножья горы девушка-сирота поет прощальную песню, в которой жалуется на судьбу и надеется, что скала сохранит песню и передаст ее с помощью ветра будущим поколениям. Поэт подтверждает: прошли годы после гибели девушки Сихирти, а «Песня на земле осталась, / Живая песня вьется в вышине».

\section{Стойбище и чум как профанное и сакральное пространство}

Родовое стойбище и чум - сакральные пространства, онтологически сотворяющие мир ненецких фольклорных и литературных героев. В бесконечном пространстве тундры они становятся для кочевников ориентиром и центром.

Как ограниченное пространство стойбища, так и закрытое профанное пространство чума несут двойную семиотическую нагрузку: мифопоэтическую и метафизическую.

Чувство родного очага у кочевников проявляется именно в любви к месту своего становища, выбранного когда-то предками с учетом природных условий, обеспечивающих благоприятное проживание. Ненецкий фольклор содержит немало преданий о том, как предки искали места для родовых стойбищ.

Эти легенды передаются из поколения в поколение, находят отражение в художественной литературе, в биографических очерках о жизни писателей.

Выбор родового стойбища в первую очередь связывался с возможностью выживания рода, с наличием пищи как для людей, так и жизнеподдерживающих оленей. По месту стойбища ненцы часто называли и весь род. Герой автобиографической повести В. Ледкова «Синева в аркане», объясняя происхождение своей фамилии, описывает стойбища, в которых жил его род. Сначала это было место на берегу залива около сопки. «Место это называлось Паханзедами, что в переводе на русский значит сопки у залива. По названию места соседние племена стали называть Паханзедами и людей, живущих здесь». Герой уточняет, 
почему его фамилия теперь уже не связана с Паханзедами, а имеет название другого места и стойбища. Благополучно живших в стойбище Паханзедов постигла великая беда - из-за отсутствия притока новой крови и браков между родственниками стали рождаться дети-инвалиды. Ограниченное пространство проживания, отсутствие родственных связей с дальними стойбищами сыграло роковую, разрушительную роль. И тогда старейшина, чтобы спасти род от вымирания, предложил: «И как бы ни была богата наша земля, ради спасения рода нам надо бросить ее. Ищите, Паханзеды, новую кровь себе! Нельзя брать в жены девушку из своего рода. Чем дальше найдет себе жену юноша, тем выше поднимет свой род! И в семь раз лучше, если жена будет из другого племени и языка!» Род расселился по разным другим местам, несчастливое место стойбища опустело и уже никем не заселялось. Предки героя получили новое название, откочевав в долину Большеземельской тундры. «А долина или низина по-ненецки - “лед”, маленькая - “ледко”. С приходом в тундру русских появилось слово - Ледков». Автор передал герою-повествователю и свое имя и свою фамилию, рассказал об истории переселений своего рода. Содержание помещенной в повести легенды раскрывает как особенности подбора ненцами родового места, так и мудрость, целеустремленность к выживанию предков Ледкова, их бесценный, достойный уважения вклад в дело продолжения рода, помогают раскрыть механизм воссоздания и развития пространственных представлений в культуре этноса.

Прозаики и поэты, обращаясь к описанию мест кочевий, часто используют свои детские воспоминания, поскольку многие из названных прозаиков и поэтов - Л. Лапцуй, В. Ледков, П. Явтысый, А. Пичков, Л. Ненянг - родившись в стойбищах, жили после учебы в городах. Так, П. Явтысый представляет родовое стойбище, где «отзвук детства бродит в ивах, / даль окликая без конца».

\author{
Так память, \\ сквозь года кочуя, \\ меня вновь \\ к стойбищам влечет, - \\ о, как вернуться \\ к ним хочу я! \\ (П. Явтысый. «Как девушки - нежны, красивы...»)
}


Навещая родовые стойбища, поэты видят запустение, оставленные в годы перехода к оседлой жизни родные чумовища, что рождает чувства ностальгии и горести. В стихотворении «Пепел чумовища» Петра Явтысыя лирический герой (а возможно, сам поэт, периодически посещавший родные места) возвращается в стойбище уже седым, вспоминает с грустью и детство, и юность, и родителей.

Родовое пространство как часть жизни, ушедшей в небытие, вызывает у лирического героя и улыбку, и слезы.

Наполнены необоримой тоской и сокровенной грустью о прошлой кочевой жизни воспоминания Л. Лапцуя, нахлынувшие на него при посещении родового стойбища.

\author{
Ой, тундра моя, кормилица, \\ Bce, все в тебе неизменное: \\ И реки в прибрежных зарослях, \\ И в ягеле - косогор, \\ И лишь чумовище старое, \\ Такое ж, как люди, тленное, \\ Невидящим взглядом пепельным \\ Глядит на меня в упор. \\ Сухую траву пожухлую \\ Прижали ветра ладонями \\ К земле, где шумело стойбище \\ И отчий пылал очаг.
}

(Л. Лапиуй. «Надыматься бы...»)

Наряду со стойбищем в литературе ненцев воспет чум как реальное и сакральное пространство. Являясь фундаментом бытия, чум по своему строению причастен космосу, космологическому творению. По своей форме - это круг, устремленный шестами к небу. Связь с внешним миром осуществляется через макодан отверстие вверху чума, в которое выходит дым, заглядывают солнце, луна и звезды. Он гармонизируется с природой.

В фольклоре и литературе ненцев кроме переносного чума присутствует еще и «куропачий чум» - снежный дом, который выкапывают себе попавшие в жестокую пургу путники. Так, умеющий правильно выстроить «куропачий чум» ненец Тусида спасает от неминуемой гибели отряд геологов в поэме Лапцуя «Под звездами Ямала».

Чум - мифосемиотическое пространство образа тундры. В стихотворении «Спаситель» Л. Лапцуя звучит гимн восхищения и благодарности одухотворенному переносному жилищу кочевников. 
Мой чум! Не счесть твоих столетий,

Ты на веку узнал немало -

Сплетением арканных петель

Твой путь петляет по Ямалу.

Мысленно отправляясь по пройденным чумом путям, поэт представляет трудности и беды своего детства:

Как мерз ты, вспоминаю ныне,

Чтоб мог от стужи я укрыться,

Спасал меня, как мать-гусыня,

Хранил меня, как мать-орлица.

И горбился в изнеможенье,

Когда хлестали в танце странном

Смычки ветров с остервененьем

По струнам-ребрам деревянным...

По мнению Л. Лапцуя, чум способен перенять характер и переживания его владельцев. Эта идея нашла отражение в его стихотворении «Покинутый чум». Путник с каюром останавливаются у старого чума. И этот «обросший мхом, ушедший в землю чум» привлекает внимание путника, он ощущает сложную судьбу бывших его обитателей. «Печать тяжелых, застарелых дум / на нем лежала много-много лет / и был он сгорблен, как столетний дед, / тот ветхий чум, покинутый давно, / в нем было сыро, пусто и темно». Предположения путника оправдываются. Каюр рассказывает ему трагическую историю оленевода, потерявшего семью, и в одиночестве и бедности долгие годы проживавшего в этом чуме. «Он сам на зверя стал похож обличьем: каким-то странным веяло величьем от глаз его, сверкающих огнем». Уехав из чума, старец словно передал жилищу свои тревоги и думы, свой облик.

Чум дорог ненцам тем, что символизирует стабильность существования, укорененность в этом безбрежном мире. Внутреннее пространство сакрализовано, закреплены места вокруг очага костра посреди чума, своеобразного центра. Устойчивое распределение пространства чума обеспечивает стабильность семейной жизни. Переход на оседлый образ жизни в прошлом веке постепенно менял отношение к старинному переносному жилищу.

Композиция рассказа В. Ледкова «Чум» построена на столкновении двух типов восприятия пространства «свое» - «чужое». Главный герой Игнат Вылка, старый оленевод, по просьбе внучки-архитектора приехал жить в поселок городского типа. Окружающее пространство выводит его из равновесия. Он удру- 
чен давящими на него стенами, постоянно подходит к окну, чтобы увидеть небо, но перед ним лишь кусочек между домами. Оленевод часто уходит на берег реки и жалуется на отсутствие шири и дали перед глазами: «Тесно в городе глазу». Простор тундры, где он чувствовал себя, как утверждает автор, хозяином жизни, своеобразной частью космоса, стал предметом его желаний, поскольку «грызла душу тоска по простору». Эта неодолимая тоска превратила стремившегося соответствовать своей фамилии Вылка, что значит «улыбчивый», в молчаливого и грустного человека.

В городской квартире старика удручают высокие потолки и необычно высокая мебель. Комфортно себя он чувствует лишь на оленьей шкуре в кладовке, но дочь осуждает его за желание спать в подсобном помещении. Тогда Игнат Вылка исчезает на несколько дней и возвращается с маленьким чумом, который ставит недалеко от многоэтажного дома. Его поступок и доводы в пользу многовекового жилища ненцев убеждают главного архитектора города нефтяников Куприянова построить многоэтажный дом на открытом пространстве с круговыми окнами для обзора тундры с низкими потолками и низкой мебелью, чтобы облегчить адаптацию ненцев к новому пространству. «Здание имело форму правильного конуса. От самого острия его макушки торчали вверх пучком, как шесты чума, телевизионные антенны, утолщенные у основания. От этого здание напоминало гигантский чум. Правда, чум деда Игната, уже совсем растрепавшийся, и по сей день стоял на прежнем месте, но возле огромных зданий он был настолько мал, что разглядеть его было трудно. Дед Игнат получил собственную квартиру, которая и формой, и специальной низкой мебелью - тоже напоминала чум».

Перевернув с помощью поступков и убеждений представления архитектора Куприянова о восприятии ненцами пространства, Вылка втянул его (архитектора) в свой культурный мир, добился обогащения его эстетического опыта, понимания иного мироощущения, внес вклад в изменение архитектурного облика города.

В рассказе пространство становится смыслообразующим моментом, определяющим поведение героев. Этническая специфика его восприятия легла в основу сюжета. Основная идея - психологическая адаптация ненцев в новых бытовых условиях жизни тесно связана с их вековыми пространственными представлениями, с учетом их особенностей в процессе изменения облика тундры новыми жителями Севера. Власть пространства над ду- 
шой остро ощущают ненцы - герои произведений. Им дорог простор тундры и ограниченное пространство чума.

Сюжет повести коми-ненецкого писателя Ивана Истомина «Последняя кочевка» разворачивается, как и в рассказе В. Ледкова «Чум», вокруг решения проблемы освоения нового жизненного пространства - переселение привыкших к чуму пожилых людей в деревянные дома, переход на оседлый образ жизни. Старик Ямай знакомится с новым деревянным домом, постепенно под воздействием убеждений окружающих - строителей, фельдшера, членов правления - начинает видеть какие-то преимущества этого жилья, хотя и не высказывает их вслух. Однако упрямо отказывается переходить из чума в дом.

«Зачем нам в дом переходить? - с обидой в голосе спросил Ямай. - Зайдешь в воду - умей плавать. Мы в чуме жить привыкли, а в доме совсем не умеем».

Нерешительность старика Ямая поддерживает его жена Хадане. Она, узнав, зачем вызывали мужа в правление, сначала плачет и кричит на мужа, потом старается объяснить, почему им нельзя переселяться в дом. По ее мнению, чум лучше дома, поскольку в нем есть возможность через макодан общаться с духами: «Небо видишь. Ты небо видишь, тебя добрые духи видят и слышат, когда ты у них помощи просишь. В доме жить будешь, добрые духи не будут знать, как ты живешь, чем помочь тебе. Там макодана нет, там потолок, на потолке земля. Я сама видела, как туда землю таскали. Как же тебя добрые духи слышать будут?» В число преимуществ чума Хадане относит и отсутствие в нем окон. «Ты в чуме сидишь, улицу не видишь, и тебя с улицы не видят. Злые духи, которые по земле ходят, не видят, не знают, как ты в чуме живешь. И на сердце у тебя спокойно. А в доме кругом окна, злые духи тебя будут видеть, ты их можешь увидеть - испугаешься - с ума сойдешь».

В стихотворении Прокопия Явтысыя «Последние чумы» автор считает кочевые жилища более близкими ненцам, живыми: «Поселок спит. А рядом не уснули, как сопки островерхие, чумы». Они с недоверием смотрят на новые дома, передавая в них своих хозяев, «насупились», глядя на деревянные дома, «дымами настороженно чадят». Выразительна метафора, использованная поэтом:

Вот так всегда

задумчивая старость

на юность незнакомую глядит:

то головой качает, то вздыхает, 
себя в ней ищет и не узнает и потому натужно вспоминает далекое, минувшее свое.

Пространственные отношения в произведениях ненцев служат одним из средств моделирования авторской картины мира и мировоззрения героев, при этом постоянно становятся одной из категорий этической оценки. Пространство любви и зла, гармонии и дисгармонии, стабильности и нестабильности формируется и поддерживается как авторами, так и героями. Всей душой стремится к душевной гармонии внутри себя и вокруг, например, один из главных героев повести «Анико из рода Ного», отец главной героини. Он старается проявить внимание и понимание окружающего мира, уходит от его осуждения, стремясь создать вокруг гармонию. Гармония - прежде всего любовь, когда уделяется внимание не внешним проявлениям, а внутреннему содержанию. Себеруй любит дочь, поэтому не настаивает на том, чтобы она осталась в стойбище, хотя одному ему будет трудно выживать. Он любит окружающую природу и пытается жить с ней в согласии. Это и есть настоящая мудрость - умение увидеть все в совокупности, в целостности и взаимосвязи.

Главный герой повести А. Неркаги «Илир» хозяин стойбища Майма, ориентируясь лишь на сохранение огромного стада и в связи с этим безмерной власти над людьми, стал заложником своих устремлений, неодолимого страха потерять накопленное. Страх, беспокойство привели Майму к душевному дискомфорту, к поискам виновных среди окружающих, к неоправданной жестокости. Он не может найти успокоения для души, поскольку все мысли его нацелены на увеличение и на спасение оленьего стада от коллективизации. Майма потерял чувство меры, его зараженная желанием власти душа начинает слепо подчиняться воле. Отсутствие ощущения предела породило чувство гордыни, пренебрежение к знаниям окружающего пространства, полученным от предков. Он угнал, чтобы спрятать от представителей новой власти, большую часть стада в опасные для человека и животных места и погиб. Майма не был способен вписаться в общий временной поток эволюции, изменить сознание, создать гармонию внутри себя. И как результат - разрушение пространства жизнедеятельности окружающих и своей. Сильная энергия его зла ощущается окружающими почти физически. Состояние своей души он демонстрирует поведением. Всем становится в тягость жизнь в пространстве зла, противоречащего естественной сути 
человека. Дисгармония души хозяина породила разрушающую силу - стойбище погибло.

Зло разрушительно. Пространство зла порождает негатив. Антон Пырерка в повести «Младший сын Вэдо» рассказывает о страданиях мальчика-сироты от его имени. Старуха-хозяйка не разрешает мальчику даже погреться в чуме, заставляя заготовлять хворост на морозе. От усталости и отчаяния он находит место, защищенное от ветра кустарником, ложится ничком в вырытую оленями яму и засыпает. За это хозяйка бьет ребенка колотушкой. «Старуха ушла в чум, а я остался на снегу. Лежал и думал: “Смерть легче такой жизни, Лучше замерзну, а не встану с этого места"». Один из батраков спасает мальчика и берет в чум. Но в душе у мальчика, по его признанию, впервые появилась злоба, и он стал с тех пор помнить зло. Когда же ребенок встретил доброжелательное отношение, то все вокруг стало ярким и красивым: погода - солнечной, лес на берегу Печоры синим. Когда же он оказался вместе с сестренкой в незнакомом селении (родственники отказались взять сирот с собой на новое место кочевья), и детям пришлось жить подаянием, природа, пейзаж полностью ушли из сознания мальчика.

Изменение условий жизни героев порой формирует иное, далеко не позитивное отношение к стойбищу. Анико - главная героиня повести А. Неркаги «Анико из рода Ного» - родилась в оленеводческом стойбище, но долгие годы жила и училась в городе. Приехав после длительного отсутствия к отцу, она не может принять для себя неустроенный, с ее точки зрения, быт, не мыслит остаться здесь жить, как этого хочет отец. Ее не привлекает свободное, но не обустроенное для комфортной жизни пространство. Сопоставляя сюжетно детерминированные пространства, восприятие их героями, автор раскрывает, как устойчивые геокультурные образы влияют на душевные переживания, на нравственный выбор героев.

\section{Гендерные особенности восприятия пространства}

Гендерный подход в процессе анализа художественного пространства в ненецкой литературе основан на понятии «гендера», обозначающего те культурные и социальные нормы, правила и роль, которые общество приписывает людям в зависимости от их пола. Гендерные исследования этнологов, психологов, литературоведов обычно основываются на метантропологии - учении о 
человеческом бытии в обыденных, предельных и запредельных проявлениях мужского и женского, где используется андрогинанализ, метод изучения и глубинной коррекции отношений мужчины и женщины.

Гендерную специфику художественного пространства в произведениях ненцев можно объяснить своеобразием межличностных отношений - равенства/неравенства, логики бинарных оппозиций в традиционной культуре этноса.

Сюжеты поэм и стихов, конфликтные и трагические ситуации в прозаических произведениях (стихотворение-поэма Л. Лапцуя «Каюр», поэма В. Ледкова «Снежная нора», повесть А. Неркаги «Илир» и др.) определены жесткой регламентацией, которой подвергалось пространственное поведение женщины.

В культуре ненцев существовал запрет - женщина не могла рожать в жилом чуме. Для этого она должна была поставить отдельный маленький чумик, в который был запрещен вход мужчине. Женщина рожала в этом особом, именуемом «поганым», чуме или на нарте, или на подстеленной вне чума шкуре. Если во время перекочевки жена рожала на нарте, то муж потом сжигал эту нарту, закалывал оленей, которые везли ее. После родов женщина еще долгое время считалась «нечистой». Несколько дней она принимала пищу из рук старухи, которая могла помочь при родах, затем производилось «очищение» огнем. Роженица раздевалась и переходила через разведенный огонь, надевала новую одежду и только тогда могла выполнять домашние работы. Все вещи, с которыми соприкасались женщина и новорожденный, «очищались» водой, в которой была сварена березовая губка.

В повести «Илир» ситуация с родами в отдельном чумике стала судьбоносной для главных героев повести. Мать восьмилетнего мальчика Илира соорудила себе маленький сакральный чумик недалеко от жилого чума, родила морозной ночью сына и замерзла вместе с новорожденным, отказавшись от помощи мужчин. Илир остался сиротой, и хозяин стойбища, чувствуя свою безнаказанность, подверг мальчика самым невероятным, страшным испытаниям. Перед родами, уговаривая сына не заходить в чумик, мать объяснила ему, почему не может пойти в большой чум: «Я не хочу поганить наше жилище. Тебе на охоте не повезет, зверя не добудешь и оленей от волка не убережешь. А сил... Сил будет мало, как... ну как у мышки».

Тадане, героиня повести В. Ледкова «Месяц Малой Темноты» была выдана замуж за нелюбимого, но богатого Тэси по воле от- 
ца, получившего большой калым. Во время родов в холодном маленьком чуме в стороне от стойбища она умерла. Ее любимый мужчина поклялся никогда не жениться.

В стихотворении «Каюр» Л. Лапцуя перед нами также предстает ситуация, связанная с рождением ребенка по жестокосердному обычаю - в холодном чуме, в который мужчина не имел права войти и оказать помощь. Проезжая с каюром на собачьей упряжке мимо знакомых мест в Пяковской тайге у лесных ненцев, где дольше всего сохранялись древние обычаи, лирический герой вспоминает случай, чуть было не стоивший ему жизни. Много лет тому назад он проезжал здесь. На этом месте стоял чум, из которого доносился страшный крик роженицы, а рядом с чумом:

Волком раненым, без сил
Ненец бешено метался
С воплем боли и испуга -
Как положено, у духов
Он прощения просил.

Вспомнив о своем первом медицинском образовании, путник разжег костер, растопил снег, согрел воду и зашел в чум. Все это время хозяин смотрел на нарушающего вековые законы «грозно из-под сомкнутых бровей» и, чтобы остановить приезжего, даже схватился за топор.

И пока, от пота взмокший,
Колдовал я над младенцем,
Было слышно, как хозяин
На бруске топор точил.

Не испугавшись нависшей угрозы, молодой доктор принял роды, вынес младенца и положил на колени отцу. И тогда ярость мужчины сменилась покоем.

Неожиданно каюр рассказал путнику, что именно здесь он родился, и его «пришелец спас». «Я ему обязан жизнью / И своей, и материнской...»- с благодарностью произнес юноша. Автор посмотрел на каюра «как на сына своего». Острота былой опасности вдруг вернулась к нему:

И опять кольнуло сердце Болью радостной и чистой, Но в ответ на речь каюра Не сказал я ничего... 
Освобождение от бесчеловечных и жестких традиций происходило непросто, требовало бесстрашия и воли. В основу стихотворения «Каюр» Л. Лапцуй положил реальный случай, который произошел с ним, когда он во время поездки к лесным ненцам использовал знания своей первой профессии - фельдшера, и спас погибающую женщину и ее новорожденного.

Поиск причин достаточно жестокого обращения с рожающей женщиной, когда и она и новорожденный, лишенные обжитого пространства, подвергались смертельной опасности в специально построенном маленьком чумике или на нартах, показал, что это связано с особенностями мифологического сознания ненцев. Появление на свет младенца происходит в акте «смерти» матери, метафора «рождения» есть метафора «осиленной смерти». Но так как образ «смерти» не соответствует в первобытном сознании нашему понятию смерти и отличается от него тем, что для нас смерть есть окончание жизни, а для него «смерть» - это начало обновленной жизни, то становится понятным, что как бы умершая мать в акте смерти и сама воскресает, и рождает ребенка.

У многих народов, не только северных, бытовало представление о родах как о контакте с «иным миром», когда рождение, смерть, похороны отождествлялись через общий пространственный код, семантику пути. Прохождение через родовые каналы мыслилось как загробное путешествие души. Беременная женщина становилась средоточием природных сил, хаоса.

В культуре ненцев существовало немало вещественно-пространственных запретов для женщин. Эти проявления неравноправного поведения, существовавшие долгие годы у ненцев и нашедшие отражение в литературе, подчеркивают гендерное противопоставление героев, объясняют их поведение, становятся сюжетообразующими. Так, сюжет поэмы В. Ледкова «Снежная нора» построен на основе истории, связанной с нарушением женщиной вещественнопространственных запретов. Действие в поэме начинается с того, что жители стойбища судят оленевода Вылку, жестоко расправившегося с женой. Он отвез беременную женщину в тундру и сознательно оставил ее одну замерзать. В свое оправдание Вылка приводит примеры нарушения женщиной правил поведения, которые якобы стали причиной нападения волков на оленье стадо и неудачной охоты:

Нина нарты осквернила, Перетерла все арканы, А крепки когда-то были, 
Зверь не шел в мои капканы,

Волки стадо теребили!

Брошенная на произвол «морозной злобы» женщина вырыла себе снежную нору, справилась с вонзившимся в ее спину песцом. К счастью, проезжавший мимо на собачьей упряжке ненец уже не был под влиянием древних и суровых традиций. Он отвез Нину в больницу, где она родила сына. Путь женщины к спасению поэт назвал «через столетья гигантским прыжком».

Как свидетельствуют поэты, писатели, а также этнографы, вещественно-пространственное поведение женщины в культуре ненцев подвергалось жесткой регламентации. Она не могла пересекать дорогу, обходить вокруг чума, заходить на «чистую» половину жилища, переступать через мужские вещи, подходить к «мужским» священным объектам. Женщина постоянно должна была бдительно смотреть под ноги, чтобы не переступить через предметы охоты или рыбалки. Поведение женщины определялось строго разработанным сценарием, нарушение которого могло привести к наступлению хаотической ситуации (неудачам, болезни, смерти).

У ненцев противопоставление верха (голова) и низа (ноги) соотносилось с оппозицией «чистый»/«нечистый». Поэтому не случайно женщине запрещалось, например, переступать через упряжь, запрещалось употреблять головы жертвенных животных, делать подошвы пим (обуви) из оленьих лбов. Женская одежда как атрибут «низа» считалась «нечистой», хранилась в «поганом» углу у дверей. Даже сушить ее полагалось только у дверей и невысоко вешать для просушки.

О дихотомичной гендерной дифференциации пространства пишет В. Ледков в повести «Синева в аркане»: «Женщина не должна перешагивать через вещи, принадлежащие мужчине, предметы общего пользования, посещать священные места, ходить вокруг чума против движения солнца». В этой автобиографической повести представлена ситуация нарушения запрета для женщин посещать места жертвоприношения. Главный герой повести отвез русскую девушку-фольклористку на священную гору, куда не ступала женская нога. Это место жертвоприношений на вершине сопки наполнено следами поклонения богам Ямала: останками жертвенных животных, скульптурными изображения духов, в том числе здесь без всякой охраны была и золотая фигурка особо почитаемого сядэя. Полна таинственности и сурова картина, представшая перед глазами девушки: «На берегу маленького озера, глубину которого никто не знает, из-за груды костей смот- 
рят на полдень двести деревянных человечков. На полдень же смотрят пустыми ямами глазниц рогатые оленьи черепа. У ног идолов белеют медвежьи зубы и клыки моржей».

Герой-повествователь с говорящей фамилией Ледков, совпадающей с авторской, перед поездкой предупредил приезжую фольклористку, что не все ненцы отказались от прежних установок, и если заметят ее на священном месте, могут наказать. Расправа будет в соответствии с верованиями и традициями: «Или пристрелят при тебе же твою тень на земле, или сделают из дерева очень похожее на тебя подобие куклы и на священной горе, как эта Крутая, повесят на связанных сверху, как шесты чума, хореях. Потом эту деревяшку или сожгут, или захоронят в землю, как умершего человека. Кроме того, чтобы твоя настоящая смерть наступила быстрее, зарежут в жертву богам оленя и кости его привезут на священную гору. Кровью жертвенного оленя обольют все камни, которые встретятся на пути к вершине (это природные, естественные сядэи), и всех деревянных идолов».

Девушка-атеистка не испугалась предупреждения. Весть о нарушении женщиной запрета посещать священную гору разнеслась по тундре, и старик Явтысый изготовил деревянные куклы для повешения на горе. Один из оленеводов, чтобы спасти девушку и нарушителя-мужчину от возможного наказания, проявив смелость и находчивость, разрушил планы старика.

Все пространственные элементы быта ненцев имели ритуальное значение, отражали национальную культуру, в том числе неравноправную модель поведения мужчин и женщин. Символом женщин предстает у поэтов, например, специальная женская нарта, на которой никогда не ездили мужчины. Через судьбу женской нарты Л. Лапцуй в стихотворении «Женская нарта» выразительно представляет тяжести женской доли. Не раз на женской нарте влюбленные девушки «спасались от головни» (горящей головней в старину били девушек за неповиновение, за нежелание исполнить волю отца и выйти замуж за выбранного им жениха). Порой девушки на женских нартах покидали отцовское стойбище и уезжали к любимому. Женские нарты - свидетельницы женских забот и слез.

Однако женская нарта порой вызывала восхищение поэтов, если ассоциировалась с добротой, красотой слабого пола, теплом домашнего гнезда. Отсюда сравнение ее с птицами:

Летишь ты проворнее ястреба-птицы

И в зоркости споришь с полярной совой, 
На вьюгу бросаешься горной орлицей, Птенцов своих шкурой укрыв меховой.

(Л. Лапиуй. «Женская нарта»)

По мнению поэта, женская нарта - символ женских «безгрешных помышлений / И женского сердца несметных даров», поскольку вдохновляла мужчин на большие дела: «Ты к сердцу мужскому хитро подшивала / Большие отважные крылья орла».

Как видим, отношение к женщине у ненцев дуалистическое. Она не только может нарушением запретов принести несчастье, но способна стать вдохновительницей на подвиги и источником силы для мужчин. «Бесправие» женщины в таких культурах, по мнению Фрэзера, сродни «бесправию» священного царя и имеет ту же сакральную основу: «Такой правитель живет опутанный сетями детально разработанного этикета, запретов и предписаний, цель которых состоит не в охране его достоинства и тем более благополучия, а в удержании его от совершения поступков, которые нарушили бы гармонию природы, могли бы ввергнуть его самого, народ и весь мир во всеобщую катастрофу. Как одеяние священного вождя убивает тех, кто им пользуется, так и сакрализованные мужские вещи, к которым прикоснулась женщина, опасны для жизни мужчины» ${ }^{22}$.

Существовало немало обычаев, подтверждавших и поклонение мужчин женщинам. Так, те же женские нарты изготовляли ненцы с большими удобствами, а для упряжки выбирали самых красивых, легко управляемых оленей. В ненецкой мифологии женщина выступает праматерью - прародительницей мира. Этнограф Г. А. Старцев пересказывает космогонический миф ненцев о первородности женщины, что будто бы в первоначальные времена, «когда ни земли, ни воды не было, а была только жидкая глина, Бог и черт родились от женщины, которая жила в этой тине... Когда выросли ее сыновья Нум и Гылика, по ее просьбе Нум создал две земли - белую и красную. Красную землю он подарил своей матери, и теперь она живет на ней» ${ }^{23}$.

Таким образом, в ненецкой мифологии женщина выступает матерью-прародительницей мира. Возможно, именно эти «космогонические» функции и обусловили ее особое положение в традиционном обществе. Женщина выступает как представительница сакрального мира, и от ее поведения зависят судьбы людей и всего «порожденного» ею мира. В фольклоре и литературе ненцев тундра-мать выступает как некая одухотворенная 
защитница, проверяющая людей с помощью стихии на выносливость, умение выжить, на крепость характера.

В «мифологической социологии» традиционного общества женщина занимала такое же положение, как и предки, которые, с одной стороны, могли принимать обличье «нечистой» силы, а с другой - выступать в качестве руководителей - распорядителей жизни людей.

Когда оленеводы перешли на оседлый образ жизни, пасти оленей вахтовым методом стали одни мужчины. От этого жизнь и быт оленеводов, по мнению П. Явтысыя (стихотворение «Тоска вплеталась в дождевые нити...»), стали тоскливыми, неуютными, печальными, неправильными, поскольку нарушены вековые традиции.

Над тундрой в ночь взлетал беззвучный Крик:

«В кочевье - женщину верните!»

«Очеловечение» вселенского пространства через его связь с женщиной-праматерью, с женщиной-тундрой, перенос в реальную жизнь героев гендерной дифференциации пространства, позволили авторам выразительнее представить созидательные и разрушительные способности миропорядка ненцев в далеком и недавнем прошлом.

Пространство, открываемое ненецкой литературой, это, в первую очередь реальное жизненное пространство. Природа и вещи - это бытийный собственный мир людей, освоивших это пространство, они часть его.

Модификация и трансформация пространственных представлений в литературе ненцев многоаспектна: оказывает сюжетформирующее влияние, создает композиционное напряжение, а также выводит повествование, поэзию из рационально-реалистического стиля в сферу космическую, мистическую. Художественное изображение многоликого пространства помогает раскрыть взаимоотношения внутреннего мира героев с окружающей средой, позволяет увидеть специфику национальных характеров, картину мира авторов и героев.

Концепты «время», «вечность», «хронотоп»

Процесс освоения ненецкими прозаиками и поэтами категорий художественного времени и вечности, формы «хронотоп» 
детерминирован мифологией, этнической культурной традицией, спецификой зарождения и истории этой северной литературы, письменный вариант которой возник в начале XX века и интенсивно развивался со второй его половины.

Поскольку художественное сознание ненецких авторов вырастало из бессознательного мифопоэтического мышления, в нем проявляются представления не только об упорядоченном линеарном времени, но также о циклическом, особом безграничном мифическом времени.

Миф не относится к определенному времени. Это - постоянно повторяющаяся история, вечно существующее «возобновляющееся» происшествие, как и те ритуальные празднества, с которыми связан миф. Основанием мифа является повторение - «пульсация» рождения-умирания. Мифологическое сознание старалось не знать временной длительности, дистантности настоящего, прошедшего и будущего. Год делился сначала на отрезки по сезонам зимних и летних кочевий, на два периода. Постепенно возникли названия месяцев, бытовавшие по крайней мере до середины прошлого века, которые были связаны с наиболее важными событиями в их хозяйственной жизни и явлениями природы. Время исчислялось тринадцатью лунными месяцами, например, «месяц малой темноты», «месяц начала отела важенок», «комариный месяц». Такой временной интервал, связанный с луной и именуемый годом, появился, по мнению М. Элиаде, задолго до определения солнечного года, и фазы луны - зарождение, рост, уменьшение, исчезновение и через три темные ночи новое ее появление сыграли огромную роль в выработке циклических понятий. Появились у ненцев и термины, соответствующие понятиям четырех времен года, названия же дней недели возникли в результате влияния русской культуры, в фольклоре они отсутствуют.

Как и у многих народов мира, часы ненцам заменяло солнце, по нему они определяли время суток. Мать главного героя рассказа Леонида Лапцуя «Палочка с зарубками» (напечатан в сборнике его рассказов «Камень с надписью», изданном в Тюмени в 1963 г.) оленевода Атены разволновалась, что она с мужем поздно проснулась, не подготовилась к приходу сына: «Ой, как много времени, луч солнца сидит уже на третьем шесте».

Сюжет названного рассказа построен на противопоставлении былого и нового времени, при этом старое время, его достоинства, нравственные установки, обычаи не умаляются и не унижаются. Остаются в почете честность, забота о родителях, умение 
выживать в тундре. К мысли о том, что приметы нового времени - умение считать не только по зарубкам на палочке и писать - являются жизненно важными, автор подводит героя постепенно. Сначала он рассказывает об умении Атены различать оленей, отмечать их зарубками на палочках, о его удивительной зрительной памяти. «У Атены есть зоркий друг - зрительная память. И ни один олень не отмечен им дважды». По каким же приметам узнает герой оленей? «У одного оленя передние ветви рогов, “нямда", круче задних веток. У другого “нирад”, две нижние ветки, придающие красоту морде самца, острее, чем у других. У третьего голова вскинута. А вот важенка схватила ягель, олений мох, повернула морду к Атене и смотрит на него. Атена ни одну молодку не спутает, каждую распознает, не обманет его глаз острый». Действительно, «все стадо на поясе у оленевода». Но вот приключилась беда - собака обглодала палочки. И Атене приходится вновь ехать в стадо и делать зарубки, поскольку ему надо срочно отчитаться, и он не хочет прослыть нечестным человеком. Он понимает, что если бы он умел считать и писать, он мог бы назвать или записать количество оленей по возрастам. Наблюдательный Атена заметил, что те, кто знает грамоту и счет, более мудры и часто дают другим советы. Отправляясь снова к стаду, оленевод оформляет свое решение учиться в виде загадки, которую якобы вызванивают звезды: «Что человеку приносит счастье, что дает ему радость? Отгадаешь загадку будешь хорошо жить. Будешь давать советы». Загадки являются любимым фольклорным творчеством, своеобразным образным мышлением ненцев, способствующим остроте и точности рассуждений, выбору правильных решений жизненно важных вопросов в ответственные моменты.

Солнце и луна являются мерилом циклического времени. Древнейшие первообразы солнце и луна как бинарные оппозиции света и темноты, тепла и холода, надежды и отчаяния, жизни и смерти вошли в роли главных героев в ненецкие мифы, позднее нашли отражение в легендах и сказках, героическом (сюдбабц) и бытовом (ярабц) эпосе, активно реализовались в литературе. Эти первообразы, как и другие, возникшие на заре человечества, структурировали понимание мира, пробуждали творческую активность, проявлялись в фольклоре и литературе ненцев, делая сакральное более действенным и реальным, а взаимосвязь различных эпох ощутимее. 
Солнце и луна в мировосприятии ненцев не существуют друг без друга, как женщина без мужчины. Они - муж (месяц иры) и жена (солнце - хаэр). По легенде, некий мужчина однажды, обидевшись, рассердился и бросил в воду своего духапомощника (сядая), на что тот в свою очередь разозлился и погнался за своим бывшим хозяином. На пороге чума он схватил убегавшего за ноги, тогда как за руки его успела ухватить жена. Принялись они тянуть мужчину в разные стороны и разорвали напополам. Свою (заднюю) часть сядай съел, а переднюю жена на постель бросила. Лежал муж на постели, превращаясь то в младенца, то в полувзрослого. Взяла его жена и бросила в небо. Там он превратился в Месяц, а сама она стала Солнцем. С тех пор Месяц холодный, а Солнце теплое.

В календаре ненцев сочетается лунное и солнечное время. Летом ненцы живут по солнцу (а лунные циклы служат вехами этой жизни), зимой живут по луне (исходящего от нее света достаточно для передвижений по тундре), а холодное солнце оказывается «шагом времени». Ненцы считают, что солнце и луна одни для всех миров - нижних и верхних. Для маленьких людей (сихиртя), живущих в подземном мире, они тоже светят. Земля - не препятствие. Само же солнце ненцы представляют в виде красивой женщины. Именно она решает, расти деревьям, травам, мхам или не расти. Если солнце прячется, то начинаются морозы. По представлениям ненцев, луна (ирий, иры) - плоская и круглая. Известно, что на луне есть темные пятна. Это ноги лунного человека (ирий хасава). Люди видят с земли лишь нижние конечности этого существа. Его туловище и голова находятся на другой стороне луны. Как видим, представления ненцев о светилах отражают их антропологическое восприятие мира.

Чередование фаз луны использовалось для измерения времени. Следовательно, всегда существовало возможное отождествление с воскресением. Весна следовала за зимой, цветы появлялись после морозов. Месяц вырастал в новую луну.

Мирча Элиаде отмечал эту связь с космическими событиями и мифом о периодическом создании и воскресении Вселенной.

Сопоставление временного мировосприятия ненцев с представлениями соседнего северного народа ханты позволяет увидеть их сходство и различие как в мифах, фольклоре, так и в литературе. Делая различные теоретические обобщения о причинах сходства мифических и фольклорных представлений у разных народов, 
А. Н. Веселовский в своих «Разысканиях в области русского духовного стиха» (1879-1891) сформулировал известную теорию встречных течений: «Объясняя сходство мифов, сказок, эпических сюжетов у разных народов, исследователи расходятся обыкновенно по двум противоположным направлениям: сходство либо объясняется из общих основ, к которым предположительно возводятся сходные сказания, либо гипотезой, что одно из них заимствовало свое содержание из другого. В сущности, ни одна из этих теорий в отдельности не приложима, да они и мыслимы лишь совместно, ибо заимствование предполагает в воспринимающем не пустое место, а встречные течения, сходное направление мышления, аналогические образы фантазии. Теория "заимствования" вызывает, таким образом, теорию “основ”, и обратно...» ${ }^{24}$ Циклическое, мифопоэтическое время было характерно для восприятия как у ненцев, так и у ханты. Сходство двух представлений о времени как у ненецких, так и хантыйских авторов обусловлено не только художественным замыслом, но и той картиной мира, в рамках которой они творят, а также пребывают их герои. Виды и формы этого времени не фиксированы и обладают подвижностью. Так, для измерения времени у обоих народов использовалось чередование фаз луны. Следовательно, постоянно присутствовало возможное отождествление с воскресением, весна следовала за зимой, цветы появлялись после морозов, месяц вырастал в новую луну. Существовала тесная связь с космическими событиями и мифом о периодическом создании и воскресении Вселенной.

Ненецкий эпос, как и сказки, не знает предела во времени. В эпосе действие начинается в неопределенном прошлом, останавливается, возвращается назад чаще всего без всякого признака надвигающегося тревожного момента: «С тех пор, как я себя помню, мы живем на берегу озера с семью мысами», «Когда поспело варево, на улице, возле чума, послышались шаги», «Так иду я вперед целую зиму», «Дней семь иду я к холмику», «Живем мы и вот однажды днем», «Через один-два дня», «Долго ли так живем, не припомню» (эпическая песня-сюдбабц «Три Хэно»).

Время характеризовалось замкнутостью, однонаправленностью, было соблюдением реальной последовательности событий, постоянным обращением к вечному как у ненцев, так и у ханты. «Время своим чередом идет. Зима кончилась, весна прошла, лето миновало, осень с дождями новой зимой сменилась. Ими-Хиты охотится, не далеко и не близко от дома уходит, добычу бабушке 
несет», - читаем мы в хантыйской сказке «Как Ими-Хиты на санках катался». «Уходило лето, приходила осень. Уходила зима, приходила весна. Все шло свом чередом - промышляй зверя и лови рыбу», - пишет Е. Айпин в романе «Ханты, или Звезда Утренней Зари».

Созданная Леонидом Лапцуем поэма-сказка «Тёр» в духе эпических произведений - сюдбабц - отражает восприятие времени автором, намеревающимся написать историю своего народа и мысленно выстраивающим цепочку линейного невозвратного времени, и представления о времени мифологическим героем, время которого архетипично: по воле автора он постоянно умирает и возрождается. Поэт выстраивает цепочку линейного времени, начиная от обрушившегося морского ледника, когда Карское море надвинулось на сушу и покрыло ее ледяным панцирем, и стала «подобна нарте брошенной земля». Воспроизводя на большой сюжетно-пространственной площади историю народа от ледникового периода до двадцатого века, Лапцуй органично вплетает в сказочную первооснову историко-литературные материалы и историческое реалистическое повествование. Время произведения включено в широкий поток событий, развивающихся на фоне разных исторических эпох, - вплоть до семидесятыхвосьмидесятых годов XX века. В это историческое время автор вписывает главных героев с мифологическим сознанием времени. Лапцуй нередко передает временные представления через пространственные, использует форму хронотопа.

Определяя аксиологию и происхождение сюжета в повествовательных формах, Ю. М. Лотман связывал этот процесс с изменениями восприятия потока времени в сознании человека, с развитием упорядоченности видения мира:

«Сюжет представляет мощное средство осмысления жизни. Только в результате возникновения повествовательных форм искусства человек научился различать сюжетный аспект реальности, то есть расчленять недискретный поток событий на некоторые дискретные единицы, соединять их с какими-либо значениями (то есть истолковывать семантически) и организовывать их в упорядоченные цепочки (истолковывать синтагматически). Выделение событий - дискретных единиц сюжета - и наделение их определенным смыслом, с одной стороны, а также определенной временной, причинно-следственной или какой-либо иной упорядоченностью, с другой, составляет сущность сюжета» ${ }^{25}$. 
Развитие действия в поэме «Тёр» осуществляется по-сказочному, или, как в эпосе, легко, с «малым сопротивлением среды» (Д. С. Лихачев), когда время убыстряется, а пространство расширяется. Мотив пути-дороги, пространственные перемещения героя с целью приобретения знаний о мире закаляют героя нравственно. Художественное время поэмы по своим характеристикам имеет сходство со сказочным и эпическим временем. Оно безгранично, бесконечно, построено по особым законам. Перемещается герой, как и персонажи волшебной сказки, в кратчайшие сроки. Путь его «смертей» и «воскресений» - способ приобретения магической силы и знания, прием посвящения в шаманы.

Время - своеобразный образ вечности, т. е. ее подвижная «икона».

Вечность мыслилась ненцами как сфера универсального синтеза, прежде всего человека и природы, что определяло вечность как сферу добра, красоты, истины, как сферу гармонии. Время также как бы вносило разлад в основополагающие начала бытия, изолируя явления, сопоставляя их, оно порождало конфликтность, дисгармонию. Возникающие во времени зло, ложь, безобразие становились субстанциями, свидетельствующими об относительности вечных истин. Но время не отменяло вечность, существующую параллельно как сферу непознанного. С помощью ритуалов ненцы пытались уничтожить дисгармонию и вернуться в вечность, начав «чистое» время, безгрешное. Своеобразной временной границей была церемония инициации молодых людей, выразительно представленная и в ненецком фольклоре, и в литературе.

Художественная вечность не предполагает имен, в ней отражается циклическое движение времени, связанное с изменениями в природе «из века в век», следование установленным традициям и законам, исполнение которых - предназначение вечности. Величественный поток времени уравнивает малых и больших, сильных и слабых, значительные события и незначительные, содержательные и несодержательные моменты действительности.

Проблема вечного, вневременного входит в само существо мировоззрения ненецких писателей и поэтов.

Начиная свой роман «Месяц Малой Темноты» (продолжение «Люди Большой Медведицы»), В. Ледков прошлую жизнь ненцев описывает, свернув время до понимания его предками. В их сознании неизменными и вечными являются, как солнце и звезды, перекочевка с зимнего пастбища на летнее, обычаи, тради- 
ции, моральные установки, вписанные в вечность: «так было из века в век и, казалось, так будет всегда». Вечность, неизменность всего сущего как ощущение миропорядка ненцами многократно подчеркивается автором и в дальнейшем повествовании.

Отказ от вековых традиций оборачивается трагедией для героев романа. Конфликт строится на нарушении законов вечности.

Идея второй части романа Ледкова под названием «Люди Большой Медведицы» - сложный путь преодоления в сознании ненцев векового закона, связанного с покушением на жизнь человека. Убийство человека считалось тяжелым грехом, нарушающим извечный нравственный закон, который соблюдался еще и потому, что сложные условия выживания в тундре обязывали бережно относиться к жизни любого человека. Ненец в переводе на русский — человек; посягательство на жизнь другого человека, убийство, независимо от причин, автоматически выводит совершившего это злодеяние из разряда людей, поскольку он становится разносчиком «дурной крови». Он обречен на одиночество, изолирован от человеческого сообщества.

Главный герой романа «Люди Большой Медведицы» Пета Пырерка в жестокой схватке с напавшим на него бывшим хозяином Тэси убил его. С этого времени он становится изгоем, отверженным, жить рядом с которым и общаться с ним не хотел никто, даже близкий друг. И только потому, что рядом с ненцами появились люди с другими традициями и нравственными представлениями, в сознании оленеводов возникают сомнения в правильности их отношения к герою. Так, жители тундры волнуются за жизнь тяжелораненого Петы, пока он лежит в больнице. Но когда он выздоравливает, они, повинуясь вековому порядку, относятся к нему настороженно, боятся общаться с ним, объезжают его стоянку, даже если им хотелось бы согреться и отдохнуть.

Автор мастерски выстраивает развитие событий на определенном, весьма длительном отрезке времени. Эти события постоянно находятся под незримым влиянием вечности. «Сворачивая» близкое прошедшее время до двадцати лет, Ледков показывает, что вечное сильнее новых установок, сильнее логики: «Вот уже 20 лет оленьи упряжки мчатся в обход его чума». Пету «прокляла земля всех четырех тундр».

Преодоление страха перед нарушением вечного порядка, осознание возможности иной оценки случившегося происходит постепенно и с трудом. Наиболее ярко это проявляется в описании мучительных тревог и беспокойных раздумий близкого дру- 
га Петы, Вавлё Лаптандера. Вавлё был на фронте, где показал себя как меткий стрелок, «гасил» жизни многих незнакомых ему людей, врагов, но не задумывался, что должен нести за это ответственность. Оказавшись снова в привычных условиях жизни, Вавлё не может переступить закон вечности и относится к Пета как к изгою. Периодически он пытается выстроить логическую цепочку рассуждений в пользу друга, пробует поставить себя в идентичные условия. Он даже приходит к выводу, что сам поступил бы так же, но преодолеть страх перед нарушением закона вечности не может.

Многолетнее неприятие друга начинает таять только после того, как Вавлё Лаптандер оказывается перед лицом смерти, а Пета его спасает. И тогда, смущенный, с чувством вины за прошлое, Вавлё приглашает друга заехать в гости.

Своеобразно поведение самого пострадавшего от бойкота окружающих, оно не агрессивно, лишено чувства обиды. В беседе с русской женщиной, врачом Мариной, резко осуждающей и отрицающей вековые традиции, призывающей «ломать» старые законы, Пета мысленно возражает, считая, что «сам-то по себе закон этот правильный, он охраняет человека».

Марина также пострадала от установленного в веках миропорядка ненцев. Жители поселков и стойбищ встречали ее с опаской и страхом наказания за общение с ней, потому что она выздоровела и считалась «ожившей из мертвых», «а от бывших мертвецов ничего хорошего ждать не приходится». Марину отвезли далеко в тундру и оставили замерзать. Спасли женщину случайно проезжавшие мимо оленеводы.

В отличие от Петы, Марина не понимает и не принимает вековых традиций ненцев, поскольку воспитана в условиях иной культуры.

Устройство мира, нравы и многое другое казались ненцам, как и хантам, неизменными, навеки установленными. Постепенно время отвоевывало и подчиняло себе все более крупные участки в сознании людей. Так, стремление весь мир воспринимать через время и во времени выразительно отражено во внутренних монологах Демьяна, главного героя романа Еремея Айпина «Ханты, или Звезда Утренней Зари». Субъективное восприятие времени в романе изображено в тесной связи с течением времени. Прошлое, настоящее и будущее представлено в различных сочетаниях. Таежный охотник Демьян много размышляет о прошлом, анализирует настоящее и ближайшее будущее. Далекое 
будущее ему почти неподвластно. Зачастую он не понимает логики происходящего, нарушившего традиционное движение жизни во времени, и потому не может осознать перспектив.

Завязка романа «Ханты, или Звезда Утренней Зари» основана на внимании Айпина к временной категории как одной из важных составляющих поэтики. Автор свободно движется в своем времени, начинает роман с конца, разрушая при этом объективный ход времени:

«В самое последнее мгновение, когда все будет кончено и останется лишь единственный шаг в этой жизни, и житель Земли Нимьян (Демьян) из рода Медведя поймет, как непросто быть человеком и как непросто быть звездой, он вспомнит, как три дня назад, на рассвете, старый пес Харко тягучим воем разбудил его».

Согласно вековым наблюдениям хантыйских охотников, поведение животных определено временем суток. Нарушение же привычного порядка вызвало у охотника тревогу, поскольку на востоке уже взошла Звезда Утренней Зари, предвещающая то, что скоро начнет светать, и, следовательно, вой уже нельзя было отнести к ночному. Беспричинный протяжный вой на утренней заре был плохой приметой. Поселившаяся в душе Демьяна тревога пронизывает произведение, создавая напряжение и интригу. Как видим, сюжетное время действия романа короткое - три дня, но за эти дни произошли судьбоносные события, последствия которых не поддаются осознанию Демьяна, он по-прежнему не хочет верить в победу зла в человеческих душах, не может допустить в свою душу разочарование в людях. В романе превалирует внутренний монолог героя. Именно субъективное восприятие времени стало одной из форм изменения действительности, приемом раскрытия психологии героя.

Время в романе представлено автором почти осязаемо, материально. Движение светил мифологизировано, оживлено: «На востоке, над вершинами сосен, светилась Звезда Утренней Зари. Она медленно поднималась в сумрачное небо. Поднималась и тянула за собой грядущий день. Казалось, день упирался, не хотел идти на землю, но настойчивая звезда и не думала оставлять его в покое где-то за темным горизонтом. И тому ничего не оставалось, как последовать за Звездой Утренней Зари. Или: «Печальное зимнее солнце кое-как поднялось до верхушек сосен. В желто-золотистых ветвях и в светлой зелени игл бледными нитями запутались лучи-руки солнца. Вскоре они ослабнут, и небесное светило поспешно начнет свое движение вниз». 
Наглядно проявляется одно из свойств мифологического времени - неразрывность с окружающим миром, с природой, вещами и даже подчиненность им, поскольку время есть обобщенно-родовое понятие, а, следовательно, тоже живое существо.

Существует еще один способ осознания и отсчета времени, который носит название дискретного (прерывистого), когда течение времени рассматривается как колебательное движение, а определенные временные отрезки выделяются в зависимости от насыщенности событиями. При этом создаются большие дискретные «участки» времени.

Дискретное время наиболее ярко нашло отражение в эпосе и литературе, где отражаются «превратности» определенного исторического времени в жизни этноса. Существующие же в пространстве и времени, контактирующие друг с другом этносы творят историю.

Временные координаты отмечались осознанием того, что у человека есть отцы и деды, будут дети и внуки. Главный герой повести Анны Неркаги «Анико из рода Ного» озабочен продолжением рода, стремлением передать священную фигуру покровителя рода своей дочери, которая живет другими заботами и, устремившись в будущее, не хочет отягощать себя мыслями ни о своем роде, ни о предках. Отец Себеруй будущее, как и прошлое, связывает с близкими людьми, представителями семьи или рода. Страх одиночества лишает его витальных сил, о чем свидетельствуют изложенные повествователем мысли Себеруя: «Умерли жена и дочь. Значит нет ни прошлого, ни будущего. Если у человека нет будущего, он опирается на прошлое и этим живет. И вдруг темно и впереди, и сзади. Как и для чего жить дальше?»

Мифологическое время подчинено законам мифопоэтического мышления и объемлет предвечное время. Все и вся, созданное на небесах и на земле, находится в потоке этого времени. Оно не имеет ни начала, ни конца и постепенно становится цикличным. Такой интерпретации времени способствовали календарные ритуалы, связанные в первую очередь с природным круговоротом. В ненецкой литературе отразился процесс изменения представлений о времени, когда оно стало двигаться уже не по кругу, не по спирали, а только прямо, устремлено в будущее. Такое время приобретает категорию безвозвратности.

Время - не только существенная компонента нашего внутреннего опыта и ключ к пониманию истории человечества, это также ключ к пониманию природы. 
Своеобразие восприятия разного времени суток нашло яркое отражение в рассказе Е. Сусой «Когда луна сменяет солнце». В основу сюжета положено описание одного зимнего дня Большого Темного Месяца (декабря) в жизни оленеводческого стойбища. Короткий световой день начинается задолго до рассвета, с момента, когда пастух пригоняет оленей к стойбищу, чтобы мужчины могли на нескольких нартах отправиться за топливом - кустами ольховника. Е. Сусой выразительно изображает наступление нового времени суток, которое зримо отпечатывается в сознании жителей тундры. «За нартами бежит рассвет, он садится на рога оленей, на одежду, на дорогу, на снега вокруг, разгоняет тени, нависшие над зимней тундрой». Время в рассказе существует как нечто одушевленное. Рассвет - живое существо, как и солнце, которое вечером «подтянуло к себе лучи», и фиолетово-розовая заря, и сыплющая искры Полярная звезда.

Авторская концепция времени накладывает отпечаток на эстетическую природу художественного произведения, с ней связано повествовательное время, сюжетное и другие формы художественного времени.

Временные представления автора, раздумья о вечности, времени и быстротечности его для человека легли в основу развития сюжета рассказа В. Ледкова «Нарты жизни». Писатель пытается отделить циклическое время от бытийного времени жизни человека. Циклическое время предстает перед нами как неизменное, вечное. Смена времен года происходит с постоянными изменениями в природе. Несменяемы, по мнению повествователя, и традиционные занятия ненцев. «Через все века, скрипя, ползут аргиши. И так было всегда». Автору кажется неизменной и тишина тундры: «А здесь, в тундре, тихо. Все так же ярко, как всегда, сияет на небе луна, тихо качаются звезды - их не больше и не меньше, да беззаботно бродят по пастбищам молчаливые олени». Рассказывая о военном времени в тундре, писатель вновь подчеркивает стабильность традиционного уклада: «...жизнь в стойбищах тундры течет своим неизменным руслом. Все так же, в облаках пара, носятся оленьи упряжки, все так же лениво ползут аргиши, скрипя полозьями. Жизнь не стоит. Идет и время».

Время воспринимается писателем как некая отвлеченная субстанция, движущаяся параллельно с человеческим бытием, подгоняя человека к завершению земного пути, оно выразительно определяет и предопределяет все события, происходящие в рассказе. Действие развивается на постоянном сравнении нового и 
старого времени, на изменениях в традиционном образе жизни, происходивших в двадцатом веке. В соотнесении с детерминированной (обусловленной, определенной) жизнью вечность и бесконечность приобретают особый ценностный смысл.

Художественное время, которое является составляющей художественной изобразительности, отражается и на формах изображения процессов действия, и на длительности перехода от одной точки зрения к другой, и на становлении образов. Время в повести А. Неркаги «Анико из рода Ного» выступает живым участником происходящих с героями событий. В миг отчаяния, после того, как узнал о гибели жены и маленькой дочери, Себеруй словно выпадает из времени, не ощущает его: «От него отошло все: и люди, и время, даже он сам, остался один крик. Ужасный, разрывающий душу. Крик сердца».

Время связывается с физическим телом, а поскольку герой не ощущает тела, его страдающая душа попадает в безвременье. Это разновидность хронотопа шаманизма.

Конфликт между главными героями повести обостряется столкновением двух типов мировосприятия, двух хронотопов. Анико живет в современном, типичном для жителей города ритме, где время определяется общепринятым метрическим измерением. Оно насыщено разнообразными событиями, связанными с занятиями в институте, с работой, развлечениями. По утверждению повествователя, мысли о том, что можно будет съездить к родителям и «получить прощение за то, что в жизни по-прежнему много суеты и мало времени для любви», посещают ее редко, но появившись, успокаивают, снимая ответственность перед родителями.

Ее отец Себеруй и жители стойбища живут по законам мифического, циклического времени, меняя два раза в год место проживания, чтобы себя обеспечить пропитанием, продолжить жизнь рода.

Как ненецкие, так и хантыйские авторы наделяют героев особой чувствительностью к «колебаниям времени», отмечают, что каждое время у них имело свою окраску - темную или светлую. Отсчет времени обычно начинался с какого-либо значительного события. Вспоминая прошлое, старики не просто оценивали закончившийся век, но и предсказывали начало нового века. Это мог быть век удачи и благополучия, или век горя и страданий. Продолжительность века не составляла установленных линейным временем сто лет и зим. Время для ненцев, как и для ханты - это не чистая длительность, а в первую очередь сам поток 
событий и цепь поколений. Чаще всего они обходились без специального термина времени, а говорили просто о будущем, настоящем и прошлом. Прошлое для них - это не обилие цифр вроде тысячелетий или веков, а конкретные события, поступки определенных людей, предков, прожитая ими жизнь.

Многообразие субъективного восприятия времени в повести Анны Неркаги «Анико из рода Ного» и в романе Айпина «Ханты, или Звезда Утренней Зари», например, достигается благодаря различным связям фактических, происходящих в ходе развития сюжета, и восстановленных памятью событий - причинноследственным, психологическим, ассоциативным.

Выстраиваемые авторами цепочки представлений, возникающих в сознании героев, синтезируют жизненные связи. Подчеркивается контраст между «внешним» и «внутренним» временем. Одно, порой незначительное, внешнее событие дает толчок для таких представлений и цепочек представлений героев, которые покидают настоящее время события и свободно движутся во временном измерении. При этом видима тесная взаимосвязь между временем, как его использует писатель, и «многосубъектным» изображением сознания. Иные представления, возникающие в сознании, совсем не привязаны к настоящему времени внешних событий, служащих их побудительной причиной.

Все происходило в мифическом времени, воплощало коллективный проверенный опыт и потому становилось образцом для подражания, предполагалась передача этого опыта последующим поколениям в виде мифов и обрядов, чтобы они освоили систему ценностей и нормы поведения, способствующие преодолению хаоса и подготовке к преодолению стихийных сил природы. Символом времени жизни в повести Неркаги «Белый ягель» является мужской пояс, который герой Пэтко снял с себя, осознав, что пришло время, когда «сама жизнь» стала уходить от него и ее уже нельзя, как в детстве «погнаться и догнать». Выполнение этого ритуала тяжело дается впервые взглянувшему на себя со стороны и увидевшему свою беспомощность и ненужность герою - уехали в далекие края и не вспоминают о нем две дочери, умерла жена, не стало сил заботиться о чуме и еде.

В размышлениях и действиях героя автор представляет мифологемы жизни и смерти, рассматривает жизнь глазами героя как некую сущность бытия, определенную, ограниченную движущимся, судьбоносным временем. Подводя итоги, Пэтко не просто вспоминает жизненные эпизоды, а воспринимает их как 
животворную судьбу, мысленно представляет людей и прощается, не позволяя себе никаких обид. С помощью обращения к былому и настоящему времени герой пытается облегчить свое видение трагического положения.

Стойкость, выдержка, сдержанность в проявлении эмоций, типичные для ненецкого мужчины, проявляет герой в экстремальной ситуации самоопределения себя на время подготовки к уходу из жизни, период полного угасания надежд. Даже снятый им и положенный на нарту, чтобы больше уже не быть востребованным, тяжелый пояс «устало звякнул цепями, будто вздохнул».

В своих раздумьях о прожитой жизни герой повести пытается вписать ее в круг постоянного жизнетворения, отмечает вехи своей жизни как вклад несменяемого круговорота, в котором есть время жить и время уходить из нее. Автор поддерживает героя, вкладывая в его внутренний монолог традиционные установки, взятые из жизни и легенд.

Обращение к необратимому и «устойчивому» времени устных и письменных творений ненцев помогает более глубокому пониманию конкретных произведений эпических жанров и типологии многих художественных явлений в литературных произведениях. Вплетая в ткань произведений прошлое время из жизни народа или жизни героев, ненецкие авторы стремятся использовать его благотворное влияние на судьбу героев, найти в прошлом энергию для преодоления трудностей, закалить волю, укрепить характер.

Любовь Ненянг в повести «Таймырская быль» включает сказку о храбром юноше Наны, который воевал за возвращение солнца людям. Героиня повести, бедная вдова Нене, вместе со своей дочерью попала в полную зависимость от обещавшего ей хорошую безбедную жизнь дальнего родственника. Чимга Яптунэ и его жена Вэваконе превратили ее в хаби, батрачку. Обращаясь к прошлому времени, к сказочному герою, Нене старается обрести надежду на выход из беспросветной действительности.

Герои произведений ненецких авторов проживают порой за несколько часов, дней, недель или месяцев целую жизнь. Такая концентрация биографического времени становится возможной благодаря «психологизации» времени: переживания прошлого и будущего как настоящего, стягивания субъективного всех временных пластов в настоящее время.

Художественно познавая жизнь, воплощая внутренний мир героев, северные поэты и прозаики осуществляли связь пространственно-временных отношений, используя особенности хронотопа 
для создания образов. В стихотворении «Безымянный мальчик» Леонид Лапцуй создает образ отважного юноши, оказавшего помощь попавшим в экстремальную ситуацию рыбакам, которые не могли выйти в море, потому что на винт глиссера намотался трос. Все попытки ликвидировать аварию оказались бесполезными, поскольку никто не был способен выдержать пребывание в ледяной воде. Природа как бы подсмеивалась над их беспомощностью: волны, забавляясь, швыряли в лица рыбаков ледяные брызги «словно в каверзной игре». Неизвестный юноша прыгнул в ледяную воду, чтобы распилить трос ножовкой. Время, в течение которого, с одной стороны, был на краю гибели юноша, а с другой, - решалась возможная победа над стихией и дальнейшие действия людей, показалось всем присутствующим невероятно долгим, растянутым: «минуты через две, а это, право, вечность, когда вода не сводит руки, но рвется погасить живое сердце, отважный отрок над водой возник». Растянутость времени выразительно представила реакцию людей на поступок юноши, волнение за его жизнь, высветила значимость отважного поведения неизвестного героя, тут же покинувшего берег. В стихах и прозе ненцев не раз поэтизирована с помощью хронотопа способность ненцев сокращать время поисков выхода из сложной ситуации, преодоления пространства, чему способствовала особая зоркость героев, их точная ориентация в пространстве. Отмеченное явление - свидетельство неразгаданности творческого процесса. Так, Д. С. Лихачев в «Очерках по философии художественного творчества» писал, что творец, имея дело со временем и явлениями, представшими ему во времени, «преодолевает время», предугадывая последующее. «У меня ощущение (совершенно необязательное), что творимые художником персонажи воплощают в мире что-то существующее вне художника и художником только угадываемое и осуществляемое» ${ }^{26}$.

Обращение к пространственно-временному континууму как одной из составляющих мифопоэтическую картину мира в литературе ненцев и других народов Севера - методичный шаг к разгадке таинства содержания, предназначения создаваемой авторами своеобычной художественной действительности.

${ }_{1}^{1}$ Борев Ю. Эстетика: Учебник. М., 2002.

${ }^{2}$ Бахтин М. М. Эпос и роман. СПб., 2000. С. 10.

${ }^{3}$ Бахтин М. М. Тетралогия. М., 1998. С. 155. 
${ }^{4}$ Пошатаева А. В. Литература народов Севера (Истоки. Становление. Развитие). М., 1988.

${ }^{5}$ Шпенглер О. Закат Европы. Т. 1. М., 1993. С. 327.

${ }^{6}$ Топоров В. Пространство и текст // Из работ московского семиотического круга. М., 1997. С. 457.

${ }^{7}$ Гумилев Л. Н. Этносфера: история людей и история природы. М., 1993.

В книгу включен словарь понятий и терминов теории этногенеза, составленный учеником Л. Н. Гумилева В. А. Мичуриным и отредактированный автором книги. В него включен термин месторазвитие: «Месторазвитие (или родина) этноса - неповторимое сочетание ландшафтов, где данный этнос сложился как система. Характер этих ландшафтов оказывает глубокое влияние на облик этноса, определяя его адаптацию в среде».

8 Лосев А. Ф. Самое само: Сочинения. М., 1999. С. 230.

9 Шпенглер О. Закат Европы // Философия истории. Антология. М., 1995. С. $158-186$.

10 Замятин Д. Н. Гуманитарная география: Пространство и язык географических образов. СПб.: Алетейя, 2003. С. 51.

Обоснование взгляда содержит ссылку на гештальт-психологию: Веккер Л. М. Психические процессы. Л., 1974. Т. 1. С. 32.

${ }^{11}$ Пушкарева Е. Т. Миф-сказка в фольклоре ненцев: историческая типология и этническая специфика. Реферат канд. дисс... ист. наук. Л., 1983.

12 «Антропоморфизм» («человекоподобие») - уподобление человеку, наделение человеческими свойствами окружающую природу, животных, предметов, явлений природы. Располагая небольшим количеством знаний, человек стремился строить представления об окружающем исходя из знаний о себе. Ощущая в себе, внутри тела, некую жизненную силу, человек представлял себе «дух в виде какого-то существа (чаще всего человекоподобного), то ли в виде неопределенной формы облака. Но как бы то ни было, дух также наделялся жизнью и всем, что ей присуще (в том числе и какой-то телесностью)». (Кармин А. С. Культурология. СПб., 2001. С. 325).

А. С. Кармин, опираясь на исследования Л. Леви-Брюля (Леви-Брюль Л. Первобытное мышление. Л., 1930), отрицает влияние анимизма как религии, возникшей позднее, на появление мифических образов богов, животных, предметов), которые наделены жизнью, одушевлены. Цитируем сноску из книги Кармина на с. 325: «Поэтому нельзя согласиться с идущим от крупного этнографа XIX в. Э. Тайлора взглядом, что первобытному человеку изначально был свойственен религиозный анимизм (от лат. anima - душа), предполагающий веру в существование бестелесной и бессмертной индивидуальной души человека. Первобытный человек не был тайлоровским “философом-дикарем”, ясно различающим “две принадлежащие ему вещи: свою жизнь и свой призрак (душу)". Анимизм - а следовательно, и религия появляется лишь на поздних стадиях развития архаических культур».

${ }^{13}$ Путешествие Александра Кастрена по Лапландии, Северной России и Сибири (1838-1844, 1845-1849). М., 1860. С. 130.

${ }^{14}$ Хомич Л. В. Ненцы. СПб., 1995. С. 209.

${ }^{15}$ Там же. С. 208. 
${ }^{16}$ Юнг Карл Густав. Душа и миф. Шесть архетипов. М., 2005.

17 Фрэзер Дж. Золотая ветвь. М., 1980. С. 10.

18 Леви-Брюль Л. Сверхъестественное в первобытном мышлении. 1999. C. 93-94.

19 Там же. С. 101.

${ }^{20}$ Ненянг Л. Слово о фольклоре Таймырских ненцев // Полярная Звезда. 1978. № 1. С. 98.

${ }^{21}$ Флоренский П. А. Сочинения: В 4 т. Т. 3 (2). М.: Мысль, 1999. С. 151. ${ }^{22}$ Фрэзер Дж. Золотая ветвь. М., 1980. С. 197.

${ }^{23}$ Старцев Г. А. Самоеды (неница): Историко-этнографическое исследование. М.;Л., 1930. С. 114-115.

${ }^{24}$ Веселовский А. Н. Разыскания в области русского духовного стиха. СПб., 1889. Вып. 5. С. 115-116.

25 Лотман Ю. М. Происхождение сюжета в типологическом освещении // Лотман Ю. М. Статьи по типологии культуры. Тарту, 1973. С. 40.

26 Лихачев Д. С. Очерки по философии художественного творчества. СПб., 1999. С. 19. 


\section{Глава 2}

\section{ПЕРВООБРАЗЫ - ИСТОК МИФОПОЭТИЧЕСКОЙ КАРТИНЫ МИРА}

Символические первообразы (архетипы) ${ }^{1}$ восприятия окружающего мира и себя в нем ненцами и другими народами Севера, художественно развернутые в их литературах, - золотое звено в цепи, соединяющей времена. Их исток в мифологии. Именно мифология, по Аристотелю, определяет суть, т.е. начала или первичные принципы, хотя ответ на вопрос «почему» она не дает. В своей работе «Душа и миф. Шесть архетипов» К. Юнг утверждал, что эти первичные субстанции или первичные состояния никогда не стареют, никогда не могут быть превзойдены и производят все и всегда.

Для большинства создателей литератур народов Севера в $\mathrm{XX}$ веке мифологические первообразы не были условными, не были отвлеченными сущностями. Они бытовали в сознании и культуре, в обрядах и традициях, в фольклоре и эпосе. Поэты и прозаики активизировали способность первичных идей и образов создавать смыслы, символизировать и пересоздавать данную им в природе реальность в так называемую «вторую реальность». Как форма синкретичного мышления ненцев, а также ханты и чукчей, других народов Севера первообраз наполнялся в литературе новым содержанием. У писателей-северян он был порой своеобычной формой мифологического мышления самих творцов. Как и пространственно-временной континуум, первообразы возникали, развивались чаще всего бессознательно, трансформировались из настоящего, конкретной действительности. О стадиальном развитии первобытного мышления, о двух стадиях - тотемистической и космической - писали в начале XX века академик Н. Я. Марр ${ }^{2}$ и французский философ и этнолог Л. Леви-Брюль ${ }^{3}$. 
Как уже было отмечено, поэты и прозаики северных народов в своем творчестве постоянно обращались к прошлому своего народа, к реликтам ранней культуры.

Сконцентрированное внимание к первообразам, идеям, которые стали из незримого порождения сознания видимыми образами, образцами поведения, - путь не только к открытию новых смыслов в художественных текстах, но и к постижению мировидения героев, к прояснению поступков и поведения их. Вычленение архетипов из имеющихся в произведениях символов, мотивов, мифологем позволяет раскрыть не только фольклорномифологическую основу, но и историко-культурный контекст, индивидуальное своеобразие творцов.

В литературе ненцев «коренные понятия человечества» как составляющая мифов, мифов-сказок актуализированы на уровне сюжетно-композиционных сближений, явных или скрытых цитат, реминисценций, аллюзий, сознательных вариаций и других форм влияния.

Мифологизированное мышление северных народов хотя и было коллективно-бессознательным, но, судя по фольклору и литературе, обладало логической гибкостью и метафорическим богатством. Только обобщения, классификация и анализ могли породить такие своеобразные знаковые системы родства, связи с природой. Бинарные оппозиции в классификациях и обобщениях северян - свидетельство богатства логических возможностей их сознания, метафорических трансформаций.

Постигая с помощью расшифровки (скорее - разгадывания) символики первообразов северян, мы погружаемся в особый мировоззренческий мир, наполненный специфическими символами, жизнеутверждающими образами. Общие для всех культур оппозиции: свет и тьма, добро и зло, радость и горе, поддержка и равнодушие, красота и уродство и другие пронизывают их восприятие космоса, земных стихий, в то же время наполнены специфическими для бытия северян особенностями.

\section{Первичные образы и их перевоплощение в литературах народов Севера}

Суровая северная природа для северян - мир «тревог и битв», где постоянно разворачивается борьба за выживание, порождала свои специфические символы. Так, ветер как необузданная, косми- 
ческая стихия, зачастую подвергающая северян безжалостным испытаниям, издревле порождал в душах тревожные картины, драматические образы, запечатленные в фольклоре и литературе.

Искусно воплощая, вписывая в ткань мифологему ветра в стихотворении «Кладбище тайн», ненецкий поэт Л. Лапцуй представляет читателю полные ужаса картины гибели зверобоев из-за сильных ветров в Карском море. Зверобой призывал на помощь Ямала божество, «но, наверное, буран заглушал его слова». Ненецкие поэты и писатели немало представили разнообразных сцен борьбы со стихией ветра. Они проникнуты практическими советами, как выжить в метель и стужу, как спасти себя путнику, которого застала пурга.

Ветер в восприятии поэтов - одушевленная сущность, как и вся окружающая природа в разные времена года, и сами времена года. В стихах ненца А. Пичкова ветер многолик, несёт как зло, так и добро. Вот перед читателем суровый, своенравный, грозный ветер: «Стреляет осень из тугого лука - / Летит стрела, и завывает вьюга», «Вьет свои веревки-петли вьюга», «и летит с ветрами низко небо / чтоб дождем обрушиться к утру», «Аркан набросив на туманы, / Тянул их ветер своенравный», «Ветер нож свой об осоку точит». «А ветер ворсом серебристым, / Я рад добыче, сердцу горячо / Ведь мой песец, обшитый синим бисером, / Красиво ляжет на твое плечо»; «Ветер жаркой щекою ловлю». Так воспринимает ветер разгоряченный чувствами лирический герой стихотворения А. Пичкова «Этот солнечный день я люблю...», который видит на небе «ветров голубых карусель».

$\mathrm{He}$ бояться буйного ветра, морского шторма призывает А. Пичков в стихотворении «Пусть будет так...» В борьбе со стихией ветра человек закаляется: «И ветру не под силу / Согнуть меня / И испугать меня. / Ветра еще ни разу / Не гасили / В моей душе зажженного огня» («Ветра, ветра»).

В стихотворении «Над землею» Л. Лапцуя ветер предстает хозяином, который устанавливает порядки на земле.

\footnotetext{
Над тундрою северный ветер громады

Кочующих туч подгоняет, как стадо,

Сбивает их кучами, бешено воя,

И осень ведет на узде за собою...

Из поймы озер и болот неустанно

Ветра поднимают в полет караваны

Крикливых гусей, говоря, мол, пора вам

На юг собираться...
} 
Зовут оленеводы ветер летом, когда он спасает оленьи стада и людей от мириад беспощадных комаров. Когда «ветер опустит крыла», то обращаются к нему со словами:

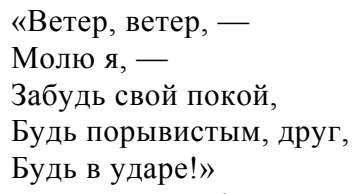

(Л. Лапиуй. «Летом в тундре»)

О тесных и многообразных по своему характеру отношениях ненцев с ветром, узнаем мы из стихотворения Л. Лапцуя «Ветерволшебник», которое начинается со слов: «Не ты ли, ветер, привык от века / Во все людские дела мешаться? / И потому величают люди / Тебя учителем и судьею». Ветер наказывает грозовыми тучами и бездорожьем неразумных, злых людей. В шуме ветра можно услышать пророчество, потому и обращается лирический герой к ветру с просьбой проторить, очистить дорогу в его будущее:

Послушай, ветер, волшебник-ветер,

В грядущий день приоткрой завесу

И, чуть вперед забежав проворно,

Смети весь мусор с моей дороги.

Образ ветра из мифологической реальности перекочевал в литературу, вызывая трансперсональные переживания, открывая новые терапевтические возможности прамыслей и праобразов.

В литературе ненцев находим множество примеров, подтверждающих наблюдение, что в мифологическом сознании ненцев архетип ветра связывался с одушевленным существом космического происхождения, которое способно оказать как позитивное, так и негативное воздействие на человека. Ветер в поэме Лапцуя «Тёр» держит связь с другими планетами, взлетая, например, до луны, возносит героя до небес. Отношение ветра к герою зависит не от поступков героя, а от настроения ветра. То он «пляшет танец свой, ворча как пес сердитый», то «ласковым порывом смахнул с холодного лица снегов седую гриву». Порой ветер выступает в роли друга и советчика: будит героя поэмы «Тёр», когда тому грозит беда: «Чего разоспался на судне плохом? Не видишь - подтаяла льдина», «торит дорогу», подбадривает добрыми словами, когда герой задерживается по пути в родную тундру, где не был много лет. Предсказывает Тёру его будущее: 
«Возвеличен многоусто будешь ты вовек». Ветер откликается «голосом трубным» на звуки бубна, танцует, гладит. Ветер выступает в роли одного из помощников главного героя, боровшегося за то, чтобы принести тундре счастье, тепло и свет. «Вот примчался ветер и рывком / Поднял край плетенки языком, / Раскачавши, сдунул с языка, / И взлетел ковер под облака». Именно ветер после длительной борьбы Тёра с врагами, разорвав трехслойные пласты облаков, освободил солнечные лучи.

Имплицитно главный герой поэмы отождествляет себя с родом, а порой и со всем этносом, свои желания он соотносит с их интересами и эмоциями. Это позволяет ему получить от них поддержку, одержать победу, разрешить конфликт. Эксплицитно Тёр действует на космическом фоне. Его окружают земные и небесные стихии, соучаствующие в достижении цели, такие как ветер. Образно воплощая многоликую суть ветра как космической стихии, поэт раскрывает возможное негативное влияние, порождающее страх перед монстром, и нивелирует душевную тревогу северян, лишая ветер злой силы.

Могучий ветер - универсальный архетипический образ является воплощением сил проявления разнообразия и богатства жизни, космической и биологической энергии.

Как таинственная стихия, творящая для человека добро и зло, ветер воспринимался северянами одухотворенной мистической сущностью. В литературах этот первообраз воплощен метафорой, наполняющей произведения огромной первозданной поэзией человеческого духа, мужества и надежды.

Рэу — герой произведения чукотского писателя Юрия Рытхэу «Когда киты уходят», - оборотень, превратившийся в человека кит, в открытом море громко и протяжно кричит, веря в то, что ветер исполнит его желание:

\footnotetext{
Ветер, сильный ветер,

Смешанный с пылью морской воды!

Подними на могучую спину свою

Кожаную ладью и вознеси

На тропы морских родичей моих,

Чтобы свиделся я с ними и

Сказал, что есть великая сила

В природе, что делает кита

Человеком и дает жизнь

Новому, доселе небывалому

В природе...
} 
В современной легенде Рытхэу «Тэрыкы» главный герой, оказавшись на льдине, оторванной от припая ветром, постоянно борется со стихией и выдержав все нападки, как бы получает в дар спасение - ветер меняет свое направление из открытого моря к берегу.

Ждущая охотника любящая жена Тин-Тин, выйдя на берег моря, пытается с ветром передать мужу свои добрые пожелания и слышит в порывах ветра голос унесенного льдиной мужа. «Ветер выл на разные голоса, но в них Тин-Тин различала ответы Гойгоя».

Ветер не только способен исполнить человеческие желания, но может выступить и в роли наставника, следящего за исполнением людьми древних традиций и обрядов. Почувствовавший большую силу, отказывающийся выполнять обряды охотник («Когда киты уходят»), загарпунил лахтака, вытащил его на берег, снял с него шкуру вместе со слоем жира, а потом «со злорадным громким смехом» бросил его в воду со словами «Ну, теперь плыви и расскажи своим морским богам о том, как силен и велик Армагыргин». В наказание за его слова и дела сильный ветер, призвав на помощь воду, беспощадно расправился с ярангами и байдарами охотников.

Буйство ветра, привлекшего и водную стихию, - жестокий урок для тех, кто забыл традиционные установки мирного сосуществования человека и природы, согласно которым зверя можно добывать себе для пропитания, но при этом испытывать чувство вины и просить прощения. Так автор позиционирует свое отношение к взаимодействию человека со стихиями и животным миром.

Образ ветра, проявляющегося в своей отрицательной и положительной сути, характерен как для ненецкой и чукотской, так и для хантыйской литературы. «Месяцем ветров» называют ханты весенний месяц март, мотивы влияния на человека этой суровой стихии пронизывают произведения Е. Айпина, Р. Ругина.

Для ненецких, хантыйских, чукотских авторов и героев, в том числе лирических, Вселенная одухотворена, тесно связана с их жизнью, смоделирована согласно версиям «культурной памяти», особенностям индивидуального пересоздания действительности.

Мифология мироздания у ненцев, так же как и у ханты, чукчей, ассоциируется с представлениями о трех мирах - верхнем, среднем и нижнем. Небесные светила и земные стихии тесно связывают все три мира и влияют на человека, в каком бы из миров он, благодаря сверхъестественным силам, ни оказывался. 
Как появились первообразы небесных светил и земных стихий в сознании? Как отразились они в мифах?

Космическое мировоззрение человечества, по мнению академика Н. Я. Марра, получило свое развитие еще во время существования «ручного языка» ${ }^{4}$. Он выделял две стадии развития «ручного языка»: первая - стадия звериного тотема, когда появилась и развивалась животно-растительно-тотемная кинетическая речь; вторая - стадия космически-астрально-тотемная кинетическая речь.

Если опереться на данный подход к развитию языка и мышления, можно сказать о стадиальности развития и архетипов, как первичных образов. Смена техники мышления повлекла за собой перенос мифологем из первой стадии во вторую, перенос названий, представлений о бытовании из животно-растительного мира на космически-астральный. Н. Марр, рассматривая примеры кинетического обозначения небесных светил в разных языках, отметил сопоставление их с животными. Поскольку нет исследований кинетической речи прошлого у северных народов, то можно говорить лишь о периоде звуковой речи. В этот период представления о светилах и стихиях закрепились в космогонических мифах, сохранив и развив сравнения с животными. Так, в мифах ханты созвездие Большой Медведицы называется «ногастый (пеший) зверь».

О двуступенчатости создания мифов и фольклора переходного периода - сказаний, преданий, включающих мифы, о связи очередности их возникновения и развития с представлениями о мире животных и о мире космоса писали собиратели и исследователи чукотского фольклора В. Г. Богораз и Л. В. Беликов. Для первой ступени - тотемистической - характерно отражение мировоззрения древнего охотника, для которого животный мир полярного Севера был источником жизни. Л. В. Беликов, определяя особенности формирования повествовательных жанров в чукотском фольклоре, писал, что бессознательно-художественная фантазия чукотского охотника очеловечивала животных, наделяла их двойной жизнью, двойной сущностью: внешней, реальной, видимой и внутренней, невидимой, уподобленной жизни человека. Именно поэтому в мифах зверь приравнивается к человеку-охотнику, но смертельные поединки всегда и неизменно заканчиваются полной победой человека ${ }^{5}$. Он опирался на суждения В. Г. Богораз-Тана о второй ступени развития мифов космогонии, отражении космического мировоззрения: «Мифы о 
создании мира, несомненно, были отнюдь не древнейшим, а более поздним явлением в мифотворчестве чукчей, возникшим уже тогда, когда северные охотники на оленя и приморские зверобои могли уже как-то абстрагировать свои бессознательно-фантастические представления о мире и задавать себе довольно сложные вопросы, как и кем был создан окружающий их мир» ${ }^{6}$.

В связи с тем, что мифы о небесных светилах создавались позднее, они включили предыдущий художественный опыт и имели большее воздействие на сознание окружающих, на их фантазию. В легендах, сказаниях, героическом эпосе, сказках чукчей, ханты, а также ненцев создано немало поэтических образов, связанных с космогонической темой, с «жизнью светил».

Солнцее в литературах ненцев, ханты и чукчей, как и других народов Севера, вошло как символ добра и надежд, источник жизненных сил для людей и всего окружающего мира из устного народного творчества.

Ненецкая писательница Любовь Ненянг в сюжет рассказа «Таймырская быль» вплетает одну из легенд о солнце. Это помогает вселить надежду на чудо девочке Сатте, раскрыть горькие мысли ее матери, попавшей в тяжелое зависимое положение батрачки после смерти мужа. В легенде храбрый богатырь Сатако семь дней и семь ночей сражается до последних сил с темными и злыми духами и великаном Сюдбю Вэсэем, чтобы освободить спрятанное под землей солнце. Обессилев, богатырь падает на землю и засыпает надолго, а проснувшись, видит долгожданное и выстраданное в сражениях солнце, радужные лучи которого приветствуют его, наполняя тело и душу крепостью. «В теле он чувствовал силу и здоровье, голова была ясной. И солнце, огромное, яркое, обливает землю горячими лучами. Сатако понял, что люди пришли ему на помощь и отвоевали солнце у Сюдбю Вэсэя. Теперь на землю пришло счастье...»

Маленький герой рассказа Ледкова «Нарты жизни» Иванко Паханзеда уходит от горестей и тягот жизненных в светлые мечты о Солнце как живой сущности. Он постоянно вспоминает рассказ бабушки о человеке, который дошел до края Земли и за пологом неба увидел спящее Солнце. Мечта мальчика однажды уже почти становится явью - в полудреме он вскрикивает от радости приближения к краю Земли, его восхищает возможность увидеть, где прячет солнце свое огненное гнездо. Однако громкий голос бабушки возвращает Иванко Паханзеду к реальности. 
Солнечный круговорот переплетен в мифопоэтическом сознании северян с постоянным циклическим зарождением и замиранием природы и жизни. Уход солнца, наступление полярной ночи приносит тревогу за выживание и страх, поскольку ночь и темнота сковывающе действуют на волю и жизнедеятельность людей, пробуждают активность духов зла. И в это время ненцы обращаются к луне как источнику света.

Первообраз луны как ночного светила, способствующего путнику, облегчающего жизнь пастуху-оленеводу, заменяющего солнечный свет в условиях полярной ночи, издревле отождествлялся северянами с обликом защитницы. Луна у Лапцуя - символ женского начала: «И помнилось Тёру будто бы луна / На мужском пиру, как женщина, скромна, / В три косы лучи седые заплела, / Улыбнулась и за облако зашла» (Л. Лапцуй. Поэма «Тёр»).

В стихотворении Лапцуя «При луне» небесное тело наделяется материнской ролью защитницы, которая непрестанно наблюдает за их жизнью.

Как уже отмечалось, темные пятна на луне воспринимались ненцами как силуэты мужчины и собаки, что подтверждают и фольклор, и литература. Следует заметить, что у северных народов существовали разные представления о лунных темных пятнах. Так, согласно мансийским легендам и сказкам - это девочка и мальчик с берестяными ведерками. Они оказались вдали от дома в наказание за то, что нарушили запрет и осмелились показывать на Луну пальцами. Рассерженное этим непочтением светило забрало их к себе. В «Лунной легенде» мансийский поэт Юван Шесталов, глядя на луну, не только видит глазами лирического героя девочку и мальчика на луне, но и слышит, «как вода тихонько плещет / В двух ведерочках берестяных». В другом стихотворении «На Севере луна особая...» поэт раскрывает нуминозное влияние луны на человека в долгую полярную ночь. Она способна вызывать «лунные грезы», нередко рождает чувство грусти и печали, неизбывной тревоги: «И в сердце вечный лунный прилив / Прилив без отлива». Как видим, аналогии с сюжетами древних мифов и легенд о небесных светилах, возникающие в сознании как у ненецких, так и у других северных поэтов, оказывают активное воздействие на создание образов, на развитие художественного вымысла.

У ненцев существовал лунный календарь, где луна наглядно олицетворяла круговорот жизни природы и человека, рождаясь, вырастая, убывая, исчезая и вновь рождаясь. 
Мифологемы солнца и луны в хантыйском фольклоре и литературе - многолики и во многом сходны с символикой в представлениях о них у ненцев. С фазами луны соотносили календари, определяли священные дни весеннего и осеннего солнцестояния. Солнце - символ всемогущества, почитаемо как жизнь. У разных народов олицетворяют они Великую Мать или Великого Отца. В хантыйской мифологии солнце связывается с женщиной, а луна - с мужчиной. В мифе «Происхождение месяца» мужчина искал себе жену, но женившись и узнав, что у женщины жизнь короткая, а у него длинная, уходил и искал новую жену. Так было три раза. Когда же он решил вернуться домой, две первые жены разорвали его на две части, отдав одну из них третьей жене. Она стала солнцем, а он месяцем. Солнце и луну достал из нижнего мира Нуми-Торум - владыка неба, охранитель морали и правопорядка. Ханты в сказках его не всегда называют по имени, а употребляют эпитеты Большой бог, Великий бог, Светлый бог, Золотой свет.

Солнце и луна сопровождают и споспешествуют человеку и в Среднем мире и в Нижнем. Мать Детей в романе Айпина «Божья матерь в кровавых снегах» не раз обращается за поддержкой в сложные, экстремальные моменты к Солнцу, которое называет Матушкой, и к Месяцу-Старику, молится им как богам, чтобы не оставили ее в беде.

Эти небесные светила, по мнению ханты (остяков), судя по содержанию романа, способны поддержать и в Нижнем Мире. Не случайно, прежде чем завернуть умерших в оленьи шкуры, Мать Детей углем рисует на внутренних сторонах шкур слева солнце и полумесяц со словами для каждого: «Вот твое солнце. Вот твоя луна».

Кэу, герой повести Рытхэу «Тэрыкы», во время обряда «вопрошания морских духов богов-охранителей» о судьбе младшего брата встает сначала лицом к востоку. Мысленно он объясняет это действие тем, что там начинается рассвет и «именно на этом краю небосвода Птица-Провозвестница каждое утро проклевывает сначала маленькую дырочку, в которую начинает сочиться утренняя заря, а потом расширяет ее, чтобы Солнце могло выйти из своего убежища и осветить землю». Солнце, по его мнению, потому зимой мало светит, что Птица-Провозвестница слабеет и ей приходится долго трудиться, чтобы «выклевать дыру, достаточную для опухшего, замерзшего, красного зимнего солнца». Для описания обряда и размышлений героя использует Рытхэу 
чукотский космогонический миф о добывании небесных светил не только вороном, но и его маленькой помощницей - маленькой птичкой (пчекалгын), которая долбит небесную твердь, чтобы «заря брызнула».

На мистическом восприятии утренней зари, которая воспринималась ненцами не только как предвестница нового цикла суток - дня и, следовательно, носительницей добра, но и провозвестницей будущего человека, построено стихотворение Прокопия Явтысыя «Ненецкая баллада». Героиня его, отправив на фронт семь своих сыновей, встает до рассвета, ждет появления зари и только по понятным одной ей приметам узнает, что «время для тревоги не приспело». Неустанно трудилась она и ждала «с упрямым постоянством» своих сыновей и после победного салюта, не верила похоронкам, потому что доверяла лишь тому, что «зори не кровавились багрянцем».

Возникшие в столь отдаленное время, первичные представления о небесных светилах активизировали творческую энергию писателей-северян в XX веке. Так, хантыйские мифы и легенды о звездах, появляющихся на небе перед утренней и вечерней зорями, побудили Е. Айпина на создание сначала повести «Звезда Утренней Зари» (1980), а позднее - остропроблемного романа о жизни и судьбе его народа «Ханты, или Звезда Утренней Зари» (написан в 1984, издан в 1990). «Вечная звезда неба и земли», так определяет нуменозную звезду писатель. Звезда Утренней Зари постоянно присутствует и в других произведениях Еремея Айпина. В романе «Божья матерь в кровавых снегах» она стала знаком победы над темными траурными ночами, когда живые, отдавая дань памяти ушедшим от них в мир иной, должны сидеть рядом без сна в течение пяти дней. Появление Звезды Утренней Зари связано с надеждами на перемены, которые принесет новый день.

В повести «Звезда Утренней Зари» главный герой по закону сопричастности сравнивает звезды с людьми: звезды живут на небе, испытывая те же чувства, что и люди, - радости и печали, любовь и ненависть. Подобно людям, звезды рождаются и умирают. Каждая из звезд оставляет на небе свой след. И это наводит героя на раздумья о том, какой же след оставляет каждый человек. Его волнует цикличность жизни, потому с особым волнением он ждет момента, когда «замирает Вселенная - и тихо всплывает из-за горизонта Звезда утренней зари». Этот момент 
умирания ночи и рождения дня кажется герою священным, особым моментом творения. «Уловив этот волшебный миг, поймешь, что ты нужен Земле, Солнцу и Звездам так же, как они нужны тебе. Земля не может, чтобы не оставлял на ней свои следы-тропы человек. Солнце не может, чтобы его лучи не согревали человека. Звезды не могут, чтобы по ним не находил свои пути-дороги человек...Человек есть и Земля, и Солнце, и Звезды».

Легенды и сказки о звездах, солнце и луне рассказал герою отец. «Жизнь светил» становится образцом для формирования его собственных нравственных установок. «Для человека главнее Звезда утренней зари: ведь восходить труднее трудного, а падать за горизонт легче легкого», — к такому выводу приходит Демьян, сравнивая Звезду утренней зари со Звездой вечерней зари. Мистическая сопричастность героя с его любимой волшебной звездой достигает своего апогея, когда он в результате длительных раздумий о ней вдруг почувствовал себя Звездой утренней зари. И это привело его к мысли о том, как важно быть человеком с твердой волей, ответственным за свои дела. Герой как бы получил поддержку в трудный жизненный момент, зарядился энергией на будущие важные жизненные дела, на преодоление сложных препятствий и одоление любых невзгод.

Вода и огонь, некогда пугающие человека своей необъяснимостью, легли в подсознание его как нечто неопознанное. В мифах, фольклоре, литературе они часто принимают таинственные многоплановые значения, превращаясь в символ.

Из воды, согласно ненецким мифам, был извлечен гагарой первый кусочек тверди-земли. Эти мифы стали первым представлением поэтического образа воды. Как символ рождения нового времени воспевают, например, в стихах ненецкие поэты и первые весенние проталины, и ручьи, и полноводные реки, появление которых пробуждает их творческое вдохновение. Звук волны полноводной реки в стихотворении Ледкова «Ивовое море» рождает песню, уносящуюся в небо, которая способна «в тундре, промерзшей по самый полюс», разбудить жизнь - «уголек в золе». Вода и огонь, пребывающие в бинарной оппозиции, соединены жизнетворящей метафорой. Леонид Лапцуй воспринимает волну как живую сущность, имеющую крутой нрав, встреча с ней вызывает непостижимые эмоции: «Как похожа эта встреча / На свидание с любимой: Радость огненной рекою — // Встреча солнца и волны!» 
Огонь для ненцев - живая сущность, которая может засыпать и просыпаться, быть добрым и злым, предсказывать доброе и злое. Все эти бинарные оппозиции представлены в повести Неркаги «Илир». Когда главный герой восьмилетний Илир остался один и чум его собрался разобрать хозяин стойбища, к мальчику ночью тайком пришла старая Варнэ и дала совет взять теплый уголек из костра в чуме и незаметно спрятать его. Этому тлеющему угольку, «сыну костра», женщина нашептала таинственные заклинания. Уходя, она поклонилась костру, а Илир последовал ее совету. В самые трудные моменты отчаяния и невыносимых страданий от холода Илир доставал уголек из мешочка и зажимал в руках, отчего ему становилось теплее и он забывался во сне. Уголек стал для него символом жизни.

Для тундровика и таежника костер - это и тепло, и временный отдых, еда, спасение от непогоды, от угрожающей опасности со стороны диких зверей. Огню, костру посвятили немало «самых искренних строчек и строф» не только ненецкие, но и хантыйские поэты. Роман Ругин в стихотворении «Дым костра» называет костер живым, а пламя его дышащим: «Пламя дышит, меняя цвета». Огонь способен вести разговор, символику которого хорошо знали и понимали ханты, как и другие северные народы. В другом своем стихотворении «Костер» поэт называет огонь «собеседником языкастым», «метателем жарких стрел», спасшим немало жизней, отогревшим души братьев-ханты. К этому «священному» огню поэт приглашает погреться, оттаять душой и побеседовать, подружиться: «Приходите все народы / Греться к нашему огню!» Огонь, костер здесь выступает как символ дружбы, единения народов.

Мифологема огня, костра позаимствована поэтами и писателями как из правил жизни, так и из фольклорного дискурса. Так, ханты огонь обожествляли, персонифицировали, давая имена, называли Пугосанки, Най-анки «Огонь-мать» (най употребляется также в значении «героиня», «владычица»). В космогонических мифах ханты огонь участвует в потопе, фигурирует в них и представление о вечности, неуничтожимости огня.

В хантыйской сказке «Нарты с золотом» огонь выступает как символ золота. В прошлом потерять родовой огонь, приспособления, с помощью которых он добывался, значило обидеть духа огня. Искупление греха сопровождалось определенными жертвами, выкупом огня. В названной сказке, где использованы атрибуты современности, три охотника из-за нерадивости жен оказались в тайге без спичек и, увидев с дерева огонь вдалеке, стали 
по очереди ходить туда и просить огня. Однако старик, владелец огня, не давал его без оплаты, просил рассказать ему семь веселых сказок. Младший охотник сумел сказками развеселить старика, и тот превратился в кучу золота, обогатив охотников. Как видим, сказитель, воспевая огонь, придал особую значимость не только огню, но и веселым сказкам, шуткам.

В хантыйской сказке «Бабушка Сясими и внук Имихилы» подрастающий внук заботится о своей бабушке и начинает самостоятельно ловить рыбу в соре (залитых половодьем низменных местах), а потом отправляется, как и его предки - отец и дед, искать рыболовные места «по великой Оби». И всюду Имихилы препятствовали, устраивали помехи, обманывали и даже били лесные духи менгкы. Набравшись сил, возмужав, он поочередно перехитрил и победил всех трех злых менгков - одноголового, двухголового и трехголового. Окончательно же расправиться с менгками помог огонь: «Имихилы развел большой костер и всех менгков побросал в огонь. А чтобы больше на земле хантов не водилось злых духов - вверх летящие искры вверх не пустил, вниз летящие искры вниз не пустил». Вернувшись после побед домой, Имихилы увидел, что бабушка с трудом поддерживает последние догорающие угли очага. Неожиданно тлеющий уголек вспыхнул, «выстрелил искрой» и около очага появилась молодая девушка в красивом сахе - хантыйской одежде, расшитой прекрасным орнаментом. Герой воспринимает появление девушки не как награду за его подвиги, а как выражение благодарности огня, домашнего очага за заботу, постоянную поддержку, осуществляемую одинокой старушкой в терпеливом ожидании возвращения внука. Отец и дед его, по словам Сясими, не были удачливы в борьбе с менгками, не сумели вернуться. И это подчеркивает заслугу героя в борьбе за устранение зла и продолжение рода.

Сказка раскрывает всемогущество огня, который способен своими искрами породить как добрых и красивых людей, так и злых и коварных менгков. Мистическое явление девушкиневесты для победителя из тлеющего угля имеет мифологический смысл - появилась перспектива порождения и размножения человечества, мыслимого в границах рода Имихилы.

Понятие тени как первообраза существует во многих культурах. В ненецкой литературе зафиксирована сверхъестественная возможность тени и ее относительная самостоятельность. Сюжет рассказа «Цинга» Тыко Вылки развивается с опорой на древнее 
ненецкое поверье о визуализации цинги и способах изгнания этого образа - тени смертельной болезни. Действие происходит на огромном безжизненном острове Новая Земля, который осваивали потомки рода Вылко вместе с другими ненцами и коми, потерявшими надежду на выживание на материке. На этом острове и родился знаменитый ненецкий художник Тыко Вылка, автор рассказов и повести, собиратель и искусный исполнитель легенд, героических песен сюдбабц, сказок. Фольклористы В. Тонков, А. Щербакова записали многое из арсенала сказителя, издали ряд фольклорных сборников.

В рассказе «Цинга» Тыко Вылка представил вариант позитивного влияния древних установок культуры ненцев, которые оказались способными в экстремальной для людей ситуации разбудить воображение и интуицию, побудить к действию. Нуминозность, невидимое влияние, загадочная сила бессознательного активизировали сознание героинь.

Из повести В. Ледкова «Синева в аркане» (1970) мы узнаем о мифологизированном отношении к тени человека и своеобразном виде расправы с нарушителями древнего запрета. Человеческая тень становится объектом расправы - старик Явтысый приготовился «убить» тени двух героев, чтобы защитить стойбище от будущих напастей.

Не без влияния древних поверий и сказок возникло зрительное и слуховое явление тени прошлого в стихотворении мансийского поэта Андрея Тарханова «Видение». В ненастный зимний день «согбенный, печальный, седой» герой, названный автором лишь по фамилии - Отшамов, неожиданно услышал звон бубенцов и увидел в окошке «смеющихся и храпящих» коней. Он распахнул двери, его «ударило снегом», «/ А кони / Вздымались в крутящейся мгле». Герой успел заметить, что в санях сидит его молодая, уже давно ушедшая в небытие жена. Мелькнувшая тень прошлого напомнила, как он «жену молодую сгубил» своим безответственным отношением к семье, подтолкнула к раскаянию, к размышлениям о горестном одиночестве.

История развития человеческого сознания, установления общинного порядка, человеческой культуры тесно связана с запретами, в том числе с табу на убийство. И на утверждение этого запрета повлиял первообраз человеческой крови. В мифологическом сознании ненцев отношение к насилию над человеком и лишение его жизни менялось постепенно. В прошлом существовало жертвоприношение человека сядэю (дьяволу), о чем пишет 
в своей работе А. А. Борисов: «Самоеды упорно убеждены, что если принести сядэю (дьяволу) человеческую голову, то непременно сядэй пошлет богатый промысел. И чтобы достать хороший промысел, самоеды стараются задобрить сядэя. Это не сказка, - быль доисторических времен!.. Факт существования у самоедов человеческих жертвоприношений не подлежит никакому сомнению. Мне неоднократно приходилось об этом слышать...» ${ }^{7}$. Подтверждением этим записям служат эпические произведения. Рассматривая эту проблему в своей диссертационной работе «Эпические песни ненцев», 3. Н. Куприянова анализирует сюдбабц и ярабц, в которых описаны факты человеческих жертвоприношений, правда «в форме замышляемой жесткой расправы над угнетаемым сиротой-юношей». По ее мнению, человеческие жертвоприношения не были распространенным явлением и постепенно изживались из обихода, поскольку жертвы обычно спасались во время жертвоприношения (им давали родственники советы, как спастись, и помогали избежать смерти). Совершали человеческое жертвоприношение не положительные герои, достойные уважения, а жестокие и злые люди.

Постепенно в сознании ненцев утвердилось понимание греховности человекоубийства: совершившего это преступление стали считать «порченым» человеком, у которого «дурная кровь». Он способен повторить содеянное, и встречи с ним предпочитали избегать.

Идея наказания человека с «дурной кровью», совершившего убийство, легла в основу романа-дилогии В. Ледкова «Месяц Малой Темноты» и «Люди Большой Медведицы» (1970) и повести Анны Неркаги «Илир» (1979). Если идея наказания за преступление-убийство в повести А. Неркаги «Илир» прочитывается только благодаря разворачивающимся событиям и завуалирована, то в романе-дилогии В. Ледкова «Месяц Малой Темноты» и «Люди Большой Медведицы» она постоянно выделяется автором, герой, совершивший убийство, откровенно подвергается остракизму окружающими и страдает от этого. Запрет, как уже было отмечено ранее, стал сюжетообразующим, поскольку именно нарушение табу положено в основу конфликта между героем и его окружением.

С описания запретов, этической маркированности поведения в родоплеменном обществе ненцев начинает писатель свою вторую часть дилогии: «Много разных законов придумали люди тундры. Поднял руку на отца с матерью - считай, что остался 
без руки: она засохнет, переломится и отпадет. Украл - на родовом суде тебе отрежут палец. Подстрелил без надобности зверя, поймал ненужную тебе птицу, погубил забавы ради что-то живое - тебя осудят люди, ибо запятнал ты свое имя - Человек. Но самым тяжким грехом на земле было убийство...». «“Ненец, береги человека! Помогай ему!” Не так уж много людей на нашей тундровой земле... И если ты погасил жизнь одного из них - забудь, что имя твое Человек. Друзья отвернутся от тебя, забудут дорогу к твоему чуму, и ты останешься в одиночестве. Тебе никто не подаст руки, для тебя не проснется в чуме соседа ни один уголек... Люди будут бояться тебя - ведь по преданию в жилах убийцы течет дурная кровь, которая может опять заставить его нарушить закон предков».

Главный герой повести Анны Неркаги «Илир» - оленевод Майма - пролил человеческую кровь, бросив нож в спину своего бывшего пастуха, разгадавшего тайну о спрятанных оленях. Он спокойно воспринял жертву своего отца, который взял вину на себя. Отец воспользовался суетой и подложил в ножны сына свой нож. Эта жертва сопровождалась мыслями героя о том, что старик должен отдать стойбище в надежные молодые руки. Он не боролся за свою жизнь, потому что в нем, вероятно, ожила прежняя традиция ненцев, когда старики ради выживания и благополучия детей добровольно давали согласие на то, чтобы их убивали, чаще всего душили.

Совершив убийство, Майма превратился для всех окружающих в настоящего неукротимого зверя, забывшего о добре и жалости. Он творит зло безнаказанно, не задумываясь о реакции людей. Главное - приумножить стадо. То, что жизнь в стойбище постепенно умирает, не беспокоит Майму, единожды убившего человека. Это убийство стало проклятьем для его жизни и привело к смерти. Не выдержав мучений, мальчик-сирота Илир, которого Майма превратил в настоящую собаку (он разучился говорить, поскольку Майма запретил ему разговаривать, выполнял обязанности забитого Маймой до полусмерти и умершего от ран пса, бил мальчика и превратил его лицо в нечеловеческую маску), направил стадо от обрыва на своего хозяина. Олени, изза которых Майма нарушил человеческие запреты, затоптали звероподобного человека. Эта смерть, по мнению автора, логична - освобождение Земли от зла, а души мальчика от нелюбви к жизни. Илир как бы возродился - он впервые после многих дней сумел крикнуть и произнести жизнеутверждающие и объяс- 
няющие поступок слова: «Мама! Голубые великаны! Грехами живущий! Я больше не собака! Я отплатил за всех!»

Первообраз «крови», в том числе «человеческой крови», многозначен и энергоемок в литературе северян. Долганская поэтесса Огдо Аксенова в стихотворении «Обычай предков», посвященном отцу Егору Дмитриевичу Аксенову, противопоставляя мир и войну, любовь и ненависть, опирается на древнюю традицию долган - не проливать человеческую кровь. Используя прием эксплицитной реминисценции, словами своей бабушки, услышанными в детстве, поэтесса воскрешает былое назиданиезапрет: «Если капнешь ты кровью на землю - беда. / Ты нарушишь священный обычай. / Кровь людская по ней не лилась никогда. / Мы знакомы лишь с кровью добычи».

Остяки (ханты) также придавали большое значение человеческой крови как фактору священному, животворящему и способному оказать негативное влияние на окружающих.

В романе Еремея Айпина «Богоматерь в кровавых снегах» Мать Детей внимательно отслеживает, чтобы пролитая на снег человеческая кровь была засыпана снегом и даже заложена ветками дерева, чтобы «ненароком не наступил кто-нибудь» на нее. Именно кровь, как и уходящих в иной мир людей, героиня не называет известным для всех словом, а именует даже в мыслях «светлая», «яркая». Разговаривая с убитым сыном, женщина забрасывает окровавленный наст дороги и размышляет: «Человеческую "светлую”, “яркую”, т. е. кровь, не должны видеть ни Солнце, ни Луна, ни Небо, не должны клевать-крошить ее вместе со снегом ни глупые птицы, ни неразумные звери».

Она считает кровь частицей души человека, которая способна воздействовать на окружающих. Поэтому женщина всякий раз пытается очистить огнем пространство между кровью мертвых и живыми.

Негативно влиять способна лишь кровь погибшего, мертвого человека, кровь живых может быть спасительной. Животворящая способность крови одного человека повлиять на другого проявляется в романе в том, что с помощью своей собственной крови Мать Детей спасает гибнущего от голода и холода младенца, единственного оставшегося в живых сына Савву. Унять плач малыша и согреть его она решается с помощью теплой и питательной еды - собственной крови. На это ее в самый безнадежный час подвигла небольшая ранка, из которой она, чтобы остановить 
кровотечение, попробовала теплую и солоноватую на вкус кровь. А главное - она вспомнила сказку про птицу Карс, которая вызвалась отвезти героя сказки в нужное ему место с одним условием - он будет подкармливать ее в полете мясом. И когда мясо кончилось, человек стал отрезать куски от своих ног. Они долетели. Птица Карс, узнав о человеческом поступке, выплюнула два последних куска, которые тут же приросли к ногам человека.

Вспомнив эту сказку, Мать Детей надрезала свою грудь и накормила погибающего малыша. Кровь матери спасла последнего из детей гибнущего рода.

Запрет, будучи существенным регулятором жизнедеятельности общества, был направлен на установление границы, за нарушение которой неотвратимо следовало наказание. В стихотворении «Если ошибся» Л. Лапцуя ярко представлена картина еще одного вида сурового наказания за нарушение табу. Согласно ненецким установкам, оленевод должен беречь хорей ${ }^{8}$ как зеницу ока. Если же сломал хорей - немедленно почини, иначе заметившие сломанный хорей сородичи могут с криками побить. «Не уберег хорей — / Значит, терпеть умей», - советует поэт. Если не выдержал побоев, вырвался и сбежал, то старцы могут подвергнуть более суровому наказанию: «Нет сломавшим хорей / Места среди людей». Хорей - надежный помощник оленевода, им не только управляют ездовыми оленями, но и ставят его у нарты, прочно закрепив в земле или в снегу, острием по направлению ветра, если путник решил отдохнуть и вздремнуть во время пурги. И тогда занесенного снегом найдут проезжающие мимо или те, кто будет искать. Вероятно, значимость хорея для выживания и спасения в сложных тундровых условиях и породила столь суровое наказание за безответственное отношение к нему.

В фольклоре и литературе ненцев актуализированы и художественно представлены запреты, способствующие сохранению окружающей природы.

Леонид Лапцуй, например, активно собирал народные изречения, содержащие запреты, в том числе те, в которых звучат экологические мотивы, поэтизировал их. Так, древний завет гласит — не обижай природу:

\footnotetext{
Если тундре нанесешь

Ты обиду или рану,

Или порчу океану,

Сам в себя ты всадишь нож.
} 
Поэтические воззрения северян на родной край, наблюдения над реальными свойствами природных явлений, нашли отражение в фольклорных первообразах земли, отчасти трансформировались в литературе, однако традиционное представление о земле как матери осталось неизменным.

Как уже отмечалось, архетип Матери-Тундры нуминозно действует на сознательную установку ненецких поэтов, становится объектом поклонения и служения ей, источником премудрости. Устремляются в бескрайние просторы тундры за поддержкой и подпиткой силой, мудростью, как сами поэты, так и их лирические герои в стихотворениях и поэмах Л. Лапцуя, В. Ледкова, П. Явтысыя, И. Юганпелика.

Образ матери, рождающей людей и все силы природы, - самый древний мифологический образ. Великая Праматерь стала культом, которому поклонялись, поскольку процесс рождения жизни был перенесен от рождения человека и природы на Вселенную. Мать-земля ассоциировалась в сознании человека с прочностью и надежностью, с той хтонической мощью, которую она передает своим потомкам.

Безобразное и злое ассоциируется в сознании поэтов с зимней непогодой и коварством людей, а также с реакцией МатериТундры на нарушение завета беречь природу. Так, в пору жестокой пурги, когда прячется человек в чуме или снежной норе («куропачьем доме»), шаги тундры кажутся ему «яростными». «Хлесткими» шагами ступает она в ответ на «лязгнувший капкан или беспощадный выстрел браконьера». Браконьерство издревле - табу для ненцев, строго исполнявших завет предков-охотников - не стрелять птиц во время выведения птенцов, не убивать зверей и птиц больше, чем необходимо для выживания.

Л. Лапцуй называет мистическую Женщину-Тундру «Ямала доброй душой». Размышляя о легендарной Женщине Ямала, о ее особой сверхъестественной силе, поддерживающей ненцев в экстремальных ситуациях, о чем не раз слышал он от охотников и пастухов, поэт пытается увидеть и услышать «черты ее мудрые, косы в пороше серебряной», чтобы «разгадать ее сердца поэзию».

Но люди советуют: «Брось неразумные помыслы!

Увидеть тебе не дано эту дивную женщину.

Но всюду она за тобою идет невидимкою,

Нигде не минуешь ты взгляда ее ястребиного. 
А если захочешь ты с ней по душам

побеседовать, -

Ты слух напряги, чтобы стал он острее

оленьего,

Ты ум напряги, чтоб исполнился доброю

мудростью,

И слушай, и думай, и звуки природы

разгадывай.

И вот упоенный ветров громозвучною музыкой,

Почувствуешь ты этой женщины чудной

дыхание».

В окружающей природе, в журчании воды советует автор попытаться увидеть и услышать Женщину-Тундру. Для этого надо быть более зорким и внимательным, уметь не только смотреть, но и видеть, не только слушать, но и слышать.

Сияние Полярной звезды, которая «всенощно бодрствует над тундрой, как при стаде бодрствует пастух» (ненцы называют ее «матерью всех звезд»), автор соотносит с сиянием глаз фантастической Женщины Ямала. И считает, что не напрасно охотники и оленеводы, отправляясь в путь, не забывали «на сугроб подталый» отсыпать табачку для своей покровительницы.

Яркая неподвижная точка в центре Северного звездного полушария в созвездии Малой Медведицы символизировала у ненцев постоянство, была почитаема как высшая точка мистической оси, связывающей естественные и сверхъестественные силы, оказывала, по их мнению, поддержку человеку.

Поэт наделяет мистическую Женщину космической властью, утверждая, что этот мир ей тоже подвластен.

В поэме «Женщина Ямала» Лапцуя появление лунного света, путеводной звезды в темную ночь связано с ее помощью, которую она оказывает отчаявшемуся путнику:

Ты зовешь, зовешь ее на помощь.

В час, когда подмоги нет иной.

И невесть с чего слепая полночь

Прозревает доброю луной.

И пурга как будто приустала,

Ярче путеводный луч звезды...

Может, это Женщина Ямала

Вызволяет сына из беды?

В его стихотворении «Волна» лирический герой ведет диалог с девушкой-волной, которая влечет его с детства, манит за со- 
бой, но он колеблется: то устремляется душою за своей любовью, то возвращается, потому что сильнее для него оказывается зов тундры «с материнскою тоской».

Нужно подчеркнуть, что образ матери в ненецкой поэзии обобщен не столько в реально-жизненном аспекте, сколько спроецирован на первообраз, придающий определенный мифологический фон и наделенный авторитетом, некой нуменозностью - ослепляющим влечением.

Хтонический тип матери и образ реальной земной матери имеют явно выраженный символический характер, идеализируют ее. Идеализация есть, по мнению Юнга, скрытый амулет ${ }^{9}$. Идеализируют там, где нужно изгнать страх. Бессознательное и магическое влияние на возникновение страха оказывают, например, появляющиеся угрозы потери истока жизненных сил, полученных от матери еще при рождении.

Идеализация матери свойственна большинству ненецких поэтов и Л. Лапцую, и В. Ледкову, и П. Явтысыю, и Юганпелику. Постоянно возрождая в памяти хтонический тип матери, Л. Лапцуй приписывает ей космическую силу, умение общаться со звездами. В стихотворении «Где ты рожден?» он пишет о своей вере в то, что «Звезда в ночи прозрачна и тиха. /Звезде, наверно, мама так велела, / Следила зорким глазом пастуха, / Где я ходил и что я в жизни делал». Поэт наделяет мать способностью понимать язык окружающей природы: именно молитвы матери о спасении детей, обращенные к воде, помогли, по его мнению, спастись от наводнения в Обской губе, когда вся семья оказалась на острове («На островке»).

Мать для поэта - нечто, имеющее явно выраженный знаковый характер. Она для него источник света и счастья, поскольку когда-то разделила между всеми подросшими детьми перед их уходом из чума свой заветный уголек, который «в сердце тлел, забившись в самый темный уголок». Этот материнский дар стал «заветным ключом от счастья», светил им, помогал идти по жизни («Ключ»).

Мать - молчаливая праоснова возвращений к родному очагу и поддержка в поисках пристанища на чужбине, т. е. основа всяческого начала и конца. Мать - это самоотреченная всепобеждающая любовь, это личное переживание, глубокая тайна чувств.

«О маме думы в час, когда они - порой, прозренью мудрому сродни» (П. Явтысый). «Благодать сердечного тепла» каждой женщины заложена, по мнению П. Явтысыя, вместе с лаской ма- 
теринских глаз при рождении, поэтому он утверждал истину «Женщина - владычица тепла».

Размышления о матери, о великодушной Женщине Ямала, о современницах наполнены пиететом к ним, гиперболизированным некрасовским восхищением. Лапцуй склоняет перед женщиной голову и высказывает предположение, что в будущем «в белом полярном просторе сложат прижизненный памятник сильной и мудрой Женщине... чтоб высился вечно над тундрой».

Образ женщины-матери явился и для хантыйского прозаика Еремея Айпина действенной, активизирующей силой, способствовавшей созданию глубоких по мысли, национально-специфических произведений, в том числе романа с говорящим названием «Божья Матерь в кровавых снегах».

Образ главной героини романа наполнен искренним то тревожным, то радостным восхищением. Действительно, Мать Детей проявляет чудеса выдержки, находчивости, доброты, силы. Это и заботливая мать, и мудрая наставница, и трудолюбивая, умелая хозяйка. Терпеливо, не теряя надежды на спасение детей, женщина продвигается к родному стойбищу. Она не позволяет себе расслабиться ни при каких обстоятельствах, даже при самых экстремальных: она теряет одного за другим членов своей семьи: мужа и четырех детей. Силы ее на исходе, и тогда Мать детей обращается за поддержкой к Матери-земле.

«Сидящая Матерь», «Земля-Матушка», «Богиня Земля», «Всесильная Богиня», просто «Сидящая» - так называет в своих размышлениях отчаявшаяся женщина, обращаясь за поддержкой с нижней стороны, к родной земле. Она беседует с ней и постоянно прислушивается к звукам и мыслям в ожидании ответа на вопрос «Как быть?» В результате «то ли в дреме, то ли наяву», получает ответ:

«-Живым быть».

Немногословный, многообещающий ответ придал женщине силы, она собрала всю энергию в локти и колени и поползла, превозмогая боль, в сторону людского жилья. Таково метафизическое разрешение проблемы автором.

Мать Детей обращается за поддержкой не только к МатериТундре, но и к символу христианской веры - Богородице. И та приходит на выручку в кажущиеся безвыходными моменты, помогает преодолеть препятствия, а порой просто обрести крепость духа, гармонию между умом и чувством. Богородица в романе Айпина — жизнеутверждающий образ человеческой доб- 
роты. Она выступает в роли примиряющей сущности, которая способна воздействовать на поведение людей, помочь, направить в экстремальной ситуации.

Морально-этическое и художественно-эмоциональное содержание образа отца в фольклоре и литературе народов Севера отлично от образа матери, несет другие социальные и космогонические функции, в целом имеет больше конкретно-жизненных воплощений. У ненцев оно связано с фигурой, от которой исходят решительные наставления, запреты, советы, выражается готовность подчиняться этим установлениям и ценностям, зачастую связывается как с хтоническим типом, так и с земным, реальным родителем.

Если ты попал, дружище, в заметь ${ }^{10}$,
Если смерть перед твоим лицом
Лязгает звериными зубами,-
В мыслях ты беседуешь с отцом.
Все его уроки, все советы
Начинаешь молча вспоминать,

(Л. Лапџуй. Поэма «Женщзина Ямала»)

Подплывая в «лодке памяти» к своему отцу Андрею Михайловичу, погибшему в годы войны, П. Явтысый с благодарностью восстанавливает заповеди отца, который научил его всему тому, что стало в жизни «опорой верной».

В детских мечтах мальчика всегда было желание «взрослым стать, чтоб научиться, как отец, скорее: стрелять песцов и в цель тынзей метать, упряжку-ветер подгонять хореем...».

Вспоминая предков, живших на острове, где он родился, В. Ледков, видит отца, который здесь охотился. И «завещал он мне нож свой острый / Да ружье, да еще сполна / Ту любовь, что согрела остров, /мокрый, как тюленья спина» («Дремлет остров...»).

Детскими воспоминаниями о наставлениях отца наполнено стихотворение Л. Лапцуя «Первые шаги». Реальный отец поэта приучал его рано вставать, не хныкать, брал с собой на охоту, чтобы знал, как выслеживать песца, понимать крик птиц, находить путь домой во время пурги. Он хотел, чтобы мальчик «в свои семь лет умел любой разгадывать секрет, стал пастухом, охотником примерным». Эта учеба не пропала даром: он стал упрямым, умелым охотником и оленеводом. Следовал советам отца быть наблюдательным, сдержанным и настойчивым, не бояться трудностей. 
Мужественности и профессиональному умению поэт учился не только у отца, но и у деда. В стихотворении «По заветам деда» свое умение выживать в сложных условиях тундры поэт приписывает обкатанному трудностями и неустанным трудом оленевода деду, который передавал ему свои секреты:

Не утону я в сугробах тундры,

Обвалов снежных не испугаюсь.

Я все осилю - и дождь, и вьюгу,

Затем, что помню заветы деда.

Созданные Лапцуем образы отца и деда являются не только влиянием реальных родственников, в них нашли отражение установки и ценности древности, представления идеальных первопредков.

Своеобразная мечта об отце - герое отражена в стихотворении Л. Лапцуя «Прошло мимо». Его реальный отец был больным человеком и рано ушел в мир иной, но поскольку это было во время Великой Отечественной войны, то поэт пишет о нем как о фронтовике.

Идеализация образа отца отражена и в автобиографии поэта, написанной за несколько дней до смерти. В ней он делился воспоминаниями о том, как кочевал с ним по тундре: «Отец часто усаживал меня на свою нарту рядом с собой, так мы с ним часто ездили ставить капканы на песцов. Учил этому ремеслу и меня. Обучал также оленеводческому делу - пасти оленей...» В детстве приобщившись к секретам многотрудного дела, Л. Лапцуй всю жизнь гордился своими умениями, вспоминал с благодарность заветы отца. В памяти встает человек со светлым умом, с талантом воспитателя, постоянно напоминавшего: «Упряжь своей нарты содержи в порядке. Когда вырастешь, люди будут ценить и уважать за эту привычку, за неряшливость тебя будут осуждать. Даже если ты не будешь пастухом, помни: нарта тундры - это нарта жизни, каково отношение человека к рабочей нарте, таков и человек».

Описание отца в автобиографии постоянно перекликается с художественным образом в его поэзии. В стихотворении «Воспоминание» предстает отец как умелый воспитатель, передающий свой опыт тундровика, умеющего находить дорогу домой, когда «пурга поднимет вой и мгла небес с землей соединится».

Отец мне говорил под шум пурги:

«Сын, никогда от тягот не беги, 
В железной схватке со стихией снежной

Ты станешь острым, словно нож железный».

И не раз отцовские заветы помогали Л. Лапцую в сложных жизненных ситуациях:

Я был упрям, не поддавался бедам

Да и теперь не страшен мне буран,

Я не собьюсь - иду отцовским следом...

Жизнь и подвиги предшествующих поколений стали ориентирами и поддержкой для Млеткина, героя романа Рытхэу «Последний шаман». Автор создает индивидуальный миф личностей своего рода, используя самобытную образную систему. Она переводится в абстрактно-логический план, для того чтобы выразить и развернуть идеальную сущность представителей рода. Первообразы становятся для последующих поколений идеалом. Оппозиция священного - профанного, заложенная в первообразах, отражает ценностные ориентации потомков.

И в эпосе и в литературе ненцев, чукчей и хантов нашел отражение парадокс первоначальных воззрений о ребенке - выделение его детской слабости и сверхчеловеческих возможностей. С одной стороны, перед нами бессильный ребенок, который попал в лапы жестких обстоятельств или могущественных врагов, ему грозит опасность уничтожения, с другой - маленький человек, обладающий силами, которые далеко превосходят человеческую меру. В ненецких сказках часто встречается сюжет о спасении женщиной мальчика - продолжателя рода. В разгар боя она обычно прячет малолетнего наследника в ямку, образовавшуюся на снегу под железным листом, на котором разводится огонь в чуме, приговаривая: «Тебе надо выжить, видишь, злой враг всех твоих сородичей погубил. Тебе надо быть продолжателем рода и ради тебя женщинам разжигать родовой огонь». Улучив момент во время сражения, спасительница уносит малыша и скрывается с ним в заброшенном логове зверя или в опустевшем чуме до тех пор, пока он не вырастет.

Героем-ребенком стал Тёр в одноименной поэме-сказке Л. Лапцуя. Здесь мальчик - символ сохранения рода. Он должен возродить уничтоженное врагами племя. Отец мальчика, понимая, что пощады от коварно напавших на стойбище Ваев не будет никому, крикнул сестре:

...Младенца укрой!

Стань сиротинке наставницей мудрой, 
Должен он выжить, последний в роду -

Пусть наш семейный костер не погаснет!

Спрятав мальчика под ягушку (меховую одежду), женщина скрылась в чаще, поселилась с ним в волчьем логове, вырастила продолжателя рода. Стать же защитником, достойным памяти отца, отомстить за его гибель, Тёр смог лишь подготовив свое тело и душу к новому периоду своей жизни, пройдя жестокие испытания, преграды инициации.

Возвращение в мир детства в стихотворении В. Ледкова «А я и не знал...» связано с мечтами, рожденными бабушкиными сказками. Мальчик мечтал то дотянуться рукой до звезд, низко висящих над чумом, то долететь до горизонта, то «спящего солнца гнездо золотое украдкой за краем небес подсмотреть». Реальное же военное детство В. Ледкова было «озябшим», пронизанным тоской и ощущением небывалого одиночества, поскольку сопряжено было с гибелью матери, которая своей смертью оставила его «одного среди белых снегов» («Я вышел из чума»). В тот час «взглянула луна на сонный покой окровавленным оком».

Озноб и голод военного детства предстает и в стихах Леонида Лапцуя, который в эти страшные для всех годы стал кормильцем семьи, заменил умершего отца. В стихотворении «Прошло мимо» он объясняет свое старшинство в семье не простой смертью отца, а его героизацией, фантазией о том, что якобы отец «ушел недавно на войну», с гордостью называет себя «старшим сыном фронтовика». Свои реальные тяготы нелегкого труда наравне со взрослыми поэт выразительно представил в стихотворении «Память», где десятилетний мальчишка тяжелой пешней долбит двухметровый лед, чтобы опустить сети, и действо это кажется ему бесконечным, а лед и снег железным. Пробуждали страх мальчика моменты, когда «Вываливалась лопата / Порою из чьих-то рук, / А кто-то не смог проснуться, / Обледенев к утру».

Личный детский опыт послужил Лапцую для описания воспоминаний лирического героя в стихотворении «Прошло мимо».

Действие происходит в чуме. Ранним утром мальчик, сонный, угрюмый, обветренными руками трет глаза, чтобы заставить себя встать. Озноб пробирает его, когда он представляет на своем теле поданную матерью не успевшую просохнуть старенькую одежду. Мальчику льстит, что завтракать мать и младшие братья не начинают без него, кормильца, заменившего отца, ушедшего 
на фронт. Он трудится наравне со взрослыми - то гребет, то тянет сети, не жалуется:

Терплю, продрогший до костей.

Ладони ноют болью острой,

Натертые до пузырей.

Сны мальчика наполнены волнениями, переживаниями во время изнуряющей недетской работы.

Жесткие, суровые условия жизни детей-северян делали их достойными восхищения, маленькими героями. В повести Анны Неркаги «Илир» - жизнь и судьба мальчика-сироты. Восьмилетний Илир проходит все круги ада, «хаоса», испытывает состояние, близкое к смерти, почти превратившись по воле хозяина в собаку, и возрождается к новой жизни: обретает речь, силу, желание жить и отстаивать свое право на жизнь, побеждает в неравной схватке с жестоким, потерявшим человеческий облик хозяином.

«Мотивы героического детства частично также отражают обряды инициации, а частично служат общим выражением, знаком героизма», - писал Е. М. Мелетинский, рассматривая обрядовый фольклор ${ }^{11}$. Инициация воспринималась как переход возрастной границы, на которой разворачиваются сакральные события. В литературах народов Севера мифологема инициации обычно трактуется как момент духовного взросления героя, преодоления сложных препятствий. «Юнец, птенец невозмужалый» Тёр, главный герой поэмы Лапцуя, отправился искать и освобождать из неволи солнце, чтобы победить тьму и холод, отомстить за отца, преодолев страх перед неизвестностью, перед теми трудностями, о которых предупредила его вырастившая женщина. Темнота и холод предстают часто в мифах и сказках ненцев не временными, а вечными, вызывают страх. Страх же - самое древнее и самое сильное чувство из всех, что способны испытывать живые существа. Он заложен в их биологической природе (в виде инстинкта самосохранения) и связан с ограниченностью сил и возможностей; от страха, как ни от какого другого чувства, можно умереть в прямом смысле. Переборов страх, Тёр сделал первый шаг на пути возмужания, устремившись в неизвестность. С детским любопытством и доверчивостью он три раза пытался установить дружбу с Ваями, завоевателями земель его рода, но те, нарушая все правила тундрового гостеприимства, жестоко расправлялись с ним. Три раза Тёр находился на грани гибели. И эти испытания закалили его, сделали хитрее и мудрее. Мифо- 
логический мотив преодоления завершился переходом героя в иное состояние. Возмужав, он стал героем-освободителем.

Инициация как новое рождение человеческого «Я», но уже в ином качестве, отражает бинарные оппозиции архаического сознания: сильный - слабый, бесстрашный - трусливый и др. Во время этого обряда закладывались в сознание коллективные представления в таких эмоционально выразительных образах, которые невозможно забыть, они постоянно всплывают в определенных жизненных ситуациях. Нервное напряжение во время посвящения похоже на пытки и не может обесцветиться. Никакие иные эмоции в последующем неспособны заглушить этот познавательный феномен. «Действие это становится то влиянием, то силой, то таинственной мощью, в зависимости от объекта и обстановки, но само действие неизменно признается реальностью и составляет один из элементов представления о предмете» ${ }^{12}$. Мифы и сказки, героический эпос, а позднее литература усиливали для северян значимость инициации как этоса. Понятие этос концентрирует в себе нравственные начала, которые не проявляются в повседневной жизни. Человек, действия которого диктуются этосом, совершает нечто исключительное, выходящее за рамки обычных представлений и поступков, нечто такое, что не поддается привычному рационалистическому объяснению. Этос проявляет себя в особых исторических ситуациях, когда под угрозой оказываются важнейшие гуманистические принципы бытия человека. Поскольку этос призван напоминать традиции общности, то он проявляется тогда, когда они оказываются либо потерянными, либо подвергающимися реальной зловещей опасности. «И тогда этос, подобно стихийной, невидимой силе повелевает людям не забывать о том, что они являют собой сообщество, что все они связаны друг с другом» ${ }^{13}$.

Описание художественных воплощений первичных представлений в системе коренных воззрений народов Севера имеет как аксиологическое, так и онтологическое значение. Постижение того, как первообразы, возникшие на заре человечества, структурировали понимание окружающей действительности, пробуждали творческую активность, проявлялись в фольклоре и литературах северных народов, делает сакральное имеющим силу, реальным, а взаимосвязь различных эпох ощутимее. 


\section{Логос - первичный вечный образ}

В мифопоэтической картине мира неотъемлемой частью является Логос как первообраз и первоисточник, создающий гармонию мира и активно участвующий в творческом литературном процессе.

Без глубинного постижения «творящей природы слова», Логоса, его роли в переходе сознания от хаоса к космосу, в формировании первообразов и художественного сознания сложно высветить мифопоэтическую картину мира северных литератур, опирающуюся на этномифологизм и фольклор. Остановимся более подробно на этом направлении, обратившись, в первую очередь, к литературе ненцев. Среди мифологических и фольклорных первообразов, нашедших свое отражение в ненецкой литературе, мы выделили - слово-песню, слово-сказку. Вездесущая Песня-Мынико (слово-песня) в поэме Лапцуя «Тёр» появилась раньше других действующих лиц, став для них невидимой героиней. Она наблюдает за развитием событий и порой помогает положительным героям.

О песне той особый сказ.

Над хлопотливой тундрой

Она, бывало, всякий раз

С людьми встречала утро.

Её мотив единым был

Для сотен поколений,

Но каждый ей слова дарил

По своему уменью.

Благословляла мирный труд

Она радушным сердцем,

И песней-Мынико зовут

Её от века ненцы.

Песня-Мынико незримо сопровождает главного героя поэмы, подбадривает его, радуется вместе с ним его победам и в конце жизни исполняет его прощальный завет-наставление ненцам.

Люди ловили ту песнь на лету,

Всё о прошедшем и будущем вызнав,

И поднималась она в высоту,

Словно хорей над упряжкою жизни.

Ясным улыбкам учила она,

Правде, добру и отваге учила. 
Слово-песня, Логос-слово выступает в фольклоре, эпосе и литературе ненцев в качестве некоего самостоятельного герояповествователя. Повествование ведется от третьего лица, «слово» перелетает от одного героя к другому или с одного места действия на другое. Этот прием создает впечатление соответствия во времени, синхронности событий, происходящих с разными действующими лицами.

Для того, чтобы найти подходы и определить этнометодологию, как раскрыть гиперсемиотичность литератур народов Севера, специфику формирования и становления их, представляется актуальным осуществление более целенаправленного изучения процесса формирования художественного сознания и, в первую очередь, постижения тайны, смысла, значимости Логоса как первообраза и первоисточника. Это поможет ярче представить мировоззрение писателей, понять судьбы и характеры их героев, в том числе лирических героев. Логос как главный фактор деятельности ума и смысловой упорядоченности бытия и сознания, противостоит всему безотчетному и бессловесному, бессмысленному и бесформенному в мире и человеке. Термин Логос в древнегреческой философии означает «одновременно "слово" (или "предложение”, “высказывание”, “речь”) и “смысл” (или “понятие”, “суждение", “основание”); при этом “слово” берётся не в чувственно-звуковом, а исключительно в смысловом плане, но и "смысл" понимается как нечто явленное, оформленное и постольку “словесное”» (Большая советская энциклопедия). Введенный Гераклитом, термин Логос соотносился с космосом, воспринимался как закон бытия, гармонии мира, а не просто житейское обозначение человеческого «слова». Космический Логос, по мнению древнегреческого философа, как и подобает слову, «окликает» людей, но они, даже «услышав» его, неспособны его схватить и постичь.

Среди мифологических представлений об окружающем мире «логос» связывают с первыми представлениями человека об организации миропорядка. С помощью логоса, стремясь из движущейся материи вывести некий порядок, человек в прошлом трансформировал ее в космос, с помощью логоса определял всеобщий миропорядок, всеобщую инвариантную меру всех вещей, «мерно» повторяющийся ритм природы. Овладение им можно назвать наполнением универсальных архетипических образов конкретным историко-культурным содержанием. Как считают философы и лингвисты, в широком смысле слова язык значительно 
древнее сознания и вербальной речи. Сознание формировалось из бессознательного с помощью слова, речи. Формированию предшествовал образ слова, способного перенести информацию о чувствах, желаниях. Умение «слышать» не только осознанный текст, но и бессознательный подтекст позволяло значительно расширить и углубить зону взаимного понимания. Русский философ-идеалист Павел Флоренский употреблял термин «логос» как обозначение «цельного» и «органического» знания, характеризующегося равновесием ума и сердца, анализа и интуиции. Он считал речь вибрацией всего организма, всех его физических и духовных энергий. Резонансным воздействием вибраций на человека и даже на неодушевленные предметы Флоренский объяснял магичность слов. По его мнению, носителем сознания (человеческой психики) являются не только мозговые структуры, но все человеческое тело - каждый его орган, каждая клетка. Эмоциональный настрой человеческого мышления зарождается в телесных структурах. Человек мыслит всем телом.

Слово-песня (вада-сюдбабц,ярабц-мынико) - поэтическое явление, особый признак ненецкой поэтики, оно пришло из ненецкого фольклора, мифологических сказок и исторических преданий. Происходит персонификация повествования, обязанности (роль) автора, рассказчика исполняет слово-песня, речь-слово. От его имени ведется повествование, которое переходит от одного героя к другому, из одного места действия в другое. Таким образом достигается впечатление о соответствии во времени, синхронности событий, происходящих с героями в данное время.

В героических ненецких песнях сюдбабц слово-песня выступает в роли автора. Об этом писала исследователь-фольклорист Куприянова ${ }^{14}$. Слово-песня в сюдбабц и ярабц - эпических, героических и бытовых песнях - находит героев, о которых будет рассказывать, знакомит читателя с ними, дает им имена. Далее оно выступает в роли активного действующего лица, которое не только наблюдает за поступками героев, но и летает, несется по ветру, кружась, опускается в стойбище, слушает, о чем говорят герои, дает им свою оценку.

Наличие этого своеобразного «героя» в эпосе, ссылаясь на исследования этнографа и культуролога С. В. Иванова «Материалы по изобразительному искусству народов Сибири начала XX в.», объясняет Куприянова в своем диссертационном исследовании тем, что ненец в далеком прошлом, на заре развития своего мышления, каждое произносимое им слово представлял себе совер- 
шенно конкретно в виде зримого образа и наделял его способностью наблюдать, действовать, выражать свое отношение ко всему происходящему вокруг. По ее мнению, эти представления возникали до появления религиозных воззрений. Именно на основе этих древних представлений появляется позднее магическое значение слова, т. е. уже ранние религиозные верования ${ }^{15}$.

Исследователь С. В. Иванов, анализируя художественное мышление долган, у которых как и у ненцев существует образ слова-песни, писал о их вере в материальность мысли. Они отгоняли от себя мысль о том, что будут убивать диких оленей во время охоты, так как мысль могла выйти из головы человека через рот и предупредить оленей, и они убегут в сторону.

«Еще более неожиданным являются представления долганов о том, что слова человека, рассказывающего сказку или былину, превращаются в материальные образы, видимые животными и духами. Эти образы не статичны, они действуют, движутся, соответственно тексту рассказа, но тоже не являются духами» ${ }^{16}$.

Он утверждал, что это были ранние формы общественного сознания, предшествовавшие появлению религиозных представлений у народов. Кроме того, эти же факты «вскрывают, с нашей точки зрения, древнейшие формы художественного мышления... Для нас весьма существенно, что образ конкретного предмета в сознании человека, тень от этого предмета и произнесенное слово, обозначающее этот предмет, отождествлялись, что слову приписывалась способность превращаться в зрительный образ, который также мог быть видимым, как и любой предмет» ${ }^{17}$.

Теоретик литературоведения Татьяна Касаткина во введении книги «О творящей природе слова», обратившись к совокупности наук о слове, обосновывает «подход, позволяющий впервые заметить некоторые вещи как в художественном произведении, так и в категориях, при помощи которых анализируется литературный процесс» ${ }^{18}$. Предложенный ею подход опирается на особое восприятие слова, поскольку «от того, как понимается слово, зависит решение самых “неразрешимых" теоретических проблем литературоведения, зависит определение и функционирование его основных категорий (например, жанра и стиля) и, конечно, зависят способы анализа и интерпретации конкретных художественных произведений» ${ }^{19}$. Исследователь направляет внимание литературоведов на понимание «истинной жизни слова», его порождающей природы. 
Изучение истоков литератур коренных народов Севера, вероятно, необходимо осуществлять с обращения к процессу «вочеловечивания» Логоса, к тому, как слово постепенно входило в сферу онтологии, обретало самостоятельный бытийный статус. Каким он был в мифах, фольклоре, эпосе, представлен в литературе?

Рассматривая аспекты, в которых предстает лаханако (словомиф, слово-сказка) в мифах-сказках, Е. Т. Пушкарева выделяет три его разновидности: 1) «лаханако» - данный нарратив; 2) «лаханако» - повествователь, «автор» данного нарратива; 3) «лаханако» - персонаж, некая одушевленная субстанция слова. По ее мнению, не всегда в одном повествовании присутствуют три аспекта, иногда фигурируют один или два. Она отмечает, что о присутствии «лаханако» рассказчик говорит очень редко, самое большое количество упоминаний в проанализированных ею пятидесяти пяти текстах - десять. «Это, видно, объясняется тем, что достаточно сказать один раз о том, что приходит “лаханако”, и он как бы присутствует во всем остальном повествовании» ${ }^{20}$. Слово выступает как собирающее, синтезирующее начало, связывающее воедино пространственную и временную разрозненность явлений.

В архаическом мифе «Тирлей» ${ }^{21}$ автор-рассказчик назван «лаханако» - сказка (букв.: слово). Начинается миф со слов «сказки»: «Сказка говорит: среди кедров, среди сосен, среди елей живут девять Тирлеев, питаются сосновыми, кедровыми орехами, ягодами, растущими на деревьях. Они не знают мясной и рыбной пищи. У девяти Тирлеев нет одежды, у них нет меховой одежды из оленя, они ходят обнаженными. Девять Тирлеев обычно так и ходят. Остановились в людном месте, играют, ложатся спать, встают».

Действие развивается далее без участия сказки, но о ее присутствии свидетельствуют вставки: «Дед ушел, видно, у него есть жилище, и старший из Тирлеев ушел домой. Сказка осталась на этом месте»; «Эти три человека поставили свой чум снова. Сказка осталась здесь».

Сказка обладает способностью предугадывать события, поскольку несмотря на то, что на том месте, где происходили события, было лишь пепелище от костра, на котором сожгли Ненай Хууся, и не осталось никого из героев, сказка не покинула его. И действительно, возрождение жизни на опустевшем пространстве состоялось. Появились новые действующие лица, знающие о происшедшем и продолжающие бороться за возрождение сожженного 
героя: «Наблюдает сказка, что женщина ноготь Ненай Хууся положила торчком под голову мужчины».

Сказка покидает место действия только для того, чтобы проследить за действиями героини, а возможно, и подсказать ей путь: «Сказка пошла с женщиной. Она пошла по следу девяти Тирлеев». Когда же героиня после частичного исполнения задуманного размышляет о том, что ей надо ночью уйти из чума, чтобы продолжить поиски Ненай Хууся, и уходит, сказка как бы на некоторое время оставляет ее и появляется рядом с нею уже при новых обстоятельствах. Происходит сокращение фабульного времени в пользу развития интереса к сюжету мифа. «Она пошла. Сказка ушла прочь». Далее сказка «видит», что девять Тирлеев свисают с деревьев, «лишь пощелкивают зубами во время еды», «слышит», как старший из них предлагает пойти на поиски. Своеобразно описано их движение, «увиденное» глазами сказки: «Шагают рядом, никто не отстает, когда двигаются, руки тоже не отстают». Повествование в мифе ведется от третьего лица, но иногда в содержание вмешивается рассказчик-информатор, а временами, как мы наблюдали, появляется образ сказки (слова). Сказка (слово) выступает и в роли автора, определяющего место действия, и в роли предсказателя будущих событий в другом месте, и в качестве наблюдателя за происходящим, и молчаливой советчицы героине.

Образ слова связывается с мыслью, которая, судя по фольклору и наблюдениям этнологов, у ненцев, как и других самодийских народов (долган, нганасан), также иных народов Севера, материальна. Во время охоты на диких оленей ненцы отгоняли от себя мысль о своей цели, чтобы она (мысль) не могла выйти из головы человека и предупредить оленей.

Исследуя древние формы художественного мышления народов Сибири XIX - начала XX века по материалам изобразительного искусства и фольклора, С. В. Иванов пришел к выводу, что у долган, например, слова человека, рассказывающие сказку или былину, превращаются в материальные образы, видимые животными и духами. Эти образы не статичны, они действуют, движутся, соответственно тексту рассказа, но тоже не являются духами. Автор убежден, что в сознании человека образ конкретного предмета, тень от него и произнесенное слово, обозначающее этот предмет, отождествлялись, и слову приписывалась способность превращаться в зрительный образ, который становился видимым, как и любой предмет. Позднее, с изменением мышле- 
ния и представлений образы слова, речи потеряли то значение, которое им приписывалось, и они остались в устном творчестве народа средством художественной изобразительности.

В глубинах древности открывается способность слова быть субститутом (заменителем) мира физической реальности. Слово рождается как экзистенция (духовное существование) сознания.

Постепенно мышление и представления менялись, трансформировались и образы слова, речи, они стали терять то значение, которое им приписывалось, и они остались лишь средством художественной изобразительности в фольклоре. Отсюда они были заимствованы в литературу.

Для бесписьменной культуры северян было характерно особое отношение к слову, основанное на представлении о слове как о сакральном объекте или даже субъекте. Считается, что слово может быть более действенным, чем само действие, и поэтому с ним надо обращаться очень осторожно. «Как олень волка боится, так и люди болтливого человека боятся», — говорят ненцы.

Если мы обратимся к ненецкой литературе, то заметим, что ненцы (герои, мужчины, в основном) понимают значение произнесенного слова, что каждое слово производит могучие следствия в какой-либо материи, поскольку энергетизировано двумя главными факторами: волей и мотивом. Они понимают необходимость быть чистым в мыслях, взвешенным в словах и искусным в действии.

Такое отношение к слову есть своеобразный метод воспроизведения архетипа - через эфирный план - через звуки, которые их активизируют.

В стихотворении «Твердят, что ненец молчалив...» П. Явтысый объясняет сдержанность в речи, нежелание вести длительные беседы и дискуссии не отсутствием мудрых слов или неумением вести беседы, как утверждают иные, а бережливостью ненцев по отношению к словам, их желанием вести разговор так, чтобы он не был лживым и пустым, окрылял и запоминался, «чтоб мысли в нем сплелись в узор, / смысл - чтоб был, как чай, густым».

Именно верой ненцев в сакральную силу слова можно объяснить, например, поведение, поступки многих героев произведений В. Ледкова. Клятва, обещание были священны. Об этом писал известный собиратель устного творчества ненцев финский фольклорист Кастрен в книге «Путешествие...». Если ненцы подозревают кого-либо в краже, то призывают к присяге. «Он де- 
лает тогда Хахе из камня, дерева, земли или снега, приводит к нему своего противника, закалывает собаку, разбивает сделанного им истукана и говорит, обращаясь к подозреваемому в покраже: “если ты украл, то погибни, как эта собака”. Этой клятвы самоеды боятся так, что действительный вор скорее сознается, чем допустит до нее. Иногда вместо Хахе употребляют при этом обряде морду медведя, которую разрезают на куски, и это еще страшнее. Медведь - божество и даже могущественнее Хахея» ${ }^{22}$. Отсюда родилась и пословица, подтверждающая значимость клятвы: «Пусть сожрет меня медведь, если я клянусь ложно».

В художественных произведениях авторы используют традиционное отношение к слову-клятве как для создания образов, так и для построения сюжета. Василий Ледков в отрывках из предполагаемой повести, названных «Свадьба» и напечатанных в сборнике «Северное сияние» ${ }^{23}$, ярко и убедительно представляет терзания героя Микиты Салиндера из-за того, что его дочь отказалась уехать из интерната и выйти замуж за Едейко, с родителями которого год назад он договорился о дне их бракосочетания. Трагично в этой ситуации для героя то, что он не может, возвратившись из поселка в стойбище, придумать какой-либо предлог, солгать. «Микита должен сказать правду... В тундре не говорят неправду. Таков закон. Его все чтут свято. И Микита бережет. Этому учит людей сама земля. Солгать Микита не может». Он вслух самому себе рисует безрадостную картину, как приехавшие на свадьбу жители Большеземельской тундры смеются над ним, а жених проклинает его. Действие будущего проклятья больше всего пугает Микиту.

Как видим, слово, сказанное себе вслух, осознается ненцами и воздействует глубже, как выпущенное на простор.

Необходимость нарушить данное слово вызывает у героя гнев - он ударил непослушную дочь, загнал своих оленей, так что два из них упали почти замертво и ему пришлось идти пешком до дома. И окружающее пространство, и будущее время кажутся герою настроенными против него. Стараясь успокоить себя, он всматривается в холодную синеву тундры. Небо как бы грозит Миките новым днем, когда в его чум хлынут люди со всей Большеземельской тундры, чтобы осудить его.

Пытаясь оправдать себя, герой винит прежде всего новые социальные установки, уводящие молодежь от беспрекословного подчинения родительскому слову. Отцу трудно признать, что он нарушил обещание отдать свою дочь, стал как бы клятвопре- 
ступником. И все-таки он решается на предупредительный одиночный выстрел, извещающий о том, что свадьбы не будет. Сделав его, Микита почувствовал облегчение, но «в душе его что-то надломилось». Нарушение данного слова стало для героя трудным испытанием, вызвавшим нервное потрясение. Становление нового мировидения осуществлялось в конфликтах, испытывавших ненцев на психологическую устойчивость.

Автор представил пример умения мужчин в экстремальной ситуации овладеть своими эмоциями, воздержаться от крайних мер, с одной стороны, а с другой - высветил специфическое отношение ненцев к слову как своеобразному закону организации жизни.

Подчеркивая значимость напутственных слов восьмилетнему мальчику, который остался сиротой, Анна Неркаги в повести «Илир» как бы предостерегает взрослых от того, чтобы не перегружали юные души своим суровым опытом. «Не знал он, что, отравленная ядом обид, старая исстрадавшаяся душа Варнэ передавала сейчас свою страшную ношу молодой, думая этим оберечь ее от людской жестокости. И его неокрепшая, совсем еще юная душа принимала эту тяжкую ношу не колеблясь и не задумываясь». Варнэ поучала: «Человек - это остро отточенный нож. Если не хочешь пораниться, будь ножом, отточенным с двух сторон. - Яд слов падал мерно, подобно весенней капели, и старая душа с каждой отданной частицей горького опыта ослабевала, становилась прозрачней».

Автор образно представила явление катарсиса - очищения с помощью словесной передачи душевного груза другому человеку, юному существу, способному активно воспринять сказанное.

Своеобразным лейтмотивом повести Л. Ненянг «Звон оленьих рогов» является слово «нгэлирэй», раскрывающее специфику ненецкой речи, объясняющее избирательность и сдержанность ненцев в разговоре. Ненянг художественно высвечивает многозначность, смысловое богатство таинственного, богатого эмоционально слова «нгэлирэй». Сначала перед читателем возникает картина первой встречи мальчика Ламдо с безбрежным оленьим стадом. Малыш, раскинув руки, старается попасть в такт с плавно колышащимся лесом рогов. Завороженно глядя на оленей, он улыбается и про себя проговаривает: «Нгэлирэй». Автор объясняет: «Это значит - мальчик в восторге, он удивлен, заворожен. Наверное, все здесь, в этом слове, есть. И вместе с тем в нем не только это. Открывает мир? Стремится охватить увиденное и на- 
всегда оставить в душе? Да, да. И об этом, об этом - нгэлирэй». Наполняя смысл слова, Ненянг уточняет, как его воспринимает Ламдо, став взрослым. Он объясняет русскому другу значение этого красиво звучащего слова. «Понимать как? А вот так... Смотрят глаза и удивляются - нгэлирэй. Не понимают, широко открылись - нгэлирэй. Весь мир хотят охватить. Вот взглянули на что и хотят навсегда унести с собой увиденное. Нгэлирэй...» Именно это объяснение сделало понятной для русского юноши молчаливость ненецкого друга, которую он переносил и на весь незнакомый ему народ. Русский юноша Никита удивляется: «Я всегда думал, ты это так, сам по себе застенчивый. Скажешь слово и молчишь. Опять скажешь, в самую точку, и рот на замок. А выходит, народ немногословный. "Нгэлирэй”, а видишь, как много».

В третий раз автор представляет слово «нгэлирэй» как выражение эмоции, подготавливающей принятие жизненно важного решения. У живущего в городе Ламдо появляется мысль вернуться к оленеводам, чтобы помочь им внедрить в быт достижения цивилизации, создать новые условия пастушеского труда. Герой еще не признается в этом внезапно возникшем решении, он только внимательно слушает беседу руководителя с участниками совещания оленеводов, но уже начинает представлять поновому организованный быт, работу, отдых и произносит про себя: «Нгэлирэй».

Любовь Ненянг образно представила читателям, как выразительны и многозначны ненецкие слова. В ненецком языке нет формул вежливости - приветствия, прощания, приглашения, благодарности. Поблагодарить - значит ответить на дар, тогда как ответом должен быть равноценный дар (услуга, вещь). Когда трудно ответить партнеру по коммуникации программой поведения, не прибегая к языку, используют намеки, иносказания. Языковое клише часто имеет акциональный аналог. Выбор вербального или акционального варианта порой имеет окказиональный характер. Употребление косвенных выражений имеет своей целью избежать прямых и резких формулировок своих намерений по отношению к партнеру по взаимодействию, своих ожиданий от него. Так, например, просьба выслушать содержит клише «у меня есть слово», и пока собеседник не произнесет «отзыв»: «какое слово, говори», это самое «слово» не может быть высказано.

И в фольклоре, и в произведениях литературы нашло отражение правило ненцев не говорить плохих вестей без разрешения собеседника. Так, в повести Неркаги «Илир» приехавший в стой- 
бище Маймы Кривой Глаз прежде чем сообщить о смерти отца хозяина стойбища предупреждает: «Слово у меня нехорошее» и только после ответа, поощряющего собеседника: «От плохого слова еще никто не умирал», рассказывает о трагедии.

Придавая большое значение воздействию слова, герои не тревожат понапрасну плохими вестями. Когда в повести Неркаги «Анико из рода Ного» герой отправляет Алешку искать неприехавших вовремя женщину с ребенком, то советует не говорить о том, куда поехал, никому в стойбище, а матери сказать, «что олень ночью от стада отбился. Надо, мол, искать».

Перед тем, как сообщить плохую весть, не только спрашивают разрешения, но и настраивают собеседника на спокойный лад в случае необходимости рассказать о случившемся. Прежде чем рассказать Себерую о гибели его жены и маленькой дочери, Алешка обращается к нему: «Отец, пусть у тебя сердце будет больше неба».

При прощании с погибшей Некочи жители стойбища уверены, что в этот момент пришли многие близкие, покинувшие раньше этот мир. Они якобы слушают ее рассказ и слышат их голоса, поэтому нельзя молчать в это время. Надо передать с ней просьбы, рассказать, кто как живет в стойбище, замолвить слово за оставшихся жить, отдать подарки родственникам. Они варят мясо оленя и предлагают отведать последний раз. Кроме того, при всех дают обещания заботиться об оставшихся. Пасса, друг Себеруя, обещает: «А за отца Анико не бойся. Сама знаешь, хорошо жили. И оленя делили, и чай, а теперь горе его, как еду поделим». Пасса просит передать своему умершему отцу, что выполняет данное ему обещание позаботиться о младших братьях.

Тщательная разработанность акционального кода и его самостоятельность по отношению к вербальному, а иногда и доминирующее положение, проявляются и в современной жизни, отражаются в литературе. Регламентированность речи свойственна тем ненцам, которые живут постоянно в окружении соблюдающих эти правила. Незнание их - свидетельство оторванности от жизни в родном крае. Так, воспитанная в интернате и не приезжавшая четырнадцать лет в стойбище главная героиня повести Неркаги «Анико из рода Ного» молча сидела за столом и пила чай. За столом повисло молчание. Оказалось, что это она его виновница. «Откуда ей было знать, что разговор за гостем, а за хозяевами - стол». 
О сдержанности ненцев пишет А. Пичков в стихотворении «Мы лирику храним у сердца свято...», подчеркивая умение своего народа слышать, понимать и плач ветра, и жалобный крик попавшего в капкан зверя, но не выплескивать чувства, а сдерживать, накапливая: «И мы храним в душе своей тепло / Лирических взволнованных раздумий».

Ненецкая литература, как и литературы других народов Севеpa, предоставляет возможность осмысления народных форм постижения бытия, поэтизируя его. Поэты и писатели акцентируют внимание на теме Слова, стремясь раскрыть его жизненно важную и многоцелевую роль, сакральность его и действенность, магическую силу, поддерживающую творческий процесс. Ненецкий поэт А. Пичков сравнивает творческий процесс стихосложения с таинственными природными явлениями, с появлением птенцов, крылья которых постепенно набирают силу. Сравнение поэта есть своеобразная интерпретация бытующего в ненецком фольклоре представления о «живом» слове», способном летать, обладающем способностью к самостоятельным действиям.

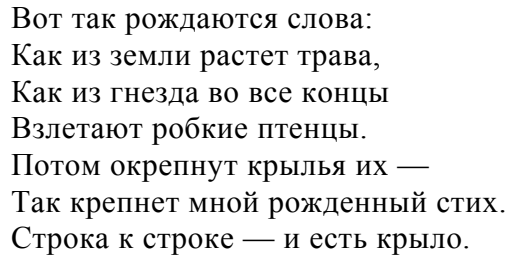

В мучениях находит автор магические, животворящие слова для своих стихов-песен, чтобы они смогли помочь в труде и рыбаку, и пастуху, вселяли в людей веру, обещая «радость и успех».

Дух и эстетика бессознательного воздействуют на воображение и становятся движущей силой творчества ненецких поэтов и писателей. Воображение активизируется чаще всего в условиях снижения сознательной интенции, времени грез. Марево весны, например, рождает у П. Явтысыя ощущение новизны, любви, тогда «слова любви на крыльях птиц взлетают / в звенящую безбрежность синевы! / Слова любви - стихами прорастают / сквозь теплый снег / сквозь ягель и сквозь сны». Образ любимой возникает среди цветов - символов весны. В стихотворениях «Когда снега в просторах тундры тают...» и «Вновь память юрким горностаем...» устремленный в будущее дух поэта пытается разгадать тайны судьбы, возвращаясь периодически в прошлое. В соединении прошлого, настоящего и будущего - ключ к рожде- 
нию его стихов. Творческое самовыражение поэта сроднилось с грезами, в них и проявились смысловые отголоски и народного, и субъективного опыта, которыми он осознанно зарядил грезы.

В стихотворении «Освободясь от суетного гнета» (из цикла «Вечная связь» о силе влияния первопредков) П. Явтысый метафорически описывает возникновение моментов особого видения окружающего. Увидеть жизнь «на тундру глядя с птичьего полета» ему помогает марево напоенного влагой весеннего дня, склоняющегося к вечеру. С наступлением глубоких сумерек - поры зыбкого нервного состояния, когда теряется концентрация внимания, поэт почти впадает в состояние транса, у него появляются «зыбкие грёзы». Ощутив «колдовскую явь» вешней тундры, сумерек, поэт начинает записывать льющиеся потоком поэтические строчки.

В стихах Явтысыя обозначена таинственная животворная связь творческого процесса с предками, с бессознательным одухотворением архетипа предков, с его пластическим оформлением в цикле стихов. Такое художественное развертывание праобраза предков становится своеобычным переводом его на язык современности. Архетип получает возможность вновь обрести доступ к глубочайшим источникам жизни, которые иначе остались бы за семью замками.

Леонид Лапцуй также приоткрывает читателю тайну своего поэтического творчества:

А мне мои стихи ночами снятся,

И что-то шепчут в уши,

И толпятся,

И сердце распирают - хоть кричи!

Состояние полудремы, полусна пробуждает особое видение природы и явно слышимые и ярко видимые воспоминания у лирического героя из стихотворения В. Ледкова «Дня ослаблен порыв...». Это время, когда «день тревожный застыл в спячке древней. /Ночь, уняв его пыл, тоже дремлет». И возникает творческий запал. Рождаются стихи и во время утреннего пробуждения, когда сочинитель еще «окутан рассветными снами».

Фантазии становятся естественным проявлением и манифестацией жизни бессознательного. Первообразы посредничают между бессознательными основами и сознанием, объединяя противоположности. Они наводят мосты между нынешним сознанием и естественной бессознательной целостностью седой старины. Активная имагинация, намеренная концентрация делают порой фантазии поэтов явью. Сны, тайные мечты переходят в 
реальность, воплощаются в стихи, в которых предстает особое видение окружающего мира.

Продукты фантазии как мифологического, коллективного бессознательного, так и индивидуального типа, как свидетельствуют вышеприведенные примеры из ненецкой поэзии, возникают зачастую в состоянии пониженной интенсивности сознания (в сновидениях, грезах, делириях, видениях и т. д.). В таких состояниях концентрация сознания становится меньше, и содержание, выходящее из бессознательного, не оттормаживается. Неосознаваемый ранее материал устремляется как будто из распахнутых кулис в пространство сознания. Во сне снимаются барьеры сознания и его цензурирующая роль, - утверждал Фрейд, - тогда фантазия проявляет свою власть, а она самый верный помощник.

С особым состоянием духа связывал творческое вдохновение Густав Шпет во «Введении в этническую психологию». По его мнению, это состояние творца охватывает человека целиком, и даже «захватывает». «Дух» здесь не есть особая «способность» или «часть», здесь не может быть также многих «духов», как не может быть речи об абстрактном значении его. Это есть просто особый «строй», не только не «постоянный», но даже сравнительно не очень длительный, — «дух», «настроение», «расположение». «Может быть, наиболее характерной и существенной особенностью для “духа” в этом значении является то, что как состояние он охватывает субъекта помимо его воли и индивидуальных усилий. Это есть “вдохновение” или "наитие”, источник которых мы ищем вне собственных сил, в сферах, лежащих выше их... индивид входит с ним в “общение" и именно постольку переживает “духовное состояние”» ${ }^{24}$. Литературное творчество рассматривается как постижение мира иными, не рассудочными путями. Это то, что в других областях называют откровением. Создание литературных произведений, других артефактов искусства иногда называют приотворенными дверьми в Вечность. Только художник порывом творческого вдохновения способен прорваться за грань реального бытия, «овладеть не связями и закономерностями природного мира, а идеей, живой сущностью явлений».

Вдохновение и откровение - важнейшие этапы творческого процесса - и способствовали взаимодействию художественного сознания ненецких поэтов и писателей с мифологическим пластом духовной культуры, с архетипами.

Скорбны, грустны стихи поэтов-ненцев о возможной потере родного языка, исчезновении народных традиций. П. Явтысый в 
стихотворении «Сквозь даль судьбы...» сожалеет о том, что разрушается связь времен, поскольку «бездумно обрубали корневища» и «как птичье оперение при линьке, теряли мы традиции, язык». Его радуют новые времена, когда люди, увидев столь безрадостную картину разрушения, осознавшие важность обращения к прошлому для развития народа, стремятся возродить язык и добрые традиции. По мнению автора, «К достоинству стремясь сквозь стыд и страх, нужны нам имена оленных предков, как добрая улыбка на устах».

Слово интегрирует культурно-историческую память. Оно является одновременно и символом, и знаком. В качестве символа - многозначно, в качестве знака - однозначно. В качестве символа слово обладает огромной действенной силой. Смыслы заклинаний зачастую не осознаются, но они, минуя сознание, воздействуют прямо на подсознание, а через него и на соматические структуры человека, вызывая в нем смутные образы и неясные воспоминания и побуждая его к определенным действиям, на чем и базируется магическая сила слова. Наибольшей магической силой, по Флоренскому, обладают термины и имена, особенно личные, поскольку они изначальны на жизненном пути.

Одно из будущих направлений в постижении символики слов, их творящей природы - освоение поэтики имен в северных литературах. Своеобразная поэтика и значимость чукотских имен, например, отмечена в стихотворении чукотского поэта Вальгиргина в сборнике «Чукотская литература» прозаиком Александром Трапезниковым ${ }^{25}$. Для убедительности приводим текст стихотворения - размышления поэта об именах:

Мой отец Тынагиргин

и Кергина мать

Старший брат Турваургин

Тумгине сестрёнку звать.

И привыкла радуясь

жить моя родня...

Тундра - словно радуга

среди бела дня...

Если явится ко мне

сон мой наяву,

Непременно Тиркине

дочку назову...

Это имя всех светлей, каждому понравится, и у всей родни моей радости прибавится. 
Особенность имен скрыта в значимости чукотских имен: Тынагиргин - «рассвет», Кергина - «светлая», Турваургин «новая жизнь», Тумгине - «подруга», Тиркине - «солнечная».

Смысловая значимость ненецких имен, их происхождение также нередко раскрывается и ненецкими писателями, иногда с помощью бытующих в народе легенд.

В повести В. Ледкова «Синева в аркане» завязка действия включает беседу о происхождении имен. Чтобы предъявить читателю своего героя как человека, размышляющего о своих истоках, стремящегося в выгодном свете рассказать о своем народе, писатель вводит легенду о генезисе имени Паханзеда. Оно связано, как и многие ненецкие имена, с названием рода, чаще всего - с местоположением родового стойбища предков. В переводе на русский язык Паханзеда - сопка на берегу залива. Так, согласно легенде именовался род, живший в древности у подножия Крутой сопки, и жители трехсот чумов. Были они рослыми, сильными и здоровыми, удачно охотились в море на нерпу и моржа, а в тундре - на дикого оленя и песца. Добычу богатую делили поровну и жили дружно, весело, «много раз слышали сопки веселые и шумные свадьбы».

Тревога за будущее рода возникла постепенно, когда стало людей больше умирать, чем рождалось, когда стали рождаться уроды без суставов в руках и ногах, хромые и слабоумные. Мудрый старейшина понаблюдав за семьями, где рождаются уроды, сравнил их с теми, в которых дети крепкие и здоровые, понял, что для здорового потомства нужны браки представителей разных родов. Пред собравшимися «с прилетом первых лебедей» жителями стойбища старейшина бросил клич: «И как бы ни была богата наша земля, ради спасения рода нам надо бросить ее. Ищите, Паханзеды, новую кровь себе! Нельзя брать в жены девушку из своего рода. Чем дальше найдет себе жену юноша, тем выше поднимет свой род! И в семь раз лучше, если жена будет из другого племени и языка!»

С тех пор род рассеялся по тундре, кто поселился в низовьях Оби, кто на Таймыре и берегах Енисея. Память же о земле первоначального обитания рода сохранилась в фамилиях и именах.

Легенда отражает не только происхождение названия рода, фамилии и имени Паханзеда, но и значимость предков этого рода в спасении замкнуто живущих ненцев от вымирания из-за неизбежно возникающего инцеста. 
Геоландшафтным расположением стойбища ненцев из рода Паханзеда, откочевавших в долину Большеземельской тундры, объясняет автор возникновение фамилии Ледков: «А долина или низина по-ненецки - “лед”, маленькая - “ледко”. С приходом в тундру русских появилось слово - Ледков».

Генезис имен и фамилий, художественно изложенный автором в диалоге героев - отражение судьбы древнего ненецкого рода, частицы истории народа.

Неркаги в повести «Илир» выстраивает характеры героев в тесной связи с их именами, кличками, перешедшими в имена. Начинается повесть неправдоподобно страшными словами хитрого и злого, лукавого и умеющего использовать свои слова в корыстных целях оленевода по имени Кривой Глаз. Он пугает всех присутствующих во время беседы сообщением о том, что солнце стало всходить с другой стороны, с той, «где прячется ночь», и стало черным. И хотя в реальность произнесенного никто не поверил, все посмотрели невольно на верхнее отверстие чума, а в мыслях некоторых появился страх. Так умело Кривой Глаз воспользовался придуманной метафорой, чтобы представить в черном свете создавшееся положение в связи с социальными изменениями.

Автор объясняет происхождение имени героя особенностью его речи и способностью видеть и представлять действительность в ином свете: «...пока Кривой Глаз доберется до главного, долго еще будет лукавить да извиваться, как щука под палкой. Он и имя-то свое получил не за то, что правый глаз так сильно косил, словно хотел подсмотреть, что там, за спиной, а за то, что все в жизни видел в кривом свете. Придумывал небылицы, был нечист на руку, и разговор его походил на хитрый, запутанный след».

Герои называют собеседников по имени, согласно традициям, только в очень важные и ответственные моменты, поэтому все присутствующие в чуме во время рассказа Кривого Глаза о Красных нартах замолчали и насторожились, когда тот назвал имя хозяина чума: «Я говорю правду, Мерча». Обращение по имени подчеркнуло остроту момента, нацелило на серьезное отношение к событию.

Имя в повести Неркаги использует для создания образов, психологической характеристики героев. Имена героев меняются в зависимости от их жизненных обстоятельств, повлиявших на судьбу. Так, читатель знакомится с героиней по имени Варнэ, что означает «ворона», и мысленно видит пугающую всех неаде- 
кватным поведением старую женщину. Постепенно автор раскрывает причины «вынужденного сумасшествия» женщины, приоткрывает завесу над ее истинным состоянием и, чтобы подчеркнуть ее доброту и человечность, знакомит со светлым именем, которое дали ей родители - Эдейне.

Имена некоторых героев в повести «Илир», например, отсутствуют. Их автор называет так, как было принято у ненцев - по степени родства. Старшая жена Маймы называется еще «матерью Хона», вторая жена зовется просто «молодой женой». Одна из причин - сакральность имен, желание скрыть и защитить человека от злых духов, поскольку имя - это одухотворенное, «живое» слово.

Первообразы, среди которых и Логос как многогранная, таинственная мифологическая сущность, активно участвуют в литературном процессе, осуществляя связь трансцендентного с жизненным миром как творцов самобытных литератур народов Севера, так и героев их произведений.

${ }^{1}$ В истории отечественной науки проблема первообразов, мифологического сознания, в том числе и творческого сознания, рассматривалась отечественными учеными уже в XIX веке. В трудах Ф. И. Буслаева, А. К. Афанасьева, А. А. Потебни, А. Н. Веселовского уделено значительное внимание поиску первоэлементов, схем, формул, мотивов, лежащих в основе мифологии и мифопоэтических текстов. Как правило, их называли «мифами» или «первообразами», реже - «коренными понятиями человечества». В наши дни широко используется впервые введённое в XX веке швейцарским психоаналитиком К. Г. Юнгом понятие - архетипы (греч. arxetypos - «первообраз»). В сборнике «Литературные архетипы и универсалии» (М., 2001) исследователи, в частности Г. Е. Мелетинский, А. Л. Топорков, излагают собственное видение проблемы, по-новому осмысляют первообразы. Термин «первообраз», бытовавший и бытующий в отдельных исследованиях на русском языке, более точен и не привязывает первоэлементы только к психологическому анализу, примиряет рациональный и иррациональный подходы к изучению. Он (термин «первообраз») позволяет выделять матричные представления и первобытную логику, которые приближают к разгадке кодов, служащих для понимания различных моделей мира.

${ }^{2}$ Марр Н. Я. Этапы развития яфетической теории // Марр Н. Я. Избранные работы. Т. 1. Л., 1933.

Исследуя мифообразование, Н. Марр предполагал существование двух стадий развития первобытного мышления: тотемистической и космической. 
3 Леви-Брюль Л. Первобытное мышление / Пер. с фр. / Предисловие Н. Я. Марpa. М., 1930.

Стадиальная теория развития первобытного мышления Н. Марра возникла не без влияния идей французского философа и этнолога, изложенных в книге, предисловие к которой было написано академиком Марром.

${ }^{4}$ По Марру, «письменный звуковой язык длится от 5 до 10 тысяч лет, звуковой в общем от 50000 до 500000 и более ручной стандартизированный язык от миллиона до полутора миллионов лет» // Марр Н. Я. Язык и мышление. М.;Л., 1931. С. 58.

${ }^{5}$ Беликов Л. В. Особенности формирования повествовательных жанров в чукотском фольклоре // Фольклор и этнография народов Севера. Межвузовский сборник научных трудов. Л., 1986. С. 16.

${ }^{6}$ Там же. С. 17.

7 Борисов А. А. У самоедов, от Пинеги до Карского моря. СПб., 1907. C. 75 .

${ }^{8}$ Хорей (ненец.) - длинный шест, палка с металлическим наконечником для управления оленьей упряжкой.

${ }^{9}$ Юнг К. Г. Бог и бессознательное. М., 1998. С. 156.

10 Заметь - вьюга, пурга.

${ }^{11}$ Мелетинский Е. М. Происхождение героического эпоса. М., 1963. С. 95.

12 Леви-Брюль Л. Сверхъестественное в первобытном мышлении. М., 1999. C. 29.

${ }^{13}$ Там же. С. 77.

${ }^{14}$ Ненецкий фольклор / Составитель 3. Н. Куприянова. Л., 1960.

15 Куприянова 3. Н. Основные жанры ненецкого (юрако-самоедского) фольклора. Автореф. дисс. ... канд. филол. наук. Л., 1960. С. 129.

${ }^{16}$ Иванов С. В. Древние представления некоторых народов Сибири о слове, мысли и образе // Страны и народы Востока. Вып. 17. Кн. 3. М., 1975. С. 750.

${ }^{17}$ Там же. С. 750.

${ }^{18}$ Касаткина Т. А. О творящей природе слова. Онтологичность слова в творчестве Ф. М. Достоевского как основа «реализма в высшем смысле». M., 2004. C. 7

19 Там же. С. 9.

20 Пушкарева Е. Т. Миф-сказка в фольклоре ненцев: историческая типология и этническая специфика. Автореф. дисс. ... канд. ист. наук. С. 17.

${ }^{21}$ Миф записан фольклористом Е. Т. Пушкаревой во время экспедиции в Ямало-Ненецком АО от информатора Ядне Осьми на Первой речке поселка Антипаюта Тазовского района.

${ }^{22}$ Кастрен М. А. Путешествие по Лапландии, Северной России и Сибири // Магазин землеведения и путешествий. СПб., 1860. Т. VI. Ч. 11.

${ }^{23}$ Северное сияние. Л., 1987. С. 259-268.

24 Шпет Г. Г. Введение в этническую психологию // Шпет Г. Г. Философско-психологические труды. М., 2005. С. 39.

${ }^{25}$ Трапезников А. Семилистник // Чукотская литература. М., 2007. С. 312. 


\section{Глава 3}

\section{ЗООМОРФНЫЕ МИФОЛОГИЧЕСКИЕ ОБРАЗЫ}

Выражая мироощущение и миропонимание человека, миф затрагивает все волнующие человека коренные вопросы мироздания, в том числе метафизическую и онтологическую связь с животным миром.

Раскрытие зооморфной семантики в литературе ненцев, выявление зооморфных мифологем, определение роли зоонимов в развитии сюжетов и мотивов, создании образов, наряду с другими художественными приемами, дает возможность реконструкции древних представлений народов Севера об устройстве мира. Поэтическая переработка знания о мировидении значительно повышает значимость познавательной функции литературы в ретрансляции культурной памяти в определении координат человеческого опыта.

Раскодирование зооморфных образов в литературе возможно лишь в контексте с данными, накопленными не только мифологией и фольклором, но и этнографией, археологией и другими науками. Исследуя древнюю культуру народов европейского и азиатского северо-востока, археолог и этнограф А. П. Окладников пришел к выводу, что многие народы олицетворяли стихии природы, небо и землю в виде живых существ, наделяли их сознанием, чувствами и волей, предполагал, что были эти «живые олицетворения стихий природы, даже самой Вселенной, скорее всего, зооморфные» ${ }^{1}$.

Развивая мысль о возникновении зоопатрических культов, В. Н. Топоров предположил, что именно животные могли использоваться как модель жизни человеческого общества и природы в целом (прежде всего в аспекте плодородия и цикличности), поскольку служили для человека в течение длительного времени «некоей наглядной парадигмой». Он утверждал: «В мифологическом 
сознании животные выступают как один из вариантов мифологического кода» ${ }^{2}$. Символические образы животных в ненецкой народной традиции связаны как с видовыми особенностями животных, так и со специфическим характером жизнедеятельности народа. Используя и обновляя мифические и сказочные образы, мотивы, сюжеты в сочетании с жизненным материалом истории и современности, поэты и прозаики расширили познавательное поле ненецкой культуры. Выявление же коннотативных значений культурных кодов в их произведениях позволяет обнаружить специфику мировидения народа, а также обеспечить однозначное (более точное) прочтение их (литературных произведений).

Обращение к текстам с целью создания концепта «мифопоэтическая картина мира ненцев», определение универсальных и этноспецифических особенностей в видении мира потребовало привлечения материала о культурах других народов, поскольку образы животных в разных культурах наделяются не всегда мотивированными, а иногда противоречащими логике, свойствами и качествами. Было важно найти истоки представлений в глубинах человеческого сознания, обращаясь к мифологии, фольклору, литературе разных народов, в особенности психологии народов, проживающих на Крайнем Севере. Мифологемы животных в художественных произведениях этих народов могут способствовать определению как различного, так и общего в национальных культурных представлениях, уточнению ментальных, психологических и социальных особенностей и разнообразных обычаев, традиций.

Предполагалось, что изучение функционирования зооморфизмов в ненецкой литературе поможет не только расширить фоновые знания и культурные ассоциации народа, но и проявить особенности самопознания ненцев, их универсальные и этноспецифические качества.

Как ненецкие писатели и поэты создавали художественные образы своих произведений, привлекая представителей животного мира? Какие зоонимы, зооморфизмы являются в произведениях важной составной частью содержания и, соответственно, отражением мифологического видения как героев, так и самих авторов?

Василий Ледков в стихотворении «В тундре» круговорот и смену времен года, природные изменения тесно связывает с постоянно меняющимся в северных просторах животным миром. 
Его метафоры наполнены зоонимами. Читателю представлен суровый край как локус красоты и бурной жизни.

\author{
Там плавают зори весной \\ Красноперою рыбой. \\ Там месяц на сопке \\ Совенком сидит, желторот... \\ Ясное лето \\ На птичьих базарах судачит, \\ И только умолкнет \\ Взволнованных птиц кутерьма, \\ спешат куропатки \\ на сходки свои куропачьи, \\ как будто поземку \\ вперед высылает зима.
}

Раскрывая цикличность природных процессов, Леонид Лапцуй при поддержке метафор с присутствием зоонимов поэтизирует жизнь в тундре в каждое из четырех времен года в стихотворении «Радуга жизни», где особенно яркими красками наделяет весну:

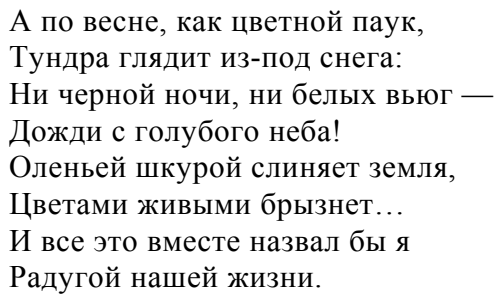

Размышляя о круговороте явлений природы, об исчезновении снега, его умирании, Алексей Пичков в стихотворении «Через снег и пургу, через звезд вековое сиянье...» сопоставляет это явление природы с возвращением птиц:

«Обогретые мартовским солнцем улетают куда-то метели // На растаявших крыльях им уже не вернуться назад».

И вдохновение к поэту, по его признанию, прилетает «на крыльях туч». О своем творческом процессе Пичков пишет, связывая слова с птенцами, постепенно обретающими крылья:

Вот так рождаются слова:

Как на земле растет трава,

Как из гнезда во все концы

Взлетают робкие птенцы.

Потом окрепнут крылья их -

Так крепнет мной рожденный стих. 
Ненецкие поэты и прозаики часто используют зооморфизмы как для характеристики неживых объектов через свойства живых («биоморфизация» неживой природы), так и для изображения живых объектов через свойства неживых («дебиологизация» живых объектов). Зооморфический компонент в символах, метафоpax ненецких творцов основан на мифологии и служит не только для создания образной речи, но и для создания художественных образов, отражающих национальное мировидение. На животных проецируются понятия и чувства, источник которых оказывается не в них, а в ассоциациях, которые они вызывают в сознании, проявляются формирующиеся нравственные установки, например, сочувствие. Руссо в работе «Рассуждения о неравенстве» утверждал, что сострадание, вытекающее из отождествления себя с другим - не родственным, не близким, не соотечественником, а просто с любым человеком, поскольку тот является человеком, более того, с любым другим живым существом, поскольку оно живое, появилось еще в первобытном состоянии.

Поэт Юрий Вэлла использует отождествление пастуха с оленями: животные прониклись сочувствием к своему защитнику, влюбленному и страдающему в отдалении от любимой:

Сегодня гнал на стойбище стадо.

Вдруг олени остановились

И удивленно оглянулись на меня...

Что-то, наверное, во мне изменилось

От писем твоих...

(Юрий Вэлла. Земля любви. Диалоги)

В процессе анализа прозы и поэзии ненцев предпринята попытка раскодировать зооморфные образы с привлечением данных, накопленных мифологией, фольклором, этнографией, археологией. Представлялось актуальным определение значимости в текстах мифологем, посредством которых возможна реконструкция древних представлений об устройстве мира. Не менее важно уточнение приемов создания образов с использованием зооморфизмов, которые способствовали проявлению особой реальности внутреннего мира героев, их характеров, пониманию мотивов поведения. Создавая образы героев своего времени - сложного приобщения к новому социальному устройству - Василий Ледков постоянно использует зооморфемы, сравнивает поведение 
человека с поведением или определенным состоянием животных. Так, в романе «Люди Большой Медведицы» аналогия человека с «больными птицами», сравнение с ними председателя Хасавы художественно представляет метаморфозу превращения трудолюбивого и доброжелательного оленевода, каким был герой до избрания, в «распускающего руки», жадного и злого, «не видящего людей» руководителя. «Эта болезнь и у тундровых птиц встречается - у сов да куропаток. У них в пургу глаза защитной оболочкой затягиваются», - уточняют собравшиеся жители.

В первой части романа-дилогии «Месяц Малой Темноты» автор и герои часто употребляют при оценке состояния и поведения сравнение с зайцем. Свое презрительное отношение к беднякам богатый оленевод Тэси выражает словами «Эх, заячьи головы!» Во время раскулачивания хозяева больших стад угоняли их подальше от селений, прятали своих оленей. Воспользовавшись неспокойной обстановкой, некоторые из них пытались тайком отбить часть стада у соперников. Узнав о потере части своего стада, пострадавший от Тэси оленевод Одерма соглашается с пастухом не преследовать угонщиков: «Ох, и время проклятое!.. Сами мы от всего мира отколоты... Как зайцы мечемся, глаз людских боимся. А кому жаловаться?» Сравнение с зайцами символично, подчеркивает неуверенность людей, нестабильность положения оленеводов в наступившие новые времена. Зооморфные представления ненцев о зайце связаны с мифической историей появления и преображения этого животного. Согласно сказкемифу, создал зайца Нум, одарил его быстрыми ногами и ловкостью и спустил с неба на землю. Питался зверек мясом, жил «припеваючи». Однако Нга, брат Нума, владелец подземного мира, поймал однажды зайца, схватив за уши, которые вытянулись, и потребовал за сытую и спокойную жизнь на земле украсть у брата рукавицу. Заяц согласился и утащил рукавицу. Нум рассердился, узнав о проступке зайца, и ударил его по спине, сделав маленьким. Он резко поменял дальнейшую судьбу животного: «С этих пор будешь питаться травой и всех бояться. От каждого шороха будешь прятаться». От сильного удара Нума полетел заяц с седьмого неба на землю. Натерпевшись страху, по дороге цепляясь за кусты, потерял хвост. С тех пор заяц Тэваси всех боится и прячется, чтобы Нум его не нашел. В фольклоре и литературе укоренилось мнение о зайце как трусливом животном. У ненцев есть о нем целый ряд загадок, подчеркивающих то заячью трусливость: «Днём и ночью дрожит, всего боится», то 
его желание спрятаться: «В густом лесу два уголька носит». Эти представления о трусости зайца, о его постоянном стремлении спрятаться в ненецком фольклоре и литературе часто проецируются на человека.

Рассматривая проблемы психологии искусства, Л. С. Выготский отметил: «Каждое животное представляет заранее известный способ действия, поступка, оно есть раньше всего действующее лицо не в силу того или иного характера, а в силу общих свойств своей жизни» ${ }^{3}$. Издревле человека удивляли, признавались сверхъестественными способности животных выживать в совершенно неприемлемых для человека условиях, спать в течение зимы и не питаться, менять окраску, умение летать, плавать, строить гнезда. В литературе ненцев нашло отражение особое видение северными жителями окружающего мира и животных, сформированное как мифами, так и практической наблюдательностью охотников, рыболовов, оленеводов.

В стихотворении «Кладбище тайн» создать картину борьбы своих сородичей за выживание на берегу сурового Карского моря, подчеркнуть силу, отвагу и порой гибель морских зверобоев и рыболовов, помогает Лапцую сравнение с битвами в птичьем мире:

\section{А сородичи мои \\ Бились так в когтях беды, \\ Как у ястреба в когтях \\ Куропатка в смертный час.}

Хищный ястреб выступает здесь символом сурового моря, а его жертва куропатка олицетворяет бессилие морских охотников и рыболовов против штормовой водной пучины.

Мифологемы птии, их крыльев, их гнезд, мифологемы насекомых, зверей активно использует Анна Неркаги; с их помощью ей удается раскрыть психологическое состояние героев, объяснить причины сложившейся замысловатой ситуации, создать особый психологический настрой у читателя. Автор сравнивает состояние разбитой любви главного героя повести «Белый ягель» с опустевшим гнездом: «Алешка сел на постели. Он вдруг почувствовал, как около сердца или в нем образовалась пустота, словно в птичьем гнезде, откуда улетел последний птенец, оставив только пушок от перьев. Чем заполнить пустоту гнезда? Какая птица сложит усталые крылья, найдя в нем приют и ласку?»

Герой анализирует свое поведение, опираясь на образцы поведения птиц, насекомых, зверей, пытается найти оправдание своим поступкам. В окружающем человеческом бытии для него 
образцов нет - никто не сомневался, что поступает правильно, если при выборе невесты согласился исполнить родительскую волю, поступил в соответствии с древними традициями. Алешка же сомневается и не может сблизиться с выбранной матерью и живущей в его чуме невестой-женой, потому что любит уехавшую в город другую девушку. Постепенно герой начинает присматриваться к живущей в одном с ним чуме умелой и трудолюбивой девушке, пытается оценить свое отношение к ней. В этой самооценке поведения соучаствует подскочивший к нему кузнечик. Герой вспоминает детство и то, как он с мальчишками ловил и умерщвлял кузнечиков, и родители хвалили детей за это. Сейчас он начинает иначе видеть свои действия в детстве ведь кузнечики тоже живые существа и не заслуживают уничтожения из-за поверий. И это настраивает героя на более глубокие мысли, приводит к самооценке собственных поступков в реальное время. Он вспоминает, что в стойбище называли кузнечика «лижущим солнце», определяли его виновником того, что осенью солнечное тепло убывает, поскольку кузнечики в это время плодятся. Он предполагает, что, возможно, кузнечика в стойбище не любят за то, что не могут понять, чем может питаться это «нелепое существо» кроме солнечных лучей. Обращение к специальной литературе позволило найти объяснение, почему не только у ненцев, но и в западных культурах бытует мнение о кузнечиках как безответственно размножающихся насекомых, забирающих осенью солнце. Возникновению такого отношения, вероятно, способствовало то, что у кузнечика на правом надкрылье имеется перепонка, или зеркальце, которое обрамлено специальной рамкой. На левом же надкрылье есть зазубренная жилка, или смычок, который в момент стрекотания трется о рамку, а зеркальце усиливает звук и, отражая солнце, как бы забирает его себе. Кроме того, кузнечик прыгает хаотично. В повести Неркаги кузнечик стал своеобразным символом проявления мужской безответственности героя по отношению к заботящимся о нем женщинах: матери, обеспокоенной его одиноким будущим, и сосватанной не без его участия девушке, живущей в чуме. Именно кузнечик подтолкнул Алешку на раздумья о сложившейся безрадостной ситуации, помог оценить свое поведение взглядом иного «Я». Он вспоминает, что людей, живущих припеваючи, ненцы презрительно называют, как кузнечиков, - «солнцелизами», у него появляется страх: узнав обо всем, что происходит в его чуме, люди назовут и его этим «позорным именем». И тогда с та- 
ким клеймом ему придется ехать, как придет день, на Святилище. Страх перед именем «презренного солнцелиза» - это боязнь не узнать на Святилище Тайны Человеческой Души и в конце жизненного пути не услышать ликующей бессмертной песни души, похожей на гимн, довольствоваться лишь тоскливым воем одинокого зверя, «обиженного самим же собой».

Метафорический кузнечик стал в повести приемом раскрытия внутреннего мира героя, его своеобразного восприятия окружающего мира, его стремления к самоанализу.

Сравнивая себя с кузнечиком, Алешка называет трудолюбивых мать и невесту-жену паучками: «Две женщины, как два паучка, трудились, сохраняя в чистоте и в теплоте душу жилища». Они в две руки с обеих сторон разжигали огонь, ухаживали за ним, а он, увлеченный своими чувствами и переживаниями, словно не замечал их. Автор с помощью размышлений героя, его самоанализа, уточняет причину доброжелательного отношения ненцев к паукам: они питаются ягодами, кроме того, согласно поверьям, приносят достаток. Алешка с детства видел, как родственники, чуть приоткрыв дымчатую дверцу чума, следят за пасущимися у чума стадами пауков и готовы защитить их.

В мифопоэтических традициях разных народов с образом паука связываются как трудолюбие, профессиональные ремесленные навыки, добрые предзнаменования, так и холодная жестокость, жадность. Пауку приписывают колдовские способности. В магической медицине его используют для предохранения человека от болезней. Примером обращения к пауку как защитнику и помощнику во время болезни является общение больного от рождения, неспособного ходить из-за слабых ног мальчика Хона в повести Неркаги «Илир». Во время обострения болезни Хон предпочитал уходить от реального мира, от злобы отца, от жестокости его по отношению к окружающим, в фантастический, придуманный мир, где паучок становится ему другом и поддержкой. С ним он беседует о среднем мире и его обитателях людях, поскольку усатый важный паучок, по мнению мальчика, «умен и вежлив». Эти мысленные беседы - свидетельство доброты и стремления ребенка к свету, желания изменить атмосферу в чуме. Чтобы порадовать больного Хона, паучок всегда приносит во рту вкусные листики и лепестки, которые падают в воду с цветов. Когда же паучок во время мысленных бесед «сообщает», что все пауки живут дружной одной семьей и «задает вопрос», как живут люди в чуме, Хон отмалчивается. Этот вопрос, задан- 
ный паучком, его смущает, поскольку нельзя говорить о дружбе, если старого пастуха убили, а его друг Илир живет на одной нарте с собакой. Представляя этот разговор с паучком, мальчик проигрывает и свою реакцию на придуманные слова: от стыда за родных он закрывает глаза, чтобы не видеть насмешливый взгляд паучка. Неркаги с помощью мифологемы паука удалось не только выявить и убедительно продемонстрировать разрушительную силу гнева и ненависти среди людей, но и обратить внимание читателя на колдовскую силу пауков, на их способность поддержать человека в период болезни, раскрыть существовавшее у ненцев издревле мифологическое поверье. Из космологического мифа о первых днях творения мы узнаем о негативной коннотации паука, его происхождении. Когда Нум и Нга создали землю, они решили населить ее разными зверями и птицами. Нум сделал оленя, Нга - волка, чтобы тот ловил оленей и часть отдавал ему. Так они населили всю землю разными зверями. Нум сделал человека. Человек стал жить припеваючи на земле, где было много зверей и птиц. Став хозяином подземного мира, Нга был вечно голодным. Он не мог поймать себе на пропитание ни одного созданного Нумом животного. Тогда Нга рассердился на человека и решил съесть его. Ушел к себе под землю и стал думать, как бы поймать людей и зверей. Долго думал и решил сделать паука, который будет плести сети, куда будут попадать люди и животные. Когда сделал пауков, он научил их человеческой речи. Чтобы быстро паук бежал к жертве, сделал много ног. Он заставил пауков плести из человеческих волос с кладбища сети, ловить людей и зверей и приносить ему. Повеселел Нга и растолстел. Узнал Нум о пауках, рассердился, взял свой посох, стукнул им и превратил пауков в маленьких насекомых, велел питаться насекомыми, которых создал Нга. А люди с тех пор предупреждают детей не разбрасывать волосы, чтобы пауки не сплели сеть. И не убивать паучков, а то Нга сделает их большими. С тех пор люди свои волосы собирают и сжигают, чтобы пауки не сплели большую сеть и не погубили их. Развернутые мифологемы животного мира в произведениях Неркаги глубинны по смыслу и значимости для раскрытия содержания.

В повести «Илир» эмоционально активизирует читателя, кроме уже отмеченных, мифологема собаки. Она гиперболизирует тему борьбы добра и зла в окружающем мире, высвечивает проблему нравственной распущенности и потери человеческого лица в условиях безнаказанности, способствует усилению траге- 
дийности. Пес по кличке Грехами Живущий становится свидетелем проявления человеческой агрессивности по отношению к мальчику-сироте, которого хозяин выселил из чума на «поганую» (оскверненную нарушением правил использования) нарту. Срывая свою злобу на мальчике, желая насладиться унижением сироты, Майма перестал кормить его мясом, бросал лишь кость. Защищая свое достоинство, Илир сначала отказывался подбирать кости, и их с удовольствием обгладывал пес. Когда же Илир совсем ослаб без еды и решил подбирать кости, пес стал угрожающе рычать. «Голодный мальчик и собака стояли друг против друга. Слезы бежали по щекам ребенка, замерзая ледяными дорожками. Но старый пес, прижав уши, не смотрел на него. Он не любил людей. Не любил тех, которые, показывая ласково зубы, гладили по голове, ни тех, что пинали ногами, бросали вслед камни». Больше всего пес ненавидел человеческие глаза, из-за которых становился бессильным, считал, что во взгляде таится гораздо больше зла, чем в руках. Илиру удалось заглянуть псу в глаза и долго не опускать, в ответ тот смирился и стал спокойно реагировать на то, что мальчик брал часть его лакомства. Позднее в благодарность и из сочувствия к больному немощному псу мальчик защищал его от побоев хозяина. Когда же ярость хозяина Маймы по отношению к собаке перешла все пределы, Илир вызвался бегать за оленями, стеречь их вместо пса, чтобы защитить животное от побоев. Хозяин осознавал, что Грехами Живущий не виноват в своей немощи и старости, что когда-то он был псом, равным которому не было в округе, и заменял ему пастухов, чутко улавливал настроение, ему не надо было приказывать дважды, он всегда знал, что от него хотят. Однако воспоминания не смирили гнев Маймы - поселившийся в нем демон не давал покоя его ярости. Ни Грехами Живущий, ни Илир не могли понять нечеловеческой жестокости Маймы. Хозяин все больше свирепел и неистовствовал: согласившись на предложение мальчика помочь собаке, он не только требовал полностью заменить пса во время пастьбы, но стал называть его Грехами Живущим, а потом в порыве злости запретил ему говорить, пригрозив бить за каждое услышанное от мальчика слово. Майма планомерно доводил стойкого, не желающего унижаться и просить сироту в бессловесное покорное ему животное - собаку.

Мифологема собаки в другой повести Неркаги - повести «Анико из рода Ного» - активно участвует в развитии сюжета и способствует созданию образа главного героя Себеруя. Фанта- 
стические диалоги и внутренние монологи человека и животного наполнены в повести экспрессивной оценкой окружающего, действий и поступков героев. Интраверт Себеруй в общении с псом Буро делится раздумьями о необычном поведении своей дочери, рассказывает о глубоко спрятанных сомнениях в прогрессе, наступающем на привычные правила жизни. Буро в описании автора - помощник человека, сильный характер которого формировался постепенно. Будучи щенком, он бросился в драку с большим рыжим псом, который отнимал еду у щенков. Хозяин защитил его и взяв в чум перевязал раны. Далее автор описывает взросление щенка, которое происходило подобно взрослению детей под руководством родителей: «...у него не оставалось времени на щенячьи игры: он все время чему-нибудь учился». Сначала научился по выражению лица хозяина различать, когда нужно лаять, а когда помолчать; наука пасти стадо давалась Буро с трудом, потому что он начинал увлекаться и временами далеко угонял особо строптивых оленей, за что потом получал наказание. Для трудолюбивого пса было удовольствием подбирать убитую дичь, выслеживать зверя. Себерую удалось научить собаку носить на себе мелкие, нетяжелые вещи. Автор подчеркивает чувство эмпатии, понимания и сочувствия людям: «обиды, которая запомнилась бы Буро по сей день не было. Он понимал людей, а люди - его». Верный помощник оленевода погиб в схватке с волком, защищая хозяина, и заслужил оценки, мысленно высказанной молодым оленеводом: «прожил жизнь, какую не всякий человек может прожить». Достойную оценку получил Буро от всех жителей стойбища: тело его положили на священную нарту «в знак особого уважения».

Собака в разных культурах имеет отрицательные, нейтральные и положительные коннотации. В ненецкой культуре наряду с положительными, когда она представлена в роли помощника человека, нередки и отрицательные коннотации. В мифах и сказках-мифах, собранных ненецким художником и этнографом Л. А. Ларом в книге «Мифы и предания ненцев Ямала» ${ }^{4}$, собака предстает животным, созданным верховным божеством Нумом одновременно с человеком. Он отправляет собаку на землю вместе с человеком, чтобы она защищала его. Существуют разные версии мифов о собаке, с помощью которых можно попытаться раскодировать мифологему этого животного. Так, в мифе «Первый человек и собака» сказано: «Когда-то, давно это было, старик Нум в один день сделал человека и собаку. Сказал Великий 
Нум: «Собака, сейчас, с этого дня, этот сделанный мной человек будет твоим хозяином. С человеком хорошо обращайся, всегда охраняй. Пусть не болеет твой хозяин. Всякие такие болезни не пускай к человеку. А я пойду делать небесные дела». Но попав на землю, собака принялась развлекаться и спать, забыла о человеке. Болезни замучили человека. Владелец подземного царства Нга хвалил собаку, радовался тому, что может спокойно забирать у человека дыхание, ощущая себя сильным. Узнав о нерадивости собаки, Нум пнул ее и назвал нерадивой. В мифе «Творец Нум и Нга» творец Нум «в одно солнце ненца и собаку сделал». Собаке наказал: «Я сейчас одежду вам искать пойду. Собака, хорошо охраняй ненца. С этих пор всю твою жизнь твоим хозяином будет. Никого не пускай близко к нему». Не пускала собака к человеку и злого Нга. Тогда старик принес ей теплую малицу (шубу), и за это потребовал слушаться его. Перестала собака охранять человека, и Нга наслал на него болезни. Узнав о предательстве, Нум изменил ее предназначение: «Совсем ты плохая, пользы от тебя совсем нет. Мозги твои заплесневели. С этого дня ненец пусть тебя бьет. Пусть ругает, пусть делает все, что хочет. Пусть использует тебя на самых тяжелых работах. Жить ты будешь на улице. Пусть дождь идет, снег, пурга - всегда будешь на улице. Вот такие мои слова. Как сказал, так и будет. С этого дня ненец будет твоим большим хозяином».

В мифе «Собака - охранник оленей» старик Нум сделал в один день ненца и собаку, оставил ненца на некоторое время на небе, а собаку отправил на землю охранять сделанных им оленей. Но собака предпочитала есть оленей и спать. Увидев через некоторое время печальную картину, Нум рассердился: «Оказывается, ты очень жадная, ни одного олененка не оставила. Сама по себе жить ты не можешь. С этого дня ненец будет твоим большим хозяином. Пусть что хочет, то и делает с тобой, ругает, бьет, мне дела нет. Будешь питаться объедками, оставшимися от пищи человека».

В романах Ледкова мифологема собаки имеет чаще всего нейтральную и отрицательную коннотации. Герои используют ее в сравнениях как для негативной оценки человеческих поступков, так и в качестве символа начала действий, а также для описания традиций в общественном устройстве.

«Ты, Ядна Як, домашний пес: что ты в оленьем деле понимаешь?» - так на собрании председатель колхоза язвительно показал неубедительность мнения героя, предложившего основатель- 
но всем вместе подумать, прежде чем принимать решение об объединении колхозов (роман «Люди Большой Медведицы»). Ирония героя обоснована издревле существовавшим у ненцев своеобразном социальном разделении оленеводов, кочевавших в просторах тундры, и береговых жителей. С оседлостью, и тем более ездой на собаках, у жителей ненецких тундр всегда было связано представление о крайней степени нищеты. По мнению оленеводов, только сильная нужда заставляла человека быть оседлым. Безоленный ненец для тундровиков - «что лодка без весел, что птица без крыльев». Неожиданное появление венодэт — собакооленеводов - бессознательно вызывало у кочевых тундровиков ощущение страха. Этот страх усиливался установкой нового времени - переходить на оседлый образ жизни.

Герой романа Ледкова «Люди Большой Медведицы» оленевод Вавля недоумевает: «Убей, не пойму: что это они про оседлость болтают! Вот ты, Санэ, представляешь, как будет выглядеть этот домашний ненец? На кого он будет похож? Что он станет делать? Может, на собаках будет ездить? Венодэтой станет?»

И как бы в продолжение разговора, для убедительности своих слов Вавля, подойдя к нартам, запел:

\footnotetext{
Наши крылья - оленьи ноги:

И в пургу, и в холода

Эти крылья в любой дороге

Ненца выручат всегда...
}

Собака и олень как символы нижнего и верхнего миров в мифологическом сознании ненцев порой представлены в литературе в сопоставлении: как отрицательная и положительная коннотации. Так, ритуал жертвоприношения духам верхнего и нижнего миров был разделен: традиционно жертвоприношение Нуму белого оленя совершалось в светлое время — весной, а в жертву Нга приносили — собаку в декабре — Месяце Большой Темноты.

В романе Ледкова «Месяц Малой Темноты» герои используют ругательства, выражающие презрение и недовольство: «собачья порода», «собачий сын». Часто звучит пренебрежение по отношению к собакам. Так, во время путины рыбаки в «полуразвалившийся ящик для бросовой рыбы» собирают частично исклеванную чайками рыбу со словами: «Людям не годится, так собаки съедят». Отголоском зооморфных мифов можно считать подобное не самое лучшее отношение героев романа к собакам и владельцам собачьих упряжек. 
Леонид Лапцуй использовал сформированное мифами ироничное отношение к собаке, характеризуя высокий профессионализм оленевода Атены, главного героя рассказа «Палочки с зарубками: «Лишь мужчина, живущий на луне вместе со своей собакой, всю жизнь не может собрать своих оленей-звезд. Атена всегда соберет свое стадо». Речь идет, как уже отмечалось, о темных пятнах на луне, воспринимавшихся силуэтами мужчины и собаки.

Николай Вылка активно использовал мифологему собаки как для эмоционально-оценочной характеристики героев, так и для отражения особенностей социально-общественной жизни. Герой повести Николая Вылки «Марья», чтобы подчеркнуть вынужденность поездки его из родных мест на Новую Землю, иронично сравнивает себя с собакой: «да кто вспомнит собаку, сбежавшую из чума хозяина от побоев».

Для усиления сложности жизни героев в новых условиях автор вводит образ собаки, прибившейся к переселенцам, которую те назвали Плуталкой. По ее натертой шее определили, что она упряжная. Пыя Нырка предположил, что собака могла приплыть на льдине, отстав от поморского судна. Люди оценили стойкость и находчивость собаки и подкармливали ее, однако один из героев Лэхэ, заслышав гром, ударил лежащую в чуме Плуталку и выгнал ее, оправдав свои действия словами: «Что тебе в чуме делать, когда гром гремит?» Как посланница Нга, по мнению героя, именно собака и притянула стихию.

В произведениях ненецких писателей образ собаки разнолик, как и отношение к ним героев. Не менее многолико и порой противоречиво восприятие птицы гагары - то это священная птица, то униженная, достойная жалости, то неприспособленная к созданию семейного гнезда и потому осуждаемая, не дающая хорошего примера людям. Описывая святилище, место поклонения духам и жертвоприношений, Борис Житков в книге «Полуостров Ямал», отметил наличие там деревянных изображений гагар, записал объяснение присутствующих самоедов: «птицы, изображают крылатых духов и посвящены свету, дню» ${ }^{5}$. В повести Николая Вылки «Марья» о переселении десяти человек с Большой Земли, с Большеземельской тундры, с материка на остров Новую Землю в поисках лучшей жизни, убегая от бедности, холода и голода главный герой Пыя Нырка, наблюдая за чайками, отнимающими ракушки у гагар, которые «как побитые собаки, снова ныряют в глубину», сравнивает себя с обиженными птицами, поскольку его также мучил хозяин. Пыя Нырка пытается найти оп- 
равдание несправедливости, смириться с божьей волей: «Видно нас, гаг, создал он для такой жизни». Позднее он находит еще одно сравнение: «Среди гаг чайки - как дети богачей, а гаги плавают, нахохлившись, словно ищут себе тепла и огня».

«А вокруг их чума из-за плохой погоды ничего не видно. Временами где-то в травянистых лужах кричат гагары, словно плакальщицы».

Жена Пыя Нырки замечает: «Вот! К худой погоде как кричат, бедные, видно, болят у гагары косточки, помятые оленем». В сноске автор разъясняет: «Распространенное на Севере поверье о том, что олень наступил на ноги гагаре, и она с тех пор не может ходить».

Николай Вылка сравнивает лодку с водоплавающей птицей: «Лодка, как самец утки-морянки, режет грудью волны. С обеих сторон только вода шипит». Далее он использует зооморфное сравнение плывущих на лодке и только что проснувшихся людей с моржами. «Спавшие, как моржи, приподнялись. Одни потягиваются, другие глаза трут. У Лэхэ, сидящего на корме, усы топорщатся, как у моржа-вожака».

«Вскоре Лэхэ повел свою лодку, как хорошего оленя, к мысу, выдавшемуся в море. Кормчий ко льдам все наклоняется, все топорщит свои усы, как морж на солнце».

Герои повести Николая Вылки наполнены надеждами на лучшее будущее. Их свободная, но сложная жизнь в новых условиях полна радостей и тревог. Привычное общение с одушевленной природой становится для героев еще более тесным и взаимопроникающим. Автор словно предупреждает переселенцев о том, что их ждет безлюдный остров и отправляет вместе с ними в качестве сопровождающих знакомые им природные явления. От берега Югорского шара, пролива у материка, вместе с отъезжающими двинулись на север стихии: подул южный ветер, понеслись слоистые облака, «быстрее мысли» двинулись к северу волны. «Волны величиною с гору подобны запыхавшимся оленям, запряженным в упряжь тюленьих ремней». Одномачтовая лодка, «как самец утки-морянки», то скрывается в ямах между волнами, то выскакивает на гребни. «От движения - на груди ее пена. Скользящие от нее волны уносятся вдаль, как будто их ударил кто-то, и там затевают между собою борьбу. Быстрее мысли, быстрее волн несется лодка. В мачте и снастях ее большой южный ветер поет свои песни. Словно реву каких-то зверей вторит он. От такой песни вдруг и захочется плакать. По обеим 
щекам беззвучно покатятся слезы. Замолкнет певец на миг, и вновь потечет его песня, как мощная быстрина реки». Песни ветра навевают героям воспоминания, из которых читатель узнает о прошлой их жизни, о том, что послужило причиной отъезда из родных мест на «безвестную землю».

Главный герой повести Пыя Нырка не только правит лодкой, но внимательно следит за жизнью птиц, сравнивает их поведение с человеческим. Так, чайки кричат «словно бранчливые женщины» и напоминают герою бывшую хозяйку, у которой работал: «Прежде моя хозяйка, как вы, без толку бранилась». Чайки агрессивны, отнимают у гаг принесенные ими ракушки. Завидев выныривающую с ракушкой гагу, чайка с криком набрасывается на нее. С этой беспомощной птицей и сравнивает себя герой, поскольку и у него хозяин отнял почти всех оленей в уплату за потерявшихся или заболевших из общего стада, которое он пас.

Чайка, по-ненецки халэв, в мифологии народа является священной птицей. Нум, согласно мифу-сказке, внимательно рассмотрев сделанную хозяином семи ветров птичку, приказал всем: «Никто не должен трогать, убивать халэв. Кто убьет, тот будет наказан. Пусть с этих пор халэв вызывает хозяина семи ветров и насылает сильные ветры на людей, которые обидели его». Тот, осознав свою вину в гибели многих людей, решил в помощь себе и людям создать птичку, которая бы предупреждала людей о прибытии ветра и показывала его направление. Вдохнув в птичку жизнь после одобрения своего творения Нумом, хозяин ветров вынес ее на улицу и сказал: «Люди на реке ловят себе рыбу. Будешь летать над речкой и показывать им направление ветра, люди за это будут кормить тебя рыбой. Однажды рыбак не дал халэву рыбы, и обиженный халэв полетел жаловаться навстречу ветру. Хозяин семи ветров наказал обидчика за неуважение к его творению. Когда халэв летит против ветра, значит ждать беды. Поэтому рыбаки никогда не трогают халэв. Стараются накормить птицу рыбой, чтоб был хороший улов. В романе-дилогии В. Ледкова «Люди Большой Медведицы» (вторая часть дилогии) рыбаки во время путины наблюдают за поведением чаек и узнают, где больше рыбы, бросают им на корм рыбу, а когда чайки пытаются клевать рыбу на вешалах, прогоняют, но не ругают их, а называют их «остроглазыми птицами».

В повести Николая Вылки «Марья» представлена картина, свидетельствующая о существующем и в мире животных «социальном» устройстве, которое нельзя, по мнению героев, назвать 
справедливым: «Ветер стал стихать, и чайки сели на воду. Среди гаг чайки - как дети богачей, а гаги плавают, нахохлившись, словно ищут себе тепла и огня». Главный герой Пыя Нырка сравнивает себя и свою судьбу с мучениями гагары неслучайно.

Гагара в ненецких мифах и сказках - превращенный в птицу человек. В одном из мифов о создании Нумом земли сказано, что Верховное небесное божество сделал для своего развлечения человека, но не знал, где его поселить. Решил Нум создать для него землю и стал искать способ, как достать ее из воды. Превратил он первого человека в гагару и приказал спуститься под воду, принести немного земли, которую пообещал превратить в большую землю. Прилетев на середину моря, гагара стала нырять и через каждые семь дней приносить сначала песок, потом ил, а на третий раз - кусочек земли. Нум все соединил и бросил на воду, а сам пошел отдыхать в свой небесный чум, забыв про гагару. Долго ждала она Нума, а потом заплакала горькими слезами, свила себе гнездышко рядом с водой. Снесла яйца, но одно из них бросила хозяину воды в знак благодарности, что разрешил вынести на свет землю. Бросив яйцо, она стала жалеть невылупившегося птенца и снова стала плакать». С тех пор гагара приносит в жертву хозяину воды одно яйцо. И каждый раз оплакивает своего невылупившегося птенца. «Поэтому мы часто слышим горькие крики гагары», - утверждают ненцы.

В другом мифе-сказке в гагару превратился рыбак, который, услышав шум, вышел из любопытства узнать причину и был подмят несущимся стадом оленей. Он подполз к воде в стонах и опустил ноги, а потом и руки в воду. Боль утихла, но ноги превратились в лапки, а руки - в крылья. Заплакал он горькими слезами. Пришла на берег жена, но в птице мужа не признала. « $\mathrm{C}$ тех пор гагары плачут и стонут от боли и оттого, что потеряли свой человеческий облик».

Василий Ледков в «Месяце Малой Темноты» не раз использует плач гагары для того, чтобы подчеркнуть горести и безвыходность положения героев, выразить их отношение к поведению других людей. Так, пастух Егор Явтысый, замученный непосильным трудом и жестокостью хозяина, утром слышит «по-женски горькое рыдание гагары», настолько горькое, что ему тоже хочется заплакать. Героиня Саване, наблюдая за гагарой, отмечает сначала странное ее поведение: «Изогнув дугой шею, она не ныряла и не уплывала от берега, а как-то забавно кряхтела. Стараясь вспугнуть птицу, Саване покрикивала на нее и гремела пустыми 
ведрами. Гагара казалась бесстрашной: она только вытягивала шею и медленно повернула в сторону Саване свою ширококлювую голову». Наклонившись, женщина поняла: птица защищает два «продолговатых, с темными крапинками “яйца". У самого берега вынырнула гагара и скорбно, почти по-человечьи зарыдала». Для Саване, мечтавшей о детях и не имеющей их, картина защиты гагарой своего потомства стала своеобразным потрясением. Она вспомнила то, как однажды ее муж Одерма, увидев на воде двух гагар, которые то ныряли, то всплывали, «играли свадьбу», выстрелил из винтовки и просто «чтобы глаза и руки от винтовки не отвыкли», убил одну из них. Эта всплывшая в ее сознании картина словно высветила жестокость, бесчеловечность ее мужа, с которым она жила по воле родителей, была выдана за него вопреки ее воле, поскольку любила другого мужчину. Она даже как бы увидела возможное наказание Одерме за его бездумное убийство гагары. Однако в ожидании долго не возвращающегося мужа женщина плачет не сдерживаясь, «напоминая рыдающую над озером гагару», сравнивает себя с этой одинокой птицей и завидует ей, поскольку у той «вот-вот будут дети».

Мифологические представления ненцев о происхождении гагары вошли в структуру сказки «Девушка и гагара», стали основой ее сюжета. За девушкой, любившей сидеть на берегу озера, внимательно наблюдала и очень близко подплывала к ней большая черногрудая гагара. Однажды девушка сняла пояс, сделала из него силок, чтобы поймать гагару, и спряталась в кустарнике. Но гагара схватила пояс и улетела. Весной птица вернулась, перевязанная поясом девушки, и вновь стала подплывать к ней, а иногда и прилетать к чуму. В конце лета птица вышла на берег и превратилась в красивого парня-богатыря в богатой одежде с ее поясом. Он предложил ей пожениться. «Говорят, молодой муж хорошим рыбаком и охотником стал. И теперь у него много оленей. Всем он выделялся: и силой богатырской, и красотой особенной, и старанием в делах. Долго и счастливо жили они с женой - красавицей и мастерицей, много детей имели, а потом и внуков» (сказка записана и пересказана ненецким поэтом и прозаиком Любовью Ненянг $^{6}$. Сказка несет в себе следы сохранившихся в ней и у героев Ледкова мифологических представлений о превращении первого человека в гагару, которая помогла Нуму создать землю).

Анна Неркаги в повести «Белый ягель» дискурсивно вставляет в текст более древний, еще не связанный с Нумом, миф о происхождении плача гагары. Автор при поддержке мифа развивает 
мотив проблемной, наполненной драматизмом подготовки к завершению жизненного пути, заостряя вопрос об ответственности детей за своих родителей. Двое пожилых оленеводов ведут беседу о трудностях, связанных с одиночеством и ослаблением жизненных сил в старости. Рассказанный миф о гагаре наводит героев на глубокие раздумья и важные решения. Миф погружает во времена, когда «все живое подчинялось одному закону - закону солнца». На берегу озера жила семья гагары. Отец - гагара имел много оленей, и дети привыкли жить в праздности, дрались около растерзанной туши оленя, которого вечером после захода солнца приводил отец, царапали лицо матери, не разрешая подходить к туше, пока они не насытятся. Солнце не видело их проделок, но однажды последний лучик оглянулся и увидел злобные пиры. Рассерженное солнце наказало гагар, затопив жаром их землю. С тех пор от страха перед солнцем и плачут на берегу гагары. Рассказчик произносит резюме, перенося происходившее на людей: «Прошлое темно, и кто знает - в давней давности, может, и человек не признавал законов труда и добра, и жил гагарой и его манит к себе темное кровавое прошлое. Тоска заливает душу, и он плачет на берегу жизни совсем как гагара». Выслушав миф из уст друга, осиротевший Пэтко, которого забыли дочери, убеждает, что его плач никогда не будет плачем гагары. А друг Вану молча размышляет о птицах, в судьбах которых можно человеку найти примеры как для отрицания, так и для подражания. Его радует, что птицы ранней весной возвращаются в оставленные гнезда, он приходит к жизненно важному заключению: «...не будет на земле птичьих гнезд, этих маленьких святынь, не станет и человеческих. И не кто-нибудь, а именно человек в ответе за судьбы больших и маленьких гнезд, и своих, и птичьих».

Создавая образ Саване, сильной духом, размышляющей о своей жизни, руководствующейся установкой «Надо бороться за свое счастье», решительной женщины, В. Ледков в романе «Месяц Малой Темноты» привлекает зоонимы, сопоставляя поведение женщины с поведением животных, устанавливает связь метафорического порядка, приоткрывая завесу над взаимодействием и взаимовлиянием человека и животных.

Тревогу героини романа Саване из-за вынужденного отъезда мужа в поселок в сопровождении милиционеров для беседы о его нежелании отдать оленей в колхоз, из-за его длительного невозвращения автор усиливает описанием встречи женщины с гагарой. Птица вела себя странно: «Изогнув дугой шею, она не 
ныряла и не уплывала от берега, а как-то забавно кряхтела». Саване пыталась отогнать ее покрикиваниями, чтобы набрать воду, но птица не улетала. Она вела себя бесстрашно: вытянув шею, медленно повернув в сторону Саване свою «шилоклювую голову», стала угрожать женщине. Когда же Саване, увидев два яйца, стала рассматривать их, гагара «скорбно, почти по-человечески зарыдала».

Смелость и решительность птицы в защите своего будущего потомства порадовала героиню, и вместе с тем усугубила страдания по поводу отсутствия у нее детей, поскольку выдали ее замуж за пожилого, но богатого «хозяина Малой Тундры». Беззащитность птицы перед волей человека вызвала воспоминания женщины о пострадавших из-за жестокости ее мужа двух гагарах, которыми она однажды восхитилась, увидев на глади озера «играющих свадьбу». Но бывший не в духе, привыкший к власти муж Одерма, услышав несоответствующие его настроению слова, схватил винтовку и выстрелом «будто расколол землю надвое». И объяснил свой поступок словами «Я им показал свадьбу!» В ответ на ее укор, зачем он это сделал, сказал: «Чтобы глаза и руки от винтовки не отвыкли...» Перед женщиной неожиданно предстал человек, которому «ничего живое было недорого». Она вспомнила, как ощущала себя вольной птицей в чуме родителей, но подчинилась их воле. К ней пришло запоздалое горестное осознание: «продали ее родители, как ненужную важенку, променяли на оленей и песцов».

«Уже не сдерживаясь, Саване плакала, напоминая рыдающую над озером гагару. Она сравнивала себя с этой одинокой птицей и в то же время завидовала ей: у той вот-вот будут дети».

Гагара в произведениях Ледкова выступает в основном как птица печали, птица, скорбящая о прошлом или настоящем.

Семантика образов животного мира расширена ненецкими поэтами и прозаиками благодаря самому важному компоненту - индивидуально-личностному, отражающему мифологическое авторское понимание образов. При этом предполагается, что в роли мифа выступает не только мифология в узком смысле, но и исторические предания, бытовая мифология, фольклор.

В повести Анны Неркаги «Белый ягель» оленеводы старшего поколения Вану и Пэтко постоянно в мыслях и беседах уподобляют птицам своих детей, оставивших их. Вано задумывается, почему его сыновья, «приезжающие летом, кажутся больными странной, птичьей болезнью: крылья есть, оперение целое, а ле- 
тать не могут». Полет же сыновей ассоциирует герой с умением их владеть мастерством оленевода, способностью выживать в условиях тундры. Даже простейшие действия - собирать и бросать ловко аркан, работать топором - им недоступны: «Берёт сын в руки аркан, а толком ни собрать, ни бросить не может. Топор возьмёт - сразу отберёшь, кажется, вместо дерева он возьмёт и оттяпает себе обе ноги».

Используя зооморфизмы, сопоставляя отношение птиц к своим гнездам с умением людей строить «гнездо любви», Неркаги раскрывает драму в семье молодого оленевода, в которой мать определила для сына невесту, чтобы продолжить род, а он не может забыть свою первую возлюбленную, продолжает ждать ее, не принимая избранницу матери, живущую в его чуме. Имплицитный автор-рассказчик размышляет о том, что в отличие от птиц, которые, прилетая на родное озеро, сразу же заботливо начинают вить гнёздышко, люди делают «гнездо любви», не заботясь о самой любви: «мол, вытерпит, живуча», строят «мрачно и непрочно», «торопливо, жадно, порой постыдно». И такое отношение к любви гонит прочь ее «прекрасную душу», «остается лишь “тощий скелет”». Обиженная отношением сына к живущей в чуме девушке мать героя мысленно обращается к нему, предлагая задуматься над поведением птиц, взять с них пример: «Почему бы людям не поучиться делать гнёзда любви у птиц небесных? Птичка-женщина всю себя общиплет, лучшие и тёплые пёрышки у себя пообрывает и лишь потом избранника позовёт для любви. Хотя и среди птиц есть дурные, например, гагара. Кочку моховую полохматит, ямку в ней наскоро потопчет - вот и всё гнездо. А потом у озера горько плачет, если ветер разнёс её нехитрое жильё, если муж гагара клюнет её в злобе, если хищник разроет незащищённую хитростью кочку».

Свой обряд подготовки брачной постели для сына героиня сопровождает заклинанием, в котором активно участвуют зоонимы:

«Пусть не гагарьим гнездом сделают руки и сердце постель сына. Пусть верность орла и нежность белой лебеди поселятся в нем. Злой ветер зависти не развеет, и падальный ворон не прилетит, счастье сына не расклюёт. Чтоб не плакал сын одинокой гагарой, когда наступит осень жизни».

Заклинания с использованием зоонимов были традиционны у ненцев. Ими пользовались не только женщины, но и мужчины, собираясь на охоту или рыбную ловлю, на морской зверобойный промысел, что нашло отражение и в фольклоре, и в литературе. 
Ненецкие поэты и прозаики сохранили в своих произведениях отблеск мифической слитности фантазии и реальности. Бессознательно опираясь на закон мифологического творчества - закон имагинации (воображения), многопланового и синкретичного по своей природе, посему не поддающегося точному определению, они создавали и создают имагинативное бытие, имагинативные миры в своих произведениях, соединяя идеальное и реальное, внешнее и внутреннее. Этому синтезу нередко способствует обращение творцов к сновидениям и фантазиям с использованием образов животного мира.

Лапцуй в стихотворении «Сон у костра» представляет мир глазами и чувствами лирического героя, вспоминающего детство в картинах сна около «родового» костра, где он уснул «тюленьим крепким сном». Символический зооморфный мир наполняет картину сна: он «по темным небесам, словно белый гусь» летит и, держа в руках хорей, «будто бы оленей» гонит по тундре песцов; радуется и смеется («хохочет») словно «чайка сизая весной». Герой связывает полет в детстве с приметой - если ребенку снятся птицы, то следовательно он в это время растет. Вероятно, эта примета о росте возникла с неосознанным пожеланием ребенку приобщаться к миру недоступных человеку возможностей птиц и зверей, надеждой на то, что они разгадают их тайны.

У Вэллы во сне Талё-Охотник видит себя Белым олененком, бегущим по краю теплого песчаного озера, «будто перед ним солнце расстилается разноцветной радугой и сквозь эту радугу улыбается ему навстречу Мать-олениха». Образ Матери-оленихи в сновидении, с одной стороны, антропологизирован: «она расчесывала костяным гребнем мокрые, только что вымытые прозрачные волосы»: а с другой - сакрализован, определен в роли символа земли: «Озеро отражалось не только в ее счастливых глазах, но и в каждой капле воды на ее теле. Словно она сама была уже не только озером, а безграничным, огромным, совершенным миром...» (Ю. Вэлла. «Из сказки Бабушки-Ненги»).

Как уже отмечалось, нередко в произведениях ненцев, как и у других писателей народов Севера, мир жизни животных представлен в виде социальных связей, таких, какие преобладают в человеческом обществе, например, сходство и различие между видами животных представляется в описании дружественности и конфликта, солидарности и противоположения.

В. Ледков в романе «Месяц Малой Темноты» сравнил ситуации с развитием отношений в птичьем мире с коллизиями из че- 
ловеческой жизни. Он описывает раздумья героя о несправедливости в организации человеческого социума, о жестокости одних, безвыходности у других, об отсутствии у сильных сострадания и сочувствия слабым. Эти ассоциации возникли после того, как к его ногам в поисках защиты опустилась куропатка. Искать спасения у человека, стать бесстрашной ее вынудили два ястреба. Герой наблюдает, как в поисках добычи стервятники стали низко кружить над мечущимся маленьким жаворонком, прижимая к земле. Слетевшись на мгновение над жаворонком, они взмыли вверх и полетели в сторону моря. «Жаворонка в небе уже не было. Степан следил за ястребами, тающими в синеве. Сам того не замечая, он яростно сжимал кулаки: вот так и среди людей...» Прячущаяся около него куропатка — «краснобровая красавица» уткнула головку под ветку карликовой березы, Степан взял это трепещущее существо в руки. Перед тем, как отпустить ее, он исполнил обряд: «осторожно выщипнул крохотное перышко и втер его в свои волосы: теперь можно отпустить ее птица не унесет с собой человеческого счастья. Степан погладил куропатку, поцеловал головку и, вытянув руку, раскрыл ладонь. Куропатка благодарно блеснула круглыми глазками, оглядела небо, расправила красные брови и взлетела. А Степан все еще стоял с широко раскрытой ладонью...»

Куропатки и совы - спутники ненца в долгую зимнюю полярную ночь - наделены в мифах и сказках особыми психолого-физиологическими характеристиками за свое нехарактерное для остальных, улетающих в более теплые края птиц, стоическое выживание в условиях снежных бурь, бескрайней пустынной тундры. Согласно этиологическому мифу «Куропатка», птица осталась зимовать в тундре из-за обмана хищницы-совы. Хитроумная сова охладила желание куропатки лететь вслед за гусями в теплые края: «Вон там отверстие в солнце, они сквозь него полетят. А оно горячее будет. Оно узкое будет. Они-то пролезут. А мы с тобой ведь не пролезем. Там застрянем и сгорим». От услышанного куропатка заплакала, глаза ее стали красными. В лесу оставшейся куропатке угрожали разные звери: песец, лиса, волк и даже медведь, но ей удалось уцелеть, убегая на своих тоненьких ножках. Устав от угроз, птица «садясь на кочку, закричала по-куропачьи: На берегу моря, оказывается, житья нет! В лесу житья нет! Придется мне жить в тундре вместе с совой».

Странные птицы зимы - куропатки в воображении Алексея Пичкова «Над землей куропачья стая...» становятся символом 
робких, неясных, зарождающихся чувств у лирического героя стихотворения.

Над землей куропачья стая

Белым облаком пролетает.

Белым облаком, белым дымом...

Только встретимся, слова не скажем,

На прощанье друг другу машем.

Друг для друга в тумане таем

Куропачьей белою стаей...

В описании начала зимы у А. Пичкова в стихотворении «Закружился белый листопад...» куропатки, меняющие серое оперение на белое, становятся объектом для сравнения. Первый снег уподоблен птицам: «Куропатки в ивняках стрекочут, // Куропатки над землей летят».

В поэзии Пичкова куропатки постоянно ассоциируются с полуостровом Канин, поскольку он родился в семье оленевода на этом полуострове, с сопок которого видны два моря - Белое и Баренцево. Вплетая в ткань стихов свои личные впечатления о родном крае и его природе, животном мире, поэт постоянно обращается к мифологеме куропатки. Изобилие куропаток на полуострове послужило источником для образного определения края, он назвал родной край «куропачьей державой»: «Ты уедешь на Канин // Куропачью державу». Лирический герой стихотворения Пичкова «Дорога», исполненный тоски о близких и знакомых ему с детства, но исчезнувших кочевых стойбищах, радуется встрече с неизменными жителями полуострова - птицами: «Куропатки в воздухе вечернем. // Лебеденок мечется вдали. // Не найти старинного кочевья:// Все они осокой поросли».

Стихотворение «Полярная сова» Василия Ледкова проникнуто сочувствием человека к зимующей вместе с ним птице. Безрадостна картина ее зимовья: «в белом совике (совик - верхняя меховая одежда) / Сонная сова, //С виду — чуть жива, // Словно камень белый, // Весь обледенелый». Автор акцентирует внимание на том, что сова, чтобы сохранить тепло и силы, сидит не шелохнувшись.

В поэзии нашло отражение ироничное отношение к "хохоту» куропаток в брачный период. Используя иронию и сравнение, Лапцуй осуждает легковесных людей: «Голова твоя пустая / так и вертится по ветру / и хохочет во все горло, / словно в тундре куропатка / в брачный ветреный период». 
Для отражения ироничного отношения героев к происходящему использует Ледков зоонимы чайки и вороны в романе «Месяц Малой Темноты»: «Заклевали меня, Роман, бескрылые чайки», - жалуется богач Тэси на преследование со стороны желающих раскулачить его.

«Ворона лебедю не пара» - объясняет отказ жениху своей дочери пастух Варук Вась, герой романа Ледкова. Претендент на руку дочери пастуха - сын богача Тэси, горделивого, стремящегося стать хозяином тундры. Ситуация осложнена тем, что Варук Вась украл и спрятал часть принадлежащего хозяину стада и не хочет быть разоблаченным в случае замужества дочери. Став хитрецом и обманщиком, Варук Вась невольно сравнивает себя с вороном. Отождествление могло быть вызвано бытовавшим у ненцев предубеждением: ворон хитер и коварен. Так, в этиологическом мифе-сказке «Почему рыбы живут в воде?» ворон обещает детям-рыбкам вылечить их больную мать, потом удаляет их из чума. Предупреждает, чтобы они не возвращались в чум даже тогда, когда их мать будет звать. Послушные дети долго ждали и не отозвались на крики матери. Ворон же в это время оставил лишь одни косточки от нее. Обманутые и обиженные дети рыбки, спасая свою жизнь, стали с тех пор жить в воде. Но они отомстили коварному ворону: нагнав хвостами волну, утопили его.

Эстетический и нравственный идеал для ненцев среди птиц - лебеди. Об этом свидетельствуют поэты, воспевающие красоту и верность лебедей в своих стихах - «Белая лебедь» Василия Ледкова, «Белые клики» Юрия Вэллы, «Лебедь белая» Прокопия Явтысыя. Лирический герой стихотворения Явтысыя встревожен «печальным кликом» и мечущейся над рекой Нерутой птицей, зовущей потерянного лебедя - супруга. Услышав неожиданно в качестве ответного зова хоркание оленя, птица унеслась к нему. Неизвестность судьбы лебединой пары не дает покоя герою, и он по утрам ходит к реке Неруте.

Лебедь издревле символизирует всемогущество любви. Он полновластно царит в воде, на земле, в воздухе. Античные писатели упоминают лебедя как священную птицу Афродиты.

В стихотворении Василия Ледкова «Белая лебедь» сцена любования героя красотой птицы, ее величественностью нарушается выстрелом. Это злодеяние подверглось остракизму как со стороны людей, так и птиц:

...ночью в чумах старики седые

Убийцу словом песенным судили. 
И криком, полным страсти и печали

Им лебеди из тундры отвечали.

Единение человека с природой, животным миром, взаимопонимание и взаимоподдержка внутри животного мира издревле заложены ненецкими мифами и сказками. Лебеди, согласно «Легенде о женихах» в литературной обработке Прокопия Явтысыя, тесно связаны со стихиями и с Космосом: «Давно это было, когда ещё Ветер с Луной на Савдейских сопках чай пили, а лебеди им воду в чайниках приносили». У ненцев лебеди пользуются особой любовью и традиционно находятся под защитой человека. Алексей Пичков знакомит нас с поверьем «Где-то на озерах лебедь ранен, // Оттого кровавится закат». Лирический герой его стихотворения «Я хотел бы солнце заарканить...», представив, что птица ранена, готов отдать «дыхание свое», т. е. готов отдать душу, которую ненцы связывают с дыханием.

Птицы ненецкими поэтами нередко воспринимаются как воплощение человеческой души. Это аллегория полета мысли, фантазии, воображения, знак свободы и раскрепощения.

Символическим аналогом души становится белый лебедь в стихотворении Явтысыя «Гнев». От гнева, рожденного в груди лирического героя, «душа с печальным стоном /белым лебедем взлетела, /чтобы в черной буре гнева /свои крылья не сломать». И только когда герою удалось разумом остановить «вспышки молний», «ярость слов», «лебедь белая вернулась».

Вспоминая любимую девушку, лирический герой в стихотворении Пичкова «Далеко Сэрне моя живет...» обращается к природе, привлекает лебедя и необычную красноперую рыбу, чтобы через красоту природы ее края подчеркнуть красоту избранницы:

Далеко Сэрне моя живет,

Там, где месяц лебедем плывет,

Там, где зорька рыбой красноперой

Плавает и плещется в озерах.

В стихотворении «Ивовое море» В. Ледкова радость весеннего пробуждения природы связана с полетом, ассоциируется с лебединой песней:

И песня, расправив сильные плечи,

Умчится в полет,

Легка и светла.

И звезды заденут,

И небо расплещут

Ее лебединые два крыла. 
О метаморфозах, происходивших в нравственных установках охотников, пишет Юрий Вэлла в «Белых криках». Это поэтическая история об охоте на белых лебедей в прошлом и варварском истреблении в настоящем. Когда-то дед лирического героя «слыл добычливым охотником» и обеспечивал людей своего рода теплой лебяжьей одеждой и в голодные годы - лебяжьим мясом. Охота, оправданная жизненной необходимостью выживания, была ограничена правилами, потребностями людей, что не вело к бездумному истреблению птичьего рода. Охотник следующего поколения уже убивал лебедей для продажи шкурок приезжим людям, тратил деньги чаще всего для приобретения спиртного, разрушающего здоровье, сокращающего жизнь. Он «яростно расстреливал белые крики». И «почему-то никто никогда не называл его удачливым охотником». Поэт спрашивает представителя нового поколения, которому подарили ружье: «На кого ты его нацелишь?»

В рассказе Айваседы «У заброшенных гнездовий» герой, впервые приехавший в лесотундру по приглашению молодого ненца городской житель Саня, взглядом новичка наблюдает жизнь птиц на берегу удаленного от жилья озера. Его восхищает забота пары величественных орланов-белохвостов о своем птенце. Автор делится с читателем знаниями об орлане, сакральной, сильной птице, способной защитить от нападок не только свое гнездо, но и гнезда других более мелких птиц. «Под орлиным гнездом на соседних кустах, березках, сосенках, на кочках, под выворотнями, под валежинами, прямо в траве, на некотором расстоянии от берега и совсем у воды было множество различных по величине и по форме птичьих жилищ. И не случайно мелкие птахи выбрали себе гнездовье здесь. Когда орланы, защищая своего птенца, нападают на своего врага, приблизившегося к гнезду, этим самым они защищают все птичье гнездовье». Гостя тундры Саню поразила неожиданная многоголосая песня журавлей: «Вдруг, он даже вздрогнул от неожиданности, где-то рядом, на соседней болотине, громко, звучно, словно торжествуя, затрубил журавль. Песнь его еще не кончилась - ее подхватил откуда-то второй, третий. И уже в следующий миг невозможно было определить, сколько их участвовало в оркестре. Великая птичья мелодия поднималась все выше и выше, разносилась по широкому простору лесотундры, затопляя собой дальние ее уголки. И в какое-то мгновение было не различить, то ли журавли еще трубили, то ли уже эхо отзывалось». 
Звуки песни оборвались так же внезапно, как и начались. Вокруг стало тихо-тихо, словно мир был оглушен. И в этой тишине, блеснув последний раз по молодой листве, по лазурной траве, по теперь уже не белым, а огненным цветам кривой рябины, погас последний луч уплывшего за горизонт солнца. Музыка, дополненная светом! Световая гамма на закате солнца, дополненная звуковой гаммой птичьих голосов заворожила Саню. Картины организованного журавлями провожания солнца на ночлег и заботы орлана глубоко запали в душу героя. Он принял решение приехать сюда на следующий год вместе с семьей. Каково же было удивление, когда через год уже не было слышно журавлей, а гнездо орлана было полуразрушено - слышен был лишь шум моторов на противоположном берегу озера, где уже стояла нефтяная вышка. Предстала грустная картина нарушенного миропорядка в природе.

Орлан, орел в мифологии ненцев - носитель счастья. Он возрождает природу, благодаря его сакральной силе возвращаются весна и тепло, поэтому в календаре ненцев апрель назван «месяцем орла».

Могущество орла, способного уносить в когтях крупную добычу, сила полета, дающая ему возможность подняться выше других птиц, и следовательно, близость к солнцу, необычный взгляд, словно мечущий молнии, издревле выделяли птицу и способствовали ее сакрализации в мифологиях многих народов земли. Л. Я. Штернберг предполагал, что в глазах первобытного человека эту птицу превращала в благодетельное существо и покровителя еще и отличительная особенность её - неагрессивность по отношению к человеку.

Величественная птица-орел в повести Неркаги «Молчащий» предстает защитницей и властительницей пернатых. Орел покидает живой мир во время наступившего апокалипсиса последним, как капитан корабля. Автор наделяет орла особыми способностями - силой, умом, ответственностью за сохранность жизни на земле. Она называет его Хозяином неба. Три года ищет одинокий обессиленный орел птиц в небе или животных на земле родного края, но видит лишь груды костей и облысевшую, израненную землю. Потеря духовного единства с природой привела к физическому и нравственному краху вымышленного народа - скопийцев, - они уподобились в повести кротам. Образ гордой величественной птицы - символа мощи усиливает трагизм событий, происходящих в повести. 
Охота на птиц и других представителей животного мира осуществлялась с соблюдением определенных установок и ритуалов, с помощью которых ненец стремился оправдать свое кровопролитие. Испытывая неловкость за то, что приходится убивать морских зверей, возвращаясь с морской охоты оленевод Пета («Люди Большой Медведицы») пытается в песне скрыть за иронией и шуткой свое чувство, с одной стороны, а с другой, надеется, что его песню услышат звери и простят его за жестокость. В песне охотника слышится как безобидная насмешка над морским зверем, так и запоздалое сочувствие его беззащитности:

\section{Ползет на ледяной простор \\ Морской безрогий хор ${ }^{7}$. \\ Он от рожденья неуклюж, Ленив и глуп к тому ж.}

В стихотворении «Пожелай мне, товарищ, удачи» Пичков обыгрывает заимствованное из русской традиции пожелание «ни пуха, ни пера», превращая его в значение с отрицанием. Приехавший в тундру на охоту лирический герой «забывает ружье», бродит по тундре и любуется гусиной стаей, улетающей в чужие края. Его радуют остающиеся на зиму куропатки: «Разговором шальным куропачьим // Просыпается утром яра» ${ }^{8}$. Забытое ружье представлено автором как знак проявления человечности к птичьему миру.

Главный герой романа «Месяц Малой Темноты» Пета вспоминает детство, когда он «совершал свои вылазки на песцовые урожаи, на заячьи пастбища», собирал с ребятами куропачьи яйца «во время весеннего гнездованья». При этом он подчеркивает впитанное с молоком матери правило, которое дети неизменно соблюдали: «берут у птиц только половину, оставляя остальное на развод».

Словно вторя Ледкову, в своих стихах Явтысый напоминает будущим поколениям совет, полученный в детстве и помогающий не стать «посланцами птичьей беды»: «Если яйца берешь из гнезда для еды, то гнездо не должно оставаться пустым».

В поэзии отражено доброжелательное отношение ненцев к молодой поросли зверей, которое уподобляется заботе о детях. Так, герой Пичкова в стихотворении «Дочь охотника» переносит свои чувства к только что родившейся дочери на лисенка, попавшего в капкан, и выпускает его на волю, не боясь насмешек и упреков сородичей в том, что вернулся без добычи. Охотник мо- 
делирует проявление радости зверька: «Он летит одуревший от счастья, // Скоро будет в лисьем дому».

Пребывая в силу кочевой жизни или во время охоты наедине с природой, ненцы, как и другие народы Севера, ведут не только внутренний монолог с собой и обращаются к представителям окружающей флоры и фауны, но и вступают в диалог, получая порой ответы в виде звуков и действий. Это общение с животными можно объяснить как мифологической сопричастностью (по Брюлю), так и тем, что животные обладают практическим воображением и интеллектом (по Кассиреру). В работе «Опыт о человеке» Эрнст Кассирер выражает согласие с биологом Иоганном Икскюлем, что у животных, особенно высокоорганизованных, есть способность «решать довольно трудные проблемы и что эти решения нельзя получить чисто механическим путем проб и ошибок» ${ }^{9}$. Он считает возможным сделать вывод, что животное обладает практическим воображением и интеллектом. Тогда как у человека развилась новая форма - «символическое воображение и интеллект» ${ }^{10}$. Однако, по его мнению, животные не могут развиваться, поскольку лишены бесценной и необходимой помощницы - человеческой речи, системы символов.

В поэзии и прозе ненцев в словах и поступках героев часто проявляется умение понимать язык птиц и зверей. Лирический герой стихотворения Пичкова «Бьет кустарник рыжий по щеке...», шагая по неизведанному пути, устремленный к покорению стихии, словно «слышит» в птичьем щебетании разговор о дожде: «Мне понятны птичьи разговоры: // Я и сам мечтаю о дожде». Способность героя не придумана и не мистическая ненцы на основе длительных наблюдений выработали умение распознавать по птичьим голосам их «разговоры», которые в быту всех народов именуются порой приметами.

Для предсказания погоды и определения, соответственно, своих будущих действий, ненцы использовали нередко как издаваемые звуки - песни птиц, так и их внешний вид в тот или иной момент и даже внутренности (кости, хрящи и др.). Герои романа Ледкова «Люди Большой Медведицы», беседуя о погоде, отмечают:

«Лето будет жарким. Чирок про то сказывает: видели небось: грудная кость у него, как стекло. Правда, есть небольшие тени - значит, к концу лета тучи сгустятся. тий.

- Грудная кость у чирка иногда врет, - не согласился Игна- 
- Это-то да... - не стал спорить с ним Пета. - Молодая птица - одно, старая - другое. У прошлогоднего выводка кость всегда потемнее: хрящ еще не совсем окостенел. Для оленевода жаркое лето - беда. Для рыбака - счастье. Я не всем приметам верю. Вон сейчас у каждой рыбы пузырь до отказа надут. А ведь говорят, к штормам это.

- Бывалые люди так говорят - к штормам, - подтвердил Митро. - Не прав ты, в каждой примете есть какая-то истина, тут уж ничего не скажешь. Ведь люди это жизнью проверили...»

Беседа героев - убедительное свидетельство наличия у ненцев «бытового барометра» - примет, основанных как на собственном опыте, так и на опыте предков. Мифы и легенды, этиологические сказки, а также развитая наблюдательность за жизнью животных послужили основой для умелых (точных) предсказаний погоды.

В число высокоорганизованных представителей животного мира ненцы относят, в первую очередь, оленей, а также волков и медведей.

«Олень для ненца - илебц, жизнь» - эти слова Ледкова в романе «Месяц Малой Темноты» можно назвать определяющими в описании жизненного уклада героев его романов. Своеобразно единение героев с оленем, которого, кстати, многие ученые относят к высшему виду мыслящих животных. Олень предстает как животное, имеющее способность мыслить и вступать с человеком в диалог, поддержать его в сложной ситуации. Олени отличаются разным характером, разными способностями и возможностями. Некоторые из них воспринимаются как сакральные животные. Так, пестрые и белые олени, по мнению ненцев, обладают особой магической силой. Пестрые олени - символ разнообразия жизни и перемен. «Весна в тундру на пегом олене приехала!» - шутят герои романа Ледкова «Люди Большой Медведицы», радуясь приходу бурной ранней весны. Существовали олени, посвященные Нуму, солнцу, огню. Обычно это были олени белой масти, на их боках выстригали знак солнца или изображали духов. Таких оленей не впрягали в нарты, не убивали. Уши и рога их украшали красными ровдужьими лентами. Когда такой олень погибал, то вместо него посвящали другого белого оленя.

Зооантропологический образ матери-оленихи предстает во сне Талё-Охотника в стихотворении Вэллы «Из сказки БабушкиНенги» в виде женщины-матери. Себя же охотник видит белым олененком, бегущим по песчаному берегу озера. Мать-олениха, 
расставив крепкие ноги и вонзив черные, словно лакированные, копыта в белый песок, «расчесывала костяным гребнем мокрые, только что вымытые прозрачные волосы. Озеро отражалось не только в ее счастливых глазах, но и в каждой капле воды на ее теле. Словно она сама была уже не только озером, а безграничным, огромным, совершенным миром».

Чувствование, взаимопонимание друг друга, таинственная связь человека и животного нашли отражение в стихах всех ненецких поэтов и прозаиков. Письма оленевода Вэллы к таинственной Н. наполнены пытливыми наблюдениями за своими подопечными, описанием общения с ними:

\author{
Последний осенний дождь. \\ Действительно деревья плачут. \\ Олени так уныло смотрят на меня. \\ Как будто просят: оставь нас, \\ Не гони на стойбище в кораль-ограду. \\ Подсохнет снег, мы сами с радостью примчимся...
}

(Ю. Вэлла. «Этот совершенный мир»)

Устремленность оленей к свободе прочитывается поэтом, она подобна человеческим желаниям быть независимым и не запертым в ограниченном пространстве.

Мифологема оленя в литературе ненцев самая распространенная. Заботой о сохранении оленей пронизана вся кочевая жизнь.

Анна Неркаги в повести «Молчащий» - мрачном раздумье о судьбе своего народа, потерявшем к концу XX века свои традиции, обычаи, умение жить в гармонии с природой, «договариваться» с ней, называет в числе главных причин возможного «начала краха ненцев» «жестокое убиение оленя», то, что народ перестал видеть в олене «своего брата по жизни», прагматично использует его как средство для утоления голода.

Жизненный цикл ненцев, как и многих других народов Севера тесно связан с приумножением оленьих стад, с их оберегом. Действие в прозаических произведениях обычно развивается по установкам кочевья: со сменой времени года меняется место, пейзаж, поведение героев и животных, характер проблем и забот. Традиционно весной пастухи гонят стада к морю, где ветра спасают оленей от комаров и другого тундрового гнуса, а осенью уводят своих кормильцев на юг, ближе к лесу, чтобы укрыть их от холодных ветров и полярных волков. 
Волк считался одним из воплощений злого духа - нгылека, его настоящее название - сармик - почти никогда не произносилось вслух, его называли «тихий (ночной), бродящий ночью, длиннохвостый» (Л. Хомич). Это высокоорганизованное животное. В романе «Месяц Малой Темноты» Ледковым представлена ситуация, подтверждающая по-человечески разумную организованность волков. Сомнения и страдания героини, стремящейся обрести «свое женское счастье», автор усиливает неожиданным ночным побегом ее из чума в тундру и встречей с волком. Перед зверем Саване почувствовала себя «такой маленькой и ничтожной». Но «два зеленых огонька» и «глухое рычание» волка пробудили в ней инстинкт самосохранения и желание борьбы за жизнь. «Один прыжок, и зубы хищника вопьются в горло. Рука потянулась к прикладу винтовки, но так и осталась на полпути». Героиню спасает мелькнувшая мысль о поведении волков летом. Автор раскрывает ее: каждый ненец, едва покинув колыбель, уже знает, что волки летом не нападают ни на людей, ни на оленей. Даже если стадо разбредется широко, а волчье логово окажется посередине стада, волк со своим семейством осторожно отойдет в сторону, чтобы его не заметили пастухи. Женщина замерла и волк медленно ушел в сторону, не приблизившись к ней.

Согласно зоокосмологическим мифам о происхождении животных и растений волк - творение божества темных сил Нга, его предназначение - ловить оленей для подземного властителя. Отражены в мифах и метаморфозы, происходящие с волками. Так, в мифической песне лесных ненцев «Пятеро Тунго» волки представлены невероятно добрыми животными. Семеро волков оживляют девушку, которую погубил старый страшный муж. Этот мужчина под угрозой жизни всему стойбищу получил от братьев согласие на руку девушки и увез ее, сделав одной из многочисленных жен. Как оказалась, он был лесным чертом, а девушка нужна была для жертвы его матери. Семь волков не только оживили погубленную героиню, но и запряглись в нарты, повезли ее в стойбище братьев. «Помчались волки - только ветер свистел в ее ушах». В благодарность девушка стала их обильно кормить и попросила наказать обидчика. Волки-спасители старательно выполнили все ее просьбы: отвезли ее на высокую сопку и пригнали туда огромное стадо оленей злого старца.

В ненецкой литературе мифологема волка наполнена и положительными, и отрицательными коннотациями. Описано немало ситуаций, в которых пастухи защищают оленей, вступают в 
борьбу с хищниками. Волки наравне с людьми стали героями произведений Анны Неркаги «Анико из рода Ного» и хантыйского писателя Еремея Айпина «Божья матерь в кровавых снегах». В развитии сюжета, в создании образа мужественного, сильного духом и волей, наделенного добротой и широтой души, оленевода Себеруя в повести «Анико из рода Ного» стала многозначащей роль волка по прозвищу Хромой Дьявол, названного так ненцами «за хитрый ум и черные дела». Попав в капкан, он перегрыз лапу и переполнился дикой злобой к людям, не просто убил, а истерзал жену и маленькую дочь оленевода Себеруя. Семейная трагедия не изменила отношения оленевода к окружающему миру, не превратила в злобствующего одиночку. Автор проводит аналогию между двумя состарившимися и одинокими существами - человеком и волком. Мифологическому сознанию Неркаги и ее героям присуща эмпатия - глубинное проникновение во внутренний мир окружающего, общение с ним. Автор художественно воплощает реликтовое восприятие мира, где все равновелико человеку, и человек равновелик миру, позиционирует дискурсивную культуру состояния включенности в особую систему отношений с миром. Хромой Дьявол живет по законам, близким человеческим. Оставшись один, он крадет у своего соперника Рваное Ухо одного волчонка, воспитывает его, передает свои умения и проводит по известным местам, возвращаясь к Себерую.

В романе хантыйского прозаика Айпина «Божья Матерь в кровавых снегах», написанном позднее, активно развивается мотив эмпатии человека и волка. Героиня пытается установить бескровный и устойчивый мир с волчицей согласно традиционным правилам сосуществования с этим сильным и умным животным. Женщина, когда ее силы были уже на исходе, встречается с раненой Волчицей-матерью. Волчицу постигла почти та же участь, что и женщину. Волка и двоих детенышей расстреляли из-за бессмысленной удали с низко планировавшего аэроплана, а волчицу ранили. Выдавив из себя «жалостливый хрип», она, учуяв запах человека, поползла по нартовой колее. И здесь явление эмпатии, понимания между человеком и животным, не простым, а голодным и разъяренным, предстает в ярко выписанной картине. Женщина «не прикоснулась ни к ножу, ни к топору», не позволила собаке наброситься на волчицу, поскольку Высоконогая, так она назвала зверя, «остановилась на границе, отделяющей животный мир от человеческого». Главное, не перешла эту невидимую линию, не нарушила ее. «Стало быть, Высоконогая в 
своем разуме. Понимает, что можно, а чего нельзя», - решила женщина. Она заговорила с волчицей и прежде чем отправиться дальше, положила на дорогу косточки от сваренной птицы. И волчица прониклась сочувствием и благодарностью, не стала преследовать измученную женщину, с трудом тянувшую шкуруволокушу с младенцем.

Бытующий у северных народов трепет перед волком-хищником часто звучит в поэтических произведениях, в метафорах прозы. «Пурга сердитым волком // У светлых окон пляшет» так усиливает Иван Юганпелик состояние страха перед стихией и высвечивает радость защищенности от нее в доме.

«Есть упоение в бою»- эти слова могли бы стать лейтмотивом для стихов Лапцуя «Поединок» и «Битва» о схватках человека и волка, оленя и волка. Поединок деда лирического героя с угоняющим стадо огромным волком стал для него примером мужества и бесстрашия. В смертельной схватке сцепились волк и не побоявшийся вложить в его пасть сильную руку пастух. «Хрипел, рычал матерый волк/ глаза выкатывал зловеще, / но пальцы деда - словно клещи, / сдавили глотку - зверь умолк».

В «Битве» сражается с «кровожадным злодеем» молодой самец олений, защищая самку. Олень побеждает одного волка, но на помощь воющему от ран приходит другой - большой, матерый собрат. Он так щелкал зубами, так у него щетинилась спина, что «со страху схоронилась в тучу желтая луна». Но олень не отступил. Пастух выстрелом избавил его от врага. Когда же после битвы олень подошел «к подружке милой», пастух «навострил» свой чуткий слух и «услышал»: «Он сказал ей, что тройная / У мужчин бывает сила, / Если смерть крылом вороньим / Замахнется на подруг».

Мифологемы белого медведя у береговых ненцев и бурого медведя у лесных, нашедшие свое место в ненецкой литературе, развивались не без поддержки этиологических мифов-сказок. О том, чем отличаются медведи двух видов и почему они живут, не сталкиваясь друг с другом, можно узнать из мифа-сказки «Лесной и морской медведи». В борьбе определяли эти великаны свое местопребывание. Долго боролись, но после захода солнца решили отдохнуть и пришли к выводу, что не смогут одолеть друг друга, потому что морской сильнее, но лесной «вертлявее». Действительно, неуклюжие с виду лесные медведи необыкновенно быстры, ловки и проворны. «Беседа» зверей после по- 
единка привела их к консенсусу: морской медведь не будет доходить до леса, а лесной - до «горьководного моря».

Мифологема медведя тесно связана с созвездием. Как знак спасения для загнанных в «куропачий дом» геологов озарила светом тундру Большая Медведица:

$$
\begin{aligned}
& \text {...К утру Медведице Большой } \\
& \text { В берлоге тучи тесно стало. } \\
& \text { И над притихшею пургой } \\
& \text { Она на небе засияла. }
\end{aligned}
$$

(Поэма Лапиуя «Под звездами Ямала»)

Василий Ледков мифологему белого медведя также представляет в сопоставлении с созвездием Большая Медведица. В стихотворении «Тропический зной», изображая редкое явление в тундре - летнюю жару среди болот как несчастье, поэт привлекает метафору с участием медведя: «Проклиная жару и моля о пощаде, / Ковш Медведицы в небе ищет медведь».

В картине ночного северного сияния (стихотворение Ледкова «Опустилась ночь на Заполярье...») белая медведица представлена хозяйкой ледяных просторов:

\footnotetext{
И рыча на плоскости тороса,

Точно реактивный самолет,

Белая медведица торопко

Медвежат растрепанных зовет.

Мол, скорей, скорей сюда влезайте,

Посмотрите!

Ваша мать горда:

Ведь ее зовет своей хозяйкой

Этот край немереного льда!
}

По отношению к белому ледовому медведю, как и к лесному бурому, ненцы испытывали большое уважение. На острове Вайгач устраивали летом ритуал священной охоты на белого медведя с последующим жертвоприношением. Голову варили вне чума и ели ее только мужчины, женщинам не разрешалось даже прикасаться к костям. Кости съеденного животного обычно зарывали в землю, а губы зверя сохраняли на случай клятвы.

В стихотворении Лапцуя «Ночной гость» в воображении лирического героя возникает фантастическая картина встречи с бурым медведем. В полусне у костра он слушал байки геологов о медведях-шатунах, которые вылезают из потревоженных строи- 
тельством нефтяной трассы таежных мест, бродят по поселку, названному Медвежьим, «рычат удивленным басом». Неожиданно герой увидел, что к костру на задних лапах подошел «преогромнейший, как гора, с несердитым негромким храпом» медведь. Стал слушать байки о себе. Охотник с азартом схватив дробовик «метнулся на зверя сбоку», но медведь, вырвав и изогнув двустволку, захохотал:

Мол, неймется вам, люди в бой,
Но не писан закон жестокий
Для наказанного судьбой,
Для разбуженного в берлоге,
Не яритесь, мол, люди, зря!

Медведь ушел, строго взглянув на сидящих у костра, заставив их «устыдиться» за нарушение привычного для тайги миропорядка. Поэт как бы подтверждает бытующее мнение у многих народов о непредсказуемости, иррациональности поведения медведя, а также наблюдения зоопсихологов, что поведение медведя - в отличие от поведения лося, например, — чрезвычайно пластично, разнообразно и часто непредсказуемо.

Разговор с медведем при встрече традиционен для ненцев. Как правило, его просили уйти по-хорошему, но если убивали, то приглашали быть гостем. Разделанного медведя обычно везли на семи нартах, определив отдельно позвоночник, рёбра, две лопатки с лапами, задние лапы и жир. Голову и шкуру оставляли на месте, а вернувшись, отвозили на место жертвоприношения. Почтение и страх перед медведем были так велики, что название медведя - варк - использовали редко, чтобы обладающий тонким слухом и даром всеведения зверь не услышал, употребляли описательные его названия. О том, что название медведя варк ненцами почти не употребляется отмечено в этнологических работах Хомич: «Вместо него для бурого медведя употребляются слова: черный, лесной, одетый в черное, в берлоге находящийся, дедушка, священный, грешный» ${ }^{11}$. Автор пишет и о том, что для белого медведя типичны зоонимы белый, морской, а на его лапе приносят (приносили) клятвы.

В поэзии и прозе хантов мифологема медведя является также одной из самых выразительных. Микуль Шульгин в стихотворении «Медвежья пляска» воспевает архаичное и таинственное представление. Перед глазами читателя разворачивается ритуал, который не предполагает зрителей, все становятся участниками. Поэт передает всеобщий азарт танца, которым охвачены участни- 
ки праздника, посвященного добытому медведю: «Словно бы пурга крепчает - / Так отчаянно качает». Он подчеркивает верность «стилю дедов и отцов» при исполнении старинного обрядового танца, который требует строго определенного порядка. Молодой солист в роли медведя вовлекает присутствующих в хоровод.

\author{
На лице у парня маска. \\ Вот он топнул, как медведь. \\ Это ж вам — медвежья пляска! \\ Надо топать и реветь. \\ (М. Шульгин. «Медвежья пляска». \\ Перевод В. Кузнецова)
}

Следует отметить, что культ медведя существовал не только у ханты, но и у многих других народов Европы, Азии и Северной Америки, живших в лесной зоне - у манси, коми-зырян, кетов, эвенков, северо-американских атапасков, японских айнов и др. У большинства из них устраивались праздники по поводу убитого на охоте медведя в целях его умилостивления. Мясо съедали с соблюдением строгих обрядов. Перед тушей медведя устраивали танцы в масках. Этот праздник у большинства народов не сохранился. У ханты этот один из самых древних по своему происхождению и по сохранности традиций и ритуалов праздник проводится и в наши дни.

Описанная в стихотворении Шульгина миметическая «медвежья пляска» известна и у других народов Сибири, например, у манси, кетов, эвенков, нивхов, а также у индейцев Северной Америки. Ее исполняют зачастую в медвежьих масках и костюмах в сопровождении «медвежьих песен» перед предстоящей охотой или при удачном её завершении, а также во время главных празднеств.

Медвежий праздник называют «таежным карнавалом». По особенностям поведения он действительно во многом похож на карнавалы разных народов: во время праздника могут быть отменены установленные ранее правила, разрешается делать то, что обычно запрещено, например, можно высмеять в песне неудачливого охотника и даже шамана или отпустить острые шутки об интимной стороне жизни. Мужчины надевают берестяные маски, наряжаются в женские одежды, изображают птиц или зверей. Песни и пляски полны удали и бесстрашия. Карнавальная веселость становится приемом борьбы со страхом. Немецкий 
исследователь праздников карнавального типа у разных народов Ф. К. Ранг в статье, написанной в 1909 году, «Историческая психология карнавала» утверждал, что карнавал как спутник духа человечества, отражает страсти души. В эти дни «узаконенного беззакония» человек обретает свободу и освобождается от разных видов страха. И от «атавистического страха», т. е. воспоминаний о страхе перед ушедшим прошлым, и от «страха перед возвращением страха», т. е. страх перед неизвестным будущим, и от непреходящего страха смерти. Исследователь считал, что момент освобождения от страха имеет и еще одну сторону момент освобождения от собственного бесстрашия, переживаемый участниками карнавала. Это наводит на мысль, что в буйном кружении танца герои стихотворения Шульгина как бы освобождаются от страха, с одной стороны, а с другой - не хотят осознавать свое бесстрашие и кружатся до изнеможения.

М. Бахтин в работе о Рабле, как бы экстраполируя идеи Ранга, утверждал, что «веселое бесстрашие» невозможно в полной меpe, поскольку страх является конститутивным моментом серьезности и истинная веселость несовместима со страхом. Хантыйское народно-праздничное веселье во время медвежьего праздника, создающее целый ряд бесстрашно-веселых образов, как бы нейтрализует официальную систему тревожащего сумрачного мифа, восстанавливает амбивалентность и цельность, вносит в жизнь этноса устойчивость. Устрашающая и пугающая серьезность мифа как бы растворяется, уходят страдания и слабость, дух укрепляется для одоления последующих препятствий и сложностей. Главный герой стихотворения М. Шульгина «Медвежья пляска», вероятнее всего, согласно обычаям, тот, кто добыл медведя. Своим самозабвенным, захватывающим до головокружения танцем охотник как бы изгоняет не только свой страх перед верховным Торумом, отцом медведя, но делает причастными всех присутствующих на празднике, организуя хоровод. Рядом с ним, могут быть только мужчины. Совместно с женщинами танцы на празднике исполняются лишь после песен начального «звериного» цикла. Каждый должен станцевать для лесного гостя, иначе тот может обидеться и причинить неприятности. Ритуал предполагает участие всех присутствующих, на нем не должно быть посторонних. Ритуал - это самобытная, сакральная жизнь в мифе, внутри его текста.

Рассматривая таежный карнавал ханты не только как ритуальный праздник, но и как идею-образ, в основе которого «теле- 
патическое» чувство истории хантов, ощущаемое поэтами и писателями, можно отметить национальную самобытность в ритуалах ханты. Если обратиться к классификации Ранга праздничной смеховой культуры разных народов, то можно увидеть, что карнавальному смеху хантов не присуща, например, язвительная насмешка ритуалов вавилонян, это и не «смех счастья» греков. Представляется, что хантыйский увлекательный, наполненный священным смыслом смех можно назвать жизнеутверждающим, хотя и с трагическими элементами. Их карнавал отражает кризисную ситуацию, в которой человек как бы осознает добро и зло, отделяет их друг от друга. На празднике медведь выступает и как «звериный двойник» человека, которого раздевают и одевают, и как умирающее и возрождающееся божество, и как предок, тотем, и как культурный герой. В знак очищения от содеянного убийства своего первопредка ханты совершают обряд своеобразного покаяния.

Обряды, исполняемые на медвежьем празднике, несут не только сакральную нагрузку. Присутствующие радуются большой добыче, воздают должное мужеству человека и его отваге при добыче медведя: ведь в представлениях северных народов этот зверь - существо почти сверхъестественное, для победы над ним нужны храбрость, сила и охотничья сноровка.

Сакральное животное медведь у ненцев, как у ханты и многих других северных народов, считалось тотемным.

Наличие тотемизма (отождествление членами социальной группы себя с животным или растительным видом, соблюдение соответствующих этой мыслительной связи верования обрядов, пищевых запретов) у ненцев отмечено в работах ряда этнографов и историков. Так, Б. О. Долгих, в очерках по этнической истории ненцев и энцев названия некоторых родов у ненцев связывает с тотемами: Харючи («журавлиные»), Пырерка («щучий»), Ненянг («комар») ${ }^{12}$.

Для женщин существовали у ненцев особые запреты на еду некоторых частей тела животных. Женщина не могла, например, есть голову оленя, мясо медведя, некоторых рыб (щуки, сыра и осетра). Из почтения к медведям существовали даже особые правила пережевывания медвежьего мяса.

У историков и этнографов, рассматривавших вопросы тотемизма у народов Сибири, существуют достаточно убедительные свидетельства о его наличии у ненцев. Так, А. В. Золотарев в работе «Пережитки тотемизма у народов Сибири» ${ }^{13}$, обозначив кри- 
терии существования тотемизма у того или иного народа (тотемные имена родов, пищевые запреты, связанные с тем или иным животным, веру превращения человека в животное, происхождение человека от животного; какие-либо формы почитания животных, имена которых носят отдельные роды), считал, что достаточно наличия двух из них для утверждения существования тотемизма. У ненцев Золотарев нашел проявление тотемизма в родовых названиях и в запрете есть мясо тотемного животного. Исследуя зооморфные онгоны (духов), Д. К. Зеленин в главе «Онгоны ненцев» ${ }^{14}$ считал деревянные фигуры летящих птиц на шесте у ненецких чумов, болванчиков, представляющих медведя, волка, гагары, лебедя и др., следствием тотемических представлений ненцев.

Следует отметить, что существует и противоположное мнение у исследователей: Л. Хомич, а позднее Е. Пушкарева бытование тотемизма у ненцев отрицают. Можно лишь предположить, что мысль об отсутствии тотемизма у ненцев появилась из-за существовавшей у некоторых народов установки скрывать свою тотемическую связь. Однако фольклор ненцев - убедительное свидетельство тотемических представлений. Г. Д. Вербов в статье для энциклопедии иллюстрирует пример из собранного им материала: «Когда-то жили старик со старухой. Было у старика семь сыновей. Первый сын Харюци, второй сын - Вануйта, третий сын - Волк, еще один сын - лесной медведь, еще сын - белый медведь, еще сын-росомаха, еще один сын - Минлей (мифическая птица). И отпустил старик своих сыновей в разные места» ${ }^{15}$.

Фольклорист, поэт и прозаик Любовь Ненянг утверждала, что ее род связан с насекомым - комаром (ненянг — по-ненецки означает комар). Согласно мифам, насекомые - комары, москиты - связаны с нижним миром или повелителями нижнего мира, близки к хтоническим существам - мышам, чудовищам, связаны с тремя мирами. Иногда это посланцы, которым дана власть, могут превращаться в человека. Их связывают с тотемными предками. Стихотворение Любови Ненянг «Песня девочки из рода Ненянг» начинается словами:

\section{Я мала, как ненянг, \\ Но всю тундру свою \\ Я могу облететь!}

В стихотворении Ненянг «Комары» героиня вспоминает, как «Суетясь над дымокуром // Мать моя, старушка, машет // Дымною полою парки (парка - женская меховая распашная одежда) — // Комаров подальше гонит». 
В поэзии Явтысыя, Ледкова, Лапцуя предстает десакрализованная мифологема зловредного насекомого комара, от которого порой гибли целые стада, оставшиеся без поддержки человека, разводящего дымокуры.

В стихотворении «Рой комаров над стадом вьется...» Явтысыя зловредные представители хозяина нижнего мира предстают как упрек нерадивому пастуху - его задача - победить, «растоптать» лень, развести дымокуры и спасти оленей. Оставленные без присмотра олени могут погибнуть от туч комаров. У нивхского писателя Владимира Санги есть трагический рассказ «У оленевода есть сын» о погибшем от комаров оленьем стаде.

Лирический герой Явтысыя в стихотворении «Гнев» успокаивает свое сердце, обиженное на весь мир из-за дурных слов, сравнением их с «кровожадными комарами»:

«Сердце, // сердце, поутихни! // Ты же знаешь, // выгнать надо // из груди всю ярость гнева, // как из чума выгоняют// кровожадных комаров».

«Колыбелью комариного счастья» называет Ледков редкую и невыносимую для тундры жару, когда «дни и ночи гудят комариные свадьбы» (стихотворение «Тропический зной»).

При сравнении нашедших в ненецкой литературе представлений о тотемизме с чукотскими можно отметить, что в чукотской литературе нашла свое место расширенная художественная интерпретация мировоззренческих представлений чукчей о происхождении человека, о его родственной связи с животным миром. В повести «Когда киты уходят», которую А. В. Пошатаева назвала «древней тотемистической легендой» ${ }^{16}$, Рытхэу обратился к представлениям береговых чукчей о кровном родстве с китами, размышляет об истоках ритуальных праздников, посвященных киту. В основе произведения концепт первозданной природы, зарождение, последующее постепенное вытеснение природных инстинктов, естественных норм и утрата первородства. Писатель использовал легенду одного из прибрежных родов чукчей, согласно которой его предками являются первая земная женщина и кит, превратившийся благодаря Великой Любви в мужчину. Рытхэу не просто использует универсальный фольклорный архетип оборотничества, обращаясь к описанию самого раннего этапа развития человеческого сознания - мифологическому, а стремится прописать различные стадии и уровни этих мифологических представлений. Так, он прослеживает процесс изменения отношения чукчей к обратимому и необратимому оборотни- 
честву, к вере в кровную связь человека и кита, включая в сюжет жизнь и деяния героев нескольких поколений. Сюжет произведения проникнут мотивом запрета на убийство прародителя чукотского рода.

В начале повествования читатель знакомится с первозданным миром, в котором пребывает первая и единственная жительница земли Нау. Она живет в полном согласии с окружающим, не задумываясь об отличии растительного и животного мира, понимает язык птиц и зверей, даже камни считает «живыми и близкими». Ее отношение ко всему, что она видит, «живому, имеющему свой голос и крик, безмолвному, но движущемуся и пребывающему в вечном покое»- ровное и спокойное. И если для представителя современной дискурсивной культуры подобное переживание - большая редкость, воспринимаемая как нечто сверхъестественно прекрасное, то в архаичной культуре эмпатия составляла самую основу жизнедеятельности людей.

Древние народы антропоморфизировали стихии и природу, животный мир, стремились умилостивить их, восхваляя. На путях трансфизического и метаисторического познания мира, стремясь представить картину перспектив улучшения всемирного народоустройства, Даниил Андреев ${ }^{17}$ выделил актуальность приобщения литературы и науки к духовному миру разных народов, восприятия «лучей, льющихся оттуда в сердце, разум и совесть», осуществления во всех сферах жизни завета деятельной и творческой любви. По его мнению, именно обретенный в результате нравственный уровень, вполне отвечающий перечисленным признакам, называется праведностью.

В этом равновеликом мире выделение началось с рефлексии, проявления чувств, среди которых первична любовь. Однажды Нау «приметила» китовый фонтан и залюбовалась красотой и силой морского великана. С тех пор приближение длинного, блестящего упругого тела кита-великана, которое как бы светилось изнутри, солнечная радуга фонтана стали завораживать ее, манить, звать, «заставляя переступить безмолвный запрет, невидимый порог». И она не выдерживает, подходит близко к киту, а тот обволакивает ее фонтаном тепла и нежности. Нау впервые чувствует свое сердце, слышит его биение и, словно пробудившись, по-новому начинает воспринимать окружающий мир. Зарождающееся чувство любви обостряет все органы чувств, словно отделяет ее от природы, развивая умение видеть себя со стороны. Так пробуждалось, по мнению автора, человеческое 
самосознание. У Нау появляется ощущение вкуса: «она вдруг открыла, что морская вода отличается вкусом от той, что в ручье, а утренний холод исчезает по мере того, как над морем поднимается солнце». Особенно поражает ее возникшее понимание мира звуков: грохот бьющих о скалы волн, шелестящий звук ветра, плеск мелких волн в лагуне, журчание воды в ручье. Она открывает для себя, что звуки могут быть приятными или невыносимыми. «Зато птичий гомон над утренним ручьем Нау была готова слушать сколько угодно. В нем было что-то схожее с радугой над китовым фонтаном, и птичье щебетание рождало светлое ожидание предстоящего чуда». И чудо свершилось морской великан превратился в человека. Идея метаморфозы важный сюжетный ход автора, ярко раскрывающий чудодейственную силу любви. Возможно, впервые в литературах народов Севера так выразительно представлен момент зарождения человеческого ощущения любви, проявления ее нуминозности.

Великая Любовь земной женщины Нау и кита-оборотня Рэу становится лейтмотивом современной легенды Рытхэу. С любовью растят они своих первых детей-китят, а потом четверых человеческих детей. Покидая земной мир, Рэу дает детям строгий наказ помнить о своем родстве, быть братьями. Объясняет, что братство не во внешнем сходстве, а в сердечной склонности: «Мы пришли на землю, потому что есть высшее проявление живого - Великая Любовь. Она сделала нас людьми, сделала меня человеком. И если вы будете любить друг друга, любить своих братьев, - вы всегда будете оставаться людьми».

Честолюбивый, стремящийся властвовать над людьми и покорять природу, нарушая заветы предков беречь ее, Армагыргин перестает благодарить морских великанов за помощь в охоте и будучи удачливым охотником начинает верить лишь в свои силы. Убеждает в безнаказанности за поступки и других: «Мы настоящие хозяева земли! Все, что нам надобно, мы будем брать, не благодаря и не спрашивая об этом никого!»

От таких проявлений нелюбви прародительница Нау стала молчаливой, а потом и заболела. Когда же не знающий жалости, забывший слова добра и любви Армагыргин вместе с другими охотниками убил кита, не стало и вечной женщины. А пришедшие на берег разделывать убитого кита на следующее утро охотники увидели омываемого волнами человека. Так нарушение табу, жестокость и нелюбовь победили Вечную Любовь. 
Рытхэу сумел придать особую семиотическую значимость происхождению человека как началу моделирования культуры. Писателю близка мысль, что лежащие в основе миропорядка «первые» события не переходят в призрачное бытие воспоминаний - они существуют в своей реальности вечно. Каждое новое событие такого ряда есть нечто отдельное от «первого» его прообраза - оно лишь представляет обновление и рост этого вечного «столбового» события. Армагыргин нарушил общепринятые нормы, создал прецедент кровного убийства, и хаос не заставил себя ждать.

Как видим, в литературах разных народов Севера традициям приписывается сверхъестественная сила. Если они не сохраняются со всеми обязательствами, которые налагают, если святилища духов перестают быть таинственными местами, то жизненная связь между человеком и природой обрывается. Ни человеку, ни природе с тех пор не гарантировано существование.

Проблема сохранения древних традиций народа, возвращения добрых, тех, что благотворно влияют на самосознание и нравственный уровень жизни, постоянно волновала ненецких поэтов и писателей.

В своем творчестве они образно представляют обычаи и традиции, воспевая, например, красоту и глубину мифологем животного мира Севера. С искренней любовью к своему суровому краю, заботой об его экологии, передают их будущим поколениям.

Юрий Вэлла в стихотворении «Если не вернулся...» стремился психологически воздействовать на тех ненцев, которые не хотят возвращаться в «стойбище матери», не хотят заниматься оленеводством. Поэт привлекает зоонимы, напоминает народные приметы, свидетельствующие о трагической судьбе тех, кто не вернулся в родные места: если олень не вернулся в родное стадо по первому снегу, «значит его задрали волк или росомаха»; «если орлан-белохвост бросил гнездовье, значит, нашел где-то место безлюдное, «если сестра моя лебедь с весенней песней юности не покружилась над моим чумом, значит погибла от выстрела».

А если ты не зверь беззащитный

И не перелетная птица,

Если крылья твои целы,

Но дорогу не вспомнил

В стойбище матери,

Какую причину придумаешь ты себе? 
Мифологический генезис поэтического языка и многих поэтических символов и образов, связанных с зооморфическим компонентом, позволяет пролить свет на процесс трансформации, гипостазирования мифа в литературе, на синкретизм человека и природы, на способ моделирования окружающего мира ненцами и другими народами Севера.

${ }^{1}$ Окладников А. П. Утро искусства. М.;Л., 1967. С. 83.

2 Топоров В. Н. Животные // Мифы народов мира. Т. 1. М., 1980. C. $448-449$.

${ }^{3}$ Выготский Л. С. Психология искусства. М., 1986. С. 133.

${ }^{4}$ Мифы и предания ненцев Ямала / Автор-составитель Л. А. Лар; Иллюстрации Л. А. Лар. Тюмень: Изд-во ИПОС СО РАН, 2001.

${ }^{5}$ Житков Б. М. Полуостров Ямал. СПб., 1913. С. 50.

${ }^{6}$ Фольклор народов Крайнего Севера и Дальнего Востока России. М.: «Северные просторы», 2002. С. 113-114.

${ }^{7}$ Хор (ненец.) - олень-самец.

${ }^{8}$ Яра (ненец.) - местное название кустарника.

${ }^{9}$ Кассирер Эрнст. Избранное. Опыт о человеке. М.: Гардарика, 1998. C. 478.

${ }^{10}$ Там же. С. 479.

${ }^{11}$ Хомич Л. В. Представления ненцев о природе и человеке // Природа и человек в религиозных представлениях народов Сибири и Севера. Л.: Наука, 1976. С. 26.

12 Долгих Б. О. Очерки по этнической истории ненцев и энцев. М.: Наука, 1970.

13 Золотарев А. В. Пережитки тотемизма у народов Сибири. Л., 1934.

${ }^{14}$ Зеленин Д. К. Культ онгонов в Сибири. М., 1936. С. 94.

${ }^{15}$ Вербов Г. Д. Пережитки родового строя у ненцев // СЭ, 1938, Т. 2. C. 44 .

${ }^{16}$ Пошатаева А. В. Литература и фольклор (взаимодействие современных литератур народов Севера, Сибири и Дальнего Востока с устным народным творчеством). М.: Знание, 1981. С. 8.

${ }^{17}$ Андреев Д. Роза мира. Метафилософия истории. М., 1991. 


\section{Глава 4}

\section{ЧИСЛО - КОД МИРОВИДЕНИЯ НЕНЦЕВ}

В мифопоэтическом образе мира число является одной из важнейших категорий как средство устранения хаоса, моделирования Космоса. Рассматривая под мифологическим углом зрения символику чисел в тех культурах, литературах, где числа ещё не полностью десемантизированы, в частности, в культурах и литературах народов Севера, можно приоткрыть тайны мировидения человека исторического. Таинственная приверженность к тем или иным числам, выражающаяся в частоте упоминаний об этих числах в ритуалах, обрядах, орнаментах, проявляется в мифах и фольклоре, в литературных текстах присутствием архетипических образов и мотивов. Числовой символизм может приоткрыть глубинные духовно-психологические перемены в мироощущении северных народов, в эволюции сознания от хаоса к космосу. Что из бессознательного, называемого хаосом, ненецкие творцы - сказители, поэты, писатели - могли высветить на основе иносказания чисел, устремляясь к гармонии окружающего мира?

Решить задачу составить представление о числе как коде культуры ненцев в процессе комментирования мифов, эпоса, фольклора и литературы в контексте духовно-национальных воззрений непросто, но в ходе исследования сделана попытка приблизиться к ее решению.

Размышляя о роли в мировой культуре «сынов гармонии»поэтов, Александр Блок заметил некое единство хаоса и порядка, находящее свое место в культуре: «Мировая жизнь состоит в непрестанном созидании новых видов, новых пород. Их баюкает безначальный хаос, их взращивает, между ними производит отбор культура; гармония дает им образы и формы, которые вновь расплываются в безначальный туман. Смысл этого нам непонятен; сущность темна; мы утешаемся мыслью, что новая порода 
лучше старой; но ветер гасит эту маленькую свечку, которой мы старались осветить мировую ночь. Порядок мира тревожен, он - родное дитя беспорядка и может не совпадать с нашими мыслями, что хорошо и что плохо» ${ }^{1}$.

Ещё в глубокой древности числа относились к области тайного, сакрального. Они зашифровывались символами, но и сами были символами гармонии мира. В шестом веке до нашей эры древнегреческий философ и математик Пифагор считал числа не просто абстрактными заменителями реальных вещей, а живыми сущностями, отражающими свойства пространства и времени, энергии и звуковой вибрации. Он говорил: «Все вещи суть числа», утверждал, что числа правят миром, верил в их мистическую жизнь. Его убеждение возникло после изучения математических систем финикийцев и египтян, в результате освоения тесной связи этих систем с науками о природе человека. Он воспринимал число как скрытый в мире божественный первообраз, который, становится очевидным и зримым лишь при проницательном его созерцании.

Пифагор, его ученики и последователи верили в то, что человек, знакомый с магическими свойствами чисел, может менять свою судьбу, поскольку числа, подобно духам, бывают добрыми и злыми, приносят счастье или несчастье. Именно Пифагор и пифагорейцы, верившие в мистическую жизнь чисел, считавшие, что за каждым предметом обязательно стоит определенное число, заложили основы западной нумерологии.

Карл Юнг утверждал, что числа предшествовали сознанию и скорее открыты человеком, а не изобретены. По его мнению, числа, возможно, являются наиболее примитивным элементом порядка в мысли и подсознательно используются как организующий фактор. Пифагорейцы верили, что все вещи есть числа и их составляющие есть составляющие всех вещей.

В статье «О числовых моделях в архаичных текстах» В. Н. Топоров отметил, что число, являясь одной из важнейших категорий в мифопоэтическом образе мира, средством упорядочения и моделирования Вселенной, становится в народной традиции объектом «семантизации, символизации и оценки» ${ }^{2}$. Народная символизация чисел вошла в мировоззренческие установки авторов и героев в русской литературе, что нашло отражение в произведениях В. Жуковского, А. Пушкина, Ф. Достоевского, Л. Толстого, А. Чехова. Эти образцы могли повлиять на приемы использования символических чисел ненецкими авторами, кото- 
рые воспитывались на образцах классической русской литературы. Решающее влияние на появление в произведениях ненцев числовой семантики оказали ненецкие мифы, фольклор, героический эпос. Следуя принципу достоверного отображения жизни в мифах, а также в героических песнях сюдбабц и песнях бытового характера ярабц, в фольклоре - сказках, пословицах и поговорках, загадках — ненцы активно использовали числовую информацию. Однако семантика чисел в литературе зачастую отстранена от конкретики, обусловлена внетекстовыми ассоциациями, связанными с внутренним контекстом. Как средства скрытой сакральной информации чисел использовали и продолжают использовать ненецкие сказители? Как образно-художественное, мистико-символическое значение чисел воплощено в произведениях ненецких поэтов и писателей, в какой степени они подчинены законам ненецкого мифопоэтического преображения реальности? Эти и другие вопросы, связанные с поэтикой иносказания чисел в литературе ненцев, с мифопоэтической картиной мира выстроились в ряд для рассмотрения. В ходе исследования осуществлена попытка определения функции чисел в произведениях, значимости их в развитии сюжета, в создании образов, проводился герменевтический комментарий в контексте традиционных представлений ненцев о мире и человеке.

Для того, чтобы установить, какой тайный смысл вложил тот или иной автор в свою игру цифр, мы обратились к поиску следов мифопоэтической концепции числа, его «качественных» свойств, к символизму чисел в мировоззренческих установках ненцев и других народов, в первую очередь, народов Севера.

В числе первых ученых, выдвинувших предположение о существовании в древности у всех самодийских народов, к которым относятся и ненцы, семиричной системы счета, был финский исследователь Матиас Александр Кастрен ${ }^{3}$. В качестве обоснования мысли о существовании в прошлом у ненцев семиричной системы счета могло послужить, например, то, что названия первых семи чисел - простые слова, а, начиная с восьми сложно-составные. Число восемь по-ненецки «сидядет», что означает «два раза по четыре», два - «сидя», четыре - «тет» («дет» в другом говоре).

Число семь как завершающее семиричную систему счета ненцев, судя по мифологии, фольклору и литературе, обладает особой значимостью, наделено высокой степенью сакральности. 
Появление же современной десятичной системы счета у ненцев этнолог Л. В. Хомич связывает с развитием торговли и обмена с русскими, утверждая, что до этого была еще и девятиричная система отсчета. Потому, по ее мнению, число десять поненецки называется «луца ю»- русский десяток ${ }^{4}$.

Рассматривая число как фактор, обусловливающий своеобразие восприятия окружающего, фактор осмысления мира, мы более тщательно эксплицировали некоторые первые числа, входящие в семиричную систему счета, направив внимание на то, какой смысл, кроме количественного обозначения, сознательно или бессознательно вкладывали ненцы в числовые обозначения в мифах и фольклоре, как трансформировали традиционную нумерологию писатели.

Где кроется разгадка символики представленных писателем числовых обозначений? С этой целью - найти пути к разгадке иносказаний, связанных с числами, в литературе ненцев, обратимся к их восприятию в мифах, героическом и бытовом эпосе, в фольклоре четырех чисел: Единица. Два, Три, Четыре, Семь.

\section{Единица. Монада}

Самым первым числом, получившим свое обозначение у ненцев, как и других народов Севера, была Единица. Обладающая деятельным качеством, согласно сакральной пифагорейской символике чисел, единица в своем количественном и тайном значении представлена, например, в рассказе Леонида Лапцуя «Палочка с зарубками». Для пастухов, которые вели счет оленей по зарубкам на палочках, это был первый традиционный «калькулятор», о котором не раз писали основатели северных литератур.

Как основа всех чисел, символически означающая человека, единица может стать источником живых сил. При внимательном отношении к значимости единичного в содержании устного и письменного творчества можно увидеть приверженность ненцев к использованию числа один по отношению к человеку. В рассказе Юрия Вэллы «Наедине» предстает перед читателем молодой охотник, постоянно беседующий сам с собой, поддерживающий свои волевые устремления этим диалогом. Это рассказ о стойкости и выдержке человека, выполняющего нравственный долг. Охотник спешит, он должен как можно быстрее добраться на лыжах до ближайщего стойбища, чтобы там взять упряжку и помочь поранившему ногу напарнику, отвезти его к докторам. 
Он запрещает себе слишком ускорять шаг, чтобы не выбиться из сил, а также отдыхать, поскольку надвигается буран, пытается отогнать мысли о еде, об усталости и опасностях, продолжает, не останавливаясь для отдыха, целенаправленно продвигаться к далекому стойбищу. Герой один, он равновелик себе, он укрощает в себе бессознательные инстинкты расслабления, тренирует волю, пробуждая сознание.

В условиях суровой жизни и труда ненец постоянно оказывается наедине с собой, для преодоления трудностей он совершенствует себя и свою волю, стремится не отвлекаться от окружающих реалий, для поднятия духа часто сочиняет или повторяет личные песни, в которых обращается к себе в третьем лице.

Герой поэмы-сказки «Тёр» Леонида Лапцуя - пример культурного героя ненцев, который один борется за благо для народа, черпая силу и энергию из окружающего природного мира. Его победы подготовлены самосовершенствованием, готовностью к жертве, в чем-то подобны достижениям героев северных племен викингов. Победы у этих народов достигались благодаря фатализму, изначально встроенному в мифологию этих народов, не без рискованной жертвенности, ради обретения опыта и мудрости. У викингов (норманнов) на вершине пантеона был бог Один, умело выстраивавший приоритеты, считавший, что поражение не причина сдаваться. Уметь видеть правильный ход вещей, стоять до конца в самом безнадежном деле, заражать окружающих своими желаниями и волей - необходимые условия для выживания в постоянно экстремальных условиях проживания на Севере.

Мудрость, решительность и умение вдохновить других отличают культурных героев и ненецкой мифологии, эпоса, сказок, именно они помогли заложить основы создания литературного образа Тёра.

Мифы, сказки, героические песни сюдбабц и ярабц с их культурными героями обогащали «живущее сознание (или сознание самой жизни)» (М. Бахтин) извне идущей, оправдывающей и завершающей активностью, способствовали самосознанию жизни и самовыражению.

В ненецкой сказке «Побежденный кит» предстает герой, не соблюдающий правил скромного и почтительного отношения к стихиям - сильным ветрам, в море бушующим, а также к сильным морским зверям - к моржу с четырьмя клыками, к белому медведю, к киту с гребешком. Он вызывает их на борьбу, покоряет вопреки предостережениям отца и других жителей стойби- 
ща. Вай силен, ловок, хитер в борьбе, демонстрирует человеческую силу и волю, которые способны помочь и одному человеку освободить других от страха, отвести угрозу.

Подобное мироощущение героя способствовало формированию сознания сородичей, помогало им узнать и увидеть то, что было неизвестно. Такое видение, по Бахтину, с точки зрения действительной продуктивности события не есть наше слияние в одно существо и не есть нумерическое повторение моей жизни, но существенное обогащение события, ибо моя жизнь сопереживается им в новой форме, в новой ценностной категории - как жизнь другого человека, которая ценностно иначе окрашена и иначе приемлется, по-иному оправдана, чем его собственная жизнь.

В оценке образов мифов, фольклора и даже письменных произведений поэтов и писателей-северян зачастую присутствует определение их как некоего коллективного героя первобытного мира с одноплановым уровнем сознания. Нет должного внимания отражению специфики самосознания и самоорганизации человека, становления личности - Единицы. Обращение Юнга к глубинным слоям психологии ${ }^{5}$, сопоставление психики архаичного (начального, первозданного) человека и современного представителя человеческого рода привело его к выводу, что превосходство в дифференциации, возможность взглянуть с высоты достижений науки на разум и мир представителей иного времени не должны быть основанием для контрастного противопоставления. По его мнению, цивилизованный человек, несмотря на свой высокий уровень сознания, в более глубоких слоях своей психики все еще остается архаичным. Психологические исследования позволили Юнгу счесть несправедливым то, что ученые, в том числе и исследователь первобытного мышления Леви-Брюль, обычно подчеркивают чужеродность и различие с нашим сознанием, больше того, зачастую отвергают «разумную каузальность» у людей прошлого. «На самом деле первобытный человек не более логичен или алогичен, чем мы. Просто он думает и живет исходя из совсем других предпосылок по сравнению с нами» ${ }^{6}$.

Мифические герои способствовали осознанию ненцами своей единичности, значимости, обнаружению своей сути. Василий Ледков в повести «Синева в аркане» представляет образец самоосознания, нового видения себя благодаря знакомству с героем сюдбабц Нохо Нгацекы. Описывая сцены соучастия слушателей в событиях сюдбабц, автор подчеркивает эмоциональность восприятия, выделяет то, что песня стала «хозяином» в чуме, «все 
присутствующие время от времени поддакивали певцу и, восхищаясь неожиданным образом, поворотом мысли, удалью героя, цокали языками».

Сказитель пел с утра до заката и продолжил петь после чаепития до глубокой ночи. Во время перерыва слушатели не забывали о песне, вспоминали яркие случаи из жизни эпического героя Нохо, восхищались его силой и ловкостью, умом и волей. А главное - сопоставляли с реальными событиями из своей жизни, примеряли на себя заслуги героя. Пожилой Явтысый удивился выдержке и находчивости Нохо, который провел два года на льдине, поделился своими успехами: «Я всю жизнь ходил на морского зверя, все бывало, были и самострелы, тонул в ледяной воде, но, видимо, счастье меня не обошло стороной: ни разу не приходилось плавать на льдине». Молодой Егор Явтысый оценил свои силы и сознался: «Я бы, наверно, умер от страха».

Описанная В. Ледковым сцена восприятия героического эпоса ненцами - пример того, как жизнь слушателей обогащается событиями из жизни культурного героя Нохо Нгацекы, как они воспринимают их в собственной новой ценностной категории. Этот литературный пример свидетельствует, что слушание эпоса и соучастие - важное событие в жизни ненцев, оно является своеобразным образцом и для читателей, для формирования самооценки представителями нового поколения.

«Продуктивность события не в слиянии всех воедино, но в напряжении своей вненаходимости и неслиянности, в использовании привилегии своего единственного места среди других людей» ${ }^{7},-$ писал Бахтин. Постоянно оказываясь в экстремальных или близких к ним ситуациях, ненец, как и другой житель сурового Севера, остается один на один с собой и должен принимать решения незамедлительно, осознанно, защищать жизнь поступком, а не созерцанием. Один, единичность первостепенны, хотя и сложны для осознания в таинственном и суровом природном окружении. Миф поддерживал способность совершать разумные действия, создав возвышенного героя.

Мифологией, бессознательным устремлением к «вечному возвращению мифа» (Мирча Элиаде) можно эксплицировать воспевание, особое эмоциональное восприятие ненецкими поэтами числового значения «Первый». В северных краях в условиях циклического восприятия времени жизнь с каждым появлением солнца весной как бы возвращалась к истокам, к сотворению. Исток же связывается мысленно с появлением невероятной энер- 
гии, активизацией душевных и физических сил, с радостью. Наполнено ликованием, устремленностью лирического героя к новым деяниям в стихотворении Лапцуя «Первый день солнца»:

Солнце встает из летучей гряды

Нету его драгоценней сокровищ.

Первый день солнца -

день быстрой езды,

Праздник народа ненецких становищ...

В сакральной символике первичность ценится за то, что таинственным образом позволяет развиться качеству и таким образом приводит к множественности. Тот, кто решился на первый шаг в каком-то жизненно важном деле, должен помнить, что может привлечь подражателей и, соответственно, нести ответственность за него, как бы предупреждает Лапцуй в стихотворении «Первый шаг...»:

Первый шаг, хоть и не так

Он порою был тяжел,

Слыл всегда, как ни один,

Самым трудным первый шаг.

А за тем, кто сделать смог, Этот самый первый шаг, Хлынуть с тысячи дорог

Подражатели спешат.

Единица у пифагорейцев ставилась выше других чисел. От нее, согласно их мнению, пошел весь мир, она начало всего сущего, вселенной, самих богов. В представлении пифагорейцев число один - мужское, как и все нечетные числа, а следующее за ним четное два - женское.

О сходстве и различии восприятия чисел у других народов Севера в сравнении с ненцами, о значимости и роли чисел в развитии сюжетов, ситуаций, в создании образов представляется возможным сделать определенные выводы благодаря анализу произведений, в которых числа также становятся движущей силой, обладают магической энергией. Среди таких произведений рассказ Юрия Рытхэу «Числа Какота» и его роман «Магические числа». В основе обоих произведений своеобычное отношение чукотского охотника на морзверя, в прошлом шамана, Какота (в романе его имя Кагот) к впервые написанным им числам во время обучения грамоте, его глубокие раздумья об их энергии, возрастающей по мере увеличения, значимости числа в жизни че- 
ловека и влиянии его на человеческие судьбы. Рассказ был написан и издан в 1977 году, а роман, который стал своеобразным продолжением темы и идеи рассказа - через 10 лет, в 1986-году.

В основу этих произведений положены реальные события начала XX века: около чукотских берегов зимовал на корабле «Мод» норвежский исследователь Амундсен. Он пригласил Какота (Кагота), жителя соседнего селения, который владел разговорным английским языком, на работу поваром и сам научил его готовить. Во время обучения грамоте Какот (Кагот) раскрывает особенности своего чувственно-конкретного восприятия мира, специфику мифологического сознания. Он быстро усваивает азы арифметики, поняв, что чукчи считают не десятками, а двадцатками, что главное число счета у них называется «кликкин»это общее число пальцев рук и ног, что значит мужчина, человек мужского пола. Насущной необходимости в знании больших чисел у берегового жителя не было, поскольку для счета убитых моржей и тюленей было достаточно пальцев на собственных руках и ногах, а в более удачливые времена использовали пальцы всех членов семьи, которые всегда были на виду в теплом пологе, где надлежало сидеть без одежды и, следовательно, без обуви.

Изображение чисел на бумаге словно заворожило героя - он внимательно присматривался к ним, и они волновали его своими ассоциациями. Например, цифра пять, обозначавшая пять пальцев, в его раздумьях не только словно «заставляла» рассматривать свои руки, но и вызывала сравнение с крюком для большого котла. Охваченный стремлением постичь и ощутить силу чисел, а главное - силу новых для него больших чисел Какот (Кагот) стал старательно все пересчитывать и записывать на бумаге. Когда же не было бумаги, Какот «спускался на лед и железной кочергой писал цифры на снегу». Таинственную силу возрастающего количества он стал ощущать наиболее ярко, когда ему подарили большую чистую тетрадь, и он стал писать числа, прибавляя каждый раз единицу, в надежде на то, что достигнет магического числа, которое свершит волшебство - принесет удачу не только ему, но и всем сородичам. Числа становились в ряд, он не мог остановиться, «словно прорвалась снежная запруда и огромный шумный поток хлынул на чистые страницы тетради». Герою стоило больших усилий оторваться от тетради, но и «сквозь толстую обложку Какот чувствовал невидимую силу чисел, их таинственное излучение». В своих раздумьях он определил свое желание достичь магического числа как возможное, 
поскольку, по его мнению, ему удалось прикоснуться к духу больших возрастающих величин. В конце рассказа, как и в конце романа Амундсен предлагает герою покинуть корабль, поскольку из-за увлеченности числами тот не просто забывает о выполнении обязанностей повара, но и подвергает всех опасности пожара. Какот оставляет на корабле свою дочь и возвращается в ярангу. Но дальнейшая судьба Какота и его тетради не совпадают с судьбой Кагота. В рассказе герой неожиданно осознал, что числа могут не перейти в какое-то новое качество и чуда может не произойти, а он своим занятием написания чисел отошел от реальной жизни. И хотя числа прожигали белую камлейку, пронзали меховую кухлянку и сжимали болью истерзанное сердце Какота, вели себя, как живые сущности, он решил сжечь тетрадь и избавиться от них. Страницы горели на снегу медленно, словно числа «не хотели уходить в небытие, сопротивляясь всепожирающему огню». Вернувшись в ярангу, избавившийся от власти чисел герой громко сказал: «Пришел я - Какот!»

В романе Кагот не разочаровался полностью в поиске магического числа, хотя стал осознавать свой странный недуг и вновь обрел зоркость и проницательность охотника. Продолжая писать числа, стал замечать, что порой ему приходится прилагать усилие, чтобы открыть тетрадь. У него исчезло ощущение, что будто бы разгадка наибольшего магического числа совсем рядом. И это стало приводить его порой в уныние и растерянность. Однажды он вызвался пойти на поиски невернувшегося охотника, но сам оказался из-за перемены направления ветра на оторванной льдине. Кагот впервые почувствовал, что теперь, когда ему осталось только ждать и надеяться на милость судьбы, у него как никогда вдоволь свободного времени, чтобы писать числа... И снова он задумался: «Что же это такое - магическое наибольшее число? Может быть, оно - вот эта беспредельность пространства? Или вышина над головой, доступная только самым сильным птицам?»

С этими раздумьями о магических числах автор оставляет героя и читателей. Мы узнаем, что в селение вернулся тот, которого искал Кагот, а сам он не вернулся, хотя и ждали его все, согласно обычаю, до прихода нового льда.

Как видим, обладающая деятельным качеством, согласно сакральной пифагорейской символике чисел, единица в своем количественном и тайном значении представлена не только в ненецкой литературе, но и в других, в частности, в чукотской, где с 
помощью числа один герои старались найти предел, число, способное принести счастье народу, изменить его жизнь.

\section{Два. Двойка. Друада}

Число два означает, с одной стороны, единение, а с другой, как соединяющая две единицы, - противоположность. Карл Юнг неслучайно отмечал, что «противоположность энергетически равнозначна некоему потенциалу, а где существует потенциал, там есть возможность процесса и события, ибо напряжение между противоположностями стремится к выравниванию» ${ }^{8}$. Однако известно, что противоположность может провоцировать не только выравнивание, но и конфликт.

Встречу двоих как единение мужского и женского по законам мифологического творения космоса описал Прокопий Явтысый в стихотворении «Первый день весны...». «Самый первый весенний день подарил лирическому герою солнце, второй - тундру, третий - птицу, четвертый - зверя, пятый — дорогу, шестой встречу». Как итог - «Так для нас двоих мир был создан снова». Эта строка стала символом завершающего творение седьмого дня, когда двоих объединила любовь. Число два символизирует единение в восприятии поэта. Оно отражает один из аспектов традиционного представления ненцев об этом числе, о некоей связи его с числом семь - символом удачи. Эту перекличку можно найти и в мифологии. Так, в мифе «Приказания Нума Вэсоко» встречается число два как постоянное наряду с числом семь. Вначале мы узнаем о старике и старухе, которые живут далеко от домов. «Так они два года живут. Старик ходит на охоту или сети проверять, иногда приносит две рыбешки, а иногда одну куропатку». Когда же через два года старик разрешил жене пойти с ним, то ему повезло: семь куропаток в сети попалось, и в силках на куропаток оказалось еще семь. «Старуха несет несколько куропаток и две щуки». Числа два и семь сопровождают героев и сопутствуют удаче.

В названиях и первых строчках, предложениях некоторых ненецких мифов, сказок, героических и бытовых песен спрогнозировано развитие сюжета с участием двух главных героев, зачастую с противоположными намерениями и характерами. Так, волшебная сказка о великанах «Два Вэхэляко» начинается так: «Жили два брата, старший Вэхэляко и младший Вэхэляко. Старший Вэхэляко был женат. У младшего Вэхэляко жены не было. 
Старший Вэхэляко все ездил, а младший Вэхэляко все сидел между дровами». Обычно в чуме дрова находятся у выхода, там же сидят и самые обижаемые члены семьи.

Бинарность и взаимодействие противоположных сил добра и зла, возможно, появились у ненцев благодаря космологическим мифам о сотворении мира. Так, в мифе «Первые люди» два божества Нум и Нга вместе создавали жителей для срединного земного мира сразу после того, как хозяин небес Нум вылепил из глины мужчину и женщину. Вылепленные Нумом люди были мирными, а вылепленные из глины хозяином подземелья Нгой дрались и создавали хаос. Нум предложил Нге взять их к себе в подземный мир, чтобы он сам смотрел за ними и удерживал от плохих дел. Нга согласился, поставив условие: «А тобой вылепленные люди, Великий Нум, пусть живут наверху. Но они будут служить едой для мной сделанных людей». Потом Нум сделал дикого оленя, а Нга вылепил волка.

Своеобразное продолжение развития отношений между светлым, добрым божеством небес и темным, злым хозяином подземного мира находим в мифе «Первый человек и собака». Как уже отмечалось, в названном мифе старик Нум в один день сделал человека и собаку, чтобы та заботилась на земле о первом человеке - охраняла от болезней, помогала ему. Собака ленилась и забыла о наказе. Нум обнаружил, оторвавшись от небесных дел, чтобы проследить за порядком, что человека замучили болезни из-за плохой охраны, и прогнал собаку от человека. Нга воспользовался ситуацией, стал хвалить ее за лень, поскольку ему стало легче отобрать душу у человека без охраны и отправить его в подземный мир.

Основанная на числе два, заложенная мифами бинарность как способ осмысления мира, как фактор, обусловливающий своеобразие восприятия окружающего, стала константой при построении сюжетов, при создании образов как фольклорных, так и литературных произведений. Так, в сказке «Два оленя» о домашнем и диком животных раскрыты с помощью противопоставления беззаботная под охраной человека жизнь домашнего оленя и полное опасности бытие дикого.

Бинарность, обеспечивающая взаимодействие существующих в мире явлений и качеств (свет и тьма, свой-чужой, тепло и холод, добро и зло, и др.), магическо-символическая суть друиды были постоянным объектом для размышлений ненецкого поэта и прозаика Юрия Вэллы. Так, в побывальщине «Наивысшая форма 
гармонии» (определение жанра и название даны автором) он приводит ответы на вопрос, что же для каждого из собеседников разных профессий, собравшихся у костра в стойбище оленеводов, является наивысшей формой гармонии. Большинство определяют гармонию друидой-оппозицией: любовь и ненависть, свет и тьма, жизнь и смерть, война и мир.

Два неизведанных таинства - начало и конец жизни в миниатюре «Колыбель» Ю. Вэллы настраивают читателя на размышления о Вечном, о двух жизненно важных и необходимых делах, сопровождающих рождение человека и уход.

О таинственной мистической связи двух молодых людей пишет Юрий Вэлла в миниатюре «Поговори со мной», начинающейся словами: «Посреди тундры встретились две упряжки». Юноша и девушка ехали в разные стороны: она на учебу в город, он в оленеводческое стойбище. С первого взгляда искра любви зажгла их сердца, и они мысленно признались в этом друг другу. Вслух же обменялись лишь несколькими фразами о том, куда едут и как зовут. Упряжки умчались в противоположные стороны, но молодые люди мысленно продолжали беседу и слышали друг друга. Эпиграфом к рассказу-миниатюре взята ненецкая сентенция: «Изрекали Старцы издревле: Мысленное Слово, произнесенное с уверенностью, как слово, произнесенное вслух». Возникшее между двумя молодыми людьми чувство стало проводником их мысленных слов, связным, опередившим технические достижения связи.

Не без таинственного воздействия числа друиды в произведениях Юрия Вэллы развивается и человеческая дружба, в том числе между представителями двух северных народов, живущих по соседству. В рассказе о двух стариках - ненце и ханты, ехавших в одном обласе (лодке-долбленке), автор на фоне манифестации мастерства сказителей подчеркивает тесную связь жителей разных родов, представляющих разные народы. У ненца было хантыйское имя Явунко - это значит, что он был известен не только среди своих сородичей, но имел уважение и среди ханты. У старика же ханты по этой же причине было ненецкое имя Капитяай. Обмениваясь сказками, два старца так увлеклись, что встретив двуглавый речной поворот, поехали не вниз по реке, куда им надо было, а поплыли вверх по течению. Этот двуглавый речной поворот сыграл с ними шутку: увлекшись сказками, забавляя ими друг друга, старики здесь «ночевали и первую ночь, ночевали и вторую ночь». В результате два друга, увле- 
ченные сказками, «перетащились через один и тот же волок семь раз». Такова сила настоящего искусства истинного сказителя они забыли обо всем на свете. Колдовская, мистическая сила чисел, в данном случае в первую очередь числа два в сочетании с семеркой, идущая из глубины веков, стала действенной, оказала влияние и на поведение героев, и на развитие сюжета.

Семейное единение мужского и женского у ненцев, как и других народов Севера, было обозначено противопоставлением, особыми правилами поведения, нарушение которых приводило к конфликтам, а порой и к жестокой расправе с женщинами. Сюжеты поэм В. Ледкова, Л. Лапцуя, эпизоды из повестей А. Неркаги и других писателей - убедительное доказательство бытования у ненцев двойственного отношения ненецких мужчин к женщине, о влиянии мифологических представлений на разделение мужского и женского.

Представляется интересным разгадывание силы двух синеватых оленей, встреченных в мифической песне о Младшем Хэно, который собрался в далекие края и стал внимательно осматривать свое стадо, чтобы найти хороших и сильных оленей. Его внимание привлекли два необычных по окраске оленя, похожие на синеватый туман, с блестящей на солнце шерстью. Олени стояли около входа в чум. По указанию Младшего Хэно работники поймали двух синеватых оленей, чтобы запрячь в нарты, но его сестра не позволила этого сделать. Она посоветовала взять их с собой и запрячь тогда, когда будет совсем трудно в жизни, вероятно для того, чтобы воспользоваться их сакральными способностями. Кроме того, с их помощью Младший Хэно мог обратить внимание проезжающих мимо - согласно традиционным установкам, увидев упряжку с одним или двумя оленями, оказавшиеся рядом должны быть внимательными к ездоку, поскольку неполная упряжка - свидетельство того, что в жизни его произошло что-то необычное.

В качестве волшебных помощников Тёру в поэме Лапцуя дала старушка (сестра отца) две ивы со словами: «Ивы - сородичи предков твоих. // Видишь ли пару обнявшихся ив?// Пни их ногою - и там, где стоишь, // Лягут на снег они парою лыж». Действительно, эти ивы-лыжи оказались для героя «быстрокрылыми» помощниками.

Ивы выступают в поэме символом древа жизни рода Тёров, в их ветвях различил герой черты отца. 


\section{Три. Тройка. Триада}

Для двоих, пребывающих в этом мире, значимость третьего подсказывает философская притча Юрия Вэллы «Утром у озера». Два тумана - розовый от озера и фиолетовый из леса шли и вели знакомство-беседу, сожалея, что не видят друг друга. «А в это время олень лежал рядом в кустах, жевал жвачку и все видел и слышал» о содержании беседы. Присоединившийся к двум герой создал тройку как символ знания и понимания.

Тройка издревле почиталась всеми народами как знак, сопутствующий гармонии и равновесию. Создавая предполагаемый резонанс Души с Космосом, число три благотворно действует и на человеческие возможности. Пифагорейцы считали, что Тройка несет в себе уверенность и силу, так как если один или два раза могут быть совпадением, то три раза - это уже закономерность.

В древности число три олицетворяло самую меньшую по количеству родовую общину, маленькое «племя». В мифах, эпических песнях, сказках ненцев также есть обозначение рода-племени числом три. Так, эпическая песня «Вада-сюдбабц» («Слово-песня») начинается с представления героев. «В этом чумике живет старуха. Она растит двух детей, один - сын, другая - дочь». В процессе развития сюжета выясняется, что эти трое составляют род Ябта Саля, в прошлом богатый и многочисленный, но потерпевший поражение в сражениях с Ханом Хаденготой. Выделяется соединение одного и двух в число три. В другой эпической песне сюдбабц героями являются три оленевода Пуця, которые имеют тридцать чумов. Род составляют три брата, владеющие стадом.

Символика числа 3 как образа рода просматривается у ненцев в паремии, например, в загадке: «Три рода в одном стойбище находятся». Отгадка: копье, хорей (шест для управления упряжкой) и костяной наконечник. Загадка метафорично определяет три издревле жизненно важных для ненца бытовых предмета. Три символизирует здесь и множественность, большое количество выполняемых функций этими предметами. Число три в фольклоре ненцев часто определяет количественное время: «Так прожили они три года», «Прожили еще три года».

В повести Анны Неркаги «Илир» число три усиливает напряжение описываемого эпизода, позволяет автору раскрыть в развитии и многосторонне характер одного из главных героев. Однажды Майму окружили три волка. Два из них не выдержали напряженного, полного силы взгляда оленевода и убежали, а 
третий, крупный, с гладкой лоснящейся шерстью, стал медленно приближаться к Майме. Тогда оленевод взялся за нож. Главным для него было в тот момент - не поддаться испугу и не побежать. «И Майма, собрав все свои силы, напрягшись так, что кровь стучала в висках, ломило руку, сжимавшую нож- не двинулся с места. В нескольких метрах от человека волк замер, будто готовясь к прыжку. И вдруг... повернулся, поджал хвост и потрусил прочь». Неркаги объясняет это превосходство оленевода и бескровную победу над тремя волками тем, что Майма благодаря своей могучей воле стал подобен свирепому вожаку стада, который в любой момент готов смять, растоптать все стоящее на пути. Этому умению держаться с достоинством, гордо, как подобает истинному хозяину, он научился еще мальчиком. Уже в детстве он смотрел вокруг так, будто выслеживал зверя. Эта обретенная в детстве охотничья уверенность помогла Майме «пересмотреть» волка, испугать его.

Автор нагнетает ситуацию, усиливает трагедийность встречи с волками числом три как воплощением силы. При этом обращает внимание на то, что триада состоит из друады и монады, но в этом сочетании монада является основой, подчеркивает силу монады. И словно в подтверждение этой мысли, постепенно сила и мужество героя под влиянием обстоятельств и страсти к наживе, богатству, стремления к власти превращаются в разрушающую жестокость и злобу.

Число три в романе В. Ледкова «Месяц Малой Темноты» также использовано автором в сцене описания коварных действий неспособного удержать страсть к наживе оленевода Тэси. Герой отправил своих пастухов на бандитский разбой, и когда те вернулись раньше срока, он на всякий случай, чтобы скрыть волнение, зевнул и сказал, что ждал их через три дня. Участник воровского налета на соседнее стойбище уточнил добычу: «Одерма из каждых трех оленей одного не досчитается...». Триада использована автором, чтобы усилить трагичность совершенного зла.

Число три в названном романе Ледкова сопровождает сомнения героев, выступая символом неустойчивости. Пастух Варук Вась размышляет о совершенных им нарушениях правил тундровой жизни - взял добычу из чужого капкана, угнал оленей из чужого стада - пытается определить правильный жизненный путь в течение трех дней под вой ветра, беспорядочное кружение снежинок, расплывчатые пятна мохнатых звезд в просветах снежных туч и тревожное гудение земли и неба. 
Число три использует Ледков и для того, чтобы усилить волнение героини. Оно нагнетает драматизм событий в описании ожидания героиней Саване своего возлюбленного: «Вот уже третью неделю жила Саване одна». «Третья неделя шла к концу, а Егора все не было». Оказалось, что к тому времени герой уже свел счеты с жизнью, не выдержав имеющихся и возможных изза сложившейся ситуации трудностей.

Число три, символизируя тройственную природу Мира, его разносторонность, триединство созидающих, разрушающих и сохраняющих сил Природы, с одной стороны, вносит примирение и часто сопровождает удачу, а, с другой - способно принести злое начало.

Леонид Лапцуй в поэме «Тёр» явные числовые моменты использования числа три сочетал с конструктивно-символическими формами числового иносказания, и это несомненно отразилось на создании эффекта гармонически организованного текста. Поэма пронизана троичностью. Приобщение к поэтике триады в поэме дает возможность приоткрыть тайну сакрального воздействия числа три, того потаенного смысла, который сознательно или неосознанно использовал автор. Число три в поэме наполнено символикой и знаками. Мир как особое пространство значений, по Хайдеггеру, невозможно понять как чистую открытость, чистую возможность, которая для бытия невозможна, поскольку любая чистая возможность неопределенна. Понять или хотя бы подойти к пониманию мироощущения, восприятия бытия в прошлом можно лишь через событие, даже если оно выражено через измененное «понимание бытия» человеком с иным бытийно-историческим мышлением. У Лапцуя, как и других поэтов-северян, мифологическое понимание бытия генетически заложено и отдалено не слишком большим временным отрезком от современного миросозерцания, хотя и подверглось трансформации. Судя по содержанию, художественному воплощению в поэме-сказке «Тёр» жизненных установок далекого прошлого, у автора было глубинным освоение мифопоэтики героического эпоса ненцев. В основу поэмы «Тёр» легли события из песен сюдбабц. Мировосприятие же героев поэмы интерпретировалось с позиций автора с уже обновленным бытийно-историческим сознанием. В нем сочетаются открытость и сакральность. В частности, автору была интересна магия тройной структуры, числа три, проявляющаяся в мифах, фольклоре и эпосе ненцев, интеграция двойственности и единичности в структуре триады. 
В ненецких мифах числом три выражается вертикальная модель мира, как и в мифах других северных народов, выделены верхний - небесный, срединный - земной и нижний - подземный миры. Два божества, два брата (согласно некоторым мифам, их родственная связь определяется женами-сестрами) Нум, носитель света и добра, и Нга, воплощающий тьму и зло, оспаривают постоянно между собой власть в срединном мире. Своеобразным выравнивателем этих борений выступает третья божественная сила - Я Миня, Богиня Земли.

Именно к ней обращаются герои сказок, литературных произведений. Она присутствует как некая тайная сила, способная помочь, во многих поэмах и стихах Лапцуя. Действие в поэмесказке «Тёр» в основном развивается в срединном мире, но присутствуют ситуации, когда оно перемещается и на небо, и в подземный мир. Трижды Тёр был смертельно ранен: «Трижды сгибнув и воскреснув, начал он свой путь мальчишкой», на краю гибели был в сражениях не раз. И когда однажды в очередной раз «умирал», ему, словно во сне представилось воскресение: «Солнце, кинув небосклон, // Обернулось птицей, // Как над сыном, из очей// Слезы проливает // И для Тёра из лучей // Колыбель свивает. // Тучки-лебеди плывут // Над земным простором, // В клювах бережно несут // Колыбельку с Тёром».

Художественный вымысел поэта с опорой на числовую символику ярко проявился в динамике характера героя, в формировании личности, мужественно перенесшей все выпавшие на его долю испытания, вызывающей уважение, а также интерес к истории народа. Тёр как личность в поэме изначально единичен, позднее появляется жена, далее сын. Создавая в процессе развития фабулы триаду (становление и укрепление единицы, создание двойного единения, прибавление к двойственности третьего), поэт обозначил свое стремление к гармонизации мира. С активным участием магического влияния триады развивается и сюжет поэмы. Сражались за земли два рода, в каждом из них по три брата, как в том, который жил праведно и богател прибылью своих оленей, так и в другом, враждебном, вероломно ночью напавшем. Три брата - защитники рода Тёр были смелыми и сильными, поддерживали друг друга в битве, сражались храбро, но погибли из-за неравенства сил, а главное - из-за внезапного ночного нападения захватчиков. Спасенный старшей сестрой младенец вырос богатырем и вступил на тропу войны с тремя врагами Ваями. Среди трех братьев самым ответственным за судьбу рода был 
третий, старший брат как у Тёров, так и у Ваев. У Тёров отец главного героя как старший брат первым среди шума ночной грозы «шорох услышал шагов незнакомых» и «вылетел птицей в дыру дымохода». У Ваев особой хитростью и жестокостью в желании избавиться от юного Тёра обладает старший, который даже когда стал седым и старым, не терял чувства ответственности за двух других братьев и род в целом, не утратил внутренней силы и осторожности. В числе три действует своеобразный расклад один плюс два, однако некое единство, гармония достигаются за счет превалирующего числа один как основообразующего. Именно такое противопоставление способствовало как усилению драматизма действия, так и созданию выразительных характеров.

Имена Тёр и Вай, состоящие из трех букв, словно определили судьбу каждого из них, разделили их. Герои имеют характер, в котором выделены по три наиболее важных и значимых особенности. Положительные качества - оптимизм, дар предвидения, умение словом и делом обратить на себя внимание и заставить поверить в правоту отличают Тёра. Неумение прощать обиды, эгоцентричность, склонность к своеволию присущи Ваю.

В стойбище Ваев выделил Тёр острым взглядом «рослых три чума» - чумы трех братьев Ваев. Остальные для него - лишь фон: «множество маленьких лепится с краю». Хотя для читателя замечание автора раскрывает отношение братьев Ваев к своим пастухам и другим родственникам - у них не было щедрости Тёров.

Сюжет поэмы-сказки развивается под сакральным влиянием триады. Тёр трижды приходит к Ваям, возвращаясь вновь и вновь, несмотря на смертельную опасность. Столь велики у героя вера в торжество справедливости, желание нейтрализовать агрессивность Ваев проявлением своей доброжелательности и доверия к обещаниям, надежда на то, что доброта победит зло силою примера. И только после третьего проявления неуемной жестокости Ваев, будучи на краю гибели, обратился герой к Трехкосой и при ее поддержке расправился со злобными обидчиками. Женщине в грозном сражении помогали три волшебные косы.

Традиционно в мифах и фольклоре ненцев, как и многих других народов, в качестве помощников у героев оказываются или им предлагаются три волшебных предмета.

Старшая сестра отца Тёра, спасая его еще младенцем, взяла с собой три вещи: «Сунула я в сыромятный мешок// Пару кисов (кисы - меховая обувь) ненадеванных, новых// Женский мой нож шириною в вершок, // Бубен старинный из замшевой кожи». 
Три предмета важных для выживания и спасения оказали жизнеспасительную поддержку не только ей, но и подрастаюшему богатырю. Собирая Тёра в неизведанный опасный путь, она дает ему кисы, бубен, а в качестве верных и всесильных помощников определяет трех медведей. С помощью бубна, взятого ею из родового стойбища, женщина держала постоянную связь с Тёром, поддерживала в трудную минуту.

Немало услуг оказали герою три медведя, которых женщина определила Тёру в помощники со словами: «Ежели встретишь недобрых людей, // Помощь получишь от трех медведей». Троекратное действие обеспечивало Тёру свершение волшебства. «Правой рукою три раза взмахни - // С моря как ветер примчатся они», — учила наставница Тёра.

Велика роль волшебных предметов в развитии сюжета поэмы-сказки. Когда после злобного почти смертельного удара свинцовой колотушкой старшего Вая не ожидавший его юноша Тёр очнулся и вернулся в мир живых не без поддержки волшебного бубна. Пойти же на лыжах из-за онемевших ног герой не смог. Он «словно бы ходок плохой, // вставал и падал трижды». Трижды означает, вероятно, в такой ситуации беспомощности «большое число раз», что характерно для проявления триады в фольклоре. Вспомнив про помощников старушки, Тёр трижды взмахнул рукой, и перед ним «белы, как луна, три появились медведя» и понесли, словно олени, лыжи-упряжку. На этой чудоупряжке помчался Тёр вслед за кочующими на юг Ваями. Когда приблизились к кочевью Ваев, юноша отпустил медведей, трижды поклонившись трем неразлучным друзьям.

Жестокость и коварство Ваев с каждым разом возрастали. На этот раз старший седой Вай ударил Тёра колотушкой, покрытой ядом.

\footnotetext{
Трижды он юным лицом холодел

Под колотушкою страшной.

Трижды, восприняв, на лыжах летел, Правя медвежьей упряжкой.

Трижды сироткой у гиблой тропы

Ползала Мынико-песня,

Трижды велением мудрой судьбы

Бубен вещал в поднебесье.
}

Троекратные почти смертельные удары хитрый Вай объяснил непобедимому юноше как попытки проверить его на способность выживать в тундре и с помощью софистики позициониро- 
вал свои злые поступки как доброе дело. И Тёр доверчиво пошел к Ваю в ученики-батраки. Не поддается человеческому восприятию жестокость хозяина-учителя, пытавшегося юношу согнуть непосильным трудом. Но Тёр «никогда не проклинал судьбу», а набирался сил.

Юный богатырь Тёр, отправившись защищать род, нашел лук своего отца: «Тяжек тот лук длиной в три аршина. // Тёр хоть пытался, а с места не сдвинул». Прибавление силы в ходе неравных сражений с Ваями позволило Тёру позднее воспользоваться луком отца и победить.

Временной промежуток измеряется в поэме числом три. С его помощью создается тревожное напряжение. «На рассвете третьих суток // вышли горы-глыбы». Это были предвестники «ледового аркана» и опасного развития событий. Наобещав много даров в будущем: красивую невесту, власть над тундрой, Вай убедил Тёра помочь ему. Доверчивый юноша с поддержкой медведей разогнал льды. Но в благодарность Вай уговорил капитана парусника напоить Тёра, выведал тайны его силы, узнал о помощниках - источнике его выживания. В отключенном состоянии Тёра выбросили на лед. Медведей посадили на цепь в клетку, а ивы вырвали с корнями. Спасением для Тёра стала Трехкосая, которую он встретил в царстве великанов.

Любовь пронзила сердце Тёра, и он предложил девушке выйти за него замуж. Согласившись, Трехкосая срезала одну из кос и сплела серебряный ковер. На нем молодожены отправились в края обычных людей. Три волшебных косы становились поддержкой и спасением для героев по мере развития действия.

Пролетев «облаков трехслойные пласты», пробудившись на третьи сутки, Тёр отправился освобождать из плена своих помощников - трех медведей.

На этот раз увидели Ваи уже не юношу, а мужчину. Их коварство и жестокость возросли. Старший «все тревоги усыпил лисьим разговором», устроил пир, и поняв, что Тёр безоружен, направили его якобы к купцу, а в реальности к месту гибели отца его и стали с трех сторон стрелять. Накопивший силы Тёр сумел поднять лук отца и стал стрелять в ответ, но был до этого сильно ранен, потому оказался «от смерти за вершок». На помощь ему пришла Трехкосая, которую он мысленно позвал. Отрезав вторую косу и распушив волосы на стрелы, женщина вступила в сражение против Ваев. Но победить не удалось, и тогда женщина отрезала третью косу, чтобы клинком, в который превра- 
тилась третья коса, сразиться с Ваями и спасти мужа. Меч этот она упрочила заклинаньями и трижды перепрыгнула через него.

Осознав превосходство Трехкосой, враги «распластались в ногах» ее и стали просить пощады. И женщина, в отличие от жестокосердных противников, проявила великодушие, подарила им жизнь и свободу в обмен на обещание приносить людям пользу.

Спасать трех медведей Тёр поехал через тайгу на оленях и услышал приближение всадников на конях.

\section{Три дня искрили-цокали \\ Коней копыта резвые.}

Тёр вступил в сражение с ратью, чтобы поддержать встреченного в пути друга:

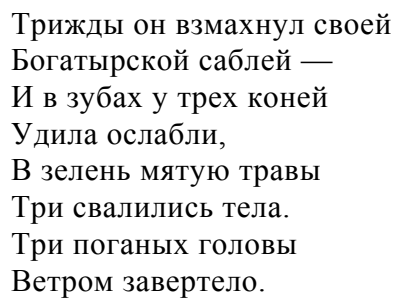

Триада и далее сопутствует и помогает Тёру. Число три владелец небесных даров на земле, число удачи. Оно использовалось ненцами в заклятиях, часто обращенных к востоку. Именно поэтому, когда приехали иноземные гости, герой «По обычаю воззряся на восход, // Трижды стукнулся молитвенно об лед». Космические силы поддерживают Тёра в его праведном деле даже без обращения с просьбой: «три бесхвостые кометы кто-то видел в тучах».

Число три в поэме-сказке Лапцуя - идеальная модель жизненного процесса, пример динамического возникновения, развития и реализации идеи собирательного образа защитника народа. Проявление триады как основной константы мифопоэтического макро- и микрокосма было постоянным в поэзии Лапцуя. В стихотворении «Битва» о том, как победил олень волка и защитил стадо, поэт вновь подчеркивает живительную силу триады словами победителя своей оленихе:

Он сказал ей, что тройная

У мужчин бывает сила,

Если смерть крылом вороньим

Замахнется на подруг. 
Собиратель ненецкого фольклора, поэт и прозаик Юрий Вэлла находился под особым мистическим влиянием чисел, стремился разгадать их магическо-символическую суть. «Триптих» - так уточнил он название созданной им на основе мифов, эпоса и фольклора, а также собственного оленеводческого опыта (до конца дней он жил в оленеводческом стойбище Варьёган), написанной им «Азбуки оленевода». В нее вошли «Поговорки оленевода $(3 \times 7) »$, «Арифметика оленевода $(2 \times 7) »$ и «Кое-что из “сакральной азбуки"» (1х7). Структурно-цифровое уточнение, сделанное автором, имеет количественное обозначение, уточняет, сколько народных рекомендаций содержит каждая «семерка», но можно предположить и символическую подоплеку, вложенную в то или иное повторение семерок, подсказывающую, почему автор взял именно данное количество.

Часть предложенных молодому или начинающему оленеводу поговорок-рекомендаций содержит сакральное для ненцев число три. Так, бывалый оленевод предупреждает о сложностях, связанных с дикими оленями: «Из дикого оленя воспитать домашнего можно, но только в третьем поколении. Отбить своих оленей от стада дикарей трудно, но возможно. Для этого Природа тебе отпускает три попытки в первые три дня, из которых наиболее вероятна только первая попытка».

Далее автор сопоставляет результаты, которые мог получить трудолюбивый или нерадивый оленеводы: «Оленя вырастить, приручить надо три года»; «Для того, чтобы утратить, запустить стадо - достаточно три дня». «Труд оленевода сопряжен с постоянной заботой о сохранении стада». Три условия надо соблюдать, чтобы сохранить оленей: забыть о сладком сне, о вкусном обеде, о сухой одежде.

Сама природа и ее законы, по мнению автора, руководствуется числом три при определении образа действий как человека, так и животных. Например, олени, как и люди, придерживаются тройственности в своих действиях: «Разожги дымокур до прихода оленей, а не после. Если твои олени три раза пришли, а дымокур еще не разведен, они могут больше не прийти».

Число три активно участвует как в развитии сюжетов, в композиционном построении, так и в создании образов. 


\section{Чemblpe. Тетрада}

Имеющая устойчивую структуру четверка в мифах о сотворении мира и ориентации в нем присутствует как эмблема Земли у индийцев и ассоциируется с негативом у японцев - они избегают ставить этот номер при определении квартир, домов, этажей. У пифагорейцев четверка - символ человеческой души, ее совершенства, они использовали ее в клятве: «Клянусь тем, кто придал нашей душе (вид) четверки». Квадрат как аллегория числа четыре стал образом в искусстве. Гиппократ выделял четыре темперамента. Считая, что божественная четверка управляет жизнью человека, Юнг выделил четыре функции тетрады: интуицию, ощущение, мысль, чувство. Он считал, что поскольку главные символические фигуры любой религии всегда выражают определенную моральную и интеллектуальную установку, то состоящий из четырех направлений крест воплощает в себе идею устроения и является древним символом строя и порядка.

Василий Ледков в первой части романа-дилогии «Месяц Малой Темноты» (как уже отмечалось, вторая часть носит название «Люди Большой Медведицы»), представляя картину камлания шамана, знакомит читателя с ритуальными действиями, в которых числа наполнены не только количественным, но и сакральным смыслом. Числовые обозначения придают картине камлания таинственности, способствуют динамике развития действия.

«Из чума вышел шаман. Он огляделся, низко поклонился четырем сторонам света. Затем Длинноволосый семикратно обошел избранную жертву (оленя) по ходу солнца». Потом шаман обратился ко всем четырем сторонам света с заклинанием. Подойдя к жертвенному оленю, он трижды провел вокруг его шеи шкуркой горностая и, встав на колени, обратился с заклятиями к солнцу.

Четыре стороны света - как одна из основ вечной устойчивости и внутримирового порядка вещей, сакральны и обожествляемы.

Особенностью восприятия четырех сторон света у ненцев является их эмоциональное бинарное деление на «два плюс два»: север и юг, которые олицетворяют холод и тепло, запад и восток - тьму и свет. На юг, спасая оленей от холода и темноты, перекочевывают ненцы осенью и возвращаются на север лишь с появлением тепла и света. Описание совершающегося два раза в год кочевья является составной частью развития сюжетов многих мифов, сказок, ярабц и сюдбабц (эпических песен), позднее стало традицией и в литературных произведениях. 
Упряжка из четырех оленей использовалась ненцами в жизненно важные, судьбоносные моменты, например во время сватовства. Из легенды «Нохо - силач» о том, как боролись между собой два претендента на руку девушки, с разрешения ее отца, читатель узнает, что проигравший приехал на упряжке из четырех пестрых оленей. Огорченный неудачей, оленевод предлагает победителю взять эту упряжку себе.

Темы сватовства и празднования свадьбы в прозе ненцев традиционно развиваются с участием мистической тетрады.

Число четыре в поэзии нередко становится символом начала новой жизни. У лирического героя стихотворения Лапцуя «Первый день солнца» появляется неудержимое желание новых дел, событий весной, открывающей временной цикл. В этот период возрождения активности соучаствует тетрада: герой сам «четверку оленей запряг», чтобы они стремительным шагом помчались в неоглядную даль тундры.

\section{Семь. Семерка}

В миросозерцании ненцев число семь играет «космическую» роль, оно тесно связано с представлениями об устройстве Космоса. Миф «Я Миня» начинается словами: «Когда не было ни земли, ни воды, высоко, на седьмом небе, жил Нум с братьями». Братьев было семь, после ухода отца они поделили владения. «Нум взял себе небо, братья разделили между собой звезды, луну и солнце. С тех пор стали они жить раздельно, но подчинялись Нуму. Только один из семи братьев не мог найти себе дела. Это был Нга. Его отправили в нижний мир, где тоже было семь ярусов. Для Нума братья нашли невесту, которая жила далеко, за семью небесами, ее звали Я Миня. Нум женился на ней, и она родила ему семерых детей. В подарок Я Мине отдал Нум землю со всеми живущими.

Герои повести Неркаги «Илир» в трудные моменты нередко обращаются к Я Мине, именно с ней они наиболее откровенны. Мысленные разговоры - прием раскрытия внутреннего мира героев-интравертов, постижения их тайных замыслов, нравственных установок - нередко используется ненецкими творцами.

Семерка у ненцев, как и у других народов Севера, пользуется особым почитанием еще и потому, что на небе северного полушария круглый год видны семь звезд Большой Медведицы, которые наполнены в их мировидении целым рядом значений и 
наделены сакральностью. В повести В. Ледкова «Синева в аркане» герой объясняет приезжей фольклористке, что созвездие Большая Медведица является часами для ненцев. «Ковш рукояткой смотрит сейчас в сторону заката, на запад. Потом эта рукоятка медленно опустится и покажет полночь. К утру Большая Медведица поднимется справа от Полярной звезды, ковш опрокинется и покажет тремя звездами рукоятки на восход. Тогда и взметнется над тундрой рассвет, и звезды покинут небо».

Число семь, воспринимавшееся ненцами как загадочное и сакральное, постоянно использовалось ненцами в ритуалах. Литературные герои-шаманы предваряют свое камлание: «Жители семи небес, где вы?»; «О, дети семи небес, придите!»; «О, Семирогий Олень, приди ко мне!»

В повести В. Ледкова «Синева в аркане» старик Явтысый узнал, что приезжая фольклористка нарушила запрет и побывала вопреки предупреждению на священной горе жертвоприношений, куда женщинам вход запрещен, решил отомстить за оскорбление богов. Предупредивший намеченную расправу оленевод рассказывает фольклористке и сопровождающему ее герою: «...ждал дня мести. Я знал, что он наступит на седьмые или семнадцатые сутки после оскорбления вами богов. Семь у нас, что в русских сказках “три”. Хотелось, конечно, чтобы наступил этот день на седьмые сутки, в вашем присутствии. Так и случилось». Старик изготовил кукол, символизирующих тени нарушителей, и решил их повесить на восходе солнца, что, по его мнению, принесло бы болезни или гибель этим реальным людям за несоблюдение законов тундры.

В стихотворении «Тундра - белый простор...» Василий Ледков называет родной край «чумом семи ветров»:

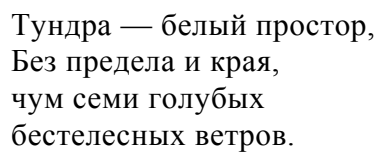

В представлениях ненцев бытовало мнение о семи разновидностях (по силе и направлению) ветров, которые вызывала мифическая птица Минлей, имевшая семь пар крыльев, образ которой нередко встречаем в литературе.

Для усиления дидактического воздействия стихотворения «Если ты по древним тропам...» Лапцуй сравнивает легкомысленного человека с постоянно меняющим направление и силу 
ветром, используя народные приметы, опирающиеся на значимость числа семь: «... у тебя ведь семь течений - семь различных направлений, как у ветра тундрового».

Красоту и многоцветие узоров, мастерство ненецких вышивальщиц подчеркивает Ледков в «Песне девушки» при поддержке метафоры с использованием семицветной радуги:

\author{
Вышивайся, что приснится, \\ Ясной радугой гори! \\ Будет у меня паница \\ Ровно в семь цветов зари.
}

Представленная Неркаги идеально организованная счастливая жизнь ненцев в прошлом в повести «Молчащий» ассоциирована с числом Семь. На Игралище, место традиционных праздников, «сходились люди Семи Земель, ехали издалека», «Великое солнце семь дней веселилось, глядя на Игралище».

Число семь участвует и в определении калыма за невесту в свадебном обряде. В романе «Месяц Малой Темноты» приехавшие свататься в чум невесты ведут переговоры с ее отцом, который иносказательно уточняет калым: «Только вот мне нехороший сон приснился: будто волки задрали моих пятнадцать оленей, а песец в семи капканах приваду съел и хвост показал». В ответ жених усмехнувшись, ответил: «Неверный твой сон. Оленей твоих не волки задрали, а просто они в мое стадо забрели. И не пятнадцать, а тридцать, а песец, сам знаешь, - житель ненадежный, вроде вольного ветра: за ним не уследишь. Может, и верно, песцы тебя обхитрили, так я тебе за семь непопавших десять дам: восемь простых и два голубых...»

Представляя читателю свою сакральную азбуку, Юрий Вэлла определяет «самое идеальное жертвоприношение - это 49 оленей (7x7)». Автор размышляет о жертвоприношении как значимом событии в жизни оленевода, во время которого тот задумывался над своим поведением, стремился, обращаясь к божествам, очистить себя от дурного. Вэлла усиливает значимость ритуала сообщением о слухах, согласно которым «после жертвоприношения человеку открывается любовь в наиболее чистых ее проявлениях».

«Азбука оленевода» является частью седьмого раздела книги Юрия Вэллы «Ветерок с озера» под названием «Автопортрет». В предисловии к этой книге А. В. Ващенко пишет о связи творчества Вэллы с фольклором и народными традициями, отмечает влияние «магических» цифр три и семь на построение книги. «Структурно автор тяготеет к тому, чтобы группировать свои 
сюжеты по магическим числам, на которых стоит народная традиция; у него это группы, кратные трем и семи. Книга состоит из семи разделов, и их порядок выявляет отчетливую логику. Все начинается с мелодии. Здесь лирический герой - он же повествователь - пытается постичь смысл прекрасного - и одновременно драму бытия. Вместе с тем мелодическая тональность, можно сказать, присуща всей книге» ${ }^{9}$. Уместно предположение, что исследователь связывает мелодику построения с семью основными нотными знаками.

В содержании рассказов-миниатюр Ю. Вэллы «полуфольклорного характера» (определение А. Ващенко) магия чисел три и семь существенно влияет на развитие сюжетов, на композиционное построение, на создание образов, на отражение национально-художественных традиций.

В мифах и фольклоре ненцев семь сыновей обеспечивают надежность существованию рода: «У Вая было семь сыновей», «У старика Сянко было десять тысяч оленей в стойбище. В чуме росли семеро сыновей». Герой романа В. Ледкова «Месяц Малой Темноты», будучи владельцем большого стада, в личной дорожной песне радуется не только своим успехам в оленеводстве, но и укреплению рода благодаря своим семи сыновьям. Тэси втайне от окружающих, которые могли бы осудить его за хвастовство, называет себя в песне «хозяином тундры»:

Он кедром могучим стоит на земле,

А корни оленьими тропами вьются

Уверенно тянутся к солнцу сыны -

Семь веток могучих Тэси.

Число семь символично связано автором с семью ветками Древа Жизни.

Семерка показывает храбрость и силу героев в ненецких мифах и фольклоре: «Переплыл семь бурных и огненных рек», «По дороге домой убил семь диких оленей».

В мировосприятии ненцев семь - это цифра везения. Так, подростку из эпической песни ярабц, убегающему от задумавших убить его братьев Пуци, помогает пурга, заметающая следы: «Семь дней и семь ночей шумит пурга. Руку протянешь - руки не видно». В поэме-сказке «Тёр» семицветная радуга стала символом спасения: «Расцвел небосвод семицветной дугой // И обнял неведомый берег».

Издревле у разных народов «семеричность» мира проявлялась в делении возрастов человеческой жизни: первый период - мла- 
денчество - длился до 8 лет, второй - отрочество - до 15 лет, юношество - до 22 лет, далее по 7 лет определялось молодому человеку, мужчине и пожилому мужчине. Юрий Вэлла в триптихе «Определители возраста» размышляет об этапах человеческой жизни, выделяя каждому из них по семь лет, как о периодах достижений в освоении важных для северного жителя, в первую очередь оленевода, умений, свершений, успехов в деле продолжения рода. Среди подмеченных у народа и выделенных Вэллой признаков достижения того или иного возраста много необычных, порой не совсем понятных представителям других культур: «Достичь возраста Белого Шва...»; «Достичь возраста Своей Походки (Своей Песни)»; «Достичь возраста мудрости иносказаний...»

Своеобразное восприятие ненцами семилетних периодов в жизни нашло отражение у большинства ненецких творцов. Цифры семь и семьдесят участвуют, например, в описании жизни и характеров героинь в повести зачинателя ненецкой литературы Николая Вылки «Марья». Героиню повести Вылки окружающие и автор в шутку называют «семилетняя бабушка», не объясняя причину. Раскрыть ее удается читателю благодаря общению девочки с бабушкой, которой семьдесят лет. Именно при наступлении этого возраста женщине-матери Пыя Нырки невестка предложила больше не работать (не участвовать в установке чума, не заботиться о еде и одежде мужчин...), а гулять с внучкой. И послушная внучка перенимает опыт, подражая бабушке, копируя ее действия. Именно за это девочку в шутку называют «семилетней бабушкой». Число семь символизирует в повести завершение предыдущего жизненного периода и вступление в иной, новый по своим задачам.

Завершив свой семилетний период жизни с матерью, оставшись сиротой, восьмилетний герой повести Неркаги «Илир» вступил в сознательное противостояние с хозяином стойбища Маймой. Тот возненавидел его еще при жизни матери за то, что рос Илир здоровым, сильным и умелым, в отличие от его сына. Любопытно, что с начала сиротства возраст мальчика больше не уточняется автором. Он как бы застыл, возможно, потому, что вступление с восьми лет в новый период семилетия уже не требовало выделения каждого года. Наступивший возрастной промежуток стал для Илира временем нечеловеческих испытаний и страданий, становлением иной жизненной позиции героя.

Литература ненцев, опираясь на мифопоэтические представления народа о числовой символике, с одной стороны, обогати- 
лась поэтикой иносказания, глубинными знаниями, а с другой приблизила читателей к пониманию мировидения героев.

Проведенный анализ художественного значения и функций чисел как повествовательных элементов в фольклоре и литературных произведениях ненцев способствовал решению вопросов их литературной истории, а также раскрытию традиционных представлений ненцев о мире и человеке.

${ }^{1}$ Блок А. Собрание сочинений: В 6-ти т. Том 6. М.-Л., 1962. С. 161162.

2 Топоров В. Н. О числовых моделях в архаичных текстах // Структура текста. М., 1980. С. 3-58.

${ }^{3}$ Кастрен Матиас, Александр. Путешествие по Лапландии, северной России и Сибири (1838-1844, 1845-1849) // Собрание старых и новых путешествий. Часть 11. М., 1860.

${ }^{4}$ Хомич Л. В. Проблемы этногенеза и этнической истории ненцев. Л., 1976.

${ }^{5}$ Юнг К. Г. Проблема души нашего времени. Пер. с нем. М.: Прогресс, 2006. C. 159.

${ }^{6}$ Там же. С. 160.

${ }^{7}$ Бахтин М. М. Автор и герой: К философским основам гуманитарных наук. СПб.: Азбука, 2000. С. 112.

${ }^{8}$ Юнг К. К феноменологии духа в сказке // Культурология. ХХ век. Антология. М., 1995. С. 354.

${ }^{9}$ Ващенко А. В. Живун (слово о Юрии Вэлле и его книге) // Вэлла Ю. Ветерок с озера. Ханты-Мансийск, 2008. С. 8. 


\section{Глава 5}

\section{МИФОПОЭТИКА И МИР ШАМАНОВ}

Шаманизм ненцев и других северных народов представляется религиозным явлением, тесно переплетающимся с мифологией, активно использующим мифологические представления и создающим новые мифы.

Осмысление мифологического миропонимания народов Севеpa, нашедшего отражение в их литературах, предполагает обращение к бытованию шаманизма. По мнению Мирче Элиаде, арктические народы, в отличие от многих других, хотя и ощутили влияние извне, не утратили после этого собственной структуры шаманизма и сохранили термин шаманизм «в строгом смысле» ${ }^{1}$.

Художественная семантика произведений ненецких поэтов и прозаиков пронизана шаманизмом как особой системой мировоззрения, включающей в себя элементы рационального, иррационального и образного познания мира. Шаманизм нашел свое яркое отражение в формировании художественного сознания ненецких литераторов.

В пьесе драматурга Ивана Ного «Шаман», в поэме «Тёр» и стихах Леонида Лапцуя, в поэзии Прокопия Явтысыя, Алексея Пичкова, Ивана Юганпелика, в стихах Василия Ледкова и в его дилогии «Месяц Малой Темноты», в повестях Анны Неркаги «Анико из рода Ного», «Илир», «Белый ягель», «Молчащий», в стихах и прозе Любови Ненянг, в произведениях других авторов представлены как шаманские образы, так и мировоззренческие установки героев и нарраторов, возникшие под влиянием идей шаманизма.

Шаманский универсум руководствуется своеобразной концепцией пространства и времени, действует в сфере альтернативных состояний сознания, используя внутренние приемы тренировки психики и трансформации энергетического и психического про- 
цессов. Он недостаточно изучен, чтобы мы могли обоснованно объяснять трансперсональные техники и ритуалы шаманских действий и результатов. Обращение к художественной литературе как источнику знаний о шаманизме - один из путей осуществления научных подходов к проблеме постижения специфики возникновения и развития этой религии у ненцев, формирования и функционирования дописьменного сознания, замкнутого, ограниченного из-за отсутствия внешних связей с другими культурами.

Ненецкая литература позволяет обрести контакт с феноменальным миром, обнаружить присутствие более древнего мировосприятия, познакомиться с миропониманием, символами веры донаучной эпохи.

\section{Культ духа}

В формировании картины мира ненцев возникшие первоначально культ духа и мистицизм, а позднее - шаманизм, впитавший в себя первородные два воззрения, явились устойчивыми формами постижения явлений природы, поскольку жизнь северян обусловливалась силами природы, проявляющими свое превосходство в жестоком и суровом виде. Для спасения себя, семьи и рода от могущественных, но неопределенных сил необходимо было найти противодействие. Подчинить себе неземные силы, расположить их к деятельной помощи, вероятно, и было одной из задач зачаточного состояния шаманизма.

Витальность рода Ного, например, по мнению Себеруя, главного героя повести Анны Неркаги «Анико из рода Ного», поддерживается с помощью передаваемого из поколения в поколение деревянного идола. Силой духа предков живы и лирические герои стихов Прокопия Явтысыя, Леонида Лапцуя, Василия Ледкова. Так, цикл стихотворений Прокопия Явтысыя «Вечная связь» посвящен раскрытию тайн постоянного и взаимозависимого контакта человека с духами предков. Лирический герой этих стихов ищет на своем теле знак, отметину, которая передана предками, уверен в том, что его судьба определяется, корректируется Духом предков, выделенным автором заглавной буквой. Герой утверждает: Дух этот «суров и неистов», он то «в яростном гневе ломает мной начатый путь», то «смягчает свой гнев и от смерти спасает», то напоминает, что «плохую выбрал дорогу».

Ведь выбор дороги всегда должен быть безупречен, 
чтоб род не позорить, всех тех - на ином берегу...

П. Явтысый устами героя признается в том, что когда однажды «дрожащей тропинкою лунного света» к нему спустились духи предков, он «ждал - наказанья, наказа, совета - за все, что при солнце творил, при луне». Под их молчаливыми взглядами он покаялся во всех даже небольших прегрешениях, и духи «исчезли, растаяли, словно туман», не проявив своего осуждения. После этого ночного визита, когда к нему прикоснулась «рука Запредела», он стал верить, что таинственный, хрупкий мир духов наблюдает за ним и «доверие Духов - как стержень» споспешествует преодолению преград. Связь с предками, по мнению поэта, постоянна, определяет жизненные дороги ненца. Духи предков способствуют витальности, подпитке энергией.

У ненцев, как и у других коренных малочисленных народов Севера, в фольклоре и литературе ярко обозначено убеждение, что душа или дух (как порой они ее называют) после отделения от тела может жить лишь при соблюдении определенных условий, и прежде всего при условии попечения, заботы о ней живых людей. Только душе, ставшей предметом заботы земных жителей, обеспечено дальнейшее существование. Эта забота о душе умершего, вероятно, постепенно стала общепризнанным культом на одной из начальных ступеней развития сознания.

Позднее культ перекочевал в религию, поскольку именно культ духа - первооснова шаманизма. В развитии религиозного сознания этнологи XIX - начала XX вв. Шурц Г. (немецкий) и Липперт Ю. (австрийский) усматривали два аспекта: «мы можем говорить о культе, коль скоро человек просто обращается с просьбой или жертвенными дарами к высшим силам, чтобы снискать их милость, помощь; напротив, мы можем называть мистикой веру человека в то, что в нем самом есть нечто неземное, способное познавать высшие силы, его стремление эту таинственную, бессознательную внутреннюю жизнь использовать для своего сознания и этим путем подчинить себе и другие сверхъестественные силы» ${ }^{2}$.

По утверждению как названных выше этнологов, так и некоторых других ученых, например, М. А. Кастрена, В. Г. Богораз-Тана, все высшие формы религии создавались из культа, мистики и мифологии, соединенных в одно целое. На ранних ступенях и в зачаточных религиях, к которым относится шаманизм, первичные явления часто появлялись независимо одно от другого. 
Лишь ощущаемая человеком внутренняя связь с духом или контакты с миром духов, позиционируемые в обществе, и были изначально религией.

Как развивался культ духа? Вероятно, первоначально в сознании появилось разделение между телом и духом как признаком жизни.

Убеждение же, что душа (или дух), покидая тело, не исчезает, а существует в невидимом состоянии, накладывало обязанности заботы о ней для поддержки ее в ином состоянии. Попечение, забота живых людей о душе умершего и стала культом на начальной ступени развития. Эти некие духовные существа, вероятно, способны воздействовать психологически, проявлять свою силу, могут действовать дружески или враждебно. Позднее человек уже воображал, что за явлениями, не имеющими никакой видимой причины, скрываются существа, совершенно неизвестные ему и лишь сходные с душами умерших. Предположительно, выражавшееся в культе чувство обязательства и вытекавшее из выполнения последнего притязание на содействие и помощь и формировали начальную конфигурацию религиозного сознания.

Истоки культа духов - попытка осознания себя в мире и поиск ответа на вопросы: Что есть жизнь? Какие условия создают и продляют ее? Отсюда вытекает и значение культа духов как архетипа, обусловившего его роль в развитии менталитета, в укреплении жизненных сил вообще.

Прокопий Явтысый в своих стихах, уподобляясь шаману, с помощью духов пытается связать срединного человека со звездным небесным миром и с подземным миром, с предками, предсказывающими будущее. «Мы - их жизней продолженье. / Потому-то вместе с нами /Духи Предков - от рожденья / Явью в нас живут и снами». Поэт с помощью выполненной им самим ассоциативной графики, иллюстрирующей книгу «Взойдет росток души» (Нарьян-Мар, 1996), представляет читателям облик являющихся ему во сне и наяву духов. Подписи к рисункам строки из его стихотворений: «Дух, улетающий на рассвете», «...рука Запредела ко мне прикасалась, - доверие духов - как стержень во мне», «Мать-Земля». На этих рисунках изображены экспрессивные существа, порой лишь отдаленно напоминающие человеческий облик, близкие фантазиям Гойи.

В повести Анны Неркаги «Анико из рода Ного» благодаря умению автора передать мировоззренческие установки, среди которых существенное место принадлежит культу духов, мистике 
и шаманизму, раскрыт внутренний мир героев, представлена картина национального видения жизни во всей ее многозначности и многокрасочности. Сюжет повести построен на описании значительно отличающихся вариантов видения мира, на их столкновении, отторжении и попытках взаимопонимания. Главные герои повести - отец и дочь. Их видение мира обусловлено разными культурными влияниями. Оленевод Себеруй внутренне связан с духами, визуализирующими их идолами, атрибутами ритуалов шаманизма. Особым предметом его жизненной заботы стало сохранение главного для него идола - Хранителя рода Ного, его Хозяина. Все члены рода приносили ему жертвы в добрые и плохие времена. Сохранение его ассоциировалось прежде всего с выживанием рода, поэтому Себеруй как святыню бережет «маленького человечка в белоснежной малице».

Его дочь Анико с малых лет училась и жила в школеинтернате, не бывая даже летней порой в стойбище родителей из-за отдаленности школы от поселка. Потом девушка поступила в институт в Тюмени. И вот теперь она в связи со смертью матери приезжает к отцу. Ей непонятны живущие в стойбище оленеводы, их быт и традиции. Анико отказывается остаться с отцом и заниматься оленеводством, чтобы «продолжать род», стать верной извечным обычаям, которые стали ей чужды. В поисках оправдания своего поступка, не желая огорчать одинокого стареющего родителя, Анико дает ему надежду, что когда-нибудь вернется в стойбище. И тогда Себеруй принимает непростое для него решение - позволить дочери взять идола, покровителя рода Ного, с собой, увести в чужой мир.

Безраздельное поклонение, искренняя вера отца в силу деревянной скульптурки невольно передаются дочери. Она выполняет просьбу Себеруя встать на колени перед идолом и попросить его как хозяина рода быть добрым к ней. Девушка пообещала отцу не бояться сакрального деревянного образа, а надеяться на его мудрость и ответственность не только за нее, но и за ее будущего мужа.

В атеистическое сознание Анико неожиданно «пробивается» вера предков. Закрыв глаза, она вдруг ощущает, что от идола исходит некая сила и, возможно, от него действительно может зависеть и ее судьба, и судьба ее детей и всего рода Ного. В этот миг она как бы прозревает, проникается неожиданной любовью к жизни, к отцу, к земле предков. Девушка «взяла Идола и несколько минут стояла неподвижно, понимая, что приняла сейчас 
душу отца, матери, деда и всех, кто жил на земле до нее. Не Идола отец передал ей, а право, святой долг жить на родной земле и быть человеком».

Передав атеистке Анико, последней из рода Ного, главного Идола, Себеруй наказывает ей беречь его как судьбоносное существо. У него укрепилась вера в возможность продолжения жизни рода. Здесь возможно нашла отражение и другая мировоззренческая установка, свойственная больше тотемизму - искать убежище для собственной души, прятать ее в тотеме, другом человеке или в символе рода - идоле.

В повести раскрыта таинственная роль в жизни ненцев разного типа идолов, в том числе тех, которые обеспечивают поддержку воли человека к жизни, спасают от одиночества. Фигурки-портреты погибших жены и дочери изготовил и посадил на шкуру олененка Себеруй. По размерам и одежде они соответствовали умершим: «Идолов два, один ростом с ладонь. Судя по одежде - женщина. На голове платок из кусочка красной материи, на шее ожерелье из бусинок, колечек, старых монет, ягушка (меховая женская одежда) на ней очень красивая. Это Некочи. Второй Идол совсем маленький, его едва заметно под малицей. Себеруй поставил перед идолами небольшой столик. У ненцев так: не я хожу к столу, а он ко мне. Налил в тарелки супа, одна из них, маленькая, видимо принадлежит Идоленку. Рядом с тарелками положил по куску хлеба». Оставшись один, Себеруй с помощью скульптурных изображений своих ушедших в иной мир родственников создает мир семьи, спасаясь таким образом от тягостного одиночества.

Выпадавшие на долю рода несчастья ненцы относили на счет могущества злых идолов, которые порой, согласно сказкам, побеждают в битве за людей с добрыми идолами. Герои повести все важные события в жизни объясняют для себя и окружающих воздействием добрых или злых духов, поселившихся в сакральных фигурках: «Идолы подарили ей четырех сыновей»; «Пусть идол Жизни поможет Себерую», - желают мысленно жители стойбища.

Искреннюю веру в силу духов, «очеловечивание» их, изготовление идолов как символов этих духов некоторые этнологи, исследователи мира шаманских образов, связывают с наличием некоей энергетической связи между человеком и идолом. «Изваяния духов представляются нам своего рода узлом энергетических каналов, по которым циркулирует космическая субстанция. Такая точка зрения коррелирует с их космологическими и, 
соответственно, космографическими представлениями о тропах духов, пересекающих их местность» ${ }^{3}$. Как уже отмечалось, по мнению исследователей культуры северных народов России М. А. Кастрена и В. Г. Богораз-Тана, искусство волшебства, магия, заклинания представляют более раннюю культурную стадию, чем вера в богов. И хотя впоследствии вера в богов позаимствовала из магии те или иные элементы, из веры в богов нельзя объяснить происхождение магии.

В качестве оберега ненцы использовали, например, окружение своего пространства кругами, которые делали или с помощью ремней или просто обходили, создавая непреодолимое препятствие для злых духов. В поэме «Тёр» главный герой эффективно использует круг в качестве оберега, заговора от врагов. Вспомнив совет Трехкосой, он «по-хозяйски приказал / Головному другу, / Чтобы тропку проторил / Без узды по кругу». Так была изолирована «рать врага, как петлей аркана». Тёр создал с помощью заговора препятствие для врагов, которые не могли покинуть очерченный круг.

Магия в своем возникновении стремилась не только к познанию мира, она как бы выражала протест человека против ига природы и стремилась победить самовластие ее не только активными телодвижениями и непонятными словами, но и усилиями собственной воли. По мнению Кастрена, шаман сам стремился стать господином природы и духов-помощников избирал себе тоже сам. У фольклориста и лингвиста было отчетливое понимание того, что на самой ранней первобытной стадии материальные изображения представляли собой не символ, не место обитания, не воплощение богов или духов, а являлись сами по себе живыми и могущественными в своей первичной форме. Действительно, у героев ненецкой литературы деревянные фигурки сами съедают жир, которым мажут их рот. Это указание на активность магии, на наличие волевого элемента, на стремление к борьбе с природой, а в дальнейшем и с духами, представляет очевидный противовес позднейшему учению об анимизме, где человек изображается пассивным перед властью могущественных духов, приходит на помощь к избранникам, давая им шаманскую силу.

Из века в век собирали в священный ящик семейных идолов оленеводы рода Окотэтто в повести А. Неркаги «Илир», держали и возили их с собой на священной нарте. Все верили, что «их глаза и умы, по словам старых людей, следят за тем, что происходит в трех мирах: на небе, на земле и под ней». 
Домашних духов, хэхэ, ненцы хранили в чистой части чума, а при перекочевках перевозили на специально предназначенных для этой цели нартах. У обрядовых нарт были семь пар копыльев и семь отметин на полозьях. Священные нарты покрывали оленьей шкурой с головою и ногами, и даже с копытами. На нарты иногда клали ящик с крышкой для идолов. На переднюю поперечину вешали различные железные подвески, кусочки сукна.

Вся нарта представлялась как бы живым существом. Верхние продольные перекладины имели зарубки, изображающие спинную кость духа, вселившегося в нарту. Передняя часть ее считалась головой и намазывалась жиром и кровью, что означало кормление духа. Копылья считались ногами.

Твердая вера в поддержку идолами жизни рода, в их силу и в то, что они подобно людям видят и слышат, заставляла тщательно заботиться о них. Герой повести Анны Неркаги оленевод Мерча, старший рода Окотетто, каждое лето менял «любовно выделанную шкуру олененка» на священном ящике, а старую шкуру сжигал, «чтобы не оскорбить идолов, случайно испачкав то, что прикрывало их». В руки идолов брал редко, «опять же боясь оскорбить покровителей», и «только для того, чтобы намазать их первыми каплями крови жертвенного оленя, отдать им лучшие кусочки оленьего языка, печени, костного мозга».

Чувство гордости и достоинство не позволяли ненцам искать заступничества и покровительства высших сил всуе, без особой нужды. Склоняли перед идолами головы только в исключительных случаях, когда был нужен совет и заступничество. Если же не получали желаемого, могли сурово расправиться с ними. Так, Майма (повесть «Илир»), наследник священного семейного ящика с идолами рода Окотетто, не может смириться с тем, что теряет свое большое стадо, а с ним и власть, поэтому вершит в своей жадности и злости один за другим жестокие поступки по отношению к окружающим его людям. Он не осознает своих прегрешений, не видит, не хочет видеть и понять страданий других. Всю вину за разваливающийся выстроенный им в мечтах порядок Майма возлагает на безмолвных идолов. И в порыве неуемного гнева, не найдя на лицах идолов из священного ящика желанной для него боли и сострадания, Майма выбрасывает всех накопленных веками защитников рода, мстит им за отсутствие поддержки жестокими ударами, отрекается от них. Злоба и ненависть Маймы столь велики, что даже фигурка его личного покровителя лишь на миг вызывает теплые воспоминания, но и ее он «наказывает» пинками. 
Выбросив идолов, Майма не может полностью избавиться от их воздействия, сознание периодически возвращает его к их «душам». Теперь он считает, что оскорбленные идолы прокляли его чум, наслав смерть на сына и его мать, на отца Маймы, который умер вдали от родного кочевья, приняв на себя вину за убийство, совершенное Маймой. Однажды, глядя на огонь, среди теней он увидел фигурку старичка-покровителя, которого наказал, пнув в лицо. Оленевода испугало видение: глаза идола открылись и смотрели на него глазами убитого им Сэротэтто, а по щеке текла кровь. Собрав все силы, он заставил жену «оживить огонь», чтобы избавиться от теней, которые от пламени новых веток «нехотя стронулись с мест и уползли». В тенях огня, появлявшихся на закопченых шестах, ненцы видели духов или душ идолов, боялись, что они могут проклясть чум.

Поведение Маймы, расправившегося с сакральной нартой и ее обитателями, свидетельствует о попытке освобождения от мистических сил, от влияния коллективного бессознательного. Отделение себя от мира - начало индивидуальной дифференциации в сознании, естественно, способствовало избавлению от страха. Однако независимость внутреннего мира оплачивалась конфликтом сознательного и бессознательного. Человек создавал внутри себя пространство внутренней свободы, вырабатывал сознательные концепции мышления. На примере Маймы можно проследить, как в нем появилось желание увеличить расстояние внутри собственной души, преодолевая самого себя, чтобы избавиться от страха. Освободившись же от него, решительный Майма, к сожалению, поддается влиянию собственной агрессии, теряет человеческий облик в отношении с окружающими, проявляет беспредельную жестокость по отношению к сироте Илиру. Будучи уверенным в безнаказанности, Майма заставляет мальчика выполнять обязанности собаки, за которую тот заступился, вынуждает глодать кости после пса, избивает его, а потом запрещает ему говорить. Майма движим желанием не только отомстить мальчику за то, что тот рассказал, где находится спрятанная часть оленьего стада, но и выместить на нем злобу за все жизненные неудачи. Поднявшаяся из недр души агрессивность заслоняет все доброе, что иногда проявлялось у Маймы, побуждает нарушать закон тундры, обязывающий заботиться о сиротах, забыть о возможности покаяния перед идолом, который обычно охранял чум, удерживал от безнравственных поступков. Деревянные, каменные или изготовленные из меха и ткани изображения 
зооморфного или антропоморфного характера ненцы держали в передней части чума напротив входа, поскольку она считалась чистой. Там антропоморфные изображения и камни одевали в меховую или суконную одежду национального покроя. В зависимости от функций этих изображений одежда была мужской или женской. Часто на одну фигурку надевали по несколько одежд одна на другую, поскольку часто новую одежду шили в благодарность за оказанную помощь.

Среди домашних хэхэ, добрых духов, особо почиталась покровительница семьи (хозяйка чума) Мяд-пухуча. Она раньше присутствовала в каждом чуме и находилась в женской половине, обычно на подушке старшей женщины или в сумке над ее изголовьем. На ней нередко оказывалось очень много одежды. При заболевании ее клали в изголовье больного. Чтобы узнать об исходе болезни, ее брали на руки и взвешивали: если фигурка оказывалась легкой, то больной должен выздороветь. В повести «Илир» хранительницу очага Мяд-пухучу, защитницу чума, Майма попросил старшую жену спрятать, когда увидел, что к чуму приближаются незнакомые люди. К Мяд-пухуче ненцы обращались гораздо чаще, чем к духам из священного ящика, поскольку этому идолу можно было покаяться в мелких грехах, попросить помощи в каком-либо семейном деле, разрешить сиюминутный вопрос.

Больного растирали камнем хэхэ или кололи носом в больное место. За помощь забивали оленя и мазали рот хэхэ теплой кровью. Иногда в благодарность шили новую одежду, дарили ему медяшки, цепочки.

Хэхэ, помогающему на промыслах, жертвовали лапы и носы добытых животных.

Прокопий Явтысый в стихотворении «Было все необычайно...» сталкивает разные мнения о значимости идолов, о шаманизме, которые существовали у ненецкого народа. Герои конца $\mathrm{XX}$ века, именуемые во множественном числе - «мы», рассматривают случайно обнаруженного идола, вспоминают о его значимости в прошлом, когда пастух мог просить сакральную фигурку о помощи, а потом благодарить ее или наказывать: «За удачу мазал салом, / За беду - лупил ремнем!» Немало пережил идол вместе с его кочующими хозяевами. Он был атрибутом во время камлания: «И шаман над ним бил в бубен, /Духов Предков призывал!». В более близкое и знакомое для героев стихотворения атеистическое время, когда вера в духов стала атавизмом, идол «осиротел». И вот теперь, в новейшие времена, «случилось чудо 
вдруг - идол вновь в тот вешний вечер встретил ласку теплых рук!» Так, Явтысый вписал в содержание стихотворения социальные перемены, изменение отношения к шаманизму.

Во время камлания идолов брали из священных нарт, расставляли на оленьих шкурах лицом к солнцу. С хэхэ нередко в мифах и фольклоре связывалось оборотничество. Герои мифов и сказок становятся «хэхэ» и превращаются в разных зверей, которых в одном из мифов, например, названо двадцать четыре (собаки, волки, росомахи, медведи и др.), рыб (налим, язь, ерш и др.). С духами была связана и установка на уничтожение всего оставшегося на бывшем месте стоянки: его сжигали, чтобы дух мядинда, посещавший чумовище сразу после откочевки людей, не мог причинить вред уехавшим через оставшиеся предметы (особенно опасными были волосы и остриженные ногти).

На мужском поясе прикреплялся сзади медвежий клык, который служил оберегом от злых духов и приносил удачу в охоте, а также предохранял от болезней.

Идолов использовали и для проклятий. Старшая жена Маймы (повесть «Илир») яростно выражает свой гнев: «О, идолы! Добрые и злые! Помогите мне... Пусть лицо молодой жены почернеет, как железо, на котором горит огонь, а тело ее пусть разорвут собаки...»

Мистическим существом - хэхэ - становились отдельные герои в мифах, сказках, эпосе и литературе ненцев, когда им предстояло передвижение в пространственных рамках «земля-небо» и обратно. И это не казалось ни сказителям, ни писателям чем-то сверхъестественным, так подчеркивалась избранность героев.

Магическое мировоззрение ненцев опиралось на идею глубочайшей связи человека и его земли, органической связи с космосом. В гносеологии (понимании) шаманизма человек - микрокосм. Следовательно, он так же многосложен и многосоставен, как и макрокосм. Он представляет собой малую цельную вселенную. Являясь микрокосмом, человек невидимыми сакральными нитями связан с макрокосмом. Герои ненецкой литературы нередко ощущают таинственный контакт с космическим пространством.

Стихотворение Прокопия Явтысыя «Ненецкая баллада» наполнено мистическим восприятием утренней зари, которая представлялась ненцам не только предвестницей нового цикла суток и, следовательно, носительницей добра, но и провозвестницей будущего человека. Поэт, раздумывая о трудности и быстротеч- 
ности человеческой жизни, находит общее в судьбе вынужденного периодически покидать землю солнца и человека:

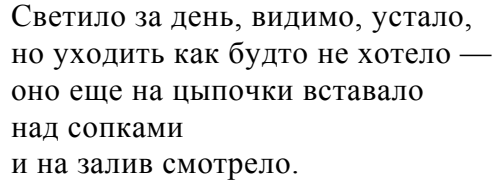

Василий Ледков в стихотворении «Звезда голубого огня»так называли ненцы Полярную звезду - выразительно предъявил одно из самых магических небесных светил. По цветовым оттенкам этой звезды определяли предстоящие ненастья и невзгоды, которые, по их мнению, насылал разгневанный Нум бог небес. Так, синева путеводной звезды приводила в отчаяние:
Прадед мой забивался в чум,
Выли женщины, побледнев:
«В небе сердится страшный Нум,
И в глазу его - синий гнев!»

То, что жилище остывало по ночам, тоже связывали с влиянием Полярной звезды, с ее действием:

Голубая звезда тепло

По ночам из чумов сосет.

Вместе с тем, этой звезде посвящено ряд стихотворений, воспевающих красоту ее и способность быть путеводной в кризисных ситуациях. Для шамана же Полярная звезда символизировала связь с верхним миром, возможность с ее помощью проложить путь на небо, выстроить мировую ось, по которой он якобы может подняться в верхний мир.

Мистические представления ненцев о таинственной мощи природных явлений, а также вера в то, что действия человека могут вызвать их бурную реакцию, нашли отражение в стихах Алексея Пичкова. В стихотворении «Я хотел бы солнце заарканить...» поэт уверяет: «Где-то на озерах лебедь ранен, /Оттого кровавится закат». Смысл стихотворения основан на осуждении охотника, подстрелившего лебедя. Лебедь в коллективном сознании ненцев наделен сродством с человеком и правами защиты. Автор подчеркивает магическую силу лебедя, связывает его гибель с появлением кровавого заката, предвещающего непогоду. Мистическим восприятием природы навеяны метафоры в другом стихотворении А. Пичкова «Льдинки звенят на ветру...»: «ночь 
черно-бурой крадется лисицей»; «Как светлые копья, / Дрожат на морозе / У дальней звезды золотые ресницы».

Восприятие природного мира у ненцев овеяно легендами, которые легли в основу композиции многих произведений ненецких литераторов. В повести «Илир» А. Неркаги, например, задающей развитие сюжета и смыслоопределяющей поведение главного героя является легенда о голубых великанах-скалах, которые помогали, «если стоял перед ними человек не злой и не хитрый».

Культ гор, имеющий длительную историю, сложился, вероятно, на основе синтеза дошаманских воззрений, относящихся к культу родоплеменных святынь, позднее - к культу шаманских духов-покровителей. В кризисный момент своей беспросветной тяжкой жизни восьмилетний Илир вспоминает рассказанную матерью жизнеутверждающую легенду о голубых скалах. Это миф о великанах, которые жили в их краю, «всегда освещенном солнцем». О том, когда было это время, не помнят «даже самые древние ненцы». В те времена чумы были покрыты цветами и травами, усыпаны ягодами, а великаны вели жизнь красивую, полную добра и справедливости, их мужчины охотились, а женщины растили детей. Великаны не умели злиться и плакать, они улыбками избавляли окружающих от грусти и болезней. Они были воплощением мечты о счастливых людях, которые являлись еще и символом космического единства, своеобразным «древом жизни», соединяющим небо и землю, так как были столь высоки, что «доставали рукой до неба и по утрам обтирались прохладными чистыми облаками».

Гармонию и идиллию жизни великанов, согласно легенде, нарушили враждебно настроенные «маленькие юркие человечки со злыми лицами», которые убили одного из великанов. Задумавшись о том, как победить врагов, оживить сородича, великаны соединили плечи, «от тяжести мыслей» затвердели и превратились в скалы. И только их сердца «остались живыми». Голубой свет одного из сердец увидел в расщелине охотник и рассказал об этом людям.

Наполненный впечатлениями от услышанной легенды, маленький герой повести Илир с надеждой и радостью всматривается в вершины скал, верит в их защиту и помощь. В этих же скалах прячет свое стадо его жестокосердный хозяин, превративший мальчика в подобие пса, запретивший ему разговаривать и избивавший беззащитного сироту. Развязка повести - свидетельство благожелательного отношения, проявления защитной силы скал к сироте Илиру и мщения кощунствующему Майме за его садизм. 
Это убедительное художественное подтверждение действия извечного закона нравственности: добро побеждает зло. Илир резонирующими в ущелье криками направляет оленье стадо на хозяина, и олени в страхе неумолимо и грозно несутся на удивленного их непослушанием оленевода. «Именем голубых великанов мальчик гнал стадо на хозяина, освобождая Землю от зла, а свою душу от нелюбви к жизни». Достижение победы добра над злом стало возможным лишь путем борьбы. Долгие страдания и размышления способны парализовать волю, вызвать неприятие жизни аксиома, особо значимая для поддержания витальности, о которой должен помнить человек, попавший в сложные обстоятельства или потерявший надежду на исполнение мечты.

Одухотворение стихии воды отражено в стихотворении Л. Ненянг «На концерте», где героиня под звуки музыки уносится мыслью в просторы тундры, на берег разбуженного ледоходом Енисея. В сознании предстают картины «жизни» духов весенней порой, когда «кончилось время девичества у красавицы дочери Доброго Духа Воды», начался ледоход как пора оживления, предвещающая свадьбу, на которую надеется Старый Дух Океана, ожидающий речные набухшие льды.

На вере в умение птиц понимать язык человека, его чувства и переносить слова и мысли на дальнее расстояние построено стихотворение П. Явтысыя «Первая разлука». Неко, героиня стихотворения, обращается к кружащим над нею лебедям с просьбой найти в тундре любимого оленевода Хэло и поведать ему о тяжести разлуки и о плачущем сердце: «его найдите и расскажите, как мне тяжело». При этом себя героиня сравнивает с другой птицей - тундровым куликом, во-первых, потому, что голос этой птицы напоминает часто человеческий плач, а, во-вторых, понять просьбу лебеди смогут быстрее, если передаст ее другая птица.

Ненцы приписывали птицам таинственную силу и власть над стихиями. Среди атрибутов шамана почти всегда присутствовали перья птиц. Надевая их на голову, он надеялся приобщиться к зоркости, прозорливости и мудрости той или иной птицы. Использовались перья пернатых, которые, согласно мифам-сказкам, являются посредниками между тремя мирами: небесным, земным и подземным. Медиумная роль орла и волшебной семикрылой птицы минлей, их значимость в осуществлении связи трех миров раскрыты в ненецких мифах, сказках и литературных произведениях.

В сказке «Как могучий орел вернул ненцам солнце» представлена сначала райская жизнь ненцев при нескрывающемся с 
горизонта солнце. В то далекое и счастливое время в озерах и реках водилось много рыбы, оленьи стада паслись от берегов морей до самых лесов, голубые и белые песцы были всюду, птицы прилетали весной. Веселую жизнь, полную песен, испортил завистливый черный коршун, узнавший от прилетавших в ненецкий край ястребов о счастливой жизни. По воле жестокого завистника злые ястребы сетью поймали солнце и утащили в далекий край, угнали оленей, истребили песцов. Могучий орел со своими орлятами вступил в битву с коршуном и ястребами, освободил солнце, повесив его посреди неба, чтобы было светло и тепло всем, вернул ненцам радость и веселье. Орел в литературе ненцев представлен в образе могучего покровителя как мира птиц, так и людей. Трагична картина гибели могучего орла, открывающего повесть Анны Неркаги «Молчащий», в которой герои-скопийцы забыли свои традиции, обычаи, умение жить в гармонии с природой и погибли. Орел, убедившись в том, что остался в срединном мире один подобно капитану, покидающему гибнущее судно последним, расстается с жизнью.

\section{Мистика и эстетика жертвоприночения в литературе}

Художественное освоение мира ненецкими сказителями и литераторами осуществлялось в прямой связи с мифопоэтическим мышлением народа, в котором значительна была роль шаманизма, представления о триединстве окружающего. Ненец на связь с небесным локусом и подземным миром выходил не только при поддержке домашних идолов или «природных хозяев», но и во время посещения сакральных мест жертвоприношений.

Жертвоприношение - «способ установления коммуникации между священным и светским мирами посредством жертвы» ${ }^{4}$. Жертвоприношение также относится к обычаям, в которых заложена цикличность мифопоэтического времени.

В существовавшей у ненцев системе жертвоприношений основную часть даров составляли черепа и рога оленей, повешенные на деревьях. На путях весенних и осенних перекочевок непременно присутствовали священные места для этого обряда. Они выполняли «пограничные» функции, и нельзя было перейти на другую территорию без предварительного жертвоприношения - очищения. Иерофании - объекты почитания, места проведения ритуала часто определялись особенностями ландшафта. 
В стихотворении «На сопке жертвоприношений» В. Ледков описал впечатления детства, когда он во время обряда пил вместе со всеми «оленью, чуть теплую кровь» и боялся ликов деревянных идолов. В семидесятые годы XX века автор видит на этом месте лишь оленьи головы с рогами и медвежий череп. Ухающая сова повергает автора в тоску, вновь нагоняет непонятный для атеиста страх.

Как свидетельствует художественная литература, щедрые подношения сопровождали кризисные ситуации, из которых ненцы пытались выйти с помощью обращения к духам. Себеруй (повесть «Анико из рода Ного») вспоминает, как во время эпидемии вымирали целые стойбища. В тот год оленеводы приносили богатые щедрые жертвы добрым Идолам, старейшины и шаманы неистово упрашивали добрых духов не трогать хотя бы детей. Но напрасно. Идолы каменно молчали, ничто не трогало их: ни слезы, ни стоны, ни мольбы. «Много тогда в тундре людей погибло, много крови выпили ненасытные Идолы. Болезнь поглотила род».

Почитая природный мир, ненцы устанавливали с ним доброжелательные отношения. Духи природного мира вместе с духами предков входили в число наиболее почитаемых. Анико (повесть «Анико из рода Ного») вспоминает, как в детстве отец ловил рыбу, угощая каменных идолов, лежащих на берегу озера, которые считались «хозяевами озер». Перед тем, как закинуть невод, он угощал их чем-нибудь вкусным, например, вареньем из морошки, а если улов был хороший, то разделывал самого большого сига для угощения духов воды. При малом улове Себеруй долго смотрел на идола, а потом говорил в качестве наказанья: «Ему сегодня ничего не надо» и не делился добытым. Природосообразность, отношение к природе как к живому существу, имеющему душу - духовный скреп культуры и одна из определяющих черт шаманизма. Магическая власть природы над человеком, поддержка своего вмещающего и кормящего ландшафта была частью мировоззрения, выработанного веками опыта бытия.

Природный мир представлялся ненцам реагирующим на поведение человека, способным стать соучастником его жизненных дел, принести удачу или неудачу, радость или горе, добро или зло. Своих духов-хозяев имели земля, реки, озера, отдельные урочища. Дух воды мог дать хороший улов, поэтому его задабривали жертвоприношением: после каждого удачного лова рыбы опускали какие-либо предметы прямо в воду. При переходе 
на новое место кочевья весной и осенью приносили в жертву не только какие-либо мелкие предметы, но и оленей, вывешивая их рога на ветки лиственницы.

В благодарность за рождение ребенка хозяин давил для хэхэ оленя и мазал идолов теплой кровью. Мясо оленя, принесенного в жертву, съедали, кости собирали и относили на защищенное от каждодневного бытования место, где бы их никто не мог топтать. Череп вместе с рогами увозили и оставляли на святилищах.

Хэхэ, устанавливаемые на священных местах, обычно не имели одежды. Это были в основном вытесанные из дерева фигурки с головой и ногами, но часто без рук. Эти антропоморфные изображения называли сядэи.

В повестях А. Неркаги, Л. Ненянг, романах В. Ледкова, стихах поэтов-ненцев можно не раз встретиться с упоминанием или описанием традиций жертвоприношения, которые совпадают с данными этнологов.

Рассказывая о священном месте в Большеземельской тундре в историко-этнографическом исследовании «Самоеды», Г. Старцев представил священную рощу, названную русскими «Казьмин перелесок». «Тадибеи всех самоедских тундр обязаны были для пензера или барабана вырубать дерево из сей только рощи. Кроме шаманских деревьев, использовавшихся для изготовления бубнов, в священной роще росли особые деревья - покровители (двойники) человека... Многие из простых самоедов имели обычай, вырубив из оной небольшую елку, возить в санках со своими идолами до конца жизни». Представление о сакральной отмеченности деревьев рощи «Казьмин перелесок» нашло отражение и в обрядовой практике ненцев, они использовали эти деревья в качестве «устройства» для жертвоприношений. Среди пород деревьев, отмеченных следами ритуальной практики, особо выделяется береза, за ней следует ель, бывают они и на осине и рябине. Определенный интерес представляет и топографическое распределение ритуальных деревьев на площади святилища. В южной части святилища жертвоприношения чаще всего располагались на ели, а в северной - на березе. Ведущей категорией жертвенного набора являлись разнообразные пояски, ленты, ремни, веревки, куски ткани. Вторым важным компонентом жертвенного комплекса являлись предметы, изготовленные из меди, бронзы (зеркало, колокольчики, кольца, перстни, бляшки). Третью категорию составляли человеческие изображения на дереве. По своему функциональному назначению священные деревья уподоб- 
лялись шаманскому дереву, которое моделировало структуру мироздания. Моделирующая функция связок-лент, поясков, ремней раскрывается и в их цветовой гамме (красные, белые, зеленые), которая имеет прямые соответствия в цветовых обозначениях модели мира ненцев. В ненецкой космологии белый цвет обозначает верхний мир; красный - срединный, земной; зеленый - нижний, подземный мир 5 .

Жертвоприношения сопровождались камланием шамана. Для жертвы выбирали «достойного» оленя, оленя-богатыря. Именно такого жертвенного оленя заарканили, проявляя хитрость, ловкость, сноровку и силу, сыновья богача Тэси в романе В. Ледкова «Месяц Малой Темноты». Автор подробно описал процесс жертвоприношения. Перед тем, как душить жертвенного менурея (вожака стада), Тэси в полной тишине трижды провел вокруг шеи оленя шкуркой горностая, встал на колени, протянул руки к солнцу и пробормотал заклятие. «Красавец олень рухнул на землю: душу его люди отдали богам».

Как жертвовали, задабривая духов перед началом сезонного промысла или в благодарность за хороший улов, за богатую добычу, а также за спасение, Ледков описывал многократно. Герои его романа «Люди Большой Медведицы» Вавля Лаптандер и Игна Сядэй во время охоты оказались на оторванной льдине. Когда к ним пришла помощь, мужчины не сговариваясь, решили оставить морского зайца духам моря, как выкуп за свои головы. Поскольку признаваться в своем решении перед спасшим их атеистом Петой они не хотели, то сделали вид, что забыли про добычу.

Много жертвенных мест, принадлежащих целому роду или отдельным семьям, кочевавшим в той или иной местности, располагалось возле камня какой-то особой формы, на вершине сопки, которая будто бы в разную погоду меняет свои очертания, на берегу озера. В восточной тундре часто на священном месте ставили лиственницу (светлое дерево).

Священными места признавались обычно по указанию шаманов. Он не только называл место, которое должно почитаться, но и уточнял, что именно здесь нужно поместить, а также считать в качестве хэхэ, т. е. определял хозяина данного священного места. Обычно шаман выбирал места, где происходили необычные явления: кто-нибудь испугался, провалился под лед, утонул и др.

Можно предположить, что причиной неадекватного поведения героев с точки зрения современного человека: отказ спасать утопающего или обреченного на гибель в тундре, нежелание 
общаться с людьми, уже определенными в число погибших, является боязнь рассердить духов места, выбравших себе жертву. Утонувшие и обреченные на гибель превращали место гибели в священное, принеся себя в жертву.

Число семь у ненцев считалось священным, о чем не раз упоминают литераторы. На месте жертвоприношений обычно деревянные идолы были разделены в семь отдельных групп, стоящих вытянутыми рядами на расстоянии нескольких шагов одна от другой. Несколько идолов стояли отдельно по одному или два.

«Деревянные идолы со стесанной головой и грубыми насечками вместо глаз, носа и рта или в виде длинных обтесанных палок, покрытых группами зарубок по семи в каждой группе. Но кроме этих обыкновенных изображений тут находились также две или три фигуры человека, гораздо тщательнее вырезанные из дерева, и несколько изображений птиц (гагар)»- уточнял Б. Житков ${ }^{6}$.

Жертвоприношение предваряло какие-либо просьбы о помощи, и если просьбы были не столь жизненно важными и определяющими, то жертву мог приносить любой человек, в случае же судьбоносных, а также касающихся лечения прошений совершать жертвоприношение мог только тадибей. Шаман умерщвлял оленя перед идолами. Голову, рога и кожу развешивал на дерево перед ними, обмазывал кровью оленя их лица, кусок жира бросал в огонь.

Мир большинства героев произведений ненецких литераторов пронизан магией. Здесь можно выделить отмеченные этнологом Малиновским ${ }^{7}$ в донаучном сознании две «точки» соприкосновения магического и рационального миров, которые ученый называл кризисной магией и сопровождающей магией. Кризисная - герои прибегают к магии в кризисные моменты своей жизни, когда не могут обнаружить рациональным путем выход из кризисных ситуаций, т. е. когда не могут управлять своей жизнью в этом мире, например, попав в шторм, заблудившись, тяжко заболев и т. Д. Им ничего больше не остается, как искать выход, обращаясь к духам. К сопровождающей магии герои обращаются значительно чаще, стараются обращаться к магическим обрядам перед началом каждого значимого сезонного действия - перед перекочевкой, охотой, ловлей рыбы. В поступках ненецких героев зачастую проявляется сосуществование в сознании параллельности рационального и магического. 


\section{Политеизм в литературе ненцев}

Сопутствующим шаманизму было многобожие, политеизм, где основными у ненцев являлись Нум - бог небесный, Нга бог подземного мира, Я Миня - богиня земная.

Анализируя ненецкие героические песни сюдбабц, исследователь самодийских языков Н. М. Терещенко называет Я Миню «помощницей рожениц, на которой держится жизнь на земле» ${ }^{8}$.

В шаманских песнях Я Миня предстает верной и действенной помощницей как самим шаманам, так и окружающим. Она способна принести мир и благополучие. В «Обращении к Я Мине» ${ }^{9}$ шаман просит богиню быть милосердной к людям, чтобы они не знали слез и горя, жизнь их стала бы радостной и прекрасной. Для этого нужен ягель оленям, чтобы увеличивались оленьи стада, наполнились бы белой рыбой сети у рыбаков. Шаман также просит Я Миню сохранить земную жизнь детям, сделать ее светлой и богатой. Не забывает он и духов-помощников богини, у которых он тоже просит поддержки.

Ненецкие литераторы, пытаясь приобщиться к раскрытию таинственной доброты и силы Я Мини (Ямини), создали выразительный образ женщины-богини. Предначертанными Великой Яминей считает все события, происходящие с ним и с окружающими, оленевод Майма (повесть А. Неркаги «Илир»). Удивляясь тому, как обрадовались отпущенные на волю под влиянием новой власти пастухи, Майма предполагает наличие в их рукавицах тамгу (знака), «где своей властной рукой Яминя начертала путь», избавляющий бедняков от голода и нищеты. Герой, анализируя жизненные события, не раз пытается объяснить их участием Ямини. Страдая из-за того, что его сын слаб и уродлив, оленевод считает, что это несправедливый по отношению к нему поступок Великой Ямини. При этом он отгоняет подспудные мысли о том, что, возможно, сам виноват в уродстве ребенка, поскольку жестоко избил беременную жену, когда она не нашла отбившуюся от стада важенку. Майма упорно пытается оправдать свой поступок, у него нет сострадания к людям, он продолжает жалеть лишь убежавшую олениху. Герой не хочет брать на себя ответственность за свое поведение, идет по более легкому пути - обвиняет в несчастьях и бедах богиню Земли.

Мерча, отец Маймы, в молодости тоже «плутает в своих мыслях, как в густом утреннем тумане», размышляя о том, почему Великая Яминя дает человеку три вечных подарка - Землю, 
Жизнь и Любовь, но не дает ему покоя, пугает и мучает его случайностями, а главное - не может дать ему бессмертия. Эти мысли-претензии порой рождали у героя сомнения в доброте и даже существовании Ямини. И только тогда, когда от лап разъяренного медведя его спас упавший на зверя обломок отвесной скалы, оленевод предположил, что за него вступилась сама Земля. Яминя приняла землю под свое покровительство, согласно ненецким мифам и преданиям, с благодарностью от Нума, который, взяв ее в жены, увидел, какой порядок она навела на небе, родила ему семерых детей, хозяйственных, сильных и смелых. На земле за ее заботу все стали поклоняться ей, обращаться в трудные минуты. В фольклорном наследии народа немало текстов с обращениями к Ямине, которые обычно начинаются словами: «О, Яминя, - мать наша, / О, небесная наша мать!»

Леонид Лапцуй в стихах называет Яминю то таинственной Женщиной Ямала, то дивной Женщиной-тундрой, воспевает ее как «вестницу добра» и «счастья пророчицу», к которой ненцы обращаются и в непредвиденных ситуациях, и в ожидании жизненно важных перемен. Она проявляет себя спасительницей, оказывает своевременную, действенную помощь. Яминя относится к числу божеств, к которому ненецкие герои часто обращаются напрямую, без посредников. Она наиболее близка человеку по своей природе, земная, сама Земля, воплощение духа Земли.

К божествам Нуму и Нга ненцы обычно обращались через духов-посредников, шаманов, в основном, в кризисных ситуациях, во время болезни, во время сезонных перекочевок.

В фольклоре, поэзии и прозе ненцев не раз обыгрывается ситуация похищения солнца и подвиг богатырей, освобождающих солнце из неволи во имя спасения людей. В поэме Л. Лапцуя «Тёр» главный герой посвящает свою жизнь борьбе за возвращение солнца своему народу. В основе - легенда о взаимоотношениях богов Нума и Нга.

По представлениям ненцев, Нга живет под землей, в темноте, за семью слоями вечной мерзлоты. Согласно легенде, которую Хомич в 1962 году записала со слов сказителя В. И. Ядне, жителя Салехарда, подземный владыка попросил у Нума для освещения своего подземного жилья луну и солнце. Будучи в отношениях свойства (их жены сестры), Нум уступил луну и солнце, обрек землю на темноту. С этих пор люди, животные и птицы остались под слабым светом небесных звезд. Животные и птицы стали погибать, проваливаясь в ямы, натыкаясь на преграды. 
Ненцы начали приносить жертвы на святых местах, умоляя Нума вернуть свет на срединную землю. Нум собрал на совет всех небесных и земных богов. Явмал - бог верховий рек посоветовал Нуму, чтобы тот пошел в гости к Нга и хитростью добыл светила. Нум так и сделал. Отправился в подземелье и сразу же после дружеской беседы попросил Нга отдать ему свою тень, чтобы не было скучно без собеседника, когда вернется домой. Нга, до этого не подозревавший о существовании у него тени, удивился и рассмотрев ее, отдал тень Нуму. Однако тень Нга, несмотря на его уговоры и даже побои, не хотела следовать за Нумом одна, без хозяина. Нум, видя это, сказал хозяину: «Нехорошо, что ты не можешь выполнить даже такой маленькой просьбы. Что ж, долг платежом красен». После этих слов он выхватил из углов подземного жилища луну и солнце, вынес их наверх и поместил на прежнее место. И на земле снова стало светло.

Многие герои литературных произведений ненецких поэтов и прозаиков убеждены в том, что Нга представляет злое начало. Его старались умилостивить, чтобы избавиться от несчастий. Представителем злого начала является не только Нга, но и целый сонм духов, его помощников. От Нга защищали идолы-покровители человека, они спасали его и от болезней, которые якобы тот насылал. Так, мать Маймы (повесть «Илир») обращалась к его духу-покровителю, когда мальчик заболел. Для защиты от болезни женщина повесила идолу на пояс крошечный детский зуб.

Согласно мировоззрению ненцев, Нум царствует в воздухе. Его часто смешивали с видимым небом, а звезды почитали частями Нума и называли нумги, т. е. Нуму принадлежащие. Солнце тоже чествовалось как Нум или Илебеамбаерты. Из записей А. Кастрена: «На рассвете самоед выходит из своего чума и, обращаясь к солнцу, молится словами: "Когда ты, Илебеамбаерты, поднимаешься, то и я поднимаюсь”. То же делает он при захождении его, говоря: “Когда ты, Илебеамбаерты, заходишь, так и я иду отдыхать”. От иных самоедов я слышал, что и земля, и море, и вся природа - тоже Нум» ${ }^{10}$.

В героических песнях сюдбабц Нум предстает верховным божеством, которое живет на седьмом небе в золотом чуме, блеск его сияет звездами через отверстия в своде. Илебеамбаерты же является богом изобилия, именуемым иногда «корнем жизни» и помощником Нума. Как пишет Н. М. Терещенко, это доброе верховное божество, дарующее людям оленей и приносящее удачу на охоте. 
Герои ненецких литературных произведений обращаются за поддержкой и к Ямалу - одному из главных божеств наземного мира, которое борется со злыми силами (великанами, людоедами, Нга, Парнэ). Ямал (Явмал) обладает большой физической и моральной силой, иногда принимает облик священной птицы Минлей.

Парнэ - мифологическое существо, ведьма-людоедка, которая заманивает мужчин, женит их на себе, завязывает дружеские отношения с женщинами и детьми, а потом жестоко расправляется с ними. Существует поверье, что когда, стремясь избавиться от Парнэ, ненцы сжигают ее на костре, то пепел превращается в комаров и оводов, которые тоже пьют кровь человека и животных, являются для них настоящим бичом.

Злым сверхъестественным существом, вызывающим болезни, является Нылека, чье имя было нежелательно даже произносить.

Бесчисленное количество духов существовало под названием тадебцё, которые являлись посредниками между шаманами и Нумом, по сведениям других - представляли злое начало, противодействующее началу добра, т. е. Нуму. Вероятно, тадебцё были разными по своим нравственным установкам. Некоторые авторы подчеркивали, что они были невидимы ни для кого, кроме шаманов, и могли приносить как добро, так и зло.

Порой воля ненецких героев растворяется в противоречивых требованиях божеств, растворенных в мире. Предположительно, именно там, где их сознание сомневается, не уверено в разумном основании для поступка, начинаются ростки для индивидуального сознания и индивидуальной ответственности за содеянное и возникает нравственность, основанная на индивидуальном сознании, а не на коллективном бессознательном.

Поскольку длительное время в сознании ненцев превалировало, по Леви-Брюлю, participation mystique (мистическое соучастие), то и герои, особенно те, что живут волею авторов в отдаленные от современности времена, и те, кого не коснулось влияние иной культуры, продолжают жить в окружении опасности и непредсказуемости, в нераздельности себя и мира. Шаманизм был вехой на пути развивающегося сознания. Ненецкая литература стала проводником на таинственной дороге, устремленной вспять, к пониманию сущности пралогического, мистического мышления. 


\section{Семиотика камлания}

Камлание как сакральное, завораживающее действие шаманов привлекало ненецких прозаиков и поэтов, нашло наиболее яркое отражение в пьесе Ивана Ного «Шаман», в романе В. Ледкова «Месяц Малой Темноты», в повести Л. Ненянг «Судьба» и других произведениях.

Камлание шаманов - ритуал, инсценирующий внутренние события, которые происходят в трансцендентном состоянии. Шаман осуществляет связь с иным измерением, с космическим универсумом. Этот сакральный ритуал рассматривается как способ общения с духами, что достигается двумя путями: или духи вселяются в тело шамана (либо в его бубен), или, напротив, душа шамана отправляется в царство духов. Шаман обладает способностью входить в общение с духами, населяющими земной, подземный и небесный миры и тем самым берет на себя право выступать посредником между людьми и этими духами.

Путь на небеса или в подземный мир «вне тела» - духовный экстаз, переступание онтологической грани. Снимается различие между странствием в «теле» и «вне тела», между космологической и онтологической оппозициями. Одно приравнено к другому. Сознание шамана как бы функционирует одновременно на нескольких уровнях, постигает тайны, недоступные обычному человеку. Своеобразие мировидения шамана предположительно можно объяснить, например, версией известного американского ученого С. Грофа о самостоятельном функционировании сознания вне тела, во время которого человек переживает ощущение духовного полета. Шаман владеет техникой визуализации, основанной на особенностях бессознательной части психики.

Картина камлания Нгэбт Ямба (Длинноволосого) в романе В. Ледкова «Месяц Малой Темноты» высокохудожественна и вместе с тем этнографически точна. Выразительно предъявлено интеллектуальное и эмоциональное переживание шамана. Постепенно настраиваясь, он переходит из обычного состояния сознания в шаманское, в «необычную реальность». Эта способность шамана перемещаться между различными состояниями сознания и есть его удивительное специфическое свойство.

В шаманском состоянии сознания Длинноволосый становится видящим скрытый мир, предпринимает путешествие по Большеземельской тундре, о чем рассказывает в своей песне. «Быстрым горностаем» промчался он от Урала до Тиманского хребта, уви- 
дел и рассказал обо всем необычном для жизни тундровых людей - о деревянных чумах, об убивающих друг друга людях. Создавая мыслеформы и мыслеобразы, герой описывает ландшафт и бытование людей.

В процессе камлания шаман уходил от осознания реальной действительности дальше и дальше, глубже впадал в транс: «Шаман почти кричал и с силой бил колотушкой по бубну. Визжала медь, кашлял бубен, и чум снова будто зашатался, вновь полилось пугающее пение Длинноволосого». Выразительность, экспрессивность камлания усиливались по мере воздействия шамана на мысли и воображение присутствующих. С целью получения предельной эмоциональной реакции использовался целый комплекс шаманских средств. Невольное приобщение к тайнам нижнего и верхнего миров внушало присутствующим трепет, убеждало в реальности происходящего с шаманом. Обрядовая последовательность событий включала как естественные физические действия, так и символические мифические процессы из мира магического.

Художественно-образное мышление шаманизма отличается высоким уровнем визуализации. Оно исходит из принципиального разделения всех происходящих в мире событий на естественные и сверхъестественные, в отличие от мифологии, где даже самые фантастические события считаются естественными, как и обычные природные процессы. Шаманизм впитал эмпирические знания, в которых нашел отражение человеческий опыт овладения предметом и процессом природы, поскольку было накоплено достаточно сведений о мире, о том, что может произойти, а что не может. Шаманизмом не отвергаются картины реальности, построенные опытным путем. Чувственно воспринимаемый мир в нем не является единственным. Над ним существует еще мир сверхъестественный, сложным образом воздействующий на человека и управляющий им. Шаманский транс - это мир экстаза, мир сверхъестественных сил и действий. Шаман существует как бы в двух мирах: вне транса он живет обычной жизнью соплеменников, в трансе - он часть сверхъестественного мира, разделяет с духами некоторые их возможности (может летать, стать одним существом со своим духом-помощником и др.).

Шаманский бубен переносит шамана в иной мир, являясь своеобычным транспортным средством. Звуки бубна погружают камлающего в транс, переводя стрелки внутренних часов на душевное передвижение. В мифологии бубен связывают порой с центром мира и Мировым Древом. 
Согласно научным исследованиям, особый ритм бубна совпадает с рядом частот мозговых волн, связанных со сновидениями, гипнотическими образами и трансом. Звуки бубна вызывают изменения центральной нервной системы. Ритмическая стимуляция, как известно из исследований нейропсихологов, воздействует на электрическую активность многих сенсорных и моторных областей мозга, обычно не задеваемых, благодаря чему стимулируются связи с сенсорной областью. Звук барабана из оленьей кожи имеет низкие частоты, способные передавать энергию мозгу, вводить в состояние транса. Для опытного шамана достаточно только нескольких минут знакомого треска или звука бубна, чтобы впасть в легкий транс, в котором осуществляется большая часть камлания.

Встряхивание трещотки шамана обеспечивает стимуляцию в мозгу дорожек более высокой частоты, чем звук бубна, усиливая его и повышая полный звуковой эффект. Кроме того, с помощью погремушек (колькольчиков, подвесок, трещотки и др.) как бы восстанавливается вибрационная энергия рода и тотема. Колокольчики, шумящие подвески, создают «акустический код» шаманской культуры. Шаман создает темп пляской. Ритм колокольчиков и железной мелочи на его одежде ведет бубен и также снабжает его звуковыми сигналами более высокой частоты. Эта техника обеспечивает подвод в нервную систему шамана движений тела, соответствующих звукам. Танец также способствует впадению в состояние транса и ощущению «выхода» за пределы собственного тела.

Магическиая религиозная музыка вместе с танцем помогает шаману входить в экстаз, в измененное состояние сознания, поддерживать его в этом состоянии, фиксировать видения. Видение шамана считается не просто галлюцинацией. «Это визуализация умственной формации, которая тоже может некоторое время существовать независимо от своего творца. Пока человек испытывает это видение, он не может двигаться, но осознает все происходящее вокруг него» ${ }^{11}$.

Звуки бубна, колокольчиков, медных подвесок должны сопровождать мистические видения. Если звон обрывается, шаман может быстро вернуться в обычное состояние сознания, не получив ответа на поставленный им вопрос.

Превращению в шаманское состояние сознания помогает также пение песни-силы, которую он исполняет в этих случаях. Шаманская песня выражает силу и намерения. Эта песня обладает особой магической энергией. 
Антрополог Джон Галифакс писал:

«Точно так же, как Мировое Дерево произрастает в центре обширных космических пространств, песня пребывает в самом средоточии космоса индивида. В тот момент, когда из уст шамана вырывается песня, когда из глубины его сердца поднимается священное дыхание, он обретает внутренний центр и подключается к источнику всех божественных сил» ${ }^{12}$.

Характерная особенность камланий - повторение присутствующими некоторых действий шамана, выкрикивание вслед за ним заклинаний. Эхопраксия и подражательный автоматизм поведения отмечены И. Ного в пьесе «Шаман», Л. Ненянг в повести «Судьба».

Изменение сознания - это не только использование различных музыкальных инструментов и песнопений, но и специальных техник дыхания, а также психотропных средств. Среди психоделических растений, использовавшихся шаманом, был красный мухомор. Видения и галлюцинации вызывают шаманы и с помощью других священных грибов и растений. Галлюциногенные, психоделические растения оказывают на организм биодинамическое воздействие, но не вызывают у шаманов привыкания, поскольку используются обычно только во время камланий. В процессе камлания шаман может войти в обычное состояние сознания и, общаясь с окружающими, уточнить, где он был, что делал. После перерыва он возвращается в шаманское состояние сознания, чтобы продолжить свое общение с духами или с предками и найти средство для лечения болезни или узнать будущее.

В пьесе Ивана Ного «Шаман» Пева во время камлания несколько раз «возвращается» и сообщает об увиденном. Во время одного из таких «возвращений» он говорит: «На земле и на небе никого я не пропустил. Хозяев земли, водяных хозяев - всех обошел. Одного только какого-то духа одолеть не могу. Если одолею его, то сразу скажу вам, тогда исцелитесь».

Шаман Тарнгэ в повести Л. Ненянг «Судьба» также несколько раз «возвращается» и сообщает о том, что к нему пришли деды и прадеды, предки, чтобы помочь, но духи упорствуют и не хотят вернуть душу больной. Чтобы справиться с ними, нужны жертвоприношения. Их и приносят заинтересованные в выздоровлении родственники: то важенку, то олененка, а в конце песцовую шкурку.

Шаманское камлание и в пьесе Ного, и в повести Ненянг разворачивается по универсальному мифологическому «сценарию»: 
от бесформенного к оформленному, от разрушения к созиданию, от Хаоса к Космосу. Хаос - это отступление от нормы. Злые духи похищают душу, душа - воздух. Возвращение ее приводит к выздоровлению.

В описаниях камлания начало обряда обычно носит сумбурный характер: невнятное бормотание, похожее на звукоподражание стихиям природы, а также птицам, зверям; жесты шамана нечетки, поведение непредсказуемо. Помощники шамана иногда даже держат его, так как он начинает буйствовать. Нгэбт Ямбы в романе «Месяц Малой Темноты» начинает камлание согласно национальным представлениям о нем. Автор выразительно, мастерски описывает действие, создавая напряжение и пробуждая тревогу: «Длинноволосый затрясся, как в ознобе, с него посыпался звон бубенчиков. Шаман сел прямо, на миг застыл - и вот пошла гулять по бубну колотушка из моржового клыка! Застонал бубен, зазвенели медные кольца с цепочками, запело все одеяние шамана, усиленное пластинками из металла. Тягучее “э-э-э!” перешло не то в плач, не то в горькую протяжную песню».

Наполнена экспрессией и отражает знание автором тонкостей шаманских действий картина начала камлания шамана Тарнгэ в повести Л. Ненянг «Судьба»: «Шаман разогрел у костра бубен, убедившись, что он упруг, стал колотить. Сначала его движения были медленны, слова-заклинания выговаривал он тихо, спокойно. Но вот он будто ожил, все быстрее и быстрее стал подпрыгивать, громче петь, даже выкрикивать, созывая к себе духов. Лоскутки разноцветных сукон, черных и белых оленьих шкур, пришитые к его одежде, напоминали при камлании перья птиц, и тогда шаман походил на ястреба, кружащегося над своей добычей. Потом он падал. Долго лежал так».

Шаманы во время своих сакральных действий чаще всего обращались к Нуму, к духам и к своим предкам. В «Призывании духов» (песня шамана Окотэтто, запись в сборнике составителя Л. А. Лара) перед присутствующими во время камлания людьми, которые пришли «посоветоваться о жизни», шаман образно и выразительно представляет свой путь к Нуму на седьмое небо за советами и помощью. В поддержку себе он призвал Семирогого оленя, обуздать которого помогают духи, а также священную птицу Минлей, способную вызывать и останавливать грозы, бороться со злыми духами. Из песни шамана присутствующие узнали, что по пути к Нуму, состоявшему из семи небесных дорог, он «одолел злого духа, пожирающего разум, - Хансосяда, унич- 
тожил великана-людоеда Сюдбя». Странствия шамана в иной мир, испытания напоминают порой приключения персонажей народных сказок и героических песен сюдбабц.

Семиотика шаманских действий в камланиях очень насыщена. Схождение ритуальных действий и предметов шаманского быта раскрывается через символическую природу языка культуры. Ритуальные предметы шамана имеют особую семиотику. Так, на колотушке и самом бубне были символические рисунки, а при изготовлении соблюдались определенные правила: ветки с дерева срезал старый человек с восточной стороны дерева, так как запад связывался с обиталищем злых духов. В чуме шамана на вершине священного шеста, который олицетворял не только дух очага, но и ось мира, находилось деревянное изображение волшебной птицы минлей. В ненецких мифах семикрылая птица минлей то помогает внуку старухи из подземного мира, осуществляя связь трех миров - подземного, земного, небесного, то похищает земных жителей.

Ненецкие авторы не раз в своих произведениях описывали одеяния героев-шаманов. Одежде шамана придавалось особое значение. Шапки шили из шкур определенных зверей: выдры, соболя, горностая и украшали бисером и бусами. На лбу и по бокам шапки прикреплялись изображения лиц, вышитых бисером на овальных кусочках ткани. У них обозначены овал лица, глаза и нос, а рот отсутствовал, чтобы дух-помощник шамана не мог раскрыть посторонним свои тайны. Для уподобления зверям и птицам шаманы одевались в шкуры и надевали маски животного, птицы, например, орла, медведя, оленя, которые являлись для них источником силы. Шаманы умело подражали их поведению. Так, слепой Пева из пьесы «Шаман» подражает крику гусей, уток и лебедей, вою волка. Считалось, что это один из способов привлечения духов. Выполняя это действие, шаман ощущал сильный прилив энергии, глубокое чувство преображения. Он как бы становился другой сущностью, наполнялся ее энергией.

Приступая к камланию и во время его, шаманы периодически обращались к окружающему пространству. Слепой шаман Пева (пьеса «Шаман»), взяв наощупь разогретый бубен, направляет его в разные стороны, изредка постукивая по нему, опуская его к огню после обращения к каждой стороне света. Только после завершения своеобразного контакта с четырьмя направлениями шаман садится на шкуру и продолжает свои сакральные действия. 
Камлание - это мистическая драма с танцами и песнями. Во время ритуала шаман, судя по его словам, переживает тревожные события, вступает в борьбу и может даже погибнуть. Или, наоборот, набраться волшебной силы, как Тэбка Тоги в поэме «Огненный суд» Л. Ненянг. После камлания, во время которого герой одержал победу, он «упал, и зашипела пена возле синих губ», но через некоторое время поднялся и продемонстрировал свою обретенную воинскую силу молодого воина:

Колотушкой грохнул в бубен -
снег посыпался с березок.
Сила вновь вернулась к Тэбку,
стал он снова молодым!
Он вокруг костра запрыгал.
Взгляд горит и голос грозен.
Он летал, не обжигаясь,
над огнем сквозь черный дым.

По выполняемым в социальной жизни ненцев функциям шаманы разделены этнологом Л. В. Хомич на три категории: 1) выдутана - творящий чудеса, относящийся к небу, связанный с небом, 2) янянгы - к земле относящийся шаман, 3) самбана шаман, общающийся с подземным миром ${ }^{13}$.

На основе изучения характера деятельности известных шаманов и терминов в тундровом диалекте Е. Т. Пушкарева в своем диссертационном исследовании выделяет четвертую категорию «юдерта» - шаман-предсказатель, видящий вещие сны, толкователь снов. Она утверждает, что шаманы разных категорий часто подменяли друг друга и выполняли разные функции. Такую подмену нередко отмечают авторы литературных ненецких произведений, создавая образы шаманов.

Факторы смешения функций у одного шамана пришли в литературу из ненецкого фольклора. В волшебной сказке об Уриеpe, записанной Александром Кастреном, сказано: «Жил в старину на земле тадибей, по прозванию Уриер, и был он тадибей над тадибеями, мудрец над мудрецами, врач над врачами, вещун над вещунами, такой знахарь, каких теперь уже не бывает. Нужно ль отыскать пропавшего оленя, добыть украденное, возвратить здоровье, уготовить себе счастье и богатство и другое такое, и не ходи за советом ни к какому другому тадибею - ступай прямо к Уриеру». После того, как земная жизнь тадибею наскучила, он отправился вместе с двумя женами на оленьей упряжке по воздуху на небо. «И там нашел все, что хотел». 
Ненецкая литература убеждает нас как в наличии всех четыpex разновидностей шаманов, так и в том, что большинство из них способны выполнять разные функции: и предсказывать, и лечить, и отводить беды, и творить чудеса. В пьесе «Шаман», написанной Иваном Ного на ненецком языке, изданной в Салехарде в 1937 году в переводе на русский язык фольклористом Г. Д. Вербовым, главный герой - слепой шаман Пева совмещает две способности - он и выдутана, врачеватель, и юдерта, прорицатель. Его действия в этих ролях этнографически точны. Во время камлания с целью определения причины болезни вогула (манси) и его жены Пева, долго общаясь с духами, якобы узнал от них, что вогул болеет потому, что его предки не принесли когда-то в жертву обещанного оленя, и кроме того, непочтительно относились к изображениям духов. Исполнив обещанное предкам, он может поправиться через два-три дня. Жена же вогула болеет из-за того, что «по запретным местам хаживала, на разные вещи ногами наступала. А разве можно так делать женщине?!» Виновата она и в нарушении супружеской верности: «Когда ты уже мужней женой была, с другими мужчинами сходилась. За это духи тебя наказали». Только обещание недопускать в будущем измен мужу может, по мнению духов, принести ей избавление от болезни.

Необычным для шаманских действий у ненцев является появление христианского святого. Во время второго камлания, представленного в пьесе «Шаман», Пева как юдерта приглашает двух духов - Ямала и Николу. Дух Николы (Николая Чудотворца) вошел в пантеон ненецких духов под влиянием другой религии - христианства, появившегося у ненцев в начале XIX века. Миссионеры крестили ненцев, но укрепить их в новой вере не смогли, оставив лишь слабые следы религиозного синкретизма. Святому Николаю Чудотворцу была посвящена, например, церковь в Обдорске, в которой находились икона с его образом и скульптурное изображение, его уста ненцы мазали кровью пожертвованных животных.

В пьесе И. Ного шаман, обратившись к Ямалу и Николе, предупредил присутствующих, что приход духа Ямала будет обозначен одним ударом по ящику, а приход Николы, жизнедателя и хранителя стад - оленьим хорканием, стуком копыт оленей во время кормежки. У пришедших невидимых духов присутствующие сами могут просить для себя оленей. Шаман же при поддержке бубна будет рассказывать присутствующим о предсказа- 
ниях духов. Он предупредил, что, возможно, после ухода духов удачу или трудности в предстоящем году передаст оленеводам голосами зверей и птиц. Так, волк о благополучном годе известит одноразовым криком. «Если плохой год для оленей - по-собачьи завоет. Потом птицы прилетят: гуси, утки, лебеди. Разные другие звери придут. Все с криком, с голосом». Шаман Пева предупредил, что его поведение будет знаковым, требующим особого внимания присутствующих, выполнения ими ритуальных действий. Он рассказал, как присутствующие могут расшифровать предсказание на будущий год: если в конце камлания духи вознесут его наверх, то вернуть могут разными способами: если обратно на землю усадят - к добру, а если бросят на пол чума - к невзгодам. Огонь в очаге при этом должен быть погашен. Присутствующие во время камлания беспрекословно и с тайными надеждами на добрые предсказания выполнили указания Певы. Когда же после завершения камлания зажгли огонь, то все увидели шамана залезшим до половины высоты вертикального шеста, и это символизировало ожидание совершенно необычных ситуаций.

В пьесе Л. Ненянг «Судьба» выдутана Тарнгэ в течение длительного сеанса пытается излечить главную героиню Нелё от душевной болезни, в которую та впала из-за жизненных невзгод. Шаман просит духов своих предков помочь вернуть душу женщины. Лишь после жертвоприношений ему удается, приложив ухо к земле, услышать ответ: «К Нелё ум придет. Скоро придет. Я же говорю, мои предки все могут». И действительно, следующей весной однажды женщина проснулась «с хорошей душой». Удивленная Нелё пребывала в недоумении, почему же, когда стал ее ум ясным, ее душа стала холодна. Все как бы стерлось в ней. «Как чум без хозяина стала». Можно лишь предположить, что ее душа и она сама, освободившись от прежних эмоций, с нуля начали новый виток жизни после пребывания в хаосе.

В ритуалах исцеления отчетливо прослеживается мысль о том, что жизнь нельзя исправить, а можно только создать заново посредством воспроизведения космогонии. Осуществляется артикуляция космогонического мифа о вечном возрождении.

Если сравнить экстатическое состояние шамана перед камланием или во время его и творческое вдохновение поэта, можно заметить определенную внутреннюю связь между этими двумя сложными и неразгаданными процессами. Как уже отмечалось, шаманы настраиваются с помощью ритмических то гремящих, 
то трепещущих звуков или других приемов, чтобы отключиться от реальности и войти в транс.

В возбужденное состояние, стимулирующее вербализацию и создание поэтических строк, зачастую погружаются и поэты, а раньше - сказители, творцы фольклора и эпоса. Шаман переносит присутствующих в инфернальный мир с чудесами, в котором возможно все, где прославляется высшая «свобода», где отменяются «законы природы». Не к тому ли стремится и поэт, писатель, создавая свое произведение, а еще раньше устремлялся безымянный творец устных народных произведений? Внимательное медленное чтение фольклорных и литературных ненецких произведений и сравнение с описаниями действий шамана во время камлания в этнологической, исторической, художественной литературах убеждают в сходстве приключений персонажей народных сказок и героев эпической, художественной авторской литературы со странствиями шамана в иной мир, испытаниями, переносимыми им во время экстатических инфернальных нисхождений и небесных восхождений. Нередко сказители заимствовали шаманские сюжеты. Камлание как театрализованное действо оказывало на присутствующих сильное эмоциональное воздействие, способствовало творческому вдохновению сказителей, поэтов, которые трансформировали «путешествия» шаманов в сказках, песнях, стихах.

\section{Отражение ритуалов посвящения в шаманы в литературных произведениях}

Шаман - слово из языка тунгусов, примерный смысл его «обладатель магической силы», поэтому главными условиями для человека, готовящегося стать им - развитие умения входить в трансцендентальное состояние сознания, обретение личной силы, знаний и духов-помощников. Воздействовать магически на реальность могут лишь обладатели названного «инструментария».

Посвящение в шаманы, инициация, - сложный феномен, включающий подготовку и проведение сакральных обрядов, среди которых ритуальная смерть и воскрешение, испытание на выносливость, развитие интуиции, способности проявить фантастическое воображение, которое может отделить от непосредственной реальности, чтобы понять, «что есть образ жизни, недоступный непосредственному опыту, и что этого образа жизни можно достичь, только отвергнув грубую веру в неуязвимость 
материи» ${ }^{14}$. Посвящению в шаманы обычно предшествовало накопление умений пробиваться в магическую реальность, добиваться ощущения пребывания вне собственного тела, телепатических и духовных впечатлений и ярких видений.

Выстраданный путь овладения шаманским мастерством стал завуалированной сюжетообразующей нитью, организующей поведение главного героя в поэме-сказке «Тёр» Леонида Лапцуя. Просматривается в процессе анализа текста шаманская природа, заложенная в основу произведения, скрытая от атеистически настроенного читателя (повесть написана в конце семидесятых годов XX века). В поэме представлена своеобразная реконструкция идей шаманства, раскрывающая синтагматические связи между отдельными фрагментами шаманского действа, сложности постижения мастерства.

Для утверждения иключительных многогранных способностей, значимости героя автор проводит его через целую серию подготовительных сеансов-ситуаций, подобных тем, которые необходимы для развития экстраординарных способностей шамана.

С ранних лет Тёр находился в условиях изоляции, он был полностью лишен общения со сверстниками, так как прятался от врагов, жил со своей тетей несколько лет в волчьей норе. Эта женщина, сестра отца, спасла и спрятала младенца, ставшего единственным продолжателем рода, поскольку всех остальных уничтожили в неравном бою кровожадные и коварные Ваи, продолжавшие поиск будущего мстителя и много лет спустя после своей неправедной победы.

У Тёра формируется интравертный характер, отличающийся склонностью к задумчивости и уединению, сосредоточенностью и наблюдательностью. Такими же интравертами, склонными к самоизоляции с самого детства, обычно были и будущие шаманы. В волчьем логове хозяева-волки жили вместе с мальчиком и женщиной довольно мирно, не нападали, хотя порой «щерили зубы, щетинили спины», не хотели делиться добычей, и тогда спасительница женским ножом отбивала у зверей куски оленины. Общество волков, а потом, когда женщина поставила чум, одиночество, сопутствовали детству героя. Занятая постоянным изнурительным трудом, чтобы прокормить и обогреть себя и мальчика, женщина искала поддержку у волшебного старинного бубна, который взяла с собой, убегая от врагов. Она постоянно беседовала с «сокровищем предков», выслушивая мудрые мысли. 
Обычным явлением для посвящения в шаманы являлась передача «профессии» по наследству. Тёру свои умения передала его тётя, основная цель жизни которой - вырастить мальчика, героя, способного отомстить врагам за содеянное зло и спасти род. Женщина владеет паранормальными способностями, может благодаря чудодейственному бубну услышать зов помощи и оказать ее. Она помогает наследнику в самых сложных ситуациях, даже находясь от Тёра в отдаленном пространстве.

Перед тем, как юноша отправляется в путь, защитница рода Тёров дает ему ценные наставления и волшебных помощников: семиузорные кисы, «сносу которым не будет в пути»; трех медведей, что примчатся «с моря как ветер», если взмахнет он правой рукой; две ивы, «сородичи предков», которые могут превратиться в лыжи и даже обеспечить одеждой; самшитовый бубен, чья ворожба в тундре всесильна.

Перечисленные волшебные помощники героя были способны преодолевать огромные расстояния и материализовываться в опасные моменты по его зову. Интересно, что их магическая сила терялась, как только они и герой оказывались за пределами тундры. Так, Тёр остался без духов-помощников, когда приехал в город, место, удаленное от тундры, где они сразу потеряли свои волшебные свойства, оказались беспомощными. Необычное пространство лишало героя трансперсональных возможностей, способности осуществлять связь с бабушкой-шаманкой. Лапцуй называет тетю героя по-разному: старушка, старшая сестра отца. Автор опирается на традицию ненецких мифов, сказок, эпоса не присваивать имена героям, кроме главных. Вместо имен употреблялось название по родству по отношению к главным героям.

Обучение и посвящение героя в шаманы растягивается, как и в реальности, на долгие годы и сопровождается суровыми физическими и психическими испытаниями. Это подобно тем, которые переносили юноши, чтобы стать взрослыми, только гораздо более суровые.

Среди испытаний - длительная боль и «семикратный опыт одиночества», по выражению Фридриха Ницше. Все это призвано отсеивать немощь, малодушие и несерьезные намерения.

При подготовке и во время инициации герой доходит до запредельного в глазах обычных людей уровня сложности.

Герой Тёр проходит путь страданий, который является одновременно и путем познания. Путь шамана - это путь преодоле- 
ния препятствий, постоянного ограничения, доказательства истины. Герой как бы сознательно обрекает себя на мученичество испытания, проходит через все категории заблуждения. Без раскрытия символики инициации - приобщения героя к шаманским таинствам оставалось бы непонятым постоянное возвращение Тёра к своим врагам Ваям, стремящимся уничтожить его. Во время первой встречи жестокий Вай бьет беззащитного юношу свинцовой колотушкой, во второй и в третий раз - свинцовой колотушкой, смазанной ядом. «Трижды он юным лицом холодел», переживал смертельное состояние. Такое заглядывание смерти в лицо, сознательное путешествие навстречу ей является одним из парадоксов шаманизма, поскольку «самоисцеление означает познание, трансформацию сознания» ${ }^{15}$.

Троекратная смерть и возрождение позволили герою без поддержки помощников выплыть и забраться на льдину, прыгнуть «вдаль на сто саженей вслед за кораблем», самому справиться с ранами на руках, нанесенными «острым тесаком», понять голос ветра, предупреждающего об опасности: льдина, на которой он плывет, подтаивает. У героя еще недостаточно шаманских сил, он может лишь телепатически связаться со старушкой, пославшей ему в поддержку советы говорящего бубна, поэтому голосов проплывавших мимо тюленей он не может расшифровать и осознать самостоятельно: они приплыли ему на помощь. Старухе приходится для спасения Тёра посылать плывущую огромную корягу. Коряга - символ человеческого древа, поддержка предков.

В поэме герой проходит полный цикл овладения шаманским мастерством. Один из существенных моментов, который можно уже отнести к акту инициации - соревнование с равным и даже превосходящим по силе противником-великаном. На пределе возможностей идет борьба, в которой богатырь Тёр побеждает и получает в помощники духа-супругу. Трехкосая владеет способностью творить чудеса с помощью своих кос, обладает мудростью и силой шаманства. Из первой косы сплела она плетенку, на которой с помощью ветра взлетели Тёр и Трехкосая через три слоя облаков «в просторы синевы, где не смеют тучи кочевать, радугу и солнце закрывать». О том, что Тёр постепенно обрел способности транспсихической коммуникации и магические возможности передвигаться на нартах невидимкой, свидетельствует сцена его борьбы в конце поэмы с врагами своего кумира, человека, похожего на отца, его победа над превосходящим по численности противником. Кумиром для Тёра стал Воитель 
Старший и потому, что «за миг до смерти страшной» был вынесен им с поля битвы. Автор подчеркивает особые способности Тёра, решившегося на сложную битву вместе с другом: герой «как будто силой колдовской ведет войны ремесла». Став невидимым, благодаря своим волшебным нартам, он занимается разведкой. Помогает и то, что он подружился со всеми жителями лесного мира - «до самой малой пташки», ведет разговор с деревьями и зверями. Именно они предупреждают его о коварстве врага, который поджег тайгу. Тёр выкопал ров и стал убеждать дух огня не превращаться из доброго духа в злого. Он красочно представил, какие несчастья влечет за собой пожар в тайге. Огонь вступил с героем в диалог и высказал все обиды, среди которых главная: зависимость его от чужой воли: «Добрый хозяин по-доброму держит меня. Злой помыкает безропотной силой огня». Сила шаманского воздействия Тёра оказалась недостаточной для прекращения огня. Только трансперсональная связь с Трехкосой помогла справиться с пожаром: выпал «внезапный снегопад над летнею землей».

Фантастические способности шаманов оказывать влияние на природные явления были известны среди ненцев, о чем свидетельствуют легенды, записи этнографов. Символические действия приводили к реальным результатам, ритуал оказывал практическое воздействие не только на людей, но и на силы природы таков был итог шаманских представлений и сеансов. Осуществлялась тесная связь между символическим микро- и физическим макрокосмосом.

Постижение особенностей восприятия верования не только поэтами, прозаиками, но и их современниками, с помощью различных приемов анализа и интерпретации художественных произведений может оказать поддержку исследователям других научных направлений, занимающимся реконструированием модели шаманизма у ненцев. Литературоведение все больше внедряется в систему научных знаний более широкого масштаба - не только гуманитарного направления, но и естественнонаучного. По мнению некоторых ученых, в частности академика-физика В. Легасова, наступает эра гуманитарных наук, способных делать методологические «подсказки» естественнонаучным типам знаний. Отчасти это происходит и сейчас. В Международном центре ядерных исследований в Швейцарии обсуждается идея создания Института высоких гуманитарных технологий, которая зиждется на предположении о том, что на физические и технические формы исследо- 
ваний и производства могут влиять гуманитарные знания, изыскания в области эстетики, искусства, литературоведения.

1 Элиаде М. История веры и религиозных учений: от Магомета до Реформации / Пер. с фр. М.: Академический проект, 2015. С. 16.

2 Липперт Ю. История культуры в отдельных очерках. СПб., 1902. C. 445 .

${ }^{3}$ Банников К. Л. Мир шаманских образов // Архетипипические образы в мировой культуре. Всероссийская науч. конф. Тезисы докладов. СПб: Издво «Государственный Эрмитаж», 1998. С. 49.

${ }^{4}$ Новик Е. С. Обряд и фольклор в сибирском шаманизме. М., 1984.

${ }^{5}$ Старцев Г. А. Самоеды (неница): Историко-этнографическое исследование. М.;Л., 1930. С. 114-115; Евсюгин А. Д. Ненцы Архангельских тундр. Архангельск, 1979. С. 24.

${ }^{6}$ Житков Б. М. Полуостров Ямал. СПб., 1913. С. 49-50.

${ }^{7}$ Малиновский Бронислав. Магия. Наука. Религия: Пер. с англ. = Magic, Science, and Religion / Вступ. статьи Р. Редфилда и др. - М.: Рефл-бук, 1998. - 288 с. — (Созвездия мудрости (Astrum Sapientiae)). — ISBN 5-87983065-9.

${ }^{8}$ Терещенко Н. М. Ненецкий эпос. Материалы и исследования по самодийским языкам. Л.: Наука, 1990. С. 34.

9 «Обращении к Я Мине» - шаманская песня, записанная в исполнении Тэсидо Эльвиры и напечатанная в сборнике «Мифы и предания ненцев Ямала», автором-составителем которого является Л. А. Лар, ответственным редактором Е. Т. Пушкарева. (Тюмень, 2001.)

${ }^{10}$ Путешествие Александра Кастрена по Лапландии, Северной России и Сибири. М., 1860. С. 130.

11 Харнер Мишель Дж. Путь шамана, или Шаманская практика / Пер. с англ. М., 1991. С. 77.

${ }^{12}$ Halifax Joan. Samanic Voices. 1979. P. 30.

13 Хомич Л. В. Шаманы у ненцев. // В кн.: Проблемы истории общественного сознания аборигенов Сибири. Л., 1981. С. 6-8.

14 Элиаде Мирча. Азиатская алхимия. М., 1998. С. 473.

15 Хольгер Кальвайт. Шаманы, целители, знахари. Древнейшие учения, дарованные самой жизнью / Пер. с нем. М., 1998. С. 171. 


\section{Глава 6}

\section{СОЗДАТЕЛИ МИФА НОВОГО ВРЕМЕНИ}

Сознательно и бессознательно трансформируя в поэзии и прозе мифологические представления на переломе эпох и традиций, ненецкие поэты и прозаики создавали и создают поэтическую картину мировидения своего народа, вобравшую в себя представления как древних мифов, ритуалов, традиций, обычаев, так и установки иного времени. Биографии создателей письменной ненецкой литературы, их своеобычный жизненный и творческий путь, миропонимание - часть истории народа, мифа нового времени. Обращение к ним (биографиям) - один из подходов освоения мифопоэтики их произведений, представленной в них картины мира, поскольку, согласно концепции М. М. Бахтина, произведения становятся самовыражением «я» автора, его поступков, которыми писатель со-бытийствует с окружающим миром, вступает с ним в диалог. На примере жизни и творчества двух поэтов - Леонида Лапцуя и Юрия Вэллы (Айваседы) сделана попытка раскрыть своеобразие их художественного восприятия мира, ролевого «жизнетворчества», выявить возможное сходство поэтических миров двух поэтов, имевших общие мифологические истоки, преемственность фольклорных и эпических традиций, а также определить различие в творческой индивидуальности, в особой организации лирического самовыражения. Не вызывает сомнения, что индивидуальные мифы личностей обеспечивают жизнеспособность как литературного процесса, так и культуры в целом, становятся важным звеном в их развитии и обновляемости.

Символическим аналогом поэтической души двух ненецких творцов стали птицы - мифологические посредники, осуществляющие космическую связь. Устремленность птиц ввысь подобна путешествиям среди миров сакральных сказочных оленей, их 
свобода и таинственные способности породили взлет фантазии, воображения, мысли поэтов. «Я лечу на упряжке двадцатого века», - ассоциировал свою жизнь Леонид Лапцуй. С мистическим миром полетов связывал свои мечты и Юрий Вэлла (Айваседа): «Лететь, лететь хочу, как в снах далеких детства...»

\section{Поэтический миф в ХХ веке (60-80-е годы). Леонид Лапцуй}

Ненецкий поэт Леонид Лапцуй (1932-1982) - автор более двадцати книг на ненецком и русском языках. Творчество Лапцуя - своеобразный поэтический вклад в историю ненцев, поскольку тематика и содержание произведений тесно связаны с судьбой этноса, а осмысление во многом тождественно авторской интенции. В связи с этим постижение поэтической индивидуальности Леонида Лапцуя невозможно без опоры на биографический и автобиографический материал, раскрывающий социальные условия жизни ненцев, исторические события середины $\mathrm{XX}$ века, воссоздающие жизненно-творческий путь поэта. Краткая автобиография, материалы которой частично использованы в работе, была написана Л. Лапцуем за несколько дней до смерти и находится в доме-музее Л. Лапцуя в г. Салехарде.

Выделяя интенционалистский тезис в интерпретации поэтических текстов Лапцуя в число ведущих, невозможно не уделить должное внимание и аллегорической интерпретации, чтобы понять скрытый подтекстовый материал. Поэзия - плод вымысла, продукт глубинного «я», и биография, литературный портрет, позволяющие раскрыть сознательную интенцию автора, недостаточны для раскрытия символики произведений. В связи с тем, что Лапцуй был носителем мифологического сознания, тонким знатоком этнокультуры, постоянно обращался к памятникам народного творчества, важно погрузиться в его национальный мир. В кабинете музея-квартиры Лапцуя немало фольклорного материала, собранного и обработанного им (напечатанного на страницах газет, журналов, сборников) и ещё не обработанного. Поэтические мотивы, сюжеты, образы ненецкого устного народного творчества в произведениях Лапцуя получили свое развитие в описании как прошлого этноса, так и современности, эволюционировали в содержании произведений. Творчество Лапцуя пропитано этнопоэтикой - унаследованными схемами, концепт-образами.

Как уже отмечалось, проблемы мифопоэтики, национального своеобразия литератур народов Севера тесно связаны с постиже- 
нием мировидения, эстетического сознания народа, с его историей, которые нашли отражение в жизненно-творческих портретах писателей, в их произведениях. В связи с тем, что при изучении их творчества рассмотрению подлежат, в первую очередь, преимущественные тенденции национальных поэтик, то использование термина «этнопоэтика» уместно, хотя и не бесспорно по своей сути, поскольку этнопоэтика включает в себя исконные свойства поэтики.

Рассматривая проблемы поэтики, С. С. Аверинцев писал, что «вопрос о поэтике литературы - двуединый вопрос». Один аспект проблемы - история и человек; второй ее аспект — человек и слово. Литературное слово должно быть соотнесено с историей, с социальными и политическими реалиями истории, но соотнесено не иначе, как через человека, поскольку история реальна только в человеке. «Когда мы пытаемся прочертить линию, ведущую от социальных структур к жанровым структурам, линия эта не должна миновать человека, его самоощущения внутри истории, его догадки о самом главном - о его "месте во вселенной”» ${ }^{1}$. Связывая автора с литературным словом, исследователь отметил, что литературное слово порой условно и непрозрачно, поскольку может быть социально и несвободно как знак несвободы самого человека и закрытости его внутренней жизни. «Человеческое содержание может найти в литературном слове не только прямой, но и косвенный, парадоксальный выход»². Действительно, для литератур советского периода косвенный выход характерен из-за жестких установок формирования некой единой общности «советский народ», которые нивелировали и устраняли вековые традиции и обычаи. Но поэтика произведений поэтов и писателей народов Севера, несмотря на достаточно жесткие требования к произведениям социалистического реализма, проникнута использованием «условных и непрозрачных» слов, косвенно отражающих мировоззрение и мнение этносов, истинное мнение авторов о происходящем. В эпоху смены культурной парадигмы, сопровождавшейся активным проникновением в сознание иной культуры, связанной с принципиально иной системой концептуальных архетипов, духовных ориентиров, писатели и поэты народов Севера в большинстве своих произведений сумели проявить твердость духа и не отказаться от традиционного, этнического. Они брали за основу традиционный быт своих уникальных народов, стараясь вписать их в современность, нередко обращаясь к своему жизненному опыту. Они выразительно воспроизводили 
самые яркие впечатления собственной жизни, то, как они и представители их рода, этноса проходили школу жизни в меняющихся социальных и культурных условиях. Автобиографический материал стал основой для создания первых письменных художественных произведений как ненецких авторов, так и представителей других народов Севера. Лапцую хорошо были известны автобиографические повести зачинателей литератур народов Севера - юкагира Тэки Одулока, коряка Кецая Кеккетына, ненца Николая Вылки, коми-ненецкого писателя Ивана Истомина. Биографический материал, авторская интенция пронизывают и произведения Леонида Лапцуя, и его современников - чукчи Юрия Рытхэу, ханты Юрия Вэллы.

Народная культура как своеобразный памятник времени, работы человеческого духа оживает и проявляется в творчестве ненецкого поэта. Лапцуя. У него среди основных источников питания - традиционная ненецкая культура, фольклор и сама жизнь со всеми ее перипетиями, взлетами и падениями, реальный мир современности. Поэт постоянно пытался разговаривать с читателем-современником. Своим вдохновенным, наполненным духовной жизнью прошлого и помнящим о реальной жизни, творчеством он обрел право войти в историю своего народа.

\section{Жизненно-творческий путь поэта}

Леонид Васильевич Лапцуй родился 28 февраля 1932 г. в семье потомственного оленевода в стойбище у озера Ямбо-то на полуострове Ямал. Родители дали ему имя Вэсако, означавшее «мудрый старец». Если исходить из обычая ненцев присваивать имя, связывая с обстоятельствами, которые сопровождали появление малыша (после рождения малыша первым вошел в ярангу какой-либо человек, или отец увидел первого человека, животное, растение), то можно предположить, что рождение поэта было отмечено визитом одного из мудрецов стойбища. Ненецкое имя Вэсако при поступлении мальчика в школу заменили русским именем Леонид, о чем он писал: «Русская учительница, видно, / Слишком взрослым имя то сочла, / И меня, Вэсаку, Леонидом / В честь родного сына назвала». Вдохновленный идеями иной, более светлой и радостной жизни, поэт вовсе не осуждал потерю своего первого имени, а даже находил объяснение этой перемене.

Фамилия же Лапцую была присвоена по названию отцовского рода, издревле кочевавшего у озера Ямбо-то, в окрестностях ны- 
нешнего города нефтяников и газовиков Надыма. Еще в XVIII в. царские сборщики податей записывали название рода в качестве фамилии, а в 30-х годах XX века эти фамилии были узаконены в паспортах и свидетельствах о рождении ненцев.

Происхождение названия рода Леонид Лапцуй трактовал как «человек, продолжающий род», связывая со сказками, в которых сюжет разворачивается вокруг героя-мальчика, которого спасает женщина во время сражения. «Тебе надо выжить, видишь, злой враг всех твоих сородичей погубил. Тебе быть продолжателем рода, и ради тебя женщинам разжигать родовой огонь», - говорила обычно спасительница малолетнего наследника, пряча его в разгар боя в ямке, образовавшейся на снегу под железным листом, на котором разводили огонь. Улучив момент, она уносила малыша и скрывалась в каком-либо отдаленном опустевшем чуме или даже в логове зверя, растила героя-мстителя за пострадавший род. Эту версию происхождения названия рода и впоследствии фамилии Лапцуй изложила этнограф Л. В. Хомич на основании легенды ${ }^{3}$. Вэсако рано лишился отца - в 1942 году, в суровое военное время. Больная мать и маленькие братья остались на попечении десятилетнего мальчика. Вэсако ставил капканы на песца, ловил рыбу со взрослыми рыбаками. В 1943 году он поступил в Новопортовскую школу-интернат. После окончания «семилетки» он, движимый желанием помочь больной матери и страждущим ненцам, у которых в те годы была велика детская смертность, а человеческий век длился в среднем лишь сорок лет, поступил в 1959 году в Салехардское медицинское училище.

Годы в медучилище ознаменовались событием, которое оказало решающее влияние на приобщение Леонида (Вэсако) Лапцуя к литературному творчеству: коми-ненецкий писатель Иван Истомин, редактировавший в те годы местную газету на ненецком языке, предложил сотрудничать в «Красном Севере»: записывать и делать литературную обработку ненецких песен, сказок, легенд.

Работа в газете принесла как моральное удовлетворение, так и материальную поддержку, позволив более ощутимо помогать больной матери и маленьким братьям. Приходилось нелегко. «Свободного времени у меня почти не было: учился, сотрудничал в газете, занимался спортом, участвовал в лыжных соревнованиях», - писал он в автобиографии.

После окончания училища Лапцуй два года работал фельдшером, одновременно продолжая сотрудничество в газете. Как подающего надежды газетчика Лапцуя направили на учебу в Моск- 
ву на отделение корреспондентов газет в ВКШ. После окончания Высшей комсомольской школы в 1956 году Лапцуй вернулся на Ямал, занимал руководящие должности. С 1970 года до конца дней был редактором окружной газеты на ненецком языке «Нярьяна Нгэрм» (Красный Север).

В кабинете Лапцуя в доме-музее висит последний номер газеты «Няръяна Нгэрм» от 19 февраля 1982 года. Этот номер был подготовлен Лапцуем на три четверти. Четвертую часть занимают некролог и стихи на смерть поэта. Ненецкий поэт Григорий Пуйко, потрясенный внезапной смертью друга, написал за одну ночь стихотворение «Енядат пуна» («После тебя»). В нем скорбь и страдание: «Пурга неистовствует, ветер воет, ветер плачет, люди плачут три дня и три ночи». Пуйко заверяет рано ушедшего из жизни друга в том, что память о нем не иссякнет благодаря его поэзии, и что молодые поэты возьмут эстафету развития национальной литературы в свои руки.

При жизни Лапцуя издано на русском и ненецком языках более двадцати сборников стихов и поэм. Первые стихи и рассказы Л. Лапцуя появились на страницах газеты «Няръяна Нгэрм» («Красный Север») в 1951 году. Позже он печатался в журналах «Дружба народов», «Урал», «Сибирские огни», в коллективных сборниках «Земляки», «Небо у ног», «Север поет», «От Москвы до тайги одна кочевка» и др. Первая поэтическая книжка на ненецком языке «Мань Ямалми, вадёд» («Цвети, мой Ямал») вышла в 1960 году.

В 1964 г. Л. Лапцуй был принят в Союз писателей СССР. К тому времени, кроме газетных, журнальных публикаций и книги «Мань Ямалми, вадёд» («Цвети, мой Ямал») в Тюмени вышли из печати сборник «Рассказы о Ямале» (1962) на ненецком языке и сборник рассказов на русском языке «Камень с надписью» (1963).

По тематике рассказы Л. Лапцуя сходны с ранними рассказами чукотского писателя Ю. Рытхэу, нанайского прозаика Г. Ходжера - в них нашли отражение изменения в традиционной жизни согласно новым культурным установкам, сложная психологическая перестройка народов Севера в иных социальных условиях.

Свою первую поэтическую книгу на русском языке (переводчик Л. Шкавро) молодой автор открывает стихотворением «Моя любовь» - в нем звучит признание в беспокойной, деятельной любви к тундровым просторам, зовущим к поездкам на оленях 
сквозь пургу, к тундре, которая с детства научила выносливости, умению «брать любые старты». «Заряжаясь радужным дыханием», герой в поисках новых достижений и побед вновь и вновь отправляется в дальний путь. Жизненная активность героя - это и жизненная позиция автора. Молодой азарт странствий, радость деловых поездок по Ямалу сопутствовали поэту все годы его жизни. «Я всегда в пути» - так названо стихотворение, в котором он сравнивает активность лирического героя, в котором высвечены собственные жизненные реалии, с птицей, пребывающей в постоянном полете. Цель же поездок- освоение мира, обретение знаний: «что-то открываю, что-то узнаю». Он постоянно путешествовал не только по Ямалу, но и по всему северному краю, по всей стране.

Л. Лапцуй стремился охватить взглядом многие темы, вобрать в орбиту своей поэзии как можно больше событий, мест, героев. Ему удалось создать широкое полотно жизни на Ямале, представляющее исторический интерес. Создано оно поэтом-реалистом, согрето живым чувством человека, горячо сопричастного описываемым событиям. Эпичность, образность, символика, притчевость - атрибуты поэзии Лапцуя.

Откликаясь на актуальные проблемы в жизни ненцев, осмысливая их, поэт стремился привлечь к ним внимание окружающих: «Строка моя - / счастливая зарница, / я от тебя хочу лишь одного:/ в сердцах людей/ светиться / волнениями сердца моего» («Моя строка», пер. Л. Шкавро). Это откровенное желание побуждать к действию человеческие сердца в ранней поэзии зачастую приводило к риторизму и дидактике.

В конце творческого пути поэт почти избавился от морализирования, его лирика стала более элегичной.

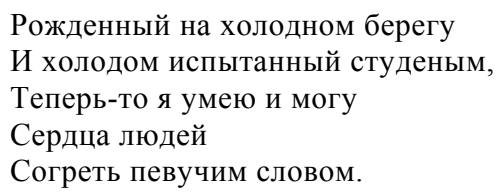

Обрести широкого читателя Лапцую помогли поэты-переводчики с ненецкого на русский. Среди них поэты Наталья Грудинина, которая переводила его стихи в течение двадцати лет, Михаил Яснов, Илья Фоняков, Леонид Шкавро и др.

О влиянии русской поэзии на творчество свидетельствует и тематическая перекличка, и откровенные признания. Кумиром 
для себя Лапцуй избрал Александра Пушкина, как и многие северные поэты. Мастерски используя металогию, ненецкий поэт представил свои поэтические стремления и высоты, к которым устремлялся:

И подумал я, счастливый,
Что березовый хорей мой -
Младший брат тому хорею,
Что у Пушкина в стихах.

(Пер. Н. Грудининой)

В духе своего времени, будучи заложником идеологических установок, Лапцуй зачастую выступал с позиций атеиста и мотивировал поведение героев с точки зрения «разумности-неразумности», но мифопоэтическое сознание ненецкого творца, его вера в шаманизм, мистические силы проявлялись то завуалированно, то откровенно. Сюжет поэмы-сказки «Тёр», например, построен на основе метафизических знаний об обретении шаманской силы и использования ее в жизненно важных для героя и всего народа судьбоносных обстоятельствах.

Отношение Лапцуя к мистике подобно властителю его дум Пушкину, который верил «и снам, и карточным гаданьям, и предсказаниям луны», было неодолимо притягательным, волнующим, завораживающим. В беседах он порой признавался в своих таинственных провидениях, в присущей ему «шаманской силе». Это созвучно размышлениям Гёте: «...Мы блуждаем в таинственной тьме. Нам неведомо, какие силы шевелятся в окружающей нас атмосфере, и в какой степени они связаны с нашим духом, известно одно: есть такие состояния, когда щупальца нашей души протягиваются за ее телесные границы и дарят ее не только предчувствием ближайшего будущего, но и подлинным ее предвидением» ${ }^{4}$. Возможно, именно некое предчувствие близкой смерти подтолкнуло Лапцуя к написанию краткой автобиографии, в которой он как бы подводил итог своей жизни. Тема смерти часто присутствовала в его философических беседах с друзьями. В последних стихах - размышления о бренности жизни:

Между жизнью лечу и смертью.

Жизнь и смерть мелькают, как вехи,

Справа-слева - все незнакомо.

По волнам снеговым, несметным

На простор необъятный въехав, Мчит упряжка по льду морскому.

(«По следу», пер. Е. Пудовкиной) 
Жизнь поэта оборвалась внезапно, не позволив написать Главную книгу. Об этой книге он не раз говорил как жене Елене Сусой, так и собратьям по перу - Роману Ругину, Григорию Пуйко. В музее-квартире в Салехарде хранится план предполагаемых поездок по Ямалу для сбора материала будущей книги. Начальные пункты маршрута - озеро Ямбо-то, Новый Порт - места, где прошло детство поэта.

Представить образ ненецкого поэта, раскрыть его характер, глубже осмыслить волновавшие его проблемы, близкие его друзьям и актуальные для всех ненцев, могут помочь воспоминания современников, записанные мною во время бесед с ними в Ненецком АО и на Ямале в 1984-85 гг.

Ненецкий поэт из Нарьян-Мара Алексей Пичков отмечал контактность и доброжелательность, гостеприимство и активность Лапцуя: «Это был очень жизнерадостный, веселый человек, подвижный, как ртуть». Пичков отметил своеобразие его речи: «Он говорил по-ненецки красиво, как шаман. Интересные обороты в его мыслях завораживали».

Хантыйский писатель Роман Ругин кратко, но объёмно охарактеризовал:

«Леонид был активным, с необычайно широким кругом интересов. Ему были свойственны постоянная неудовлетворенность собой, своим творчеством, исключительная работоспособность».

Большинство собеседников отмечали доброжелательность и заботу, бескорыстную помощь, надежность слов и крепость обещаний Лапцуя. Он относился к своим обещаниям, как ненцы относятся к клятве: за невыполнением придет обязательное наказание. Журналист Галина Тахоля воспоминания о Лапцуе сопровождала цитатами из его стихов: «Это был добрый, отзывчивый человек. Он с отеческой любовью относился к окружающим, мог “сердцем вскрикнуть, увидав беду чужую” и “вспыхнуть гневом, если друга кто обидит”».

Современник и друг Лапцуя поэт Пуйко вспоминал о встречах с ним то в Яр-Сале, то в Салехарде, во время которых они читали новые стихи, делились планами на будущее и спорили. По его словам, Леонид был всегда подтянут, жизнерадостен, настроен оптимистически, делился своей энергией и знаниями. «После встречи с ним во мне надолго оставался заряд бодрости», - благодарно отзывался Геннадий Пуйко.

Духовное развитие ненцев было в сфере постоянных забот Лапцуя. Он беспокоился о молодых поэтах, оказывая всесторон- 
нюю поддержку. Поэт Прокопий Явтысый во время беседы о Лапцуе подчеркнул значимость его в своей творческой судьбе: «В 1969 году в городе Нарьян-Маре он отвел меня в местную редакцию и порекомендовал напечатать мои стихи, познакомил с поэтами-переводчиками. Особенно я признателен за знакомство с Михаилом Ясновым, которое переросло в творческую дружбу, в результате которой вышла в свет моя книга "След аргиша"».

Лапцуй с 1973 по 1981 год руководил группой начинающих литераторов.

Напряженная, многокрасочная жизнь с мечтой и делами, направленными на обустройство Ямала и его жителей, самобытное творчество Л. Лапцуя - весомый вклад в национальную копилку. С другой стороны, приобщение к его жизни и творчеству один из путей раскрытия этнопоэтики лиро-эпических произведений поэта, постижения национальной самобытности, картины мира ненцев.

\section{"С рожденья песня входит к нам в сердца" (О ненецких песнях и стихах Лапцуя)}

Хранить песни, «спетые дедами в их минувшей судьбе»,творческая установка, постоянный девиз Лапцуя. С ним он обращался и к взрослым, и к детям. Юного героя поэмы «Эдейка» поэт просит беречь свой язык, чтобы сохранить вместе с ним и песни народа. Песня сопровождает ненца от рождения до конца жизни в прямом смысле. Личную песню для младенца сочиняют родители вскоре после появления на свет. Эта детская песня нюкубс - сопутствует ему до совершеннолетия или до той поры, когда человек будет способен сам сочинить себе взрослую личную песню. Хотя детская личная песня сочиняется родителями, поется она чаще всего от имени ребенка, чтобы он мог запомнить и сам напевать. С годами он может дополнять ее своими словами. Взрослую личную песню ненец тоже может разнообразить словами, углубляя содержание, но не менять ее полностью, изменивший этой установке - «непорядочный» человек, «свою линию не держит». В отличие от некоторых других северных народов, например, чукчей, у которых одобряется, если личную песню запел кто-то другой, то значит уважает хозяина, ненцы не могут петь чужую взрослую личную песню при ее хозяине. Можно лишь услышав и запомнив мотив, передать ее другим, назвав автора-владельца. Детские личные песни содер- 
жат наблюдения о характере ребенка, мечты и чаяния родителей. Обычно мальчику желали вырасти тружеником: хорошим охотником, оленеводом, рыбаком, а девочке - стать искусной мастерицей, работящей, хорошей хозяйкой.

Личные песни, песни-импровизации - это думы вслух: человек невольно как бы выдает свои тайны. Немногословный, приученный к сдержанности юноша, например, только в песне может поведать о своих сокровенных любовных переживаниях, девушка может даже назвать имя возлюбленного.

Свои первые стихи, которые Вэсако начал сочинять в детстве, по его воспоминаниям, были личными песнями для оленят. Мальчик подходил к самому смирному олененку и начинал петь бесхитростную хвалебную песню: «Мой прирученный бычок, хороший, добрый олень, самый лучший в стаде, ты красив и статен. А мама у тебя самая ценная и красивая».

О роли песни в жизни ненца поэт очень выразительно и точно написал в стихотворении «Прерванная песня» (пер. А. Каныкина): «С рожденья песня входит к нам в сердца, а в смертный час стоит у изголовья». В этом стихотворении песня-импровизация, которую поет прославленный охотник у смертного одра, выступает в роли утешительницы, помогает сдержать стоны, недостойные мужчины, попрощаться с родными просторами тундры.

Лирическую песню-импровизацию может исполнять не только автор. При этом исполнитель должен сообщить, чья это песня. Если имя автора утеряно, а из содержания не понятно, кто ее сочинил, то необходимо прокомментировать, кто, по его мнению, мог быть автором песни.

Личные песни, песни-импровизации, а также ярабц и сюдбабц - бытовые и героические песни - были живительным источником для поэта всю жизнь. Их он собирал, обрабатывал, печатал в газете «Нярьяна Нгэрм», в сборниках фольклора. Они формировали поэзию Лапцуя.

Он писал в основном белыми стихами, в которых использовал стилистические приемы ненецких музыкально-поэтических произведений - звукоподражание, аллитерацию, повторение в стихотворной речи одинаковых согласных звуков, и ассонанс, повторение одинаковых гласных звуков.

В стихотворении «Родовой костер» Лапцуй с помощью звукоподражания, аллитерации и ассонанса выразительно передал шум и свист ветра, а переводчик Я. Козловский сохранил эти 
приемы и в русском варианте: «Он свищет и рыщет в продрогшем краю / Живую он ищет добычу свою».

Звукоподражание и аллитерация использованы поэтом для описания разбушевавшейся стихии в стихотворении «Тише ты, Пур-река». В нем звуки $p$ и $m$, сочетания кр., гр., пр. имитируют перекатистый яростный шум.

\section{Тише ты, Пур-река, \\ Скрученная, как трос! \\ Белые, как снега, \\ Пряди твоих волос.}

«Стих Лапцуя пламенеет, как лисий мех на снегу, мчится за упряжкой, клекочет чайкой над обской волной, оборачивается тенью совы», - отметила воздействие поэзии специалист по ненецкому языку Е. Самойлова 5 .

Стихи Лапцуя очень музыкальны. Их ритмическое строение в соединении с особой фонетической фактурой и естественной выразительной интонацией определяет плавное гармоническое звучание. Перекличка звуков усиливает их образную значимость, эмоционально-экспрессивную окраску поэтических произведений.

По окружному радио, в клубах, в школах звучат песни на слова поэта-фольклориста. Первая песня на стихи Л. Лапцуя «Еду за любимой» появилась в 1962 году в сборнике «Северные россыпи» (напев (музыка) Е. Сусой, нотная запись сделана П. Кравцовым). Песня «Еду за любимой» на ненецком языке часто исполнялась фольклорным ансамблем «Сэрасэв».

Большинство песен на стихи Лапцуя написаны ненецким композитором Семеном Няруем. Давняя творческая дружба связывала поэта и композитора. Л. Лапцуй, будучи старше Няруя на 14 лет, давал наставления музыканту, порой сомневавшемуся в правильности избранного им пути популяризации и развития народного музыкального искусства, поддерживал в нем уверенность в творческих силах и способствовал расширению тематики его песен и танцев. В творческом содружестве поэта и музыканта были созданы песни «О матери», «Салехард», «Орленок» и др. О действенной поддержке Лапцуем своего друга-композитора свидетельствует и очерк «Пензер ${ }^{6}$ звучит над тундрой», написанный им и опубликованный сначала в местной прессе, а позднее - в сборнике «Сияние Севера» ${ }^{7}$. В очерке наглядно представлено особое восприятие поэтом окружающей природы, душевная близость с ней. Его стихи, положенные на музыку - отзвук многокрасочной, стремительной жизни тайги и тундры. В весенних 
звуках говорливого ветра и пенистых волн многоводной Оби он слышит песни, трогательные, наполненные пульсирующей мыслью. «Тише, прислушайтесь, о чем эта песня... Может быть, река поет о радости встречи, о любви и поцелуях, а может, о том, как зализывают свои раны звери или как плещутся в воде выводки утят... Вы слышите, ведь это звучат мелодии песен моей родины, мелодии, которые Обь на всем протяжении собирает как россыпи драгоценного жемчуга. В низовьях реки эти мелодии сливаются в одну широкую и раздольную песню. И летит эта песня крылатым лебедем над стылой тундрой и глухой тайгой».

Одушевляя песню, Лапцуй воспевал её, делая героиней описываемых событий. В стихотворении «Песнь о песне» перед читателем предстает в воспоминаниях зрелого человека светлый образ девушки, созданный благодаря ласковой, упоительной песне:

\begin{abstract}
Нежно и плавно на волнах воздушных
Рыбой серебряной песня плывет -

Чайкой незримой рванулась в полет.

Песня легка и светла и тонка, как пушинка,

Как летнее небо над Обью, светла.
\end{abstract}

(Пер. Л. Гладкой)

Для ненецких песен характерны разнообразие стихотворного размера, манеры повествования и единый стилистический прием - постоянный повтор отдельных слов и предложений. Этот стилистический прием нередко использовал Л. Лапцуй в своих стихах. Повтор-параллелизм, прием фольклорной поэтики, в стихотворении «Язык ненцев» создает атмосферу доверительности и подчеркивает музыкальность, напевность ненецкого языка, которые сумел сохранить переводчик.

Язык наш веками отточен,

Как дедовский нож на бруске.

Язык наш без промаха точен,

Как пика в умелой руке...

Язык наш суров и не пышен,

И нет в нем прекраснее слов,

Чем эти, что с детства мы слышим:

Пастух, рыболов, зверолов.

Три слова скажу лишь, а вроде

Как целую песню спою.

Язык наш веками отточен

Язык наш без промаха точен! 
Таков он и в сказках Ямала,

В которых сквозь посвист ветров

Проходит удачливый малый -

Пастух, рыболов, зверолов.

Три слова - рассказ о народе,

Что выжил в студеном краю.

Язык наш веками отточен,

Как целую песню спою.

(Пер. В. Афанасьева)

Стилистические и композиционные приемы фольклора Лапцуй использовал нередко, в частности, в цикле стихов «Четыре девушки», в поэме-сказке «Тёр».

Лапцуй был искусным исполнителем ненецких песен, о чем вспоминали в беседах современники. Мог неожиданно преображаться в героев песен, и слушатели видели перед собой то необыкновенно красивого сказочного богатыря, то злого и уродливого врага, то волшебника-шамана. Таким он предстал, например, в рассказе специалиста по ненецкому языку Р. Канюковой. Ей запомнилась встреча с Лапцуем в Ленинградском педагогическом институте в начале 60-х годов во время ее учебы там. Он приехал с Ямала к учившейся в институте жене Елене Сусой и организовал литературный вечер для студентов, на котором не только читал стихи, но и пел ненецкие песни. «Мы, как завороженные, долго слушали его. Он мог, как Тыко Вылка, своим пением увлечь слушающих, передать голосом настроение героев песни и даже имитировал женские голоса», - вспоминала Р. Канюкова.

Творческий подход Лапцуя к народной песне обогатил как содержание, так и форму его поэтических произведений. Привнес в них национальный колорит, способствовал сохранению устно-поэтической образной системы.

\section{«По следу времени»}

Создать поэтические картины жизни ненцев в многовековой ретроспективе, раскрыть перед читателем их мировидение при отсутствии письменных источников поэту было непросто. Историческая судьба народа глубоко волновала его, он предпринимал поиски корней, значимых событий. Одно из них - длительное сопротивление под руководством Ваули из рода Ненянг несправедливому отношению к бедным тундровикам со стороны вла- 
стей, собиравших налоги, и против владельцев больших оленьих стад, использовавших наемный труд. О Ваули, что с группой единомышленников угонял часть большого стада и раздавал нуждающимся, стало известно в 20-х годах XIX века. Гуманные идеи о справедливости и храбрость народного героя привлекли в его отряд значительное количество ненцев. Местные богачи настолько боялись его, что долго мирились с его набегами и не доносили властям в Обдорске . $^{8}$

Лапцую как собирателю фольклора были известны созданные ненцами легенды, песни и сказки о Вавлё (Ваули) - защитнике народа. В них он чаще всего представал богатырем, обладающим необыкновенной силой: легко разрывал крепко сплетенный аркан для ловли оленей, побеждал в борьбе до десяти взрослых и крепких мужчин. Обладал Вавлё и волшебной силой - мог, например, превратиться в комара ${ }^{9}$.

О мужественном и храбром герое Лапцуй написал немало поэтических строк. В них он становился на сторону борца за справедливость, объяснял объективные причины его популярности у ненцев. «А кто людей гнетёт, / заслуживает тот / аркана и стрелы», - писал он в стихотворении «Мыс Вавлё» (пер. В. Гордиенко). Поэта привлекало бескорыстие народного героя, который никогда не брал себе оленей из угнанных стад: «Народу навсегда / Хотел отдать стада / И в справедливом зле / Карал хозяев стад». В стихах Вавлё предстает героем, имя которого увековечено не только в фольклоре, но и в географических названиях, например, в память о нем назван мыс Вавлё.

Всматриваясь в прошлое, Лапцуй обращался к суровым испытаниям в годы Великой Отечественной войны 1941-45 гг. Он испытал на себе тяготы трудной военной поры в тылу, когда десятилетним мальчиком трудился во взрослой бригаде рыбаков, заменяя больную мать. В стихотворении «Память» (пер. А. Каныкина), написанном от лица мальчика - бойца трудового фронта - представлена картина самоотверженной помощи ненцев боевому фронту. Сутками напролет тяжелой пешней долбит «железный» двухметровый лед, изнемогая от усталости, голода и бессонницы десятилетний мальчишка, стараясь не отстать от взрослых, видит невыдержавших тяжелой нагрузки, которые «обледенев к утру», не могли проснуться.

Тема военного детства, основанная на собственном жизненном опыте, многократно в разных вариантах повторялась в творчестве Лапцуя. В стихотворении «Прошло мимо» (пер. А. Каны- 
кина) мы вновь встречаемся с мальчиком, который встает рано и ежится от озноба, поскольку мать подает ему еще невысохшую рабочую одежду. Но ему льстит, что завтракать мать и младшие братья не начинают без него, кормильца, заменившего отца, ушедшего на фронт. Вместе с рыбаками он то гребет, то тянет сети, но не жалуется, хотя «продрог до костей», «ладони ноют болью острой / натертые до пузырей». Сны маленького героя наполнены волнениями, пережитыми во время изнуряющей недетской работы. Автор словами измученного тяжким трудом и невзгодами ребенка осуждает затеявших эту злодейскую, изнурительную войну: «И кулаком грожу кому-то:/ “Будь проклята война!”»

Проникнуты гордостью поэтические строки Л. Лапцуя о сражавшихся на фронтах земляках, которые были меткими стрелками, умелыми проводниками на северном фронте.

Отдавая дань памяти погибшим ямальцам, лирический герой стихотворения «Слушаю тебя, Земля!» (пер. М. Яснова) привез на Мамаев курган родную землю- «комочек ямальской скупой мерзлоты»: «И, встав на колени, подняться не смея, / Шепчу на ненецком своем языке я: / “От Карского моря, от тундры родной / Примите поклон - материнский, земной”». Одухотворяя и стихии, и природу, герой передает поклон и «от вьюжной метели, под ветром летящей», и «от каждой травинки, растущей весной».

Поэтическое путешествие «по следу времени» возвеличивает мужество и стойкость ямальцев, их находчивость и терпение, способность на беззаветный труд и ратный подвиг.

\section{«Стали к земным подбираться кладам»}

Значительное место в творчестве Лапцуя занимает тема промышленного освоения Ямала. В стихах и поэмах он изобразил тернистый путь покорителей Севера, от первого десанта геологов, которые «стали к земным подбираться кладам», до строительства городов. Подобно Тыко Вылке, который сопровождал исследователей Новой Земли, участвовал в экспедиции Русанова, пятнадцатилетний Леонид Лапцуй летом 1947 года сопровождал сейсмическую партию. Он прошел с геологами восемьсот километров, провел отряд до Мыса Каменного. Это была школа испытания на выносливость и выдержку, которая не только осталась в памяти, но и способствовала творческому вдохновению: «Товарищи по первому отряду, / С которыми по трассе я плечом / К плечу сражался с тундрою когда-то, / Навек остались в сердце 
вы моем» («Трасса», пер. А. Каныкина). Геологи поражали подростка своими знаниями, выносливостью и верой в открытие подземных кладовых природного топлива, которое изменит жизнь холодного и сурового края.

В поэме Лапцуя «Сполохи Севера» (пер. А. Каныкина) прообразом одного из главных героев Волжина стал известный геолог, лауреат Государственной премии В. Подшибякин. Это взволнованный рассказ о психологической перестройке ненцев в связи с промышленным освоением края, о беспокойной судьбе молодежи, о дружбе и взаимовыручке людей в суровых условиях, о самоотверженном труде геологов.

Поэма начинается с пролога - описания тягостного раздумья, в которое впало откочевавшее вглубь тундры коренное население, испугавшись геологов со своими буровыми, нарушивших тишину тундры и вековые обычаи: «Где видано, / чтоб ненец тундру / железом острым ковырял?»

Сюжет поэмы развивается вокруг истории одной семьи, жизнь которой резко изменилась из-за встречи с геологом. Мудрый оленевод Вэрья, умеющий читать «все мысли северной природы», готовит своего сына Папалю в потомственные оленеводы: учит языку тундры, закаляет характер, чтобы он стал «глазами и чутким сердцем старика». «Какой же ненец ты, / коль не познаешь крик звериный, / не сможешь прочитать следы?»напоминает постоянно отец своему наследнику.

Но ритмы нового времени внесли кардинальные изменения в судьбу сына. Однажды Вэрья с сыном в пургу спасли геолога. Они подружились с Волжиным, оказавшимся начальником геологической партии. Папаля, увлеченный рассказами поисковика о романтике своей профессии, по его совету, несмотря на возражения отца, поехал учиться в институт. Когда молодой специалист вернулся к «отческой земле», Волжин доверил ему отряд геологов. Папаля с рвением принялся измерять просторы тундры буровыми вышками.

Для Вэрьи дело сына кажется кощунственным, нарушающим традиции, поскольку никогда не было, «чтобы сын оленевода / Тревожил сон земных богов». Он посоветовался с другими старцами, и те включились в борьбу с нарушителем законов тундры. Вступив на тропу войны, защитники древних традиций решили применить для него жестокое наказание: раздеть, связать и поставить под ветрами тундры, чтобы снять грех с него и избавиться самим от возможного наказания за его неподобающее об- 
ращение с тундрой. Но Папаля был смел и удачлив, жил верой в «грядущий светлый день Ямала», надеялся развеять злобу старцев результатами своих дел. И действительно, костер дружбы у открытого им газового месторождения, когда «огонь светящеюся птицей взмыл, осветив снега и льды», рассказы геологов об иной жизни заронили сомнения в душах старцев-оленеводов. И Вэрья «с нелегкою душой / навек простившись с жизнью прошлой, / поехал к сыну — к буровой».

Поэма Лапцуя «Победившие смерть» посвящена ямальским геологам, сражавшимся со стихией в Карском море. В основу произведения, как отмечает автор в эпилоге, положен «истинный случай». Развернутой экспозицией, рассуждениями о жизни и смерти, рассказами о причудах сурового Карского моря, автор подготавливает завязку напряженного сюжета - выход трех молодых геологов в море. Предваряя встречу их со стихией, поэт обращает внимание читателей на то, что героям, осваивающим Север, не известны проверенные веками наблюдения ненцев.

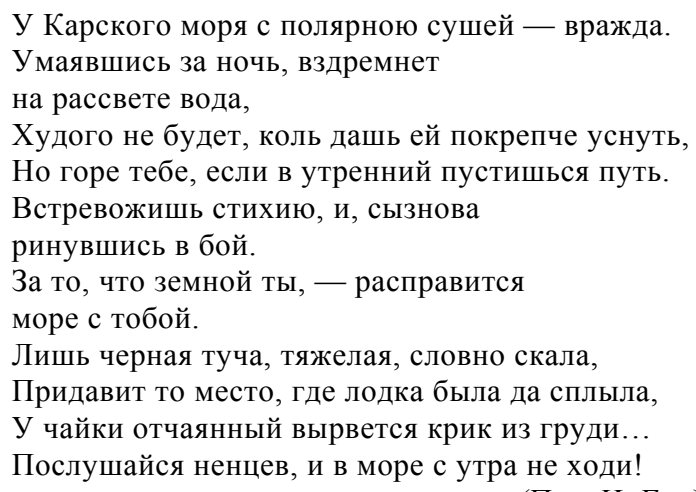

(Пер. Н. Грудининой)

Незнание многовековых наблюдений ненцев над изменениями в природе привело геологов в «лапы» разбушевавшейся вновь стихии после утреннего «затишья». Борьба со стихией высветила характеры героев. Поэт убедительно и ярко нарисовал людей, поведение которых не совпадало с убеждениями и поведением ненцев. Не свойственно ненцам, например, малодушие, желание самому покончить с собой, как это хотел сделать поисковик Георгий, вытащив пистолет. «Нет, проклятая стихия, не возьмешь меня живьем!» - кричит он. Для ненцев такой разговор со стихией 
невозможен. Вместе с тем, поэта удивляют и восхищают выдержка, взаимовыручка, стойкость и находчивость поисковиков.

К теме промышленного освоения Ямала, роли ненцев в изыскательском деле Лапцуй обращался многократно, развивая их, отражая постепенно меняющиеся настроения и взгляды коренных жителей. В поэме «Под звездами Ямала» (пер. Л. Сорокина) ненецкий геолог, командир отряда Тусида уже не сталкивается с недоброжелательным отношением пожилых людей к изыскательской работе, внимательно прислушивается к их советам и старинным преданиям.

Поэта глубоко волновали проблемы столкновения разных культур, сохранения былого, накопленного ненцами жизненного опыта в изменившихся жизненных условиях. Тусида, имя которого означает «человек без огня», ищет «огонь»- газовое месторождение. Он повел отряд к сопкам, где от молний зажигалась земля, и «черный дым вставал столбом / и небеса коптил годами». Когда-то здесь оленеводы перед кочевкой на дальние расстояния приносили жертвы огню, поскольку считали его священным. Препятствия на пути отряда - своеобразное сопротивление вмешательству в жизнь природы. Одолеть их помогают лишь знания и опыт Тусиды как коренного жителя. Когда поисковиков «в капкан снегов поймал разбушевавшийся Ямал» - вездеход заглох, мороз и ветер усиливались, запасов еды не оказалось, а жилье было далеко - Тусида как умелый коренной житель тундры не позволил геологам надолго останавливаться, вел их несколько дней подряд. Он оттаивал в руках куски оленьего моха - ягеля, жевал его и предлагал это делать молодым приезжим геологам, «чтобы заглушить на время голод». Когда же пурга окрепла, набрала мощь, а искатели выбились из сил, Тусида предложил построить «куропачий чум» - рыть в сугробе укрытие. Отыскать вертолетчикам занесенный снегом отряд помогла собака Хорти, которую Тусида когда-то нашел полуживой и отогрел на груди. Она бегала вокруг вертолета, когда его готовили к полету, и как только он поднялся, побежала из поселка в тундру. Вертолет со спасателями поднялся и полетел вслед за возвратившейся к «куропачьему чуму» собакой. Хорти отыскала своего хозяина: «И вдруг — застыла на бегу, / И вдруг — рванулась к косогору, / И роет лапами в снегу, / И заползает с визгом в нору. / Рывком - к хозяину на грудь, / Чтобы лицо его лизнуть!» Такая тесная, телепатическая связь животного и человека, способствующая спасению, — не нова для ненца. 
Тусида открыл газовое месторождение, установил буровую вышку и зажег «великаний костер», вокруг которого люди радовались тому, что «человек без огня» дал начало огненному роду, «и будут внуки вместе с ним гордиться именем своим». Безымянный мыс, на котором находилось месторождение, Тусида назвал Огненным.

Вслед за геологами на Ямал, в Тюменское Заполярье приехали строители, и те, кому предстояло осваивать открытые подземные богатства. Лапцуй внимательно отслеживал все исторические события, происходившие в жизни ненцев, а героев реальной жизни превращал в прототипы действующих лиц своих произведений. В центре поэмы «Пути-дороги» (пер. М. Яснова) - участники строительства города газовщиков Надыма. Сибиряк Леонид Смышляев и ямальский пастух Василий Ламдо встретились на грандиозной стройке, отличились успехами в труде, о чем писала местная пресса. В поэме Лапцуй образно представил, как зарождалась крепкая мужская деловая дружба между русским героем-строителем Смышляевым и никогда не бывавшим до этого на большой стройке Ламдо, как Леонид учил юношу нетрадиционной профессии электросварщика. Способный и старательный ученик не подвел терпеливого наставника - заслужил звание «мастер-золотые руки». Судьба ненецкой молодежи в новых жизненных условиях тревожила Лапцуя, и он предъявлял в своей поэзии образцы, как вписаться в новую жизнь, не растеряться и не потеряться в ней.

Волновало поэта и сохранение природы Севера, которую он своим мифологическим сознанием одухотворял. В стихотворении «Дыхание земли» (пер. А. Каныкина) - размышления о потревоженной природе, невольно загубленной ради чего-то нового в жизни людей. В Пуровской тайге, в диких и угрюмых местах, «где не пел костер в холодной мгле ночей» и не звучал человеческий голос, пробурили геологи вечную мерзлоту, и «продремавший долгий век под Пяковской землею» газ вырвался «лавиной огневой». Выпущенный на свободу огонь стал бедствием для вековых деревьев:

Клокочет долгий звук у них в груди

Подобьем человеческого стона.

Потрескивает рыжая смола,

Сгорают кедры с молчаливым плачем.

Земля, что их когда-то родила,

Вдруг обожгла дыханием горячим. 
Катился вглубь тайги гудящий вал,

Как будто жадно обнимался с веком.

Стволы и лица жадно целовал

Огонь, освобожденный человеком.

Потрясенный увиденной картиной страданий многовековых кедров, лирический герой пытается философствовать о цикличности жизни, найти компромисс и оправдать необходимость нарушений гармонии человека и природы: «Что делать, если у детей земли / Всегда сопряжено рожденье с болью».

Промышленное освоение Севера сопровождалось и продолжает, к сожалению, сопровождаться нарушением экологии края: порчей ягельного покрова на оленьих пастбищах, вырубкой вековых деревьев в тайге, загрязнением рек и озер, сокращением числа зверей и птиц.

Лапцуй в своих стихах и поэмах пытался наглядно убедить покорителей Севера быть чуткими и заботливыми к окружающей природе. В стихотворении «Ночной гость» (пер. Н. Грудининой) потревоженный шумом медведь вылез из берлоги и приблизился к костру полюбопытствовать. Один из нефтяников в охотничьем азарте схватился за двустволку. Медведь же вырвал ружье, разломил пополам и спокойно ушел от костра, как бы приговаривая: «Не яритесь, мол, люди, зря!».

Две резко контрастные картины нарисовал Лапцуй в стихотворении «Харасавэйко» (пер. Я. Козловского). Сначала перед читателем - красивая и чистая, богатая рыбой речка Харасавэйко. Радующая и притягивающая к себе. Затем - та же речка, но двадцать лет спустя: обезображенная мазутом, мрачная, приводящая в уныние и отпугивающая. Поэт-гражданин обращается к начальству Тюмени со словами осуждения, настойчиво советует позаботиться о сохранении природы.

Стихи Лапцуя о промышленном освоении Ямала позволяют наглядно представить жизнь полуострова в 60-70-е годы XX века, уяснить проблемы, которые волновали его и современников.

\section{Поэзия труда}

Художественное осмысление трудовой жизни позволило Лапцую создать ряд стихотворений и поэм о традиционных и новых для ненца профессиях, о людях, владеющих ими, об отношении ненцев к труду. Образ труженика тундры - оленевода, 
охотника, рыбака - в его произведениях многокрасочен, отражает народные представления об этих профессиях.

Как сын оленевода, Лапцуй досконально знал эти традиционные занятия, их трудности и радости. В стихотворении «Пастух» (пер. Н. Грудининой) он утверждал: «Чтоб стать пастухом, и наука нужна, и уменье», поскольку «не каждый сумеет всю тундру пройти до конца, и денно, и нощно шагая по тропам оленьим». Потому и тренируются дети с малых лет в беге, быстрой ходьбе как со сверстниками, так и с взрослыми, помогая им во время дежурства в стаде.

Нелегко справиться с оленьим стадом, необходимо приручить оленей, узнать их нрав. Знания о поведении домашних оленей, о специальных приемах обращения со стадом во время выпаса передаются из поколения в поколение с помощью наставлений, наглядных примеров, включая в фольклор. Так, пытливый и наблюдательный оленевод умеет определить лидера в стаде, подобрать вожака для упряжки: «Белолобого оленя / Я поставил вожаком - / По оленьему веленью / Все за ним идут гуськом» («Аргиши», пер. Б. Попова).

У оленевода смелое и доброе сердце. Во время весенней распутицы он бросается спасать попавшего в беду новорожденного олененка: «Снимет малицу и греет сосунка - / Вот какая, брат, душа у пастуха» («Пастух»).

И пастух, и охотник в тундре не могут обойтись без добротной нарты, сделанной без единого гвоздя из твердого кедрача или березы. Важно овладеть секретами мастерства, чтобы не получилась она «хромой». Не менее важен и хорей, шест для управления оленями. Лирический герой стихотворения Лапцуя «Хорей» (пер. В. Афанасьева) с чувством восхищения рассказывает о своем дедушке-умельце, дела которого известны многим ненцам.

\footnotetext{
Мой дед с одним ножом, без топора, Оленьи нарты мастерил умело.

Легко делил он ствол березы белой, Как хрящевую спинку осетра.

Пока закат над тундрой догорал И солнца луч сверкал, уже не грея, Дед создавал упругий шест хорея, И славен был он тем на весь Ямал. Храню я с детства памятный хорей, Березовый, подаренный мне дедом, Легко приподниму его, и следом Олени встанут в памяти моей.
} 
Ловкость мастера подчеркнута поэтом знанием тонкостей изготовления, четкими навыками, временем изготовления хорея, «пока закат над тундрой догорал и солнца луч сверкал уже не грея», т. е. достаточно коротким осенним днем.

Поэт часто размышлял о древней профессии оленевода, о том, что она потеряла былой престиж у молодежи. В прошлом же была уважаема всеми ненцами: «Когда-то здесь был что ни житель, / то бравый пастух, / Ему вся округа отвесить поклон торопилась» («Наше стойбище», пер. Н. Грудининой). Причиной волнений за традиционную профессию было то, что в 70-е годы XX века обучавшиеся с раннего возраста в круглосуточных детских садах, в школах-интернатах дети вырастали неподготовленными к сложному кочевому быту и требующему специальных знаний и умений оленеводству. Поэт отмечал, что на празднике оленевода молодые люди с гордостью говорят: «Я сын пастуха!», но сами не умеют даже запрячь оленей. Чтобы продолжить династию оленеводов, у них нет ни умений, ни закалки, ни сноровки. С горечью он восклицал: «А жаль мне порой, что за множеством дел и забот / Старинные наши ремесла не всяк уже ценит, / Что труд пастуха величаем единожды в год, / Когда он для нас на рогатого упряжь наденет» («Наше стойбище», пер. Н. Грудининой).

Среди занятий ненцев, издревле обеспечивавших выживание в суровых условиях - охота. Умелый охотник знает, как «распутать» след, не испугаться, «если рядом, рыкнув грозно, на дыбы встает медведь», догнать убегающего зверя «то ползком, а то прыжком», без страха прыгнуть за ним с обрыва, пролезть в щель за росомахой. По мнению Лапцуя, настоящего охотника можно узнать «по сноровке, по походке, / по уменью жечь костер... / Весь он крепкий, ладный, ловкий, / По душе ему - простор». На такого охотника, у которого и «взгляд отточен, как кинжал», закаленного походными условиями, хотелось бы ему быть похожим («Охотник», пер. В. Фалея).

Первые удачи юноши на охоте не оставались у ненцев незамеченными - его посвящали в эту профессию. Об этом пишет Лапцуй в стихотворении «Возвращение с охоты», где степенную радость по поводу своей удачной охоты на песцов выражает в песне молодой человек. В ней «воздает отчей тундре он хвалу, и оленей, как друзей, благодарит». Особое волнение вызывает у него то, что «сегодня у костра, по обычаю отцов, он охотником при всех должен быть провозглашен». 
О бесстрашии и мужестве морских охотников узнаем мы из стихотворения «Кладбище тайн» - так именует поэт штормовое Карское море, поглотившее немало ненецких охотников на морских зверей. Только сильные духом и умелые охотники не страшатся отправляться на «ледяную планету» - так называли ненцы море в народных легендах. В борьбу с водной стихией жители Ямала вступают не только на море, но и на реках, по берегам которых располагались раньше стойбища, а теперь поселки. Особенно опасны и свирепы реки в половодье. Они смывают с берегов жилища, губят все живое.

Труд рыбака, как и труд оленевода, морского и тундрового охотника, хорошо знакомый поэту, не обойден его поэтическим вниманием. Об упорстве рыбаков, которые продолжают добывать рыбу, хотя «волны рыщут, точно волки, по реке», об их смелости и силе, помогающим удерживать лодки и забрасывать невод в ветреную погоду, прыгать в ледяную воду, чтобы вытащить невод, наполненный рыбой, на берег, поэтически рассказывает Лапцуй в стихотворении «Лов на Оби» (пер. Г. Гампер).

\section{«Земля моей любви»}

Поэзия Лапцуя наполнена художественными образами природы ямальского полуострова. Острый, наблюдательный взгляд, умение вслушиваться в звуки жизни, особая, мистическая связь с окружающим миром, а также фольклор позволили поэту нарисовать яркие, выразительные картины. Символическое значение некоторых аспектов пейзажей расшифровать непросто. Пейзаж может, например, вдохновлять к созданию глубоко мистической атмосферы.

Пейзаж в творчестве Лапцуя пронизан своеобразием мировоззренческого восприятия окружающего мира как дома. Это сакральное пространство, соединяющее земную жизнь с небесной сферой и с подземным миром. Описание природы наполнено глубокой внутренней эмоциональностью и самобытностью. Пейзаж, воспроизведенный в поэзии Лапцуя, подобен «говорящей живописи». Герой ощущает свою равновеликость природному мирозданию. Через природу поэт выражает состояние души человека, глубокую внутреннюю эмоциональность и самобытность.

Особенно притягательны для поэта весенние пейзажи, поскольку, по его признанию, приход весны пробуждает в нем творческие силы, светлые надежды. Природа выступает как живое твор- 
ческое и духовное начало. Первые признаки весны - это почти незаходящее солнце, белые ночи:

\author{
Задымился сугроб, \\ Будто горный хрусталь, \\ Отражая огни зеркалами, \\ Ослепительно блещет волнистая даль \\ И в глаза мне стреляет лучами. \\ То озябшую землю - родную сестру, - \\ Возвратясь согревает светило.
}

(«Белье ночи», пер. В. Фалея)

В восприятии ненцев солнце как архетип - женского рода, потому и согревает «родную сестру» - «озябшую землю».

Своеобразным апофеозом пробуждения природы является стихотворение «Весна» (пер. Н. Грудининой). Олицетворяя природу, а с нею и времена года, поэт весну представляет необыкновенно активной сущностью с задорным и буйным нравом, а ледоход - «шальной битвой вьюги и воды».

Свои ощущения могущества и красоты весны поэт переносит в размышления о возможной гармонии в жизни людей - он слышит «её призыв к единству на планете, / И мнилось мне все стойбища на свете / Уже в семью большую сведены». Как весенние ручьи сливаются воедино, объединятся, по его мнению, и народы.

Весеннее солнце, долгожданное после полярной ночи «полотнищем цветным» сияет над тундрой «полусонной». Оно одухотворено поэтом как доброе и светлое начало, приносящее радость: «Оно меня в своих лучах качало, как в люльке разукрашенной, цветной» («Доброе утро», пер. Е. Пудовкиной).

В стихи поэт переносит не только своё восприятие природы, в них нашли отражение проникнутые радостью весенние и летние песни-импровизации ненцев, которые, по его мнению, «навеяны свыше». И звенят сотни этих песен «у неба в устах».

Наполнены бодростью, радостью, многоцветьем красок картины летней природы. Для эмоционально сдержанных ненцев такие всплески необычны - в свои ощущения природы они стараются не посвящать окружающих. Лапцуй как бы выводит во внешний мир глубоко скрываемую ненцами нежность по отношению к природе, красочно рисуя с помощью ласкательных эпитетов и олицетворения трогательный дар летней тундры - цветы:

Хрупкий, на тоненькой ножке куличьей,

Вот он, полярный цветок-невеличка, 
В розовой шапочке из лепестков

Смотрит он в белую рябь облаков.

(«Цветок Севера», пер. Н. Грудининой)

Летний цветок - символ «оттаивания душ» в это мимолетное, краткое, благотворное для мажорного настроения время года - соединяет сердца молодых, приближает свадьбы, а с ними и продолжение рода, что было всегда актуально, первостепенно в жизни ненцев.

Создавая картины природы и человека в ней, поэт стремился обратить внимание на извечную гармонию их сосуществования. Юноша, герой лирического стихотворения «У водопоя» (пер. Н. Грудининой), возвращаясь с охоты «зеркальным утром вдоль речных извилин», полон надежд и ожидания встречи с девушкой. Картины природы созвучны его настроению, ее таинственная красота и жизнетворность словно предвещают что-то неожиданное, больше того - высвечивают мечты и предваряют события:

Как спящая красавица, проснулась

От поцелуя знойного земля,

Проснулась и вздохнула полной грудью,

Глаза протерла, поднялась с постели

В наряде, сотканном из сизой дымки

И легкого прозрачного огня.

В связи с тем, что поэт постоянно наполнял содержание стихов конкретными реалиями суровой жизни в условиях кочевья, то он не ограничивался описанием красоты тундры, которая летом «пестреет полярной совой», «багульник - отрада для взора», и воздух настоян на запахе цветов, а рассказывал и о преодолении человеком летних невзгод. Так, оленеводы в безветренную летнюю погоду с большим трудом справляются с полчищами комаров и мошек, от которых олени порой впадают в бешенство и даже гибнут. Спасают животных неустанно поддерживаемые пастухами дымовые костры и движение по кругу. Об этих напряженных летних днях, когда вдруг «ветер опустит крыла» и мириады комаров «повисают, клубясь, как зловещая мгла», читатель узнает из стихотворения «Летом в тундре» (пер. Я. Козловского).

Привлекая внимание к красоте летней тундры, в которой «по склонам ложбин и впадин на кочках веселый наряд», к ее щедрости — «морошки - хоть век собирай», поэт предупреждает молодых и неопытных, а также всех не знающих северных тайн, о коварстве тундры: «Ходить здесь опасно и трудно. / Всегда нуж- 
но быть начеку! Для нас приготовила тундра / Ловушки на каждом шагу» («Тундра лучится», пер. А. Каныкина).

Топкая болотистая тундра своей обманчивой красотой и щедростью может завлечь в капкан неподготовленного путника.

Осенняя природа в поэзии Лапцуя проникнута не только грустью, но и страхом замирания. Лирический герой стихотворения «Осень» (пер. Н. Грудининой) объясняет свое подавленное настроение не только неудачей на охоте, но и воздействием пейзажа: «Как с покинутого чума одряхлевший старый нюк» ${ }^{10}$, слетают последние лепестки цветов, по-особому светит в светло-синем небе месяц, ветер уносит листья и цветы, приносит прохладу и дожди.

Осеннее море наполнено угрозами, вызывает напряжение и страх. Лирический герой стихотворения «На островке» (пер. Н. Грудининой) глубокой осенью, всматриваясь в «пасмурной воды воронье око», чувствует ее скрытую угрозу.

В отличие от весенних, зимние пейзажи разнообразны по настроению, проникнуты то жизнеутверждающим пафосом, то покоем, то страхом перед разбушевавшейся стихией. Картины зимней тундры реалистичны и точны в полускрытых завуалированных, невидимых неопытному глазу деталях. В наполненной тишиной зимней ночи слышны лишь непонятные редкие звуки, и лишь знаток узнает в них «таинственную ночную жизнь зверья», когда следы мышей во мраке ищут совы, крадется за добычей волк, «согнувшийся в дугу».

Короткий зимний день «мелькнет совой» «там, за холмами, и в сугробы канет», но красива полярная ночь:

Ночь северная в звездном одеянье.

Снегов голубоватое сиянье.

Колеблющийся в сумраке Ямал,

Морозный пар, незримой стужи вал -

То океана мощное дыханье.

(«Полярная ночь», пер. В. Афанасьева)

Солнечный свет полярной ночью заменяют то вспышки северного сияния, то восход луны. Ночное светило для ненцев источник радости для всего живого, особенно в месяце Большой Темноты - декабре, когда дни подобны «зарытым в снег куропаткам», «лохматым теням от снежной упряжки неспешной зимы», жители тундры «по тропам бредут, как олени в постромках». Все живое прячется от многодневных, неистовых снежных ветров: «Кричат в вышине, точно обские чайки, / Спешат аргиши перелетные вьюг, / Как стадо оленье лохматые лайки, / Их гонят кос- 
матые тучи на юг» («При луне», пер. М. Яснова). Но пурга утихает, ветер разгоняет тучи, и открывается сверкающий свет звезд и луны, пробуждающий тундру, подобно солнцу: «Но медная выйдет луна из-за сопки, /И тундра, ослепнув, шарахнется в тень, /И тут же упряжки, въезжая на тропки, /Помчатся, внезапный приветствуя день». Оленьи упряжки отправляются на юг, на ягельные пастбища. Луна становится помощницей большому кочевью.

Эстетически значимым в поэзии Лапцуя становится и безобразное, страшное для жизни человека. Наполнены притягательной силой описания зимней стихии: разъяренно стонет ветер, уносит валы снега, «сугробы по тундре седой гонят ветры, как по морю льдины». В такие дни тундра опасна:

\section{Разъяренная тундра страшна! \\ Вся в движенье. \\ Стеная и воя, \\ Исступленно танцует она. \\ Зарывается в снег все живое.}

(«Север», пер. А. Каныкина)

Пейзажные образы в поэтическом творчестве Лапцуя обретают философскую значимость, позволяют представить действительность в динамической трактовке.

\section{«Цветная сказка северного края»}

Такое яркое определение дал Л. Лапцуй своему самому объемному и значительному произведению - поэме-сказке «Тёр», которая органично сочетает эпическое и лирическое начала. Поэма издана на ненецком и русском языках (переводчик Н. Грудинина).

Творчество - великий связной времен. В поэме Лапцуй, обратившись к собранному им в течение всей жизни фольклору, к материалам этнографов и лингвистов А. П. Пырерки, В. Тонкова, Г. Д. Вербова, Н. М. Терещенко, попытался осмыслить историю своего народа, начиная с ледникового периода.

«Мотивы и сюжеты входят в оборот истории: это формы для выражения нарастающего идеального содержания», — писал Веселовский ${ }^{11}$. В поэму «Тёр» Лапцуй включил мотивы, наиболее характерные для героических ненецких песен - сюдбабц:

- борьба за отнятые в нечестном бою родовые места как долг перед предками;

- поиск невесты для продолжения рода; 
- обретение главным героем богатырской силы, шаманских способностей.

Сюжет поэмы развивается с использованием традиций построения героических песен. Первая глава называется «Под плетенкой» - в бедном чуме, покрытом ковром из травы, женщина прячет мальчика-сироту, родителей которого убили враги.

Перед смертью отец обратился к старшей сестре с просьбой: «Младенца укрой! / Стань сиротинке наставницей мудрой / Должен он выжить, последний в роду». Описание судьбы сироты, которого спасает женщина, чтобы вырос он и стал продолжателем рода - типичное начало некоторых ненецких героических песен. Герой становится богатырем, преследуемый врагами до поры взросления. Им важно, чтобы не стал он таким же сильным и отважным, как отец.

Образ Тёра - собирательный портрет идеального героя, вобравший лучшие черты ненцев: интравертность и сдержанность в проявлении эмоций, острый взгляд и практический ум, милосердие и крепость духа.

Творческий подход Лапцуя к фольклорному наследию обогатил как содержание поэмы, так и многих других его произведений, позволил сохранить устно-поэтическую образную систему. Переводчик поэмы «Тёр» Н. Грудинина отмечала, что поэма насыщена эпитетами и метафорами, фразеологизмами ненецкого фольклора и ей хотелось порой перевести их на язык русских былин ${ }^{12}$.

Определение некоторых подходов к постижению специфики этнического мифологического сознания ненецкого поэта, исторической поэтики его произведений - лишь начало углубленного изучения творчества Лапцуя.

Мифологическое сознание самобытного певца Ямала, преемственность фольклорных и эпических традиций в его творчестве способствовали отражению мифопоэтической картины мира в письменной поэзии. Жизненный путь просветителя народа и творца стали составной частью истории XX века. 


\section{Художественное и ролевое жизнетворчество Юрия Вэллы (Айваседы) (80-е г2. XX-начало XXI в.)}

Ненецкий поэт и прозаик Юрий Вэлла (Айваседа Юрий, 1948-2013) создавал свои произведения, опираясь на национально-исторические художественные традиции устной народной поэзии, развивал их, активно использовал, например, краткие сообщения, характерные для мифа, легенды, активизировал бытовавший у ненцев синкретизм устной поэзии и прозы в одном произведении, внутреннюю диалогичность речи.

Подлинные древние мифологические представления, фольклорные мотивы и даже цельные сказочные сюжеты, а также личные откровения художественно предстали в его своеобычных по форме творениях.

Вэлла формировал национальное самосознание ненцев, воплощая в творчество и в свою жизнь на сломе веков и традиций так называемое ролевое жизнетворчество, совмещая в одном лице литератора, мыслителя, хранящего духовное наследство народа, общественного деятеля и образцового оленевода. Он сам созидал «картину мира», мифологизируя собственную личность и судьбу, воссоздавая уходящие культурные парадигмы.

Юрий Кылевич Айваседа выбрал себе творческий псевдоним Вэлла, подчеркнув тесную связь с отцовским родом. Он родился в семье оленевода Айваседы Кыли (из рода Вэллы) в стойбище на берегу реки Варьеган вблизи селения с тем же названием. В краткой автобиографии, написанной через 55 лет, он расскажет о месте своего рождения: «Между Варьеганом и Новоаганском есть шоссейный мост. Если от моста пройти четыреста метров на северо-запад, можно найти старые, замшелые, но высокие пеньки - здесь было стойбище ненца Айваседы (Вэллы) Кыли». Когда-то крупное стойбище не устояло в годы социальных перемен, было разорено. Сильная духом, не растерявшаяся даже после смерти деда, бабушка Ненги вернулась вместе с детьми на стойбище родителей. В автобиографии выразительно представлено суровое смутное время потери личных оленей и объединения ненцев в колхозы: «Во времена Международного Покраснения, в поисках Колхозного Счастья, полупешком пришли они вместе с родом Айваседы под деревню Варьеган в 1951 году».

Детские годы поэт вспоминает кратко, лишь называя отпечатавшиеся на всю жизнь некоторые события: «Я, как и многие северные дети, прошел через детский сад (помню смерть Сталина), 
прошел через интернат (помню космический полет Первого Спутника и Юрия Гагарина)». Поэт отмечает в автобиографии, что на формирование его характера, пополнение багажа знаний больше всего повлияли люди старшего поколения, в особенности велика заслуга матери отца - бабушки Ненги и отца матери - дедушки Хопли.

Перечисляя вехи образования и писательской деятельности, Айваседа не без иронии, но с гордостью уточняет, что не оставляя охотничьего промысла, «заочно грыз» программу Литературного института им. А. М. Горького и в 1988 году защитил дипломную работу, в основу которой легла вышедшая книга «Вести из стойбища». О своей способности и в дальнейшем совмещать занятия оленеводством с творчеством и общественной деятельностью он написал, что «живет с оленями в бассейне реки Аган» и большое внимание уделяет сбору фольклора, который называет зеркалом культурного уровня своего народа. Для него было важно не просто сохранение фольклора, но и передача потомкам, широкому кругу желающих узнать о его народе «чтобы в это зеркало мог заглянуть любой». В свои 55 лет Вэлла (Айваседа) издал пять книг, подготовил к изданию книжку для ненецких студентов «Сказание о Любви», создал два музея, две школы. В эти же годы он постоянно собирал материал для топонимического словаря под рабочим названием «Река Аган с притоками», который был издан в Ханты-Мансийске в 2010 и 2012 годах. Юрий Вэлла писал на ненецком, хантыйском и русском языках. Первые же публикации появились в периодике в 1979 году - их открыло стихотворение «Первый иней», напечатанное в окружной газете Ханты-Мансийска. Позднее стихи, рассказы, миниатюры печатались в региональных республиканских журналах «Полярная звезда», «Северные просторы», «Сибирские огни», «Урал», «Нева». Большинство из них вошло в его сборники поэтических и прозаических произведений «Вести из стойбища», «Белые крики», «Поговори со мной», который вышел с пометкой «книга для ненецкого студента и для того, кто хотел бы послушать ненецкую душу» (рабочее название было «Сказание о Любви»), «Земля любви: диалоги» и др. Сборник «Ветерок с озера» вышел на русском и английском языках с уточнением «книга-перевертыш»), сборник «Триптихи: Три по семь» вышел в 2001 году на ненецком, русском и французском языках.

Стихи и проза Вэллы переводились не только на английский и французский, но и на венгерский, эстонский, удмуртский языки. 
Юрий Вэлла в «Посвящении читателю», предваряющем его книгу «Белые крики» (Сургут, 1996), поделился выстраданными мыслями, которые его постоянно тревожили: «И вот умолкли Медвежьи Игрища, песни, молитвы, сказки, не слышен или стал редко звучать художественный язык».

Поэт рассказал потенциальному читателю о необычном способе, который придумала его бабушка Ненги для знакомства внуков со старинным фольклором, язык и содержание которого были уже непонятны, незнакомы новому поколению. Ненги традиционно пела сказки, перебивая пересказом-переводом содержания на современный разговорный язык. Она называла свой прием «пешей речью»». Вэлла предположил, что именно этот прием сочетания пения и «пешей речи» и лег в основу его творчества - смеси прозы со стихами. «Трезвые прозаические куски как бы дополняют, разъясняют более эмоциональные поэтические строки. Поэтому, наверное, творческий язык мой - это ненецкохантыйско-русский язык в ненецко-хантыйско-русской форме», - размышлял автор в предисловии. Здесь же он поделился с читателем и тем, как делал фольклорные записи на Медвежьем Игрище казымских ханты. Поскольку ему был знаком лишь сургутский диалект ханты, то он вслушивался в речь, отыскивая знакомые фразы, и записывал «эхо впечатлений с аганских Медвежьих Игрищ», в которых когда-то участвовал.

Многие произведения малой прозаической формы Вэллы написаны в духе устных народных рассказов - зарисовок, являются «невымышленной прозой». Такова миниатюра «Весть с Варьёганского стойбища», где автор-повествователь рассказывает ненецкому оленеводу, который соучаствует в диалоге посредством восклицаний, выражающих то сочувствие, то удивление, то испуг, о том, как Старый Устия из рода Айваседы в начале зимы ехал на оленях по замерзшему озерку и провалился в котлован, заполненный нефтью. Содержание миниатюры-диалога - прямое назидание осваивающим Север нефтяникам, загрязняющим местные болота, озера и реки, зачастую не проявляющим заботы об экологии местного края.

Общественная деятельность Айваседы была постоянно направлена на защиту природы, возрождение культурных ценностей как своего народа, так и народа-соседа ханты. Литератор был членом ассоциации «Спасение Югры», где принимал активное участие, оказывая значительное воздействие на решение вопросов сохранения этнической самобытности, среды обитания, 
уклада жизни, культуры народов. Для сохранения и развития языков и решения насущных проблем он организовал издание газеты «Новая жизнь», где был и редактором, и издателем. Был назван жителями почетным гражданином Нижневартовского района, в основном за создание в поселке Варьёган этнографического парка-музея под открытым небом, к созданию которого, сбору материала приобщил не только район, но и округ. Юрий Айваседа и его жена Елена в 1985 году стали первыми собирателями и хранителями музея. Постепенно музей пополнялся привезенными из стойбищ и селений жилыми и хозяйственными постройками, предназначенными для зимнего и летнего времени года, для оседлого и кочевого образа жизни. На территории современного музея-парка размещены разнообразные священнокультовые сооружения, например, деревянный сруб для хранения медвежьих костей. Представлены многочисленные и разнообразные традиционные средства передвижения северян, такие как нарты, лодка-долбленка (облас), которая изготавливается из цельного дерева кедра или осины.

Юрий Айваседа, убедившись в эффективности работы музея, передал музейное дело в другие руки и стал на собственном примере убеждать ненцев и ханты в перспективности и важности оленеводства. Поселившись вместе со своей семьей в стойбище в ста двадцати километрах от Варьёгана он стал заниматься традиционным для его рода разведением и сохранением оленей.

Литературная и общественная деятельность Вэллы (Айваседы) была отмечена современниками, жителями края: в 2008 году он стал лауреатом Всероссийской литературной премии им. Д. Н. Мамина-Сибиряка; в этом же году награждён нагрудным знаком Думы Ханты-Мансийского автономного округа - Югры «За содействие в развитии законодательства».

Литературные тексты Вэллы, затрагивающие актуальные проблемы жизни народа, - яркое, открытое проявление гражданской позиции. Однако он стремился уйти от прямого назидания, проявить свои идеи через условный характер. В рассказе «Шай-ики», содержащем значительное количество дидактических сентенций, сюжет развивается благодаря дорожным неожиданностям и ставшей судьбоносной непредвиденной встрече. Воплощая идею о сохранении традиционной культуры оленеводства, проявляя заботу об экологии северного края, в частности, лесотундры, эксплицитный автор постоянно погружает читателя в жизнь оленевода, романтизируя быт и традиции, усиливая тем 
самым ностальгию по прошлому. Эксплицитный читатель имеет возможность дискурсивно представить жизненно важные для оленеводов специфические детали исторически сложившегося быта, традиционное отношение к труду, патриархальные и вновь возникшие народные традиции. Он может мысленно увидеть неспокойную, хлопотливую и вместе с тем свободную, наполненную чудесами кочевую жизнь, которая представлена с любовью к северному краю. Просматривается тайное желание Вэллы включить в дискурс современную молодежь - раскрывая символику и значимость традиционного быта и действий, он подсказывает возможность использования их в жизненной практике, подчеркивает важность сохранения традиций для будущих поколений.

Глазами эксплицитного автора представлен традиционный вещный мир семьи оленеводов, живущей в отдалении от поселений. Описание повседневного бытования наглядно свидетельствует о стойкости характера героев, их трудолюбии, умении хранить и воплощать в жизнь полученные от предков навыки и умения в создании материального хозяйственного мира. Особое внимание автора привлекают нарты, расположенные в определенном порядке вокруг чума. Нарты не только средство передвижения, это отражение жизненного уклада семейного стойбища. Каждая из нарт имеет свое название и назначение: мужская повседневная рабочая нарта стоит первой, следующая в ряду «стройная, высокая, аккуратная» нарта для поездки в гости, в посёлок сдавать пушнину или для участия в состязаниях; упряжь её отделана резными костяными украшениями. Повествователь, как видно, хорошо знающий оленеводческий уклад и уважительно к нему относящийся, замечает, что в очертаниях второй нарты он услышал звучание весёлой праздничной песни охотника и запальчивые крики погони оленевода на соревнованиях. Он даже почувствовал, почти «расслышал» голос нарты: «Садись, прокачу!». Рассказчик-повествователь делится своим восприятием стоящих около хозяйского строения женских нарт, каждая из которых отличается и своей красотой, и своим предназначением. Обычную повседневную нарту он лишь называет, определяя ее как устойчивую и «ходкую», а праздничной нарте, поразившей его своей красотой и изяществом, уделяет значительное внимание: «Два передка её - словно пара первых весенних лебедей, тревожно вглядывающаяся в снежную круговерть капризного северного мая. Четырнадцать ножек из прочной берёзы - тонкие, стройные, похожие на ножки молоденьких оленят. Впереди две 
поперечины - выгнутые спины двух соболей. Мне захотелось подойти и погладить их ладонью. Нарта была застелена белой, как туман, оленьей шкурой. На ней должна сидеть только красавица. И тогда, кажется, нарта сама, без оленей, способна сорваться с места и унестись в лесотундру вслед за вьюгой. Попробуй догони!» Эта нарта и размышления о ней становятся для повествователя судьбоносными: он влюбился в дочь хозяина по имени Аринэ - красивую, умелую, трудолюбивую и получил знак ответного чувства при отъезде. Девушка положила на нарту под оленью шкуру сверток, в котором избранный ею мужчина обнаружил качин - поясную сумочку для охотника, расшитую ярким орнаментом под названием «Ветка Молодой Берёзки», несущим весть о любви. Внутрь качина были положены также спички, иголка с ниткой и совсем маленький отрезанный уголок девичьей шали. Порывистое сердце нашего повествователя в ответ на говорящий подарок ликовало: «Ах ты, радость моя, Аринэ, Аринэ! Ах ты, песня моя, Аринэ, Аринэ!».

Фольклор стал неотъемлемой частью содержания рассказа, наполнил его метафорами. Подобно ненецкой песне пребывающего в пути охотника и оленевода звучит описание дороги, радостного ожидания успешной охоты в начале рассказа: «Сосны бежали по обе стороны дороги, как сказочные олени, цепляющие рогами небо. Раздавалась звонкая песня полозьев в морозной стыни. Клубы пара вырывались из ноздрей оленей, и словно белое облако стелилось над дорогой. Звенел в воздухе стук копыт и окрик человека, погоняющего упряжку». Автор бессознательно оценивает места, где проезжает упряжка, как путь мирного сосуществования местных жителей, издревле освоенный хантами и ненцами, наполненный ненецкими и хантыйскими песнями и сказками. Живущий на перепутье дорог оленевод по прозвищу Шай-ики угощает останавливающихся у него гостей не только чаем, но и песнями, сказками. Проезжающим он устраивает интересные состязания для ума, предлагая множество хантыйских и ненецких загадок и головоломок.

Повествователь подчеркивает длительность пути до жилья Шай-ики с помощью использования числа три, означающего в древности у многих народов - «много». «Три ночи мы провели под звёздным небом, бросив под себя на кучу лапника оленьи шкуры и укрывшись поверх кумышей морозным эхом. Шесть раз вспыхивал наш походный костёр, подогревая нам завтрак и ужин. Три раза мы распрягали оленей и три раза вновь запрягали 
их в дорогу. И вот к концу четвёртого дня наши олени почуяли запах стойбища и ускорили шаг».

Юрий Вэлла нередко поэтизировал и трансформировал сюжеты народных сказок, создавая их авторские варианты. Так, на основе известной ненецкой сказки о кукушке он написал свою версию «О чём кукует кукушка», обозначив ее как сказку бабушки Ненги. Дискурсивно выстраивая сюжет как явление современной жизни, давая оценку содержанию мифологической сказки людьми иного времени, автор вводит в традиционный текст новых героев - мальчика Хылу и бабушку Ненги. Он знакомит читателя с присказкой рассказчицы, которой та пробуждала интерес к сказке. «У кого глаза зоркие, у кого уши чуткие, у кого руки ловкие, у кого ноги быстрые? Кто бы сел возле меня, чтоб слушать сказку, которую сказывала давным-давно моя бабушка?» - обращается умелая рассказчица и мудрая воспитательница Ненги и тут же находит слушателя, который оставляет свои дела-игры. Мальчик Хылу, упорно овладевавший мужским мастерством - изготовлением нарточек дедовским ножом, услышав заманчивое предложение бабушки, прерывает свое занятие и бежит к бабушке, чтобы отправиться вместе с ней в мир грез и фантазий. А та с лукавой хитринкой в глазах, представляя свое детство, улыбается своим мыслям и начинает рассказывать сказку, приближая разными приемами содержание ее к реальности, как бы вписывая мальчика в сказочное время: «Давнымдавно, в жаркий день, такой же жаркий, как сегодня, на берегу нашего живуна, только далеко-далеко в верховье, жила в берестяном чуме ленивая девочка с красивой мамой.

- А они пасли оленей?

- У них, конечно, как и у нас, наверное, были олени, но сказка не об этом». Погрузив мальчика в атмосферу доброжелательности и сконцентрировав его внимание, бабушка Ненги рассказывала-пела трагическую историю о невнимательной к матери, непослушной и ленивой девочке, которая не принесла воды матери, занятой шитьем из меха нарядного тянта - одежды для дочери. Мучимая сильной жаждой мать превратилась в кукушку и улетела, несмотря на запоздалые жалобные крики, обещания и слезы дочери. Закончив сказку, бабушка Ненги для проверки воздействия спетого-рассказанного пожаловалась, что ей жарко: «Даже язык к нёбу присыхать стал». Хылу сразу же предложил принести воды, на что старушка в ответ уточнила, чтобы принес он воду не из озера, а из речки - воды «бодрой и живой». Вэлла 
раскрывает процесс народной педагогики ненцев с использованием фольклора, выделяя значимость его для воспитания нравственности у подрастающего поколения. Содержание самой традиционной сказки не только обрамлено приближением к современности, но и расцвечено метафорами, эпитетами, расширенным диалогом героинь сказки, матери и дочери, подробным описанием постепенного превращения женщины в кукушку, наполнено большей трагедийностью.

В благодарность за заботу о нем, за сказки и легенды, которые в детстве в оленеводческом стойбище вечерами пела в чуме и рассказывала бабушка Ненги, поэт посвятил ей лирическое стихотворение, наполненное добротой и благодарностью за духовную пищу.

\section{Бабушке Ненги}

Ты красивее берёзы,

Ты красивее Луны,

Ты желанней Красной Белки ${ }^{13}$,

Руки ласковы твои.

Говорят, ты некрасива -

Голос твой, как скрип сосны...

Но я знаю: словно диво,

Твои сказки входят в сны.

В эссе «Молчание» Вэлла описывает реальное явление чуда, которое происходило с ним иногда в детстве при общении с бабушкой. Это был необъяснимый для него способ влияния бабушки на его видение мира, бессловесная беседа как продолжение только что состоявшегося разговора. Они могли идти берегом реки и вести беседу, но бабушка вдруг останавливалась, опускала «свою корявую, лёгкую, иссушенную руку» на голову мальчика и замолкала. Удивление вызывало то, что она «незримо-неслышно» передавала свои ощущения окружающего, «свое восприятие мира». Эмпатия была столь велика, что мальчик начинал видеть «её глазами нашу залитую солнцем прохладную реку», «слышал её ушами дальнее курлыканье журавлей за болотом», начинал «воспринимать её сердцем наше стойбище и каждый звук, каждый шорох, каждый вздох в нём».

Здесь речь идет, вероятно, не о простой эмпатии, а о возникшей у разных народов еще в глубокой древности вере в возможность непосредственной бессловесной передачи мысли. Как известно, мысль - более высокая форма сознания, чем чувствен- 
ное восприятие. Она результат гармоничной и последовательной деятельности миллионов связанных между собой нервных клеток. Эта связь сложна, вырабатывается в процессе жизненного опыта и поэтому носит индивидуальный характер. Она недостаточно изучена. Можно лишь предположить, что воздействие бабушки на мальчика было столь велико, что произошло мистическое отзеркаливание ее внутренних чувствований и передача мысли.

Влияние народной художественной традиции способствовало формированию присущего Вэлле интуитивно-художественного способа творить. Мифологизированное восприятие ненцами космоса, которое нашло отражение в фольклоре, прослеживается в стихотворении «Разноцветное небо». Раскрывая роль устного народного творчества в рождении произведения, поэт поместил в качестве эпиграфа небольшой отрывок одной из сказок бабушки Ненги, повествующий о том, как охотник распахнул свой темный чум, и в него влетело небо, превратившееся в достаток и счастье. В стихотворении небо ассоциируется с таинственными силами, управляющими миром и человеком. Лирический герой внимательно присматривается к изменениям на небесном своде и на просторах тундры, и глядя в окно дома, порой через цветное стеклышко маленькой дочери, словно ждет от него некоего чуда, способного изменить его жизнь. Небо для героя переполнено многоцветьем: то жёлтое, зелёное, то синее, фиолетовое, то посеребрённое, то позолоченное или сизое. Главное же, что оно живое: «Небо грустно, // Небо нежное, // Полухмурое, // Очень свежее, // Весёлое, // Неласковое, // Красное, // Шутливое, // Нарядное, // Ясное, // Как невеста, прекрасное, // Доброе, // Как дитя, беззащитно-слабое // И богатырски сильное...». Небо может быть приветливым и зовущим. Больше того, небо «может парить над миром // Выше звёзд, // Выше солнц // И галактик». Небо становится для героя и автора символом, вызывающим благоговение, «трансцендентной функцией», по Юнгу, результатом влияния коллективного бессознательного. Фантазии автора свидетельствуют об его эстетическом настроении, восхищении прекрасным, открывают нам нежную и подвижную душу. Бессознательное чудодейственное влияние неба как порождение страстного чаяния, веры и надежды народа изначально было поэтизировано в фольклоре, позднее способствовало развитию ощущений, чувственных способностей поэта, созданию образа разноликого и многоцветного небесного свода в стихах. 
В духе личных народных ненецких песен написано Айваседой стихотворение со вставками прозы «Реликвия». В нем герой Татва из рода Логаны идет берегом озера и поет о своем стойбище, о своем роде и семье, о своих конкретных заботах и делах. Читатель узнает, что живет этот молодой ненец в стойбище на берегу реки, расположенной между двумя озерами в местечке Порсавар. У него есть жена и дочь, которая будет пить глухариный бульон, когда он добудет глухаря, а жена его ощиплет. Эта личная песня прерывается неожиданной находкой - ненец видит каменный топор - реликвию предков. И тогда он сочиняет песню-послание предку, который пользовался этим топором и отправляет его в подарок Татве, чтобы тот «не разучился / Строить себе добротный Дом» и позднее передал умение потомкам.

Оленевод и охотник Айваседа собирал в музее под открытым небом раритеты прежней жизни не только ненцев, но и ханты, при этом сам мастерски владел умением изготавливать нарты и охотничье снаряжение, владел знаниями предков и использовал в жизни, увлекая своим примером, а творец Вэлла привлекал внимание широкого читателя в своих произведениях к издревле бытующему у ненцев мастерству, к высоко развитой наблюдательности. Он сочинял, например, загадки в духе народных представлений, опираясь на фольклорные сравнения и метафоры. При этом он использовал диалог, жанр побасенки, чтобы понять содержание как загадки, так и разгадки мог любой читатель, даже далекий от оленеводческого быта, от жизни ненцев.

«Вот моя загадка:

— Что бы это такое было: карась — а у него семь ребер?

- Лодка.

- Лодка для одиночки.

- Так и скажи, что облас!

- У правильного обласа всегда семь поперечин.

- Так оно и есть!»

Следует отметить, что для повседневной речи ненцев свойственно использование приема загадок, склонность к таинственности, наиболее часто проявляющаяся при общении с гостями и с детьми. Диалог загадок Юрия Вэллы подобен подслушанному в обычной жизни разговору то взрослых людей между собой, то их разговору с детьми.

«Вот моя загадка:

— Что бы это такое было: кочуя, они ставят чумы на стоянки предков? 
- Копыта.

- Когда олень шагает, ставит задние копыта туда же, где прошли передние.

- След в след?

— Точно так!»

Постоянно убеждаемся, что сохранение древних традиций, забота о природе родного края были среди важнейших задач, которые решал общественный деятель Айваседа и отразил в творчестве Юрий Вэлла. К сожалению, порой Айваседе недоставало рационального ограничения и законченности в организации экологической деятельности, а Вэлле - в создании произведений. Отсутствие в некоторых его произведениях критического интеллектуализма можно объяснить, опираясь на психологические исследования, результатом активно развитых чувственных ощущений, обостренного восприятия внешних воздействий, способностей интуитивно угадывать «смутно осознанные побуждения» (К. Юнг).

Вэлле было присуще тонкое чувство жизни природы. Так, антропологически представленная природа в размышлениях о Родине - эссе «Вся Родина» - способна вызвать сочувствие, привлечь внимание и заботу о ней. Перед читателем возникает мифсказка о тундровом крае, о его одушевленной, наполненной мистицизмом природе. Возможно, именно мистицизм как мирочувствование потребовал создания мифа для своего выражения, чтобы с его помощью выразить специфическое восприятие окружающего мира. Лирический герой, уподобляя себя олененку, сравнивая себя с ним - «как тот олененок» вспоминает «повёрнутый к солнцу тундровый бугор, говорливый ручей по оврагу и огромную чёрную яму, заросшую травой и тальником-ерником» и представляет себе картины образования и этого тундрового бугра, и этой черной ямы. Изначально он видит лежащий веками на поверхности тундры огромный камень, вокруг которого протекает активная жизнь: растения рассматривают его и пытаются вести с ним игру, так, «румяная морошка, бойко подбоченясь и наклонив голову» хочет определить его высоту, а стебель травыпырея стремится дотянуться до камня, чтобы пощекотать его холодный бок. Птицы тоже не оставляют камень своим вниманием: птенец трясогузки, важно вышагивая по камню, оставляет метки, чтобы весной, вернувшись на родину, не перепутать с другим; птенчик не замечает парящего над «мирной тундрой» орла, зорко высматривающего добычу. Но трагедию для окружающего лирический герой видит не в охоте орла, а в том, что, вероятно, 
однажды камень перевернули, и надломленный стебель травыпырея «закричал», раздавленный глаз морошки «разлился слезой», а трясогузка, не найдя своих меток, улетела «умирать на чужбину». Так на месте лежавшего камня вытаяла в вечной мерзлоте яма, пустота которой и зияет незаживающей раной в воспоминаниях то ли лирического героя, то ли эксплицитного автора.

Владевший хантыйским языком, собиравший фольклор не только ненцев, но и хантов, Вэлла обрабатывал его художественно и помещал в книги как на хантыйском, так и на русском языках. Наполнен назиданием молодому поколению беречь природу отрывок из хантыйского предания о сибирских реках Оби и ее притоке Аган. В нем Обь-Старик советует молоденькой еще Аган-дочери оберегать свои берега, раскрывая тесную взаимосвязь всего живущего на земле: «Они есть, чтоб Белый Ягель копил силу для оленьего взгляда, чтоб Красная Белка выкармливала в Кедровом Дупле свой выводок, чтоб Иглою Владеющая Женщина всегда шила для своих дочерей-сыновей Белые Кисы и Белые Рукавицы, чтоб под лыжами Удачливого Юноши всегда было бодрое скольжение».

В произведениях Вэллы животный мир поэтизирован, наполнен деталями, раскрывающими мифологическое восприятие зверей, птиц, рыб. Этому способствовали полевые записи Айваседы-исследователя, которые он постоянно вел, тщательно вникая в слова и действия присутствующих во время обрядов. Свои записи «медвежьего игрища» у казымских хантов он предваряет признанием в том, что поскольку язык казымских хантов отличается от известного ему аганского диалекта, он записывал лишь знакомые слова и фразы, но при этом не упускал из виду, как они произносились, какими позами и жестами сопровождались. В духе охотничьих заклятий звучат строки его четверостишия, исполненного горечи и надежды:

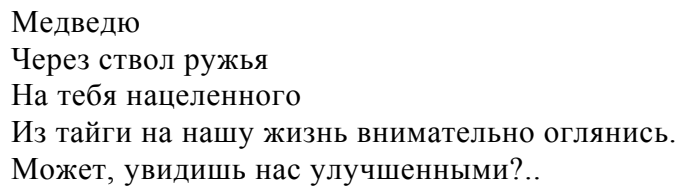

Юрий Вэлла в триптихе «Размышления после медвежьего игрища» пытался раскрыть тайну медвежьего духа, его поведения, способности спать в берлоге длительное время, обходиться без воды и еды. Главное, что волновало поэта - замирание жизни и 
ее оживление. В игровой форме Вэлла ведет диалог с Наварром Скоттом Момадэем ${ }^{14}$ - американским индейцем из племени кайова, который приехал в гости в Сибирь. После совместного посещения праздника медведя американский индеец и сибирский лесной ненец ведут беседу о сложности судеб народов, о встрече как оживлении, воскрешении душ, которое ассоциируется у Вэллы с выходом медведя из берлоги. М. Скотт Наварр в предисловии к своему роману «Диалоги медведя с Богом» написал: «В Западной Сибири мне показали атрибуты хантыйского медвежьего праздника - шкуру и медвежью голову, будто маску иного мира, медвежьи лапы, сани, на которых медведя вносят в его дом, его чум. Стоя рядом с этими вещами, я ощутил их силу. В их присутствии я постиг тайну медвежьего духа - как происходит, что Медведь пляшет, пребывая на грани жизни и смерти, свободно минуя их пределы».

В поэзии и прозе хантов мифологема медведя является одной из самых выразительных. Хантыйский поэт Микуль Шульгин в стихотворении «Медвежья пляска» воспевает азарт танца.

В круговом танце солирующий герой стихотворения Шульгина как бы устремляется вверх, на седьмое небо, к верховному божеству Торуму, сыном которого, согласно мифам, был медведь. Во время медвежьего праздника - представления, продолжающегося традиционно в течение нескольких дней, участники исполняют до трехсот «номеров»: песен, танцев, пантомим, кукольных представлений.

Мифы о происхождении медведя, являющиеся составной частью медвежьего праздника, исполняются в песенной форме, что было характерно для представления хантами любых мифов, используемых в ритуальной обстановке, когда во время сакральных действий предполагалось присутствие воспеваемых сущностей (зверей, птиц, духов и др.). Известно, что согласно традиции один и тот же сюжет мифа ханты могли исполнять и в песенной форме, и прозаической, и в форме ритмизированной прозы.

Танец с пением на самых ранних этапах истории народов, по мнению этнолога и фольклориста Г. Василевич ${ }^{15}$, был «охотничьей пантомимой» и есть много общего между этой пантомимой и соревнованиями охотников, в которых выявлялись сила, ловкость, быстрая сообразительность, смелость. Описывая в «Историко-этнографических очерках» круговой танец эвенков ёхорьё, фольклористка отметила, что изначально это был своеобразный «хоровод животных и птиц». 
О медвежьих праздниках у эвенков, которые сопровождали добычу медведя, об отношении этого народа к сакральному зверю, опираясь на сообщения сказителей, исследователь М. Г. Воскобойников писал, объясняя, почему важно соблюдать ритуалы: «Хотя медведь и убит, но он единственный из зверей, кто может разбираться в человеческих сказках, песнях и играх, и недостойно в дни церемоний, связанных с охотой на медведя, рассказывать о нем сказки» ${ }^{16}$.

Медведь в мифах, легендах и сказках народов Севера - символ разумного и сильного, сакрального зверя. Отражающая мифологическое миросозерцание литература позволяет приблизиться к разгадке, как этими народами устанавливалось в далеком прошлом онтологическое единство человека и природы. Человек видел во всем природном зооморфное или антропоморфное, отождествлял себя с природными явлениями, очеловечивал природу. Семантическая наполненность мифологем в литературе напрямую связана с их соотнесенностью с мифами и устной народной поэзией. Эстетика мифа - имагинативное бытие. Миф отражает также и то, как человек в прошлом далеком бытии в своем воображении, сливаясь с природным миром, с животными, стремился овладеть их силой, укреплял таким образом свою надежду на осуществимость желаемого, развивал свои волю и дух при поддержке песен и заклинаний.

В стихотворении эвенкийского поэта Николая Калитина «Сэбярин» лирический герой - охотник приглашает в гости желающего научиться охотничьему ремеслу, предлагает попробовать традиционную еду из медвежьего сала, сердца и печени сэбярин. «Пищей сильных людей сэбярин в нашем крае считают», - утверждает герой. Он объясняет: «с медвежьею силой в тайгу нас потянет тотчас, / По сугробам глубоким пойдем, по тропинкам звериным, / И улыбка удачи в тайге засияет для нас». Как видим, медведь у эвенков - тотемный ритуальный зверь, как и у многих других народов Севера.

По житейским установкам, по своему характеру герои повести-сказки эвенкийского прозаика Галины Кэптукэ «Умусликэн и его друзья» медведица и медвежонок близки человеку. Медведица Амака заботливая, внимательная, добрая мать. Она не сразу соглашается с желанием своего медвежонка Тэмбе спасти оставленного женщиной на дереве ребенка, представителя «поперечноглазных-двуногих». Амака как мудрая мать поняла, что малыша спрятали среди веток на дереве, чтобы спасти. Медведица говорит 
Тэмбе, что человеческое дитя нельзя ни съесть, ни сделать игрушкой, поскольку это «грешно». И товарищем он стать не может, потому что, когда вырастет, то сможет победить и медведя. Медвежонок оказывается добрым и упрямым, отказывается слезать с дерева до тех пор, пока Амака не привела прародительницу домашних оленей эвенков - Энгны, чтобы та накормила ребенка волшебным молоком и спасла человеческое дитя. Все звери и птицы приняли активное участие в судьбе Умусликэна, который научился понимать их язык, стал лучшим другом медвежонка Тэмбе.

Создавая образы зверей и птиц, Кэптукэ учла их повадки, представления о них эвенков, взятые из фольклора и жизненного опыта. Так, в самый ответственный момент сражения Умусликэна с разбойником Сэлэргуном за освобождение из плена сородичей герою помогает, придает силу клык друга-медвежонка. Медвежья сила, которая стала «прибавляться с каждой минутой», сделала героя победителем в неравной схватке.

На основе многочисленных наскальных изображений, петроглифов, сравнения их с забайкальскими, археолог Окладников в книге «Открытие Сибири» ${ }^{17}$ выделил художественно выполненные рисунки медведя и лося, борющихся за владычество. Согласно рисункам, жители тайги устраивали ежегодные весенние торжества с целью возрождения зверей и умножения охотничьей добычи. Как известно из мифов и фольклорного материала, этнографических материалов и реальной жизни, во время празднеств, при исполнении ритуалов перед охотой и после нее эвенки, как и другие северные народы, пытаясь воздействовать на сверхъестественные силы, на окружающий мир, использовали магические формулы, заклинания, обращение к духам зверей, к идолам-покровителям.

В стихотворении эвенкийского поэта Алитета Немтушкина «Обращение к идолу Бэллэю после неудачной охоты» лирический герой, став пасынком судьбы на охоте, всю вину за неудачу во время охоты возложил на Бэллэя, воплощающего дух охоты. Вспоминая его заслуги во время охоты, охотник напоминает и о том, что за эту поддержку он перед охотой отдал ему «на платье» сакральное медвежье ухо.

Юрий Вэлла активизировал и в творчестве, и в жизни бытовавшие в недавнем прошлом, но, к сожалению, долгие годы осуждаемые представителями былой власти традиции и обычаи. Так, он предпринимал попытки собирать северян для участия в Медвежьих Игрищах, называя их мифом о происхождении жизни на Земле, о взаимоотношении человека с миром. Ритуал предполага- 
ет участие всех присутствующих, на нем не должно быть посторонних. Ритуал в поэзии и прозе северных народов приоткрывает тайны самобытной, сакральной жизни в мифе, внутри его текста, и в реальной действительности, приобщает к их истории.

Шопенгаэур, например, высоко ценил вклад творцов поэтического изображения жизни народа в историю, считая, что оно (изображение) содержит «объективность», поскольку оно либо наполнено открытым живым созерцанием, личным настроением в лирической поэзии, либо завуалировано в других «родах поэзии», где изображаемое или совершенно отделено от изображающего, или «изображающий в большей или меньшей степени скрывается за изображаемым и, наконец, совсем исчезает» ${ }^{18}$.

Юрий Вэлла придавал большое значение биографии и автобиографии творцов. Кроме краткой автобиографии он написал близкий по жанру к эссе «Автопортрет», свидетельствующий о стремлении автора постичь основы человеческой психики, приоткрыть специфику творческого процесса писателей и поэтов, понять глубины человеческого бытия. Он дискурсивно, вступая в диалог с эксплицитными читателями, дает в «Автопортрете» совет исследователям творчества, критикам рассматривать и определять творческие личности, отделяя их «творческое лицо» от их «бытового лица». Он приводит примеры своих ответов на часто задаваемые ему вопросы о жизни и творчестве. Мансийскому поэту Ювану Шесталову и хантыйскому прозаику Еремею Айпину советует при создании творческого портрета писателя не искать с ним личных встреч, а читать его произведения, знакомиться с отзывами о его творчестве и сравнивать их со своим личным восприятием, со своими личными эмоциями, полученными от прочитанного. Вэлла объясняет свой совет тем, что личное общение порой может исказить творческий облик писателя, творца, его автопортрет, поскольку писатель, как и любой человек, может быть в разных ситуациях иным. Это зависит от личного расположения духа, от настроения окружающих, «даже от политических течений и от природных аномалий». Попав при личной встрече под плохое настроение, можно всю жизнь иметь искаженное представление о творчестве талантливого творца.

Мнение Юрия Вэллы звучит как бы в унисон с утверждением Шопенгауэра, что автобиографии и биографии будут ценными и значимыми для постижения истории «человеческого движения», если жизнь отдельной личности в узком кругу будет изображена верно. Не вызывает сомнения, что именно биографии и автобиографии творцов во многом способствуют исторической реконст- 
рукции литературных текстов, а также воздействуют на восприятие читателя, позволяют совершенствовать герменевтическую интерпретацию. Больше того, сравнивая значимость для познания человечества «в его внутренней сущности, тождественной во всех проявлениях и в развитии» материалов историков и художественных произведений, а также биографий и автобиографий, Шопенгауэр в своей работе «Мир как воля и представление» отдавал предпочтение не историкам. Он уподобил историка человеку, «который безо всякого знания математики посредством измерения случайно найденных фигур исследует их отношения, отчего эти эмпирические выводы страдают ошибками начерченных фигур; напротив, поэт подобен математику, который конструирует эти отношения a priori, в чистом созерцании, и выражает их не такими, как они действительно начертаны в данной фигуре» ${ }^{19}$.

Творчество Юрия Вэллы убеждает, что он был широко мыслящим, стремившимся к глубинному познанию действительности, истории, литературы и искусства. Необычны, философичны его размышления о творчестве хантыйского художника Геннадия Райшева, галерея-мастерская которого находится в ХантыМансийске. В основу его творений, как и у Вэллы, заложены традиции народного искусства обских угров, демонстрирующие также родство с мифологией других народов Югры.

Исходным моментом написания эссе послужили Вэлле взятые им в качестве эпиграфа слова английского писателя, автора откровенного автобиографического романа «Путь всякой плоти» Сэмюэля Батлера: «Любое человеческое творение, будь то литература, музыка или живопись, - это всегда автопортрет». На примере воздействия на него графической работы Райшева «Егор Большой» писатель подчеркивает свою приверженность этой идее Батлера.

С графической работой Райшева «Егор Большой» Вэлла познакомился раньше, чем с самим художником и другими его картинами, в частности, с автопортретом. Но ни беседы с художником, ни внешнее сходство художника с его автопортретом, не смогли заслонить, сгладить первое представление о художнике, которое возникло при знакомстве с картиной «Егор Большой». Он даже сочинил для себя «несуществующую работу Г. Райшева “Егор Маленький”». Эта работа часто вспоминалась им, вставала перед глазами поэта. Он видел мальчика, плывущего на обласке (лодке) по речкам Агану, Югану, его окружал сказочный мир, и этот волшебный мир вызывал у поэта ощущение, что он более жизненный, чем тот, что придумал художник. 
В эссе «Автопортрет» Вэлла пытался представить свой творческий образ, сравнить его с человеческим обликом. Он предполагал, что, написав книги «Вести из стойбища», «Белые крики», «Азбука оленевода» и «Поговори со мной» в раннем возрасте, должен был видеть себя на автопортрете таковым: это «молодой ненец, почти что юн и поэтому искренен, порой до наивности, до юношеского максимализма». После же создания книг «Триптихи», «Путем Хозяйки Агана» и в поэме на два голоса с Т. Юргенсон «Охота на лебедей», ему показалось, что «незримый автор стал уже более зрелым, хотя выше среднего возраста всё-таки не перевалил». Каково же было его удивление, когда представленный им мысленно автопортрет вовсе не совпал с фотоиллюстрацией на последней странице «Азбуки оленевода», написанной в молодом возрасте. Предлагая читателю взглянуть на нее, он обращает внимание на глаза, определяет их как хитрые кошачьи, глаза умудренного старца, постигшего мировоззрение и детей, и взрослых. Лик же на фотографии, по его мнению, больше подходит главе оленеводческого рода, который одет в выжженную солнцем и побитую дождями и ветрами малицу, мужскую меховую одежду.

Этот неузнанный Вэллой собственный портрет наводит его на мысль, что автор ранних произведений не был юнцом, по крайней мере, лишь казался им, а на самом деле, возможно, это был и тогда «мудрый старец, сумевший спрятаться за юного шалунишку Котофея». Этот самоанализ - яркое свидетельство пытливости, живой динамичности, устремленности к познанию ненецкого творца.

В создании своих произведений Вэлла часто опирался на представление внешней и внутренней речи героев, использовал авторские приглашения к размышлениям и участию в дискуссии. Контактные и визуальные диалоги героев, персонифицированных именами или таинственно зашифрованных обозначением одной буквой, например Н., наполнены у Вэллы как разговорной непринужденностью, так и интеллектуально-насыщенными, образно-богатыми монологическими размышлениями. Внешняя и внутренняя речь героев в диалогах Вэллы пересекаются, взаимодействуют, но обретают порой совершенно иной эмоциональный и смысловой характер. Так в написанном на ненецком языке и переведенном автором на русский язык произведении «Поговори со мной» параллельно использованы внешняя и внутренняя речь героев. Мифологема Слово стала действующим лицом, о чем как бы предупреждает автор в начале: «Изрекали Старцы издревле: "Мысленное Слово, произнесенное с уверенностью, как слово, 
произнесенное вслух!"» Далее Вэлла описывает случайную, ставшую волнующей и незабываемой, встречу в тундре двух молодых людей на оленьих упряжках. Они знакомятся, задают друг другу привычные вопросы о семье и занятиях. Девушка едет в город, где учится в институте, а юноша - в оленеводческое стадо, где заботится об оленях. Краткий разговор завершается внешне спокойным прощанием. Все эмоции героев, их затаенные желания автор переносит во взволнованную, наполненную зарождающимся любовным трепетом внутреннюю речь. Оказывается, уже с первого взгляда в душах молодых людей зазвучали наполненные трепетом жизнелюбивые слова: «С протянутой ладони твоей скатилось мысленное Слово:

- Ax! Я, как зазевавшаяся на солнцепеке лиса, так близко увидевшая ружье охотника! Не слишком-то тревожь мое сердце! Хочу бежать от твоего взгляда, да руки-ноги мои онемели!

А в душе твоей отразившаяся мысль его такова:

- Взгляд твой затронул мою душу! Словно от спячки проснулся я! Словно рыба на истоке реки обсохшая, сердце мое испуганно хвостом о песок бьется! Вот и какую-то ерунду сказал! Одновременно хочу прикоснуться к тебе или убежать!

Это была ваша первая мысленная встреча».

Начатый при встрече внутренний телепатический диалог молодых людей продолжился и после встречи. Она шептала ему слова признания из лабиринта города, и он слышал их на пастбище, отвечал ей, предлагая не сдерживать своего желания и петь.

Мифологическое слово-песня ненцев, обладавшее мистическими способностями перелетать с места на место, нередко используемое в сказках и произведениях других ненецких поэтов, именуемое порой песней Мынико и превращающееся в реальные сущности, трансформировано Вэллой, стало творческим приемом при создании сцен признания в любви, раскрытии тайных связей между влюбленными.

Поэтические размышления Айваседы о любви отражают специфическое восприятие мира, в котором жизнь природы и космоса олицетворены, они присутствуют постоянно как знаки поддержки или искушений, порой же - гнева и вражды. О своих чувствах ненцы, согласно мифам и фольклору, намекают, сообщают знаками - девушка может подарить понравившемуся юноше приготовленный заранее своими руками символический подарок, например, украшенную орнаментом охотничью сумочку, которую юноша обнаруживает у себя уже в пути, после встречи. 
«Спасибо, что ты нашла путь своим знакам // К моему сердцу», - пишет лирический герой Вэллы в стихотворении «Белая ночь». В ответ на «трепетный восторг», переполняющий героиню Н., приводит Вэлла сон Талё-Охотника с пометкой «Из сказки Бабушки-Ненги». В нем герой в облике Белого олененка, бегая по берегу озера, наслаждается любовью Матери-оленихи, которую сравнивает с «безграничным, огромным, совершенным миром».

В творчестве ненецкого поэта звучат мотивы пробуждения любви человека разных видов, это и родительская любовь, и любовь к родной земле, к отечеству, а также часто определяющая судьбу человека - любовь мужчины и женщины. Он увидел в реальной жизни тенденцию замирания, охлаждения этого чувства. Знаменательно, что Вэллу, творца на рубеже двадцатого и двадцать первого веков, начала нового столетия и тысячелетия, волновали вопросы любви, мнение о которой перекликалось с размышлениями философов и творениями русских поэтов начала XX века, в которых звучала тоска о потере этого чувства. Они отмечали важность синкретизма в определении любви - опоры на этику, эстетику, психологию, видели в любви источник вдохновения, связывали ее с духовной культурой человека, с поиском нравственных ценностей. Философ Иван Ильин считал отсутствие любви причиной духовного кризиса в начале прошлого века: «Да, в людях мало любви. Они исключили ее из своего культурного акта, из науки, из веры, из искусства, из этики, из политики и воспитания. И вследствие этого человечество вступило в духовный кризис, невиданный по своей глубине и по своему размаху. Нельзя нам без любви. Без нее мы обречены со всею нашею культурою. В ней надежда и спасение» ${ }^{20}$. Другой представитель творческого мира столетней давности Дмитрий Мережковский писал: «И хочу, но не в силах любить я людей», устремлялся к природе, но приходил к выводу: «А меж тем не с волной и не с ветром мне жить, // И мне страшно всю жизнь не любить никого».

Юрий Вэлла, хорошо знавший творения русских поэтов и философов «серебряного века», в своем творчестве стремился подобно предшественникам разгадать связь этого таинственного и сложного чувства с духовностью, с судьбами мира. Он жил в постоянном поиске гармонии, ощущал душевную тревогу за человечество, о чем свидетельствуют и беседы с сородичем о разноликом грядущем конце света, изложенные в разделе «Апокалипсис» (книга «Земля любви»). Он пребывал в размышлениях о судьбе народа, в постоянном поиске себя в этом мире, что под- 
тверждают как его жизненные установки, общественная деятельность, забота о сохранении духовно-материальных традиций ненцев, языка, об экологии края, так и творчество. В его напряженных диалогах на самые разнообразные жизнетворческие темы нашла свое место и одна из актуальных и сложных для понимания и определения - тема любви. Для раскрытия авторских представлений о ней обратимся к сборнику «Земля любви», изданному в Ханты-Мансийске в 2009 году, который состоит из трех частей. Первая часть обозначена как создание двух авторов: «Н. и Вэлла» и названа «Этот совершенный мир (о тебе и обо мне)», содержит пометки: «диалог», «Монастырь-на-Волге| Стойбище-на-Тюйтяхе», «2005-2009». Перед второй частью, где автором обозначен Ю. Вэлла, названной «Апокалипсис» с пометками «былички», «беседы с сородичем», указаны место и год написания «Стойбище-на-Тюйтяхе| Варьеган», «2008». Третью часть предваряет титул: «Юрий Вэлла — оленевод. Татьяна Юргенсон журналист. Охота на лебедей (диалог). 9-15 сентября 2001».

Эти таинственные указания об авторстве, месте и времени создания метрических стихов и прозы, название изданной при жизни автора книги на русском и английском языках (книгаперевертыш) - загадка автора, которую еще предстоит разгадать исследователям творчества.

Концентрируя внимание на теме любви в творчестве Вэллы, рассмотрим содержание первой части книги «Земля любви». Судя по пометкам самого автора, эта часть под названием «Этот совершенный мир» содержит подборку как изданного ранее, например, из книги «Вести из стойбища», «Белые крики», «Ветерок с озера», так и из рукописей, песен оленеводов, сказок бабушки Ненги. Вся подборка представлена автором в форме то затуманенного, то ясного, то многозначительного, то однозначного, то жесткого в изложении мнения, то успокаивающего диалога двух личностей — неизвестной лирической героини «Н.»и лирического героя «Вэлла». Так гласят подписи под стихотворными и прозаическими текстами необычного диалога. Он пронизан размышлениями об этом разноликом мире, о месте и роли человека в нем, о чувственном восприятии окружающего и о главном феномене человеческих отношений - о любви. В своеобразную фабульную основу длительного, возможно, письменного, чаще же всего телепатического диалога заложено развитие чувственной и духовной связи, возникшей между мужчиной и женщиной во время пребывания на море-океане, вдали от их постоянного местопребывания. 
Он живет на севере, занимается оленеводством, имеет, вероятно, семью. Она - жительница иного края, находится там, «где город плечи кутает шалью балтийских туманов». Есть намек и на плод любви: «В зыбке уютной спит моя девочка»; в подарок женщина шлет «сладкий вздох счастливого ребенка».

Судя по всему, каждый из участников диалога находится в ситуации зависимости от обстоятельств, обременен обязательствами, о которых предпочитает не говорить, но которые не позволяют им быть вместе. И это привносит трагическую ноту в симфонию пульсирующих чувств. Герои связаны нежными чувствами, и это позволяет им почти одновременно думать об одном и том же, вести мысленную беседу, в которой соучаствует общее для них небо. Диалог начинает Н. словами «Усталый день простился с солнцем. / Уснуло небо. / Погрустим». В ответ раздаются ободряющие слова Вэллы: «Но утром небо встрепенулось // От криков улетающих гусей.../ И тонкий лед по краю озера сверкал». Женщина периодически впадает в отчаяние, у нее появляется желание разорвать виртуальную связь. Применяя женскую уловку, она предлагает ему уйти из ее жизни: «Любовь стучит в мой дом. // Но засов в дверях заржавел. // Уходи, напрасно сердце тревожишь». Мужчина же предлагает ей прислушаться к своему сердцу, успокаивает словами о предстоящей весне. В беседе возникают обидные для каждого из них ситуации из прошлого: вот мужчина покинул ее ради другой, а это Н. не отвечает на его звонки, и ему приходится за «шуткой обидной и злой» прятать свою любовь.

Женщина периодически делится мыслями об уходе из жизни, чтобы избавиться от непосильной земной любви и печали, о своей надежде на то, что их сменит более радостное потустороннее чувство: «К заводи тихой свой утлый челнок направляю. // Плещется парус, и злобные волны пугают. // Но там, куда спешит мое сердце, обрету /Любовь, //Навеки печаль забуду». Свои терзания она облекает в слова о поисках покоя: «В серых одеждах тоскует зима. //Остаться нельзя и невозможно уйти. // Где покой обрету?»

Загадочная Н. успокаивается лишь благодаря получаемым вестям из стойбища о повседневных оленеводческих занятиях любимого, о той радости, с которой воспринимает он заботы каждого дня и общение с оленями и природой, о его размышлениях о Земле Любви.

Лирический герой Вэлла переносит захватившее его широкое глубинное чувство любви к женщине на родной край, на родину: 
Я мечтаю, чтобы мы - люди

Научились говорить о Родине,

Не произнося этого слова...

Я мечтаю, чтобы мы - люди

Научились говорить о Любви,

Не клянясь в любви...

Воспринимая любовь как глубинное скрытое чувство, поэт пытался постичь ее суть. В диалог двух влюбленных героев включает разнообразные судьбоносные перипетии их отношений, размышления о волнующих проблемах.

Для Юрия Вэллы, как и для других ненецких творцов, Лапцуя, например, свойственно было искание жанра. Он, как и Лапцуй, обращался к дидактической поэзии, которую поэт и переводчик С. Е. Раич в «Рассуждениях о дидактической поэзии» называл догматической ${ }^{21}$, ссылаясь на Платона. Раич подчеркивал сходство дидактика с оратором и существенную значимость воздействия на читателя «мифологии древних», тех истин, что возникли в былые времена, получены были благодаря глубоким наблюдениям и проверены опытом: «подобно оратору, поражающему противника доводами, всегда постепенными, дидактик от начал простых, обыкновенных, переходит к исследованиям сложным, утонченным, почерпнутым из глубоких наблюдений, и нечувствительно возвышает до них читателя. Так ветер, касаясь Эоловой арфы, начинает прелюдиею, которая, кажется, мало обещает слуху; но, усиливая дыхание, он вливает в нее душу и по временам извлекает из струны ее красноречивую мелодию, потрясающую весь состав нашего сердца». Раич мечтал о новом расцвете «догматической» поэзии и ее преобразователях. Возможно, мы вправе отметить, что ненецкие поэты, как и творцы других народов Севера, развивали и продолжают вносить свой вклад в преобразование дидактической, догматической поэзии, используя мифологию древних. Немало стихотворных дидактических наставлений в поэзии Лапцуя молодым охотникам и оленеводам, выстроенных на традиционных установках:

Я весь век хотел бы быть

Верным древнему завету:

«Оставляя в жизни мету,

Ты природы не обидь.

Если тундре нанесешь

Ты обиду или рану

Или порчу океану,

Сам в себя ты всадишь нож». 
Наставления Юрия Вэллы в «Азбуке оленевода» также в основе своей содержат проверенные вековым опытом жизненные правила и нравственные каноны:

Оленя вырастить, приручить -

Надо три года.

Для того, чтоб утратить, запустить, растерять стадо Достаточно три дня.

Дидактическая поэзия Вэллы и других ненецких поэтов Леонида Лапцуя, Прокопия Явтысыя, Василия Ледкова - является трансформацией, кратким изложением поучений, наставлений, обобщающих мыслей на разные темы, запечатленных в мифах и фольклоре. Они изложены в духе народных ненецких песен, пословиц, загадок. Афористические короткие стихи названных ненецких поэтов специфичны по форме, отличаются порой глубоким психологизмом, напряженностью, как бы провоцируют читателя на какое-то ответное действие, предполагают некий поступок или вступление в диалог.

Своеобразный характер произведений Юрия Вэллы, в которых поэзия и проза не разделяются резкой чертой, а как бы перетекают друг в друга, продолжая и развивая смысловую линию или сюжет, необычные размер стихов, ритмика прозы явились предметом для дискуссий. Исследователи фольклора, литературные критики, литературоведы (среди которых А. Ващенко, М. Мельников, Е. Лагунова, Ю. Хазанкович, и др.) не раз пытались определить жанровую характеристику творчества Вэллы, особенности стихосложения. Однако многое в определениях требует поиска убедительных доказательств. Так, предваряя цикл стихов и прозы Юрия Вэллы «Вести из моего стойбища» обращением к читателю журнала «Сибирские огни» (1988 г.), М. Мельников предложил ему самому (читателю) попытаться определить жанровую принадлежность художественной формы ненецкого творца и изложил собственную точку зрения: «Это не эссе, не коллаж, тем более не рассказ, не поэма, а нечто самобытное, идущее от ненецкого фольклоpa, своеобразный “слепок” народной души, по-детски светлой, наивной, ранимой и по-стариковски мудрой одновременно» ${ }^{22}$.

В предисловии к книге Юрия Вэллы «Ветерок с озера» А. Ващенко отметил, что еще до личного знакомства узнал о поэте как авторе своеобразных стихов, написанных верлибром, необычном для российских традиций, зато в духе устной поэтической традиции коренных народов, имея в виду ненцев и ханты. Он назвал 
прозу Вэллы прозаическими миниатюрами «полуфольклорного характера», отметил, что граница между поэзией и прозой в его творчестве довольно условна: «Лирика его “выходит" на эпос, а проза глубоко лирична - они сильно дополняют друг друга». Он считал, что творчество Вэллы представляет собой «редкое сочетание устных традиций и литературных инноваций» ${ }^{23}$. Сам автор определил содержание книги «Ветерок с озера» - «проза и все, что напоминает прозу».

Не вызывает сомнения, что генезис синкретизма поэзии и прозы в произведениях стихотворного размера Юрия Вэллы кроется в народной поэтической традиции ненцев, бытовавшей до нашего времени, сохранившейся и в современном фольклорном творчестве.

По мнению ряда ученых (А. Потебня, Ю. Тынянов и др.), поэзия была изначально у всех народов песенной, благодаря же прозаическим вставкам стала синкретичной, а позднее - разделилась на стихотворную и прозаическую. Об историческом изменении непростых отношений между поэзией и прозой писал Юрий Тынянов в работе «Поэтика. История литературы». Исследователь обозначил и их дифференциацию: «Мы молчаливо считаем метрическую прозу - прозой и неметрический верлибр стихом» ${ }^{24}$. Возникает предположение, что поэзия Вэллы-Айваседы, в основном, представляет собой неметрический верлибр.

В стихосложении Юрия Вэллы, кроме фольклорного влияния, просматривается тесное взаимодействие поэта с японской литературой. Свои афористичные короткие стихи ненецкий поэт почти не рифмовал, последовав примеру создателей японских танка и хокку. Как известно, укороченные стихи - афоризмы у японцев возникли еще в седьмом и восьмом веках на основе народных песен и заменили в литературе длинные эпические и героические песни фольклора, а также длинные стихи нагаута - авторские стихи. Танка - пятистишие и хокку - трехстишие, являвшееся начальными строфами танки, в японской поэзии современности пользуются большой популярностью. Возможно также, что Вэллу вдохновил впечатляющий по своему жизнеутверждению творческий пример таджикско-персидского поэта Омара Хайяма, который взяв за основу греческую эпиграмму, создал рубаи (четверостишия), покорившие читателей во всем мире. Больше того, многие поэты и народные певцы стали слагать новые рубаи.

Избрав форму завершенных формулировок, Юрий Вэлла проявил свою отзывчивость мифологизированного сознания на про- 
исходящее в жизни людей и изменения в природе. Его лирические стихи в духе танка и хокку передают жизнь и природу в круговороте времен года, что подтверждают диалоги лирических героев Н. и Вэллы:

Зима потеряла свою мантию.

Хандрит и плачет уныло.

Осень давно ушла, оставив скучные улицы.

Пью ароматный чай.

Наслажденье...

(4 ноября 2005 г.)

И словно услышанное и увиденное издалека признание вызывает издалека ответ:

Чай свой сдобрю морошкой.

Двор заснеженный весь.

Ступлю на тропу за оленями.

И в лес...

Афористично, сжато выражает Айваседа возникшие под влиянием легкокрылого свежего чувства импульсы. Их недосказанность, подобно трехстрофным хокку, будит мысль читателя, оставляя простор для фантазий.

Лесная фея посетила мой дом.

Запах цветов и горькой листвы остался надолго.

Буду зимой видеть теплые сны

(запись 1 ноября 2005 г.)

Поэту удается сказать многое малым количеством слов, передать чувства героини Н.:

День, что ушел, не простившись,

Унес ожидания трепет.

Вновь обрету надежду в тонком дыхании утра.

Трепетные переживания героини, олицетворение автором неразрывной связи природы и человека создают умиротворенное, радужное настроение, погружают в размышления о фантастическом таинственном чувстве любви.

Вэлла мог бы повторить вслед за О. Мандельштамом, которому тоже были близки тонкое ощущение краткости, недолговечности, красоты в японских хокку: «Я получил блаженное наследство, чужих певцов блуждающие сны».

Знаковая образность насыщает краткие словесные творения Вэллы, соединяет мирское и духовное, природное и человеческое. 
Содержательный смысл этой образности впитал национальное своеобразие мифогенного восприятия мира, первоосновы ненецкой народной культуры, специфические формы народной мудрости.

Вэлла увидел в миниатюрном хокку близкое ему по духу «схватывание текущей, подвижной неповторимости». Согласно определению Н. К. Гея, хокку - это не «“описание” природы и не ее "переживание", не фрагментарная "картина" мира, а его онтологическое присутствие. Данность мира, осмысленная как целое существование и даже как целостность его существования» ${ }^{25}$.

Постоянно впитывая опыт предков как из реальной жизни, так и из сокровищницы устного народного творчества, трансформируя идеи и формы поэтического искусства ненцев и ханты, Юрий Вэлла (Айваседа) стремился вписаться в мировую поэзию, опираясь, в частности, на русскую, японскую литературы, занять свое место в цепи преемственности. Интертекстуальные связи поэта, так же как и взаимодействие, взаимовлияние других творцов литератур Севера с литературным миром предполагают организацию расширенной герменевтической интерпретации.

На рубеже веков и третьего тысячелетия Юрий Вэлла представил читателю своеобразный и еще достаточно таинственный мир северян. Его творчество, а также оценка культуры и цивилизации, прозвучавшие в одном из интервью, приоткрывают специфику мировидения ненцев: «Литинститут дал мне интеллект, дал главное - понимание ценности стойбищной цивилизации. Я литинститутовскими глазами оглянулся на стойбищную жизнь и стал понимать, что это цивилизация, а не как раньше говорили - первобытно-общинный строй, от которого надо уходить, переводить коренных жителей на оседлый образ жизни» ${ }^{26}$.

Айваседа-Вэлла, так порой он подписывал свои произведения, был активен в решении проблем сохранения языка и культуры, народных традиций и промыслов коренных жителей своего края - ненцев и ханты, своим творчеством внес значительный вклад в развитие литературы и культуры.

\footnotetext{
$\overline{1}$ Аверинцев С. С. Поэтика ранневизантийской литературы. М., 1997. C. 7.

${ }^{2}$ Там же. С. 7.
} 
${ }^{3}$ Хомич Л. В. в 1966 г. записала в поселке Ныда легенду: «Было большое стойбище. Пришли войска врагов и всех перебили. Остались лишь сестра с маленьким братом. Сестра спрятала брата в чуме в оттаявшее место под костром и прикрыла железным листом (толью)». Она предполагает, что именно отсюда и возникло название рода Лапцуй (Лабсуй, Лапсуй), означающее буквально «плоский, прихлопнутый» - Хомич Л. В. Проблемы этногенеза и этнической истории ненцев. Л., 1975.

${ }^{4}$ Эккерман И. П. Разговоры с Гёте в последние годы его жизни. М., 1981.

5 Самойлова Е. Н. Певец Ямала // Просвещение на Крайнем Севере. № 25. Л., 1992.

${ }^{6}$ Пензер - бубен, старинный ненецкий музыкальный инструмент.

7 Лапцуй Л. Пензер звучит над тундрой // Сияние Севера. М., 1987.

${ }^{8}$ В 1839 г. старшинам удалось схватить Ваули Ненянга (Пиеттомина) и передать его в руки царской администрации. По решению суда Ваули Ненянг был отправлен на поселение в Сургут. Однако ему удалось бежать и уже весной 1840 г. он возглавил новое движение ненецкой бедноты в низовьях Таза и Пура с довольно четкой программой: сокращение ясака наполовину, снижение цен на муку и другие товары при повышении цен на пушнину. К Ваули Ненянгу присоединились надымские и ямальские ненцы, нижнеобские ханты. Схваченный с помощью провокации в Обдорске, Ваули был отправлен сначала в Березов, затем в Тобольск и предан военному суду, который приговорил его к ссылке в каторжные работы. Генерал-губернатор Западной Сибири утвердил приговор и предписал отправить Ваули для отбывания каторжных работ в Восточную Сибирь.

${ }^{9}$ Ненянг — по-ненецки означает комар.

${ }^{10}$ Нюк - оленьи шкуры для покрытия чума.

11 Веселовский А. Н. Поэтика (1897-1906) // Собр. сочинений. Т. 2. Вып. 1. СПб., 1913. С. 12.

12 Грудинина Н. От переводчика // Лапцуй Л. Тёр. Поэма-сказка. М., 1984. C. 6.

${ }^{13}$ Красная Белка - символ пушного зверя, удачной охотничьей добычи.

${ }^{14}$ Наварр Скотт Момадэй (Navarre Scott Momaday) родился 27 февраля 1934 г. - индейский писатель. В 1968 г. его роман «House Made of Dawn» («Дом, из рассвета сотворенный») был удостоен Пулитцеровской премии. Роман «Диалоги медведя с Богом» приоткрывает тайны «медвежьего духа».

15 Исторический фольклор эвенков. Сказания и предания. Запись текстов, перевод и комментарии Г. М. Василевич. М., 1966.

${ }^{16}$ Воскобойников М. Г. Бытовая сказка эвенков // Фольклор народов Севера СССР. Сборник научных трудов. Л.,1980. С. 29.

${ }_{17}^{17}$ Окладников А. П. Открытие Сибири. М.: Молодая гвардия, 1979. С. 75.

${ }_{18}$ Шопенгауэр А. Собрание сочинений: В 6 т. Т. 1: Мир как воля и представление: Т. 1 / Пер. с нем. М.: ТЕРРА, 1999. С. 217.

${ }^{19}$ Там же. С. 215. 
${ }^{20}$ Ильин И. Без любви // Русский эрос, или Философия любви в России. C. 397.

${ }^{21}$ Раич С. Е. Рассуждение о дидактической поэзии // Вестник Европы. 1822. № 7. C. 199.

22 Мельников М. Обращение к читателю // Сибирские огни. 1988.

${ }^{23}$ Ващенко А. В. Живун (слово о Юрии Вэлле и его книге) // Вэлла Ю. Ветерок с озера. Проза и все, что напоминает прозу. Ханты-Мансийск: Полиграфист, 2008. С. 6-8.

24 Тынянов Ю. Н. Поэтика. История литературы. Кино. М., 1977. С. 276.

25 Гей Н. К. Категории художественности и метахудожественности в литературе. Тезисы // Литературоведение как проблема. Труды научного совета «Наука о литературе в контексте наук о культуре». Памяти Александра Викторовича Михайлова посвящается. М.: Наследие, 2001. С. 293.

${ }^{26}$ Вэлла - поэт, оленевод, человек. Интервью Ольги Корниенко к 60-летию. «Мир Севера». 2008. Интернет-вариант: http:/jurivella.ru/vanaweb/ index.php/ 2009-07-30-13-15-45/140--2000?format=pdf. 


\section{ЗАКЛЮЧЕНИЕ}

В процессе построения мифопоэтической картины мира в ненецкой литературе эксплицирована связь мироощущения и миропонимания как авторов, так и героев с мифологическими представлениями, которые затрагивают все волнующие человека коренные вопросы мироздания, метафизическую, трансцендентную и онтологическую связь с животным миром, окружающей природой. «Представление о кровном родстве всех форм жизни это, по-видимому, общая предпосылка мифологического мышления», - предполагал Э. Кассирер ${ }^{1}$.

Мифопоэтика в литературе отражает и активизирует имевшие традицию метафизические представления ненцев о свойствах бытия и познания - о первообразах, включающих логос, о пространственно-временных представлениях, о числовом коде, о верованиях.

В литературе ненцев «коренные понятия человечества» как составляющая мифов, мифов-сказок так же, как и у чукчей, ханты, манси, долган, эвенков, актуализированы на уровне сюжетно-композиционных сближений, явных или скрытых цитат, реминисценций, аллюзий, сознательных вариаций и других форм влияния.

Произведения ненецких творцов можно назвать культурным артефактом, пришедшим на смену мифам. Народно-мифологический пласт заложен в основу их творческих кодов, художественного мира. Писатели стали современными толкователями мифов, фольклорных образов, поскольку приняли и адаптировали их, трансформируя и воссоздавая первообразы (архетипы). Обладая трансцендентной силой возвращения и воздействия, первообразы, а также рожденные на их основе мифы и первичные представления о пространстве и времени, числах, окружающей природе, космосе реализуют свои значения в виде различных элементов текста: сюжетов, образов, предметных и предикативных мотивов. 
Мифологические представления о мире в культурах разных народов имеют сходство, что подтверждает и осуществленное в работе сопоставление элементов мифопоэтики произведений нескольких народов Севера с использованием приемов сравнительно-исторического метода. В работе рассмотрены прозаические произведения чукотского писателя Юрия Рытхэу, ханты Еремея Айпина, стихи долганского поэта Огдо Аксеновой, ханты Микуля Шульгина, эвенка Алитета Немтушкина.

Намечен один из путей для последующих поисков в разработке темы. Антрополог Дж. Фрэзер в «Золотой ветви», используя сравнение разных мифов и обрядов для интерпретации смысла мифологических представлений, писал, что исследования в области древнейшей истории человечества обнаружили, что при множестве поверхностных различий первые философские системы, выработанные человеческим разумом, сходны в своих существенных чертах. Синхронность психических восприятий разных людей и событий во всех краях земли, в культурах никогда не пересекавшихся между собой народов наводит психологов, философов, астрологов на мысль о влиянии космических ритмов на коллективные подсознательные процессы.

Постигая литературы народов Севера с помощью осознания первообразов, мифологии, мы погружаемся в особый мировоззренческий мир, наполненный специфическими символами, жизнеутверждающими образами. Оппозиции свет и тьма, добро и зло, радость и горе, поддержка и равнодушие, красота и уродство и другие пронизывают восприятие космоса, земных стихий. Обращение к первообразам, идеям, которые стали из незримого порождения сознания видимыми образами, образцами поведения, - путь не только к открытию новых смыслов в художественных текстах, но и к постижению мировидения героев, к прояснению их поступков и поведения в разнообразных жизненных ситуациях.

При определении пространства, явленного в текстах, способов его художественного преобразования отмечено, что оно выступает в разных ипостасях и существенно как для организации действий и поступков героев, так и для их характеристики, для отражения специфики мировидения.

Обращение к необратимому и «устойчивому» времени устных и письменных творений ненцев помогает более глубокому пониманию конкретных произведений эпических жанров и типологии многих художественных явлений в литературных произве- 
дениях. Вплетая в ткань произведений прошлое время из жизни народа или жизни героев, ненецкие литераторы стремятся использовать его благотворное влияние на судьбу героев, найти в прошлом энергию для преодоления трудностей, закалить волю, укрепить характер.

Известный специалист по философским проблемам естествознания С. И. Вавилов считал, что обращение к представлениям первобытного человека, к миру поэтов, в чем-то подражающих ему, поможет найти возможные истоки научных гипотез о пространстве и времени. «Он удивителен и сказочен; в этом мире между явлениями природы смело перекидываются мосты - связи, о которых иной раз наука еще не подозревает. В отдельных случаях эти связи угадываются верно, иногда в корне ошибочны и просто нелепы, но всегда они заслуживают внимания, так как эти ошибки нередко помогают понять истину» ${ }^{2}$.

В процессе анализа текстов удалось убедиться, что ненецкие писатели и поэты создали художественные образы своих произведений с активным привлечением представителей животного мира. Зоонимы, зооморфизмы являются в них важной составной частью содержания и, соответственно, отражением мифологического сознания как героев, так и самих авторов.

Приоткрыть глубинные духовно-психологические перемены в мироощущении ненцев и чукчей, в эволюции их сознания позволило обращение к числовому символизму в художественных произведениях.

Трансцендентное, присутствующее в жизненном опыте как у ненецких писателей, так и у творцов других литератур народов Севера, героев их произведений, осуществляет себя чаще всего не опознаваясь в качестве такового, реализуясь то в роли имманентных мифологических персонажей, то в камланиях и заклинаниях шаманов, то в традиционных обрядах, ритуалах, а также в процессе коллективного и индивидуального взаимодействия с окружающей природой.

«Тексты жизни» и тексты поэтические у ненцев зачастую не имеют жестких границ. Мифологизация явлений исторической, общественной и личной жизни, а также мира природы и мира вещей - отличительная особенность их поэтики. Соединяя, сопрягая мифологическое с обыденностью реальной действительности, творцы создают сознательно или бессознательно новые мифы, развивают письменную культуру, своеобычную литературу, выступают в роли просветителей. 
Заложены в природе человека мифологические представления глубоко, и потому так действенно выступают в роли культурного фактора, становятся мощным духовным оружием. С поддержкой мифа, опираясь на мифопоэтические структуры сознания, можно приобщить человека к высшим образцам красоты и добра, но существует и опасность манипулирования его поведением, создав утопический миф, определив в качестве жизненно важных ограничивающие свободу и закабаляющие ритуалы.

В связи с тем, что универсум шаманства недостаточно изучен, чтобы обоснованно объяснять трансперсональные техники и ритуалы шаманских действий и результатов, исследование процесса отражения его в литературе - один из путей осуществления постижения специфики шаманизма. Можно предположить, что литературоведение окажет влияние на дальнейшее развитие, по крайней мере, даст методологические «подсказки» естественнонаучным типам знаний.

Процесс исследования мифопоэтики, этнопоэтики национальных литератур, в том числе литератур народов Севера, как свидетельствует анализ литературоведческих работ разных лет, сопряжен с разработкой подходов, методологии. В работе К. Султанова «От дома к миру» выделены два методологических подхода, наметившихся в последние годы. Один из них - «позиционирует себя как индифферентный к логике художественной трансформации, ограниченный дежурными фразами о роли и значении фольклора». Другой - как избыточное внимание к этнографическому, «этнокультурной рефлексии». По мнению К. Султанова, «этнокультурные реалии должны прочитываться в их содержательной структурообразующей и смыслоподражающей функциональности и, следовательно, этнокультурное своеобразие предстанет как своеобразие художественное, как явление поэтики» ${ }^{3}$.

В работе Ю. Г. Хазанкович «Фольклорно-эпические традиции в прозе малочисленных народов Севера» ${ }^{4}$ представлен своеобычный вариант выявления специфики взаимодействия мифологии и фольклора с литературой, рассматриваются вопросы их трансформации и адаптации в прозаических произведениях. Ею также описано, как осуществлялся поиск решения данной проблемы предшественниками - Р. Бикмухаметовым, В. Комановским, А. Пошатаевой и др.

Как нам представляется, перспективным может в будущем стать для исследователей акцент не на поэтике этнического, а на этническом как явлении поэтики. Этнологический аспект иссле- 
дований литератур народов Севера сопряжен с распознаванием смысла не только текста, но и самих традиций, обычаев, бытования и психологии, истолкованием тайного прошлого и скрытого настоящего в духовной жизни своеобычных северных этносов. Существенным для литературоведов является то, что синергетика культуры этноса - дискурсивный механизм в постижении семантики художественного текста, его этнопоэтики.

Как теоретическое достижение проведенной нами работы можно определить использованный комплексный подход к построению мифопоэтической модели мира в ненецкой литературе, который эксплицирует смысловую глубину связи трансцендентного с жизненным миром, позволяет проявить роль мифологем и бинарных оппозиций, мифологических повествовательных схем, лежащих в основе разнообразных художественных структур. Кроме того, теоретически значимо то, что в процессе работы определены приемы, которые позволили пролить свет на проблему постижения национального мировоззренческого мира, наполненного специфическими символами, жизнеутверждающими образами.

Оживление мифологических символов, воскрешение их к новой жизни древнегреческий историк Фукидид называл «вечным воскресением человеческой памяти». Вдохнув прошлое в новую жизнь, трансформировав его, соединяя с настоящим, ненецкие поэты и прозаики, как и творцы других народов Севера, реанимируют, активизируют, укрепляют память не только своего народа, но и оказывают благотворное воздействие на память человечества.

Условно-метафорически ненецких поэтов и прозаиков можно назвать не только ретрансляторами из древности в современность художественного типа мировоззрения, творцами мифопоэтической картины мира, участниками ролевого мифотворчества современности, но и культурологами, историками, создающими этническую историю, наполняющими культурологию, развивающими культурно-историческую память.

${ }_{1}^{1}$ Кассирер Э. Опыт о человеке // Кассирер Э. Избранное. М., 1988. С. 536.

${ }^{2}$ Вавилов С. И. Глаз и Солнце. М., 1976. С. 3.

${ }^{3}$ Султанов К. К. От дома к миру. М.: Наука, 2007. С. 20.

${ }^{4}$ Хазанкович Ю. Г. Фольклорно-эпические традиции в прозе малочисленных народов Севера / Монография. Отв. ред. Ч. Г. Гусейнов. Новосибирск: Изд-во СО РАН, 2009. 


\section{УКАЗАТЕЛЬ ИМЕН}

A

Аверинцев С.С. 255, 308

Айпин Е.Д. 78, 81, 82, 86, 96, 100, 101, 108, 113, $172,297,312$

Аксенова O.Е. 108, 312

Алиева А.И. 5

Андреев Д.А. 16, 181, 184

Аристотель 91

Афанасьев А.Н. 5, 137

Афанасьев В. 266, 274, 279

Б

Банников К.Л. 252

Барт Ролан 5, 9, 10, 16

Батлер Сэмюэль 298

Бахтин М.М. 5, 10, 15, 18, $88,89,177,189,190$, 191, 214, 253, 296

Башляр Гастон 8, 16

Беликов Л.В. 5, 97, 138

Бигуаа В.А. 2

Бикмухаметов Р. 314

Блок А.А. 185, 214

Богораз-Тан В.Г. 5, 97, 217, 221

Борев Ю.Б. 5, 10, 17, 88

Борисов А.А. 106, 138

Буслаев Ф.И. 137

B

Вавилов С.И. 313, 315
Вавлё (Ваули Пиеттомин) 267, 309

Вальгиргин М.В. 134

Василевич Г. 295

Ващенко А.В. 211, 212, 214, 305,309

Веккер Л.М. 24

Вербов Г.Д. 179, 184, 245, 280

Веселовский А.Н. 77, 90, 280, 309

Воскобойников М.Г. 5, 295

Выготский Л.С. 144

Вылка Н.С. 3, 152-154, 213

Вылка Н.С. (Тыко Вылка) 3, 48, 104, 105, 266

Вэлла Ю.К. (Айваседа) 4, $15,142,160,163,165$, 169, 170, 183, 188, 197, 199, 207, 211-213, 253, 254, 256, 283-308

$\Gamma$

Галифакс Джон 241, 252

Гампер Г. С. 276

Гацак В.M. 5

Гачев Г.Д. 5, 6, 315, 316

Гёте И.-В. 3, 260

Гей Н.К. 308, 310

Гераклит 121

Гладкая Л.Д. 265

Гордиенко Вл. 267 
Грудинина Н.И. 259, 260, $270,273-275,278,279$, 281,309

Гумилев Л.Н. 10, 22, 89

Гусейнов Ч.Г. 315

Д

Долгих Б.О. 178, 184

Достоевский Ф.М. 186

E

Евсюгин А.Д. 252

Ж

Житков Б.М. 152, 184, 233, 252

Жуковский В. 176

3

Замятин Д.Н. 24, 89

Зеленин Д.К. 179, 184

Золотарев А.В. 178, 184

И

Иванов Вяч.В. 5

Иванов С.В. 122, 123. 138

Икскюль Иоганн 168

Ильин И.А. 301, 309

Истомин И.Г. 64, 256, 257

K

Кальвайт Хольгер 252

Калитин Н.Р. 295

Кант Иммануил 18

Каныкин А.Ю. 261, 267, 269, 272, 279

Канюкова Р.И. 266

Кармин А.С. 89

Касаткина Т.А. 123, 138

Кассирер Эрнст 168, 184, 311, 315

Кастрен А.М. 5, 13, 29, 89, $138,187,214,217,221$, 236, 244, 252

Кессиди Ф.К. 23
Козловский Я.А. 263, 273, 278

Комановский Б.Л. 5, 314

Кофман А.Ф. 5

Кравцов П. 264

Куприянова 3.Н. 5, 24, 106, 122,138

Кэптукэ Г.И. 296

Л

Лагунова О.К. 5, 305

Лапцуй Л.В. 3, 14, 15, 33, $34,36,39,41,49,52-56$, $58,60-62,67-71,74,78$, 88, 93, 94, 99, 109-118. $132,141,152,160,162$, 173, 174, 180, 189, 191, 198-202, 206, 209, 215216, 235, 248, 253-281, 305,309

Лар Л.А. 5, 149, 184, 242, 252

Ледков В.Н. 3, 14, 30, 31, $34,35,39-41,45,47,55-$ $62,69-71,79,80,84,98$, $102,105,106,110,112$, $117,126,127,135,136$, 142, 159-171, 174, 180, 191, 198, 199, 208-216, 226, 230-232, 238, 305 Леви-Брюль Л. 5, 11, 24, 46, 90, 91, 138, 190, 237 Леви-Строс К. 5, 9 Лехтисало Т.В. 5 Липперт Ю. 217, 252 Лихачев Д.С. 79, 88, 90 Лосев А.Ф. 23, 89 Лотман Ю.М. 10, 18, 22, 78, 90

M

Малиновский Бронислав 233,252 
Мандельштам Осип 307

Марp Н.Я. 11, 91, 97, 137, 138

Мелетинский Е.М. 5, 7, 16, 118,137

Мережковский Д.С. 301

Мельников М. 395, 309

Минковский Герман 18

Михайлов А.В. 5, 310

Момадэй Наварр Скотт 299, 309

H

Немтушкин А.Н. 296

Ненянг Л.П. 4, 14, 29, 32, $47,51,54,57,58,60,87$, $90,98,128,129,144$, $156,179,215,228,231$, 238, 241, 242, 244, 246

Неркаги А.П. 4, 14, 25, 26,

$37,53,65-67,83-86,103$, $106,107,117,128-130$, $135,145-148,158,166$, $170,172,199,209,211-$ 222, 227, 229, 231, 234

Ницше Фридрих 249

Новик Е.С. 252

Ного И.Ф. 3, 14, 215, 241, 245

Няруй Семен 264

O

Одулок Тэки (Спиридонов Н.И.) 256

Окладников А.П. 5, 13, 139, 184, 296

II

Пифагор 186

Пичков А.И. 4, 30, 168, 261

Полонский В.В. 5

Попов Б. 274

Потебня А.А. 137, 306
Пошатаева А.В. 5, 19, 89, $180,184,314$

Прокофьева Е.Д. 5

Пропп В.Я. 5

Пудовкина Е.О. 260, 277

Пуйко Г.А. 26

Пушкарева Е.Т. 5, 7, 16, 24, $89,124,138,244,252$

Пушкин А.C. 186

Пырерка А.П. 5, 66, 280

$\mathbf{P}$

Раич C.E. 304, 309

Райшев Г.С. 298

Ранг Ф.К. 177, 295

Ругин Р.П. 96, 103, 261

Руссо Жан-Жак 142

Рытхэу Ю.С. 95, 96, 100, $180,192,256,258,312$

C

Самойлова Е.Н. 264, 309

Санги В. 180

Сорокин Л. 271

Старцев Г.А. 72, 90, 231, 252

Стеблин-Каменский М.И. 23

Султанов К.К. 5, 314, 315

Сусой Е.Г. 5, 84, 261, 266

T

Тайлор Э. 89

Тарханов А.С. 105

Тахоля (Коренева Г.О.) 260

Терещенко Н.M. 234, 236, 252, 280

Толстой Л.Н. 186

Топорков А.Л. 137

Топоров В.Н. 10, 13, 21, 89, 139, 184, 186, 214

Трапезников А. 134, 138

Тынянов Ю.Н. 306, 310 
Ф

Фалей В. 275, 277

Флоренский П.А. 47, 90, 122, 134

Фоняков И. 259

Фрай Нортроп 5, 6

Фрейд Зигмунд 133

Фрезер Дж.Дж. 5

Фукидид 315

$\mathbf{X}$

Хазанкович Ю.Г. 5, 305, 314, 315

Харнер Мишель Дж. 252

Хайям Омар 306

Хомич Л.В. 5, 14, 24, 29, $171,175,184,188,214$, $235,244,252,257,298$, 290,308

$\mathbf{Y}$

Чагин А.И. 2

Чехов А.П. 186

II

Шеллинг Ф. 5

Шесталов Ю.Н. 297

Шкавро Л. 258, 259

Шпенглер Освальд 9, 19, 21, 89

Шпет Густав 133, 138

Штернберг Л.Я. 166
Шопенгауэр Артур 297, 309

Шульгин М.И. 175-177, 294-296, 312

Шурц Генрих 217

Щ

Щербакова А.М. 105

Э

Эккерман И.-П. 309

Элиаде Мирча 5, 25, 74, 76, $191,215,252$

Энштейн Альберт 18

Ю

Юганпелик И.А. 3, 14, 59, $110,112,173$

Юнг Карл 5, 7, 8, 16, 32, 33, 90, 91, 137, 138, 195, 208, 214, 292

Юргенсон Т.В. 299, 302

Я

Ядне В.И. 235

Явтысый П.А. 4, 14, 28, 31, $32,35,39-46,51,58,60$, $61,64,73,101,110,112$, $126,131-133,155,163$, 164, 180, 215-218, 224, $225,228,262,305$

Яснов М.Д. 259, 268, 272 , 280 


\section{ОГЛАВЛЕНИЕ}

ВВЕДЕНИЕ

Глава 1. Пространство и время …................................. 17

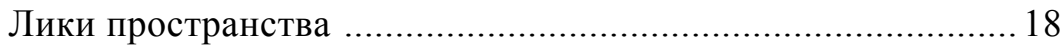

Художественный текст и художественное пространство ......20

О мифопоэтике пространства.............................................. 23

Космология художественного пространства........................228

Концепт круга в мироощущении героев ............................... 36

Тундра - самовластный и покоряемый, реальный и сакральный топос ...................................... 38

Простор как жизнеутверждающий, формирующий личность концепт …............................ 41

Топографическая память и освоение пространства .............4 45

Пейзаж как реальное и метафизическое пространство .........51

Звуки - часть природного пространства и ориентиры ........53

Стойбище и чум как профанное и сакральное пространство ............................................55

Гендерные особенности восприятия пространства...............66

Концепты «время», «вечность», «хронотоп» .......................73 


\section{Глава 2. Первообразы - исток мифопоэтической}

Первичные образы и их перевоплощение

в литературах народов Севера …................................. 92

Логос — первичный вечный образ …............................ 120

Глава 3. Зооморфные мифологические образы ............. 139

Глава 4. Число - код мировидения ненцев .................... 185

Единица. Монада ........................................................... 188

Два. Двойка. Друада ........................................................... 195

Три. Тройка. Триада ........................................................... 199

Четыре. Тетрада ............................................................... 208

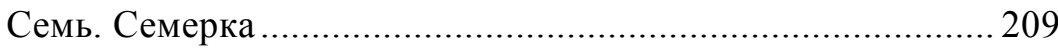

Глава 5. Мифопоэтика и мир шаманов ......................... 215

Культ духа ................................................................ 216

Мистика и эстетика жертвоприношения в литературе ........ 229

Политеизм в литературе ненцев ..................................... 234

Семиотика камлания ................................................... 238

Отражение ритуалов посвящения в шаманы...................... 247

Глава 6. Создатели мифа нового времени ....................... 253

Поэтический миф в XX веке (60-80-е годы). Леонид Лапцуй ......................................................... 254

Жизненно-творческий путь поэта................................... 256

«С рожденья песня входит к нам в сердца»

(О ненецких песнях и стихах Лапцуя) .......................... 262

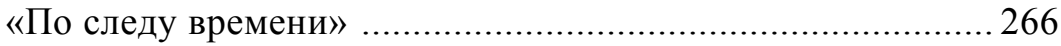


«Стали к земным подбираться кладам» ............................ 268

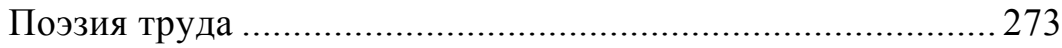

«Земля моей любви» ...................................................... 276

«Цветная сказка северного края» ....................................... 280

Художественное и ролевое жизнетворчество

Юрия Вэллы (Айваседы) (80-е годы XX начало XXI в.) ........................................................ 282

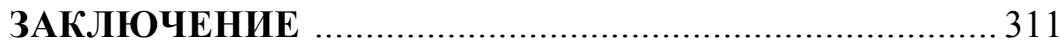

УКАЗАТЕЛЬ ИМЕН ….................................................. 316 


\title{
Научное издание
}

Утверждено к печати Ученым советом

Института мировой литературы им. А.М.Горького РАН

\author{
А.С. Жулева
}

\section{Мифопоэтическая модель мира в ненецкой литературе}

\author{
Корректор \\ Сченснович Е.Н. \\ Оригинал-макет изготовлен \\ Владимирской Л.В.
}

Подписано в печать 15.03.2018 г.

Формат 60х901\%. Бумага офсетная. Гарнитура Таймс.

Печать офсетная. Печ. 20,5 п.л. Тираж 300 экз.

ФЕДЕРАЛЬНОЕ ГОСУДАРСТВЕННОЕ БЮДЖЕТНОЕ УЧРЕЖДЕНИЕ НАУКИ

Институт мировой литературы им. А.М.Горького

Российской академии наук

121069, МОСКВА, УЛ. ПОВАРСКАЯ, Д. 25-А.

Тел.: (495) 690-05-61

Заказ №

Отпечатано в полном соответствии с качеством предоставленных диапозитивов в ППП «Типография “Наука”»

121099, Москва, Шубинский пер., 6

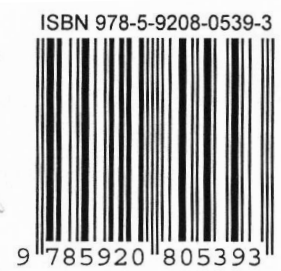


ДЛЯ ЗАМЕТОК 
ДЛЯ ЗАМЕТОК 
ДЛЯ ЗАМЕТОК 
ДЛЯ ЗАМЕТОК 
ДЛЯ ЗАМЕТОК 
В книге представлен новый взгляд на мифологический пласт, заложенный в основу творческих кодов, художественного мира создателей уникальной ненецкой литературы

в XX и в начале XXI веков.

В процессе построения мифопоэтической модели мира в ненецкой литературе осуществлена экспликация символов метафизических представлений народа о свойствах бытия и познания. Выявлено, как обладающие трансцендентной силой возвращения и воздействия первообразы, а также рожденные на их основе мифы и первичные представления о космосе, пространстве и времени, логосе, числах, о животном мире и окружающей природе реализуют свои значения в виде элементов текста: сюжетов, образов, мифологем и бинарных оппозиций. Монография рассчитана на читателей, интересующихся литературой и культурой народов Севера, специалистов-филологов 